FABRício Rodrigo Costa

\title{
A NOMOGÊNESE TRIDIMENSIONAL DO DIREITO À ALIMENTAÇÃO NA CARTA INTERNACIONAL DE DIREITOS HUMANOS DAS NAÇÕES UNIDAS
}

DissertaÇão de Mestrado

Orientadora: Professora dra.Cláudia Perrone Moisés

UNIVERSIDADE de SÃO PAULO

FACULDADE de DIREITO

São Paulo

2014 
FABRício RODRIgo COSTA

\section{A NOMOGÊNESE TRIDIMENSIONAL DO DIREITO À ALIMENTAÇÃO NA CARTA INTERNACIONAL DE DIREITOS HUMANOS DAS NAÇÕES UNIDAS}

Dissertação de Mestrado apresentada à Banca Examinadora, no âmbito do Programa de PósGraduação da Faculdade de Direito da Universidade de São Paulo, como exigência parcial para a obtenção do título de Mestre em Direito Internacional e Comparado, sob orientação da Professora Associada Cláudia Perrone Moisés.

"Versão Corrigida em 28 de Maio de 2015. A versão original, em formato eletrônico (PDF), encontra-se disponível na Comissão de Pós-Graduação (CPG) da Unidade".

\section{UNIVERSIDADE DE SÃO PAULO}

FACULDADE de DIREITO

São Paulo 


\section{FICHA BLIBLIOGRÁFICA}

COSTA, Fabrício Rodrigo. A Nomogênese Tridimensional do Direito à Alimentação na Carta Internacional de Direitos Humanos das Nações Unidas. 2014.300 folhas. Mestrado - Faculdade de Direito, Universidade de São Paulo, São Paulo, 2014.

1.Direito Internacional Público 2.Direito Constitucional 3 Filosofia do Direito 4 Sociologia do Direito 5 Psicologia 6 Relações Internacionais 
COSTA, Fabrício Rodrigo. A Nomogênese Tridimensional do Direito à Alimentação na Carta Internacional de Direitos Humanos das Nações Unidas. 2014. 300 folhas. Mestrado Faculdade de Direito, Universidade de São Paulo, São Paulo, 2014.

\section{RESUMO}

Trata-se de estudo da origem e do desenvolvimento (nomogênese) do direito à alimentação, espécie da categoria dos direitos econômicos, sociais e culturais, com base na teoria tridimensional do direito de Miguel Reale. Nesse sentido, buscou-se na elaboração desse trabalho reconhecer teorias, eventos, fatos, estudos jurídicos, econômicos, psicanalíticos, religiosos, de modo a poder compor, de forma abrangente, o processo de afirmação da justiciabilidade do direito à alimentação.

\section{Palavras Chaves}

nomogênese, tridimensionalismo jurídico concreto, direitos humanos, direitos econômicos, sociais e culturais, direito à alimentação, dignidade humana, segurança alimentar, diplomacia, Organização das Nações Unidas, Carta Internacional de Direitos Humanos, fome, desnutrição,liberalismo, guerra, paz, responsabilidade, consciência, mente. 
COSTA, Fabrício Rodrigo.The Tridimensional Nomogenesis of the Right to Food in the United Nations Internacional Bill of Human Rights. 2014. 300 pages. Master - Faculty of Law, University of São Paulo, São Paulo, 2014

\section{SUMMARY}

This study considers the origin as well as the development of the right to food, a specific economic, social and cultural right, from the methodological perspective of the jurist Miguel Reale and his tridimensional law theory. In this sense, during the elaboration of this present work, we sought to acknowledge theories, events, facts, law, economic, psychoanalytic, and religious studies so that we could arrange the overview of the affirmation process for the justiciabilidade of the right to food.

\section{$\underline{\text { Key Words }}$}

nomogenesis, concrete legal tridimensionalism, human rights, economic, social and cultural rights, right to food, human dignity, food security, diplomacy, United Nations, International Bill of Human Rights, hunger, malnutrition, liberalism, war, peace, accountability, consciousness, mind. 
Agradecemos a todos que, direta ou indiretamente, contribuíram para a realização deste apanhado.

É legal aprender: quando não defendemos nossos direitos, perdemos a dignidade. A dignidade não se negocia.

A Lei está no aroma. 


\section{ÍNDICE}

1.1-Propósitos Dissertativos e a Posição do Tridimensionalismo Jurídico Concreto.................................................................................................................................p.11

1.2-A Nomogênese Tridimensional e $\quad$ o Direito Internacional Público .p.18

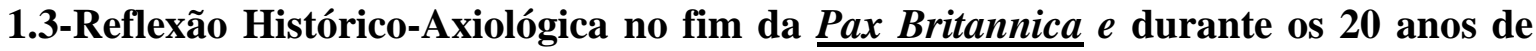
crise (1919-1939). p.26

1.3.1-Anotação Metodológica. p.27

1.4- A Dialética da Complementaridade e o mundo da cultura diplomática. .p.32

1.5-A Pressão Política Internacional pela Carta Internacional de direitos humanos..... ..p.42

1.6.1- A Declaração Universal como modelo jurídico prescritivo .0 .52

1.6.2- O Preâmbulo da Declaração e os direitos morais .0 .55

1.7-As Sete Etapas do Processo de Elaboração da Declaração Universal de Direitos Humanos ou O Rito das Proposições Normativas. .0 .60

1.8-A Participação do Poder no Complexo Factual-Axiológico da Nomogênese do Direito à Alimentação. .p.74

1.9-Nomogênese dos Direitos Humanos: A Segunda Guerra e O Holocausto como Experiências Jurídicas Pré-Categoriais. ..p.82

\begin{tabular}{|c|c|c|c|}
\hline Debate & Histórico-Axiológico & entre & Novos \\
\hline
\end{tabular}

1.11-A Unidade Orgânica da DUDH1948 e Direito ao Pleno Desenvolvimento da Personalidade.............................................................................................................................................p.103

1.12-A Nomogênese dos Direitos Econômicos, Sociais e Culturais como Gênero Normativo do Direito à Alimentação e de outros Direitos Básicos. .109

1.13-A Nomogênese do Direito à Alimentação no Artigo 25 da Declaração Universal dos Direitos Humanos. p.120

2.1-O Comitê de Direitos Econômicos, Sociais e Culturais e seu modelo prescritivo: O Pacto Internacional de Direitos Econômicos Sociais e Culturais. p.140

2.2.1-Rito das Proposições Normativas do PIDESC. p.145

2.2.2- Os Modelos Jurídicos do Tridimensionalismo e o Comitê de Direitos Econômicos, Sociais e Culturais. 
3- O Processo Axiológico-Factual-Normativo dos Direitos Econômicos, Sociais e

4.1-A Semântica Jurídica do Direito à Alimentação e o Modelo Doutrinário da Teoria Tridimensional do Direito. ..$p .162$

4.2-O Modelo Hermenêutico do Direito à Alimentação da Organização das Nações Unidas para a Alimentação e a Agricultura (FAO). .p.166

4.2.1- O Complexo Axiológico da FAO: Origem e Função. p.166

4.3.1-A Cúpula Mundial da Alimentação de 1974 e sua Proposta Normativa de Segurança Alimentar. .p.170

4.3.2.1-A Relação entre Norma e Proposta Normativa. p.172

4.3.2.2-Quem São os Famintos do Século XXI. .p.176

4.4.1-A Cúpula Mundial da Alimentação (1996) p.180

4.4.2-A Declaração de Roma sobre a Segurança Alimentar e seu Plano de Ação. .p.181

5- O Comitê de Direitos Econômicos, Sociais e Culturais e seu Modelo Doutrinário: as Observações Gerais \# 12- E/C.12/1999/5 .p.184

5.1- O Direito à Alimentação e a Dignidade Humana. p.186

5.2-Os Principais Aspectos do Direito à Alimentação. p.187

5.3-As Obrigações dos Estados em relação ao Direito à Alimentação p.190

5.3.1-A Obrigação de Respeitar o Direito à Alimentação. p.191

5.3.2-A Obrigação de Proteger o Direito à Alimentação .p.192

5.3.3-A Obrigação de Satisfazer o Direito à Alimentação. .p.193

5.3.4-A Obrigação de Cooperar e de Prestar Assistência. p.195

5.3.5-A Obrigação de Prover o Mínimo Básico de Subsistência. ..p.196 
6-O Modelo Hermenêutico do Conselho de Direitos Humanos: Relatoria Especial do Direito à Alimentação. .p.199

7-O Modelo Hermenêutico da FAO: As Cúpulas Mundiais da Alimentação $(2002,2009)$ e as Diretrizes Voluntárias (2004). .$p .202$

7.1-A Cúpula Mundial da Alimentação: Cinco Anos Depois (CMA+5-2002)...........p.202

7.2-Diretrizes Voluntárias em Apoio à Realização Progressiva do Direito à Alimentação Adequada em Contexto de Segurança Alimentar Nacional (2004)....p.205

7.3-A Cúpula da Segurança Alimentar (2009) .0 .211

7.3.1-Discurso de Abertura Papal e Análise da Crise Alimentar (2007-2008)........p.212 7.3.2-Objetivos Estratégicos da Declaração de Roma sobre Segurança

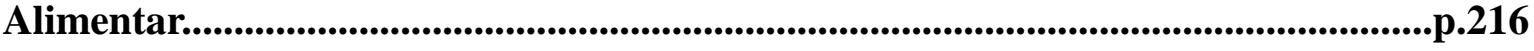

7.3.3-Princípios de Roma e o Comitê sobre Segurança Alimentar (CFS).................p.p.217

8-O Comitê de Direitos Econômicos, Sociais e Culturais e seu Modelo Prescritivo: o Protocolo Facultativo do PIDESC. p.219

8.1-A Conveniência e a Viabilidade do Protocolo como Mecanismo de Denúncia..p.221

8.2-A Vigência do Protocolo e a Justiciabilidade dos Direitos Econômicos, Sociais e Culturais. ..$p .223$

9-Conclusão Fome-Dome-Medo do Mundo da Vida: Direito à Alimentação e a Esquizofrenia do Poder.. .p.226

10-Anexo:Da Evolução do Pensamento de Sigmund Freud durante a Pax Britannica e os 20 anos de crise (1919-1939) ou O Mundo da Vida [Lebenswelt] descobre o instinto de morte. .p.232

11-Bibliografia científico-literária. .p.297 


\section{$\underline{\text { INTRODUCẼO }}$}

O direito à alimentação adequada está consagrado no artigo 25 da Declaração Universal de Direitos Humanos, no artigo 11.1 do Pacto Internacional de Direito Econômicos, Sociais e Culturais, nos artigos 24 e 27 da Convenção sobre os Direitos das Crianças, nos artigos 12 e 24 da Convenção sobre a Eliminação de todas as Formas de Discriminação contra a Mulher. Há também disposições importantes no Direito Internacional Humanitário, estabelecidos principalmente nas quatro Convenções de Genebra de 1949 e nos dois Protocolos Adicionais de 1977.

A presente dissertação de mestrado tem como meta o exame tridimensional da nomogênese do direito à alimentação tão somente na Carta Internacional de Direitos Humanos. Esse sistema jurídico abrange a Declaração Universal de Direitos Humanos, o Pacto Internacional de Direitos Econômicos, Sociais e Culturais e o Pacto Internacional de Direitos Civis e Políticos. Em virtude da multidimensionalidade do direito à alimentação, consequência dos inúmeros desdobramentos semânticos ocorridos desde 1948, buscaremos trazer aos leitores o desenvolvimento nomotético com base na Teoria Tridimensional do Direito e no uso de extensa pesquisa levada a cabo por inúmeros pesquisadores e organizações internacionais.

O conhecimento de direito tão particular quanto o direito à alimentação necessita de uma aculturação científica sistemática, clara e direta. Para tanto, gostaríamos de explicar que o método de citações diretas e longas encontradas ao longo de toda a dissertação, mormente em relação aos raciocínios desenvolvidos por Sigmund Freud, Miguel Reale, Papa Bento, Jean Ziegler, Johannes Morsink, antes de ser um artifício de superficialidade e falta de criatividade autoral, foi uma escolha acadêmica e pedagógica de formulação e apropriação de conceitos teóricos, técnicos e análises, bem como experiências muito particulares, porém não menos universais, com vistas à aculturação mais aprofundada em relação ao objeto de estudo que se encontra no limiar entre o direito doméstico e o direito internacional.

Esperamos atrair a simpatia da leitora e do leitor no decorrer da dissertação, uma vez que se trata mais de um apanhado de inúmeras conjecturas, pensamentos, ações políticas e jurídicas que buscam convergência e rigor técnico quanto ao problema existencial do direito, qual seja o ser humano e o seu lugar na sociedade e na história das Gentes. 


\section{1 - PROPÓSITOS DISSERTATIVOS E A POSIÇÃO DO TRIDIMENSIONALISMO JURÍDIO CONCRETO}

O presente capítulo tem como tema o direito à alimentação e tem como finalidade a compreensão dialética dessa espécie normativa exótica na Declaração Universal de Direitos Humanos (artigo 25) à luz de seu gênero normativo: o artigo 22. Para tanto, pretendemos analisar, tridimensionalmente, o tratamento dado pelo Direito Internacional dos Direitos Humanos às inquietações relativas à nomogênese do direito à alimentação com suporte ${ }^{1}$ nas discussões do artigo 3 da própria Declaração, em razão do princípio usado pelos autores-redatores de unidade orgânica do documento, bem como com base na 'fórmula realena' ${ }^{2}$ :

"Direito não é só norma, como quer Kelsen, Direito não é só fato como rezam os marxistas ou os economistas do Direito, porque Direito não é economia. Direito não é produção econômica, mas envolve a produção econômica e nela interfere; o Direito não é principalmente valor, como pensam os adeptos do Direito Natural tomista, por exemplo, porque o Direito ao mesmo tempo é norma, é fato e é valor. E, pela primeira vez, na introdução do livro Teoria do Direito e do Estado, disse aquilo que generosamente um dos maiores discípulos de Kelsen, Josef Kunz, qualificou de "fórmula realeana": "o Direito é uma integração normativa de fatos segundo valores". O Direito, repito, é uma integração normativa de fatos segundo valores."(grifos nossos)

\footnotetext{
1 - Como hipótese jurídica, seguimos a concepção de suporte segundo o jurista explica textualmente:

<Note-se que correlaciono o suporte com o valor ou o significado, o que não deve ser confundido com a relação entre "suporte fático" e regra de direito, tal como o faz PONTES DE MIRANDA (cf. Tratado de Direito Privado, Rio, 1954, vol I, p. 3 e segs).

A meu ver, fato e valor são enquanto se coimplicam na estrutura do modelo jurídico.

Além disso, toda norma de direito tem um suporte ideal: é a proposição ou juízo de dever ser, por intermédio do qual se objetiva ou se comunica uma significação.

Como se vê, a palavra "suporte", numa compreensão culturalista do Direito, não tem sentido material e físico, como se fora o pedestal de uma estátua ou uma porção de lacre ao receber o timbre>.(gn)

in REALE, Miguel. Teoria Tridimensional do Direito, situação atual, 5 ed. rev. e aum. - São Paulo: Saraiva, 1994, p. 70.

2 idem, p. 119.
} 
Então, elaborei uma imagem ${ }^{3}$ : o Direito não é um queijo ou um doce, se preferirem, com três sabores diversos, correspondentes a três pedaços distintos, de tal maneira que o jurista vem e come a norma, o sociólogo vem e se contenta com o fato, e o filósofo jusnaturalista se perde no mundo do valor. O Direito é uma realidade, digamos assim, trivalente ou, por outras palavras, tridimensional. Ele tem três sabores que não podem ser separados um do outro. O Direito é sempre fato, valor e norma, para quem quer que o estude, havendo apenas variação no ângulo ou prisma de pesquisa. A diferença é, pois, de ordem metodológica, segundo o alvo que se tenha em vista atingir. É o que com acume Aristóteles chamava de "diferença específica", de tal modo que o discurso do jurista vai do fato ao valor e culmina na norma; o discurso do sociólogo vai da norma para o valor e culmina no fato; e, finalmente, nós podemos ir do fato à norma, culminando no valor, que é sempre uma modalidade do valor do justo, objeto próprio da Filosofia do Direito.

${ }^{4} \mathrm{O}$ que entrelaça todas as formas de tridimensionalismo jurídico - das quais Javier Garcia Medina nos oferece magnífico quadro compreensivo - é o propósito comum de alcançar uma visão integral do Direito, superando explicações unilaterais ou setorizadas.

Se algum mérito me cabe, na história de tais estudos, é o de ter insistido no valor objetivo da estrutura essencial da experiência jurídica - que corria o risco de ficar jungida aos quadros de determinadas posições filosóficas - e também (e é este um ponto que posso tranquilamente reivindicar) o de demonstrar a necessidade de superar a colocação da tridimensionalidade em termos genéricos e abstratos, para situá-la de maneira específica e dinâmica, de modo a permitir respostas mais adequadas aos problemas da Ciência do Direito, no concernente, por exemplo, à elaboracão das diferentes espécies de "modelos jurídicos", à sua vigência e eficácia e à sua interpretacão $^{5}$.(gn)

\footnotetext{
${ }^{3}$ ibidem, p. 121.

${ }^{4}$ ibidem, p.147.

${ }^{5}$ ibidem, Prefácio à $1^{\text {a }}$ edição, p. XVIII
} 
À leitora e ao leitor acostumados com a lógica do Direito das Gentes, avisamos, desde já, que pode causar certo espanto o uso da teoria tridimensional direito, se, e somente se, os próprios fundamentos de validade e de existência do Direito Internacional Público forem desconsiderados. A formulação do conceito de Direito Internacional Público (DIP) normalmente parte da concepção que se adote no tocante à natureza da sociedade internacional.

Onde houver sociedade, deverá haver normas voltadas a regular a convivência entre seus membros, dentro da máxima ubi societas, ubi jus ${ }^{6}$. Nesse sentido, o Direito é fenômeno presente também na sociedade internacional, pautando as relações entre seus integrantes e visando, fundamentalmente, a permitir a coexistência, no marco de determinados valores que os próprios atores internacionais decidiram resguardar ${ }^{7}$.

O entendimento clássico é o de que a sociedade internacional é formada apenas por Estados soberanos, noção vinculada à Paz de Vestfália, celebrada no século XVII, quando o ente estatal se estabeleceu como detentor do monopólio da administração da dinâmica das relações internacionais da sociedade que governava. A partir do século $\mathrm{XX}$, as organizações internacionais também passaram a ser vistas como parte da ordem internacional. Formou-se, assim, uma visão do Direito Internacional Público como voltado apenas à regulamentação do relacionamento entre Estados e os organismos internacionais, ou somente dos entes estatais entre si, visto que, na realidade, as próprias organizações internacionais são criadas e compostas por Estados.

A atual dinâmica das relações internacionais vem alterando o entendimento tradicional acerca da composição da sociedade internacional. Com efeito, uma das marcas do mundo de hoje é a participação direta de sujeitos, como empresas e os indivíduos na seara internacional, muitas vezes agindo independentemente de qualquer envolvimento dos Estados. Ao mesmo tempo, o atual contexto internacional veio a tornar evidente a necessidade de que os entes estatais e os organismos internacionais atuem conjuntamente no tocante a temas que têm impacto direto sobre a vida das pessoas e que, por sua complexidade, magnitude e capacidade de gerar efeitos em mais de uma parte do

\footnotetext{
6 "onde há sociedade, há o direito".ARAUJO, Ruy Magalhães de. Expressões Jurídicas Latinas Aplicadas ao Cotidiano Forense.

${ }^{7}$ PORTELA, Paulo Henrique Gonçalves. Direito Internacional Público e Privados, incluindo noções de direitos humanos e de direito comunitário. 3 ed., editora juspodium. p. 45 e sgts
} 
mundo, exigem a cooperação internacional, como os seguintes temas da governança global: a manutenção da paz, a promoção dos direitos humanos, a proteção do meio ambiente e o desenvolvimento nacional. Com isso, o DIP passa a tutelar não só os vínculos estabelecidos entre Estados e organizações internacionais, como também uma ampla gama de questões de interesse direito de outros atores sociais, como os indivíduos.

O reconhecimento da personalidade jurídica do indivíduo no Direito das Gentes é relativamente recente e motivado com base no suporte pioneiro dos direitos humanos na DUDH1948.

Antes de relatar todo o processo decisório que culminou em normatização dos direitos humanos, e, por conseguinte, a nomogênese do direito à alimentação na Carta Internacional de Direitos Humanos, é necessário ler, textualmente, o que Miguel Reale pensa a respeito da experiência jurídica pré-categorial ${ }^{8}$, uma vez que a Segunda Guerra Mundial pode ser caracterizada como um tipo de experiência jurídica pré-categorial aos direitos humanos conforme buscaremos demonstrar à frente.

A "experiência jurídica pré-categorial", isto é, aquela que espontaneamente surge nas relações sociais, como que estabelecendo os pressupostos das normas jurídicas racionalmente esquematizadas desde as costumeiras até as legais, não representa um fato histórico preliminar, que, ao depois, formas jurídicas aperfeiçoadas superam e integram em si: constitui, ao contrário, uma experiência constante, representando também a forma de recepção, pela comunidade ou (permitam-nos o termo) pela "consciência social" das regras racionalmente elaboradas. Pareceme que a tese husserliana de Lebenswelt (mundo da vida) tem fecunda aplicação no estudo quer da gênese das regras jurídicas, quer de suas modificações semânticas.(gn)

\footnotetext{
${ }^{8}$ REALE, Miguel. Teoria Tridimensional do Direito, situação atual, 5 ed. rev. e aum. - São Paulo: Saraiva, 1994, p.102/105
} 
À luz das análises sobre o "mundo da vida"(Lebenswelt), penso ser essencial à plena compreensão do Direito a análise da experiência jurídica pré-categorial, a fim de verificar qual a sua correlação com as instituições jurídicas, as quais representam formas de objetivação da atividade ou da conduta sociais no plano normativo. $O$ que desejo salientar, porém, de maneira especial, é como se opera a mútua influência entre o mundo da vida jurídica espontânea e o mundo do Direito enquanto racionalmente ordenado em um sistema ou em diversos sistemas de regras, conforme se trate de um Estado totalitário ou de um Estado democrático. (gn)

No meu entender, o Direito só se constitui quando determinadas valorações dos fatos sociais culminam numa integração de natureza normativa. Ao contrário do que sustentam os partidários do irracionalismo jurídico, o Direito é impensável sem um momento de racionalização coincidente com seu momento de caráter normativo. A admissão, porém, de forma racional, como elemento essencial ao Direito, não significa que possam ser esquecidos todos os fatores irracionais ou alógicos que estão presentes tanto na gênese das regras jurídicas quanto no processo final e decisivo de sua aplicação aos casos concretos, assim como em sua 'recepção' pelo Lebenswelt. Husserl observa, com razão, que entre as duas formas de experiência, a 'espontânea' e a 'científica', estabelece-se uma recíproca e permanente influência, sendo aquela sempre a base de toda praxis, seja teorética ou extrateorética. (gn) 
Se, de um lado, o "mundo da vida" condiciona as estruturas objetivas das ciências, estas, de outro lado, "afluem ao mundo da vida", de tal modo que, em virtude dessa afluência, ele se converte, em cada caso, em um mundo transformado segundo variáveis condições históricas. Observe-se, outrossim, que essa afluência do racional não desnatura o "mundo da vida", mesmo porque os cientistas (e entre eles os juristas) "são homens entre os homens", participando, assim, das "contingências e necessidades da vida espontânea comum". (gn)

Isto posto, quando um complexo de valores existenciais incide sobre determinadas situações de fato, dando origem a modelos normativos, estes, apesar de sua forma imanente, não se desvinculam do "mundo da vida" que condiciona sempre a experiência jurídica. (gn)

\section{Uma lei, por exemplo, uma vez promulgada} pelo legislador, passa a ter vida própria, liberta das intenções iniciais daqueles que a elaboraram. Ela sofre alterações inevitáveis em sua significação, seja porque sobrevêm mudanças no plano dos fatos (quer ligados à vida espontânea, quer fatos de natureza científica ou tecnológica), ou, então, em virtude de alterações verificadas na tela das valorações. É sobretudo neste domínio que as "intuições valorativas", em curso no mundo da vida, sempre em contínua variação, mas nem sempre de caráter evolutivo ou progressivo, atuam sobre o significado das normas jurídicas objetivadas e em vigor. (gn)

A semântica jurídica, em suma, como teoria das mudanças dos conteúdos significativos das normas de direito, independentemente da inalterabilidade de seu enunciado formal, não se explica apenas em função do caráter expansivo ou elástico próprio dos modelos jurídicos, mas sobretudo em virtude das variações operadas ao nível do Lebenswelt, na qual o Direito afunda as suas raízes. Verifica-se, por conseguinte, que, longe das 
normas jurídicas se modificarem em função de uma força imanente a elas, segundo o esquema do historicismo hegeliano ou marxista, as regras jurídicas se desenvolvem na experiência histórica também como resultado da complementaridade essencial e inseparável existente entre a experiência jurídica pré-categorial e a experiência jurídica cientificamente ordenada, numa contínua interpretação de influências, sem a qual não se abrange o complexo mundo do Direito.(gn)

Por tais motivos, penso que é somente mediante uma dialética aberta, tal como a dialética de complementaridade - a qual não incide no erro de 'identificar' contrários e contraditórios - que nos será possível compreender a experiência jurídica em toda a sua amplitude levando em conta, numa correlação essencial, o que nela se apresenta como experiência espontânea e como experiência reflexa, compondose os modelos do Direito com a vida mesma do Direito.(gn) 


\section{2 - A NOMOGÊNESE TRIDIMENSIONAL E O DIREITO INTERNACIONAL PÚBLICO}

\section{Segundo Miguel Reale ${ }^{9}$,}

o Direito não é um fato que plana na abstração, ou seja, solto no espaço e no tempo, porque também está imerso na vida humana (Lebenswelt), que é um complexo de sentimentos e estimativas. O Direito é uma dimensão da vida humana. O Direito acontece no seio da vida humana. O Direito é algo que está no processo existencial do indivíduo e da coletividade. E assim surgiu uma outra dialética, a dialética existencial do Direito...

Aqui, peço licença a vocês para mostrar uma outra expressão dialética num jogo de perspectivas, que vou expressar com o seguinte símbolo:

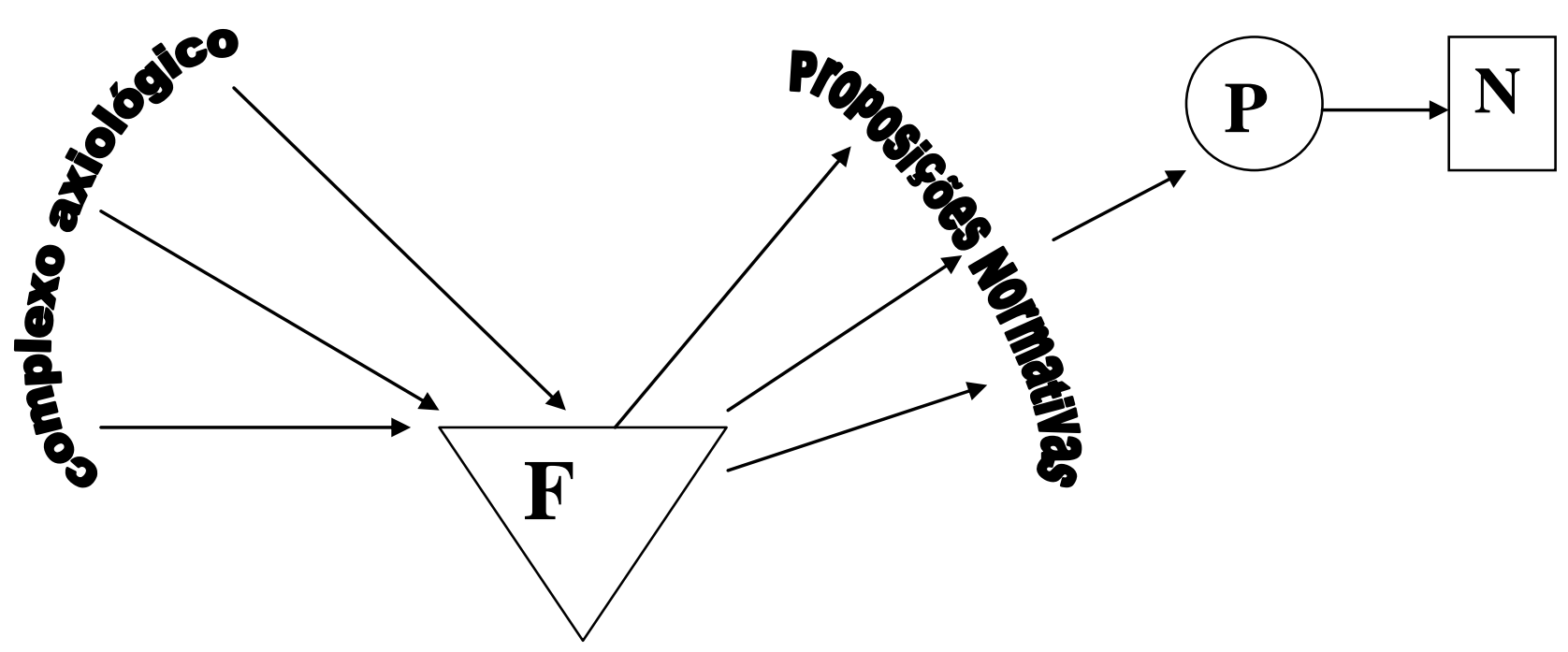

\section{Nomogênese Jurídica}

\footnotetext{
${ }^{9}$ REALE, Miguel. Teoria Tridimensional do Direito, situação atual, 5 ed. rev. e aum. - São Paulo: Saraiva, 1994, p 123/124.
} 
Com essa figura, quero dizer que o mundo jurídico é formado de contínuas "intenções de valor" que incidem sobre uma "base de fato", refragendo-se em várias proposições ou direções normativas, uma das quais se converte em norma jurídica em virtude da interferência do Poder.

A meu ver, pois, não surge a norma jurídica espontaneamente dos fatos e dos valores, como pretendem alguns sociólogos, porque ela não pode prescindir da apreciação da autoridade (lato sensu) que decide de sua conveniência e oportunidade, elegendo e consagrando (por intermédio da sanção ${ }^{10}$ ) uma das vias normativas possíveis. Todos os projetos de lei, em suma, em debate no Congresso, para dar um exemplo - perdem sua razão de ser quando um deles se converte em norma legal.

Essa compreensão da gênese da norma jurídica graças à participação do Poder num complexo factual--axiológico (onde, pois, não impera a vontade nua e arbitrária) é outra das contribuições dos meus estudos. Note-se que, quando falo em Poder, não penso apenas no Poder governamental, pois, mediante sucessivas decisões homogêneas, o Poder Judiciário edita normas jurisprudenciais (ex: as súmulas do STF) assim como o poder social anônimo consagra normas costumeiras ou consuetudinárias. Há ainda o Poder negocial que dá vida aos contratos. (gn)

Explica-nos Paulo Portela ${ }^{11}$ que, tradicionalmente, o objeto do Direito Internacional restringia-se a limitar as competências de Estados e de organizações internacionais, conferindo-lhes direitos e impondo-lhes obrigações, com vistas a reduzir a anarquia na sociedade internacional, ainda marcada pela inexistência de um poder mundial superior a todos os Estados e pelo fenômeno da coordenação de interesses, e não da subordinação.

\footnotetext{
${ }^{10}$ definição sanção s.f. : 1. aprovação de uma lei, pelo chefe do poder executivo, votada por órgão legislativo \# rejeição. 2.p.ext. aprovação ou confirmação que se dá, ou se impõe à lei. 3. p.ext. reconhecimento público; confirmação $\neq$ rejeição. 4. medida de repressão imposta por órgão ou autoridade. HOUAISS, Antônio e VILLAR, Mauro de Salles, Minidicionário Houaiss da língua portuguesa - 2 ed. rev. e aum - Rio de Janeiro : Objetiva, 2004. ISBN 85-7302-623-5 (DHou)

11 PORTELA, Paulo Henrique Gonçalves. Direito Internacional Público e Privados, incluindo noções de direitos humanos e de direito comunitário. 3 ed. , editora juspodium p. 48.
} 
Na atualidade, o objeto do Direito Internacional vem se ampliando, passando a incluir também a regulamentação da cooperação internacional, pautando o modo pelo qual os Estados, as organizações internacionais e outros atores deverão proceder para atingir objetivos comuns, normalmente ligados a problemas globais, como proteção do meio ambiente, ou a interesses regionais, a exemplo da integração regional.

Como os problemas tratados dentro das iniciativas de cooperação internacional, muitas vezes, referem-se a matérias também reguladas pelos ordenamentos internos dos Estados, pode-se afirmar que o Jus inter gentes ${ }^{12}$ inclui como objeto conferir tutela adicional a questões cuja importância transcende as fronteiras estatais, como os direitos humanos e o meio ambiente, disciplinando a forma pela qual todos os integrantes da sociedade internacional, inclusive os indivíduos, deverão conduzir seus comportamentos com vistas alcançar objetivos de interesse internacional.

O objeto do Direito Internacional é sintetizado por Amaral Júnior ${ }^{13}$, que afirma:

Desde as suas origens, o Direito Internacional Público cumpre duas funções básicas: reduzir a anarquia por meio de normas de conduta que permitam o estabelecimento de relações ordenadas entre os Estados Soberanos e satisfazer as necessidades e interesses dos membros da comunidade internacional.

Ainda nesse sentido, Seitenfus ${ }^{14}$ lembra que a Corte Internacional de Justiça proclamou que o Direito Internacional Público "constitui fator de organização da sociedade que atende a duas missões bem mais amplas: a redução da anarquia nas relações internacionais e a satisfação de interesses comuns entre os Estados". (gn)

O estudo do fundamento do Direito Internacional Público visa a determinar o motivo pelo qual as normas internacionais são obrigatórias. O fundamento do

\footnotetext{
${ }^{12}$ Teminologia: Direito Internacional Público (Bentham - 1780, com o intuito de diferenciar o Direito que cuida das relações entre os Estados, também designaodos em inglês como nations, do Direito doméstico National Law - e do Direito Municipal - Municipal Law.). Há autores que se referem ao Direito Internacional como o "Direito das Gentes", tradução literal do jus gentium do Direito Romano e que predominava até o século XVIII, ou Jus inter gentes, expressão cunhada no século XV por Francisco de Vitória, que significaria "Direito entre Estados".

13 AMARAL JÚNIOR, Alberto do. Manual do candidato: direito internacional, .79.

${ }^{14}$ SEITENFUS, Ricardo. Introdução ao direito internacional público, p.23.
} 
DIP é objeto de debates doutrinários, que se concentram principalmente ao redor de duas teorias: a voluntarista e a objetivista ${ }^{15}$.

O voluntarismo é uma corrente doutrinária de características subjetivistas, cujo aspecto central é a vontade dos sujeitos de Direito Internacional. Para o voluntarismo, os Estados e as organizações internacionais devem observar as normas internacionais, porque expressaram livremente sua concordância em fazê-lo, de forma expressa (por meio de tratados) ou tácita (pela aceitação generalizada de um costume). $\mathbf{O}$ Direito Internacional, portanto, tem como suporte o consentimento dos Estados. É também chamado de "corrente positivista". Essa doutrina é criticada por condicionar toda a regulamentação internacional, inclusive aquela concernente a matérias de grande importância para a humanidade, à mera vontade dos Estados, normalmente vinculada a inúmeros condicionamentos. (gn)

A doutrina voluntarista desenvolveu-se em várias vertentes, que são as seguintes: (i) autolimitação da vontade (Georg Jellinek): o Estado, por sua própria vontade, submete-se às normas internacionais e limita sua soberania; (ii) vontade coletiva (Heinrich Triepel): o Direito Internacional nasce não da vontade de um ente estatal, mas da conjunção das vontades unânimes de vários Estados, formando uma só vontade coletiva; (iii) consentimento das nações (Hall e Oppenheim): o fundamento do Direito das Gentes é a vontade da maioria dos Estados de um grupo, exercida de maneira livre e sem vícios, mas sem a exigência da unanimidade; (iv) delegação do Direito Interno (ou do "Direito estatal externo" de Max Wenzel), para a qual o fundamento do Direito Internacional é encontrado no próprio ordenamento nacional dos entes estatais.

O objetivismo sustenta que a obrigatoriedade do DIP decorre da existência de valores, princípios ou regras que se revestem de uma importância tal que delas pode depender, objetivamente, o bom desenvolvimento e a própria existência da sociedade internacional. Nesse sentido, essas normas, que surgem com base na própria dinâmica da sociedade internacional e que existem independentemente da vontade dos sujeitos de DIP, colocam-se acima da vontade dos Estados e devem, portanto, pautar as relações internacionais, devendo ser respeitadas por todos. A doutrina objetivista, por sua vez, ao minimizar o papel da vontade dos atores internacionais na criação das

15 PORTELA, Paulo Henrique Gonçalves. Direito Internacional Público e Privados, incluindo noções de direitos humanos e de direito comunitário. 3 ed., editora juspodium. p.49 e sgts. 
normas internacionais, coloca, também, em risco a própria convivência internacional, ao facilitar o surgimento de normas que podem não corresponder aos anseios legítimos dos povos. (grifos nossos)

O objetivismo também inclui vertentes teóricas, como as seguintes: (i) Jusnaturalismo (teoria do Direito Natural): as normas internacionais impõem-se naturalmente, por terem fundamento na própria natureza humana, tendo origem divina ou sendo baseadas na razão; (ii) teorias sociológicas do Direito: a norma internacional tem origem em fato social que se impõe aos indivíduos; (iii) teoria da norma-base de Kelsen: o fundamento do Direito Internacional é a norma hipotética fundamental, da qual decorrem todas as demais, inclusive as do Direito Interno, até porque não haveria diferença entre normas internacionais e internas; (iv) direitos fundamentais dos Estados: o Direito Internacional fundamenta-se no fato de os Estados possuírem direitos que lhe são inerentes e que são oponíveis em relação a terceiros.

As críticas a essas duas correntes levaram à formulação de uma teoria, elaborada por Dionísio Anzillotti que fundamenta o DIP na regra da pacta sunt servanda ${ }^{16}$. Para esse autor, o Direito Internacional é obrigatório para conter normas importantes para o desenvolvimento da sociedade internacional, mas que ainda dependem da vontade do Estado para existir. Ademais, a partir do momento em que os Estados expressem seu consentimento em cumprir certas normas internacionais (ratificação), devem fazê-lo de boa-fé.

Entendemos que o fundamento do Direito Internacional efetivamente inclui aspectos voluntaristas e objetivistas. Nesse sentido, concordamos com a definição conceitual explicada, textualmente, por Paulo Portela ${ }^{17}$ :

Os Estados obrigam-se a cumprir as normas internacionais com as quais consentiram, entretanto o exercício da vontade estatal não pode violar o jus cogens, conjunto de preceitos entendidos como imperativos e que, por sua importância, limitam a vontade estatal, nos termos da Convenção de Viena sobre o Direito dos

\footnotetext{
${ }^{16}$ pacta sunt servanda: Os pactos devem ser observados. (Cumpram-se os pactos). in ARAUJO, Ruy Magalhães de. Expressões Jurídicas Latinas Aplicadas ao Cotidiano Forense

17 PORTELA, Paulo Henrique Gonçalves. Direito Internacional Público e Privados, incluindo noções de direitos humanos e de direito comunitário. 3 ed., editora juspodium. p.51.e sgts.
} 
Tratados, de 1969 (artigo 53), que determina que é nulo um Tratado que, no momento de sua conclusão, conflite com uma norma de Direito Internacional aceita e reconhecida pela comunidade internacional dos Estados como um todo como preceito do qual nenhuma derrogação é permitida.

Os críticos teóricos alegam que as normas internacionais têm natureza meramente moral e de pura cortesia, e que seria impossível haver uma ordem jurídica internacional enquanto não existir uma sociedade mundial organizada. Os críticos práticos ora afirmam que os Estados atuam unicamente em função de seus interesses, ora que as relações internacionais são baseadas apenas na força, ou, ainda, que a ordem jurídica internacional carece de coercitividade. Por fim, há quem afirme que o Direito das Gentes não tem relevância e utilidade, visto que, na convivência internacional, acabariam prevalecendo apenas os interesses dos Estados, que se impõem segundo os respectivos diferenciais de poder, ficando eventual aplicação das normas internacionais vinculada a considerações de aspecto político, econômico, militar etc.

Não avançaremos no exame dessas ideias, porque não temos dúvida acerca das características jurídicas do DIP. Com efeito, não é difícil verificar que existe um ordenamento jurídico internacional, formado por um conjunto de preceitos voltados a regular as condutas dos membros da sociedade internacional e o tratamento de temas de interesse global. Assim como os demais preceitos jurídicos, as normas internacionais são obrigatórias e, com frequência, contemplam, expressamente, a possibilidade de sanções no caso de seu descumprimento, entretanto, é certo que o DIP apresenta algumas peculiaridades em relação ao Direito Doméstico.

O Jus inter gentes é, fortemente marcado pela dicotomia entre a relativização da soberania nacional e a manutenção de sua importância. Com efeito, O DIP efetivamente implica nova concepção de poder soberano, não mais entendido como absoluto, mas sim sujeito a limites demarcados juridicamente, ideia, aliás, consentânea com o espírito do Estado de Direito. Desse modo, no momento em que um ente estatal celebra um tratado, ele submete-se à competência de um tribunal internacional ou mesmo à competência de um órgão de tratado ou multilateral, como é o caso da Comissão de Direitos Humanos/Conselho de Direitos Humanos das Nações Unidas, o que efetivamente restringe sua capacidade de deliberar sobre todos os assuntos de seu interesse. 
O poder soberano, por sua vez, ainda impõe limites ao Direito das Gentes. De fato, os Estados mantêm uma série de competências exclusivas no território sob sua jurisdição. Os entes estatais ainda são competentes para decidir a respeito da celebração de tratados e do modelo de incorporação das normas internacionais ao ordenamento interno, bem como de sua submissão a órgãos internacionais de soluções de controvérsias e de fiscalização do cumprimento de tratados. Por fim, o funcionamento da maioria das organizações internacionais continua a depender das deliberações e da colaboração dos Estados. (gn )

O DIP é um direito de "coordenação", em oposição ao Direito Doméstico, que é de "subordinação". Dentro dos Estados, as normas são elaboradas por órgãos estatais, representantes de um poder soberano capaz de se fazer impor aos particulares. Na ordem internacional, como não há poder central responsável por essa tarefa, a construção do ordenamento jurídico é fruto de um esforço de articulação entre Estados e organizações internacionais, que elaboram as normas internacionais com base em negociações e podem expressar seu consentimento em observá-las. Nesse sentido, o Direito das Gentes, quando entendido como Direito Interestatal, caracteriza-se, também, por suas normas serem criadas por seus próprios destinatários. (gn)

\section{O DIP distingue-se pela ampla descentralização da produção} normativa. Com efeito, enquanto o Direito de cada Estado tem o processo legislativo centralizado em poucos órgãos definidos pelo ente estatal, com regras determinadas pelo ordenamento jurídico nacional, a produção das normas internacionais ocorre em vários âmbitos, a exemplo das diversas organizações internacionais ou das articulações entre dois Estados específicos, podendo cada negociação desenvolver-se conforme regras diferentes uma das outras.

O Jus inter gentes não é um mero conjunto de intenções de características políticas, de regras de cortesia ou de simples acordos de cavaleiros. De fato, o ordenamento internacional é composto por um conjunto de normas jurídicas, obrigatórias para seus destinatários, formando aquilo que Bruno Yepes Pereira chama de "ordem normativa" $^{18}$.

${ }^{18}$ PEREIRA, Bruno Yepes, Curso de direito internacional público, p.45 
Parte da doutrina afirma que não existe hierarquia entre as normas do DIP, por conseguinte, um tratado entre dois entes estatais não necessariamente teria de conformar às normas de outros tratados firmados entre esses mesmos Estados, e somente o exame de cada caso concreto permitiria identificar um preceito internacional ao qual se deveria atribuir maior importância. Essa característica, por sua vez, não cobre todas as situações que ocorram na sociedade internacional. Com efeito, um tratado não pode estar em conflito com as normas do jus cogens. Em regra, acordos firmados entre Estados de uma região do mundo, como a América do Sul, relativos a determinadas matérias, como comércio, trabalho e direitos humanos, devem respeitar as normas de Direito Internacional Global, que podem ter como destinatário qualquer Estado. Por fim, deve-se atentar aos princípios que orientam o ordenamento jurídico internacional, privilegiando-se aquelas normas que concretizam os principais valores protegidos pela sociedade internacional. (gn)

Por fim, o Direito Internacional Público destina-se não só a gerar efeitos no âmbito das relações internacionais, mas também dentro dos Estados. Com efeito, as normas internacionais prescrevem condutas que deverão ser executadas exatamente pelas autoridades responsáveis pela condução das relações internacionais de um ente estatal. Além disso, os tratados normalmente determinam ações que os Estados deverão efetivar dentro de seus territórios, como no caso do Protocolo de Quioto, ato internacional que visa a reduzir poluição ambiental no mundo e que, para isso, deverá logicamente levar à redução da emissão de poluente pelas indústrias nacionais, ou dos tratados de direitos humanos, que não lograrão contribuir para a proteção e a promoção da dignidade humana no mundo, se os Estados, sob cuja jurisdição se encontrarem as pessoas naturais, não garantirem o gozo dos direitos consagrados em seus textos nas respectivas áreas territoriais.(gn) 


\section{3 - REFLEXÃO HISTÓRICO-AXIOLÓGICA NO FIM DA PAX BRITANNICA E DURANTE OS 20 ANOS DE CRISE}

(1919-1939)

Segundo Miguel Reale,

a " tarefa que se nos antolha ${ }^{19}$ não é por certo a de volver à estática concepção substancialista da pessoa, mas antes a de superar, em nova compreensão, o valor da pessoa e o valor da história, conciliando a radical liberdade constitutiva de valores, que é o homem enquanto pessoa (tal como Kant nos revelou), com o drama histórico das pessoas coexistentes (que Hegel quis abranger em poderosa unidade integrante). Pessoa e convivência histórico-social são termos que se exigem reciprocamente, visto como - e este ponto é essencial - pôr-se como pessoa é pôr-se como história, como alteridade, como comunidade, e a redução de uma à outra romperia a unidade concreta, o mesmo resultando se prevalecesse uma sobre a outra.(grifos nossos)

${ }^{19}$ Dicionário Houaiss (DHou) : antolhos - par de peças colocadas ao lado dos olhos de animal de montaria, para que ele só olhe para frente. 


\subsection{1 - ANOTAÇÃO METODOLÓGICA}

Antes de prosseguirmos, é necessário explicarmos à leitora e ao leitor o uso da metodologia científica a seguir. Primeiramente, precisamos dizer que o conhecimento científico é uma produção humana e, como tal, está sujeita a todas emoções, erros, acertos, dúvidas e certezas que qualquer ser humano pode ter. Segundo Peduzzi e Kohnlein ${ }^{20}$ :

Em seu trabalho, o cientista está sujeito tanto às virtudes quanto aos defeitos que caracterizam o envolvimento do ser humano em qualquer atividade que realiza.

A ciência não é constituída de teorias e leis que são conhecimentos finais. As teorias evoluem. O que é verdade científica hoje, aceita inclusive pelo meio científico, pode não passar de uma teoria ultrapassada amanhã. O conhecimento científico, segundo filósofos da ciência contemporâneos, não é definitivo e, muito menos, verdade absoluta ${ }^{21}$. Acreditamos que os cientistas compreendam, de forma adequada, que a constituição do conhecimento científico possa contribuir para o refinamento do pensamento crítico. ${ }^{22}$

No campo da ciência que estuda a mente, por exemplo, certos psicólogos soviéticos costumavam citar em excesso os clássicos do marxismo, procurando, dessa forma, um meio de construir uma psicologia marxista em meio ao caos das escolas

${ }^{20}$ PEDUZZI, L.O.Q.; KOHNLEIN, J.F.K. Sobre a Concepção Empirista-Indutivista no Ensino de Ciências. in VIII Encontro Nacional de Pesquisa em Ensino de Física, São Paulo, 5-8 Junho de 2002, p.18. Empirismo: defende que a fonte de conhecimento é a experiência sensível.

Indutivismo: defende que há justificativa lógica para a obtenção de enunciados universais com base em enunciados singulares.

${ }^{21}$ KUHN, T.S. A Estrutura das Revoluções Científicas. São Paulo, Perspectiva, 2003, p.260; POPPER, K.L. A Lógica da Pesquisa Científica. São Paulo, Cultrix, 2003.p.556.

${ }^{22}$ Depois de testemunhar a primeira detonação atômica da humanidade, um dos 'pais da bomba atômica teve o seguinte insight:

"-Sabíamos que o mundo não seria o mesmo.

Algumas pessoas riram, algumas pessoas choraram, a maioria das pessoas ficou em silêncio.

-Lembrei-me da frase do texto sagrado hindu, o Bhagavad-Gita.

Vishnu está tentando persuadir o príncipe que ele deveria fazer o seu dever, e para impressioná-lo, assume sua forma multiarmada, e diz:

<Agora eu me tornei a Morte, o destruidor de mundos>".

'Acho que todos nós pensamos isso, de uma maneira ou de outra". in http://pensador.uol.com.br/autor/robert_oppenheimer/ 
antagônicas existentes. Ainda que, em notas não publicadas, L.S. Vigotski ${ }^{23}$ tenha repudiado o "método das citações" como meio de relacionar marxismo e psicologia, tornando explícita a maneira pela qual ele julgava que seus princípios metodológicos básicos pudessem contribuir para a elaboração de uma teoria na psicologia. A leitura cuidadosa de seu manuscrito nos fornece provas convincentes da sinceridade de L.S.Vigostky em contribuir para o desenvolvimento teórico das ciências psicológicas.

Não quero descobrir a natureza da mente fazendo uma colcha de retalhos de inúmeras citações. O que eu quero é, uma vez tendo apreendido a totalidade do método de Marx, saber de que modo a ciência tem de ser elaborada para abordar o estudo da mente.

...Para criar essa teoria-método de uma maneira científica de aceitação geral, é necessário descobrir a essência dessa determinada área de fenômenos, as leis que regulam as suas mudanças, suas características qualitativas e quantitativas, além de suas causas. É necessário, ainda, formular as categorias e os conceitos que lhes são especificamente relevantes - ou seja, em outras palavras, criar o seu próprio Capital.

O Capital está descrito de acordo com o seguinte método: Marx analisa uma única "célula" viva da sociedade capitalista - por exemplo, a natureza do valor. Dentro dessa célula ele descobre a estrutura de todo o sistema e de todas as suas inquietações econômicas. Ele diz que, para um leigo, essa análise poderia parecer não mais do que um obscuro emaranhado de detalhes sutis. De fato, pode até ser que haja esses detalhes sutis; no entanto, eles são absolutamente necessários à "microanatomia". Alguém que pudesse descobrir qual é a célula "psicológica" - o mecanismo produtor de uma única resposta que seja - teria, portanto, encontrado a chave para a psicologia como um todo. (de cadernos não publicados).

23 VIGOTSKY, Lev Semenovich.1896-1934. A formação social da mente : do desenvolvimento dos processos psicológicos superiores. $7^{\mathrm{a}} \mathrm{ed}$ - São Paulo: Martins Fontes, 2007. (Psicologia e Pedagogia) 
O uso da imagem gráfica é empregado desde que o homem surgiu na Terra e começou a usá-la para inscrição nas paredes das cavernas, como meios de comunicação para informações essenciais, como a demarcação de um território e a conquista de uma presa entre outras. Com a crescente evolução que a imprensa gráfica fez uso nas Revoluções Industrial, Norte-Americana e Francesa, criou-se um cenário propício para seu estabelecimento como meio de comunicação em massa. Com fortes aspectos linguísticos que uma história em quadrinhos (HQ) contém, foi nos Estados Unidos que atingiu seu apogeu no final do século XIX, em razão da disponibilidade tecnológica que o país desfrutava e de sua cultura social consumista, as quais favoreceram a consolidação das HQs como um produto de consumo de $\operatorname{massas}^{24}$. Mesmo na contemporaneidade, o ser humano registra suas impressões do mundo desde pequeno, na forma de desenhos, com um único motivo simples: comunicar-se.

A prática pedagógica baseada na transmissão e acumulação de conteúdos desconsidera o fazer do leitor, bem como pune as habilidades de cada indivíduo. Acumular conhecimento sem um propósito concreto de transformação social é o propósito da construção de máquinas que arquivam informações para que sejam acessadas a qualquer momento ${ }^{25}$. Refletir sobre a popularização da ciência e do método científico, aproximar o lúdico do científico e o popular, disseminar a ciência com qualidade sem perder a credibilidade e de forma informal são grandes desafios para os profissionais da educação em atrair a atenção dos alunos para dentro da sala de aula, promovendo-lhes um ensino mais contextualizado e divertido.

De fato, muito mais que trazer consigo a diversão e o lazer, as HQs são extremamente capazes de rechear suas histórias com conteúdos, nos quais seu principal aliado são os personagens, em razão da sua fala familiar, a capacidade de aproximar-se do leitor e dos diversos conceitos nelas embutidos, tornam-se um material muito atrativo, para alunos e professores ${ }^{26}$.

\footnotetext{
${ }^{24}$ RAMA,A; VERGUEIRO, W. Como usar as histórias em quadrinhos na sala de aula. São Paulo, Contexto, 2004.

${ }^{25}$ SHANIK,R.C. O que saber e como aprendê-lo. in As coisas são assim, BROCKMAN, J; MATSON, K. (Orgs), São Paulo, Cia das Letras, 2008

${ }^{26}$ PIZARRO, M.V. Histórias em quadrinhos e o ensino de Ciências nas séries iniciais: estabelecendo relações para ensino de conteúdos curriculares procedimentais, 2009, Dissertação (Mestre em Educação para a Ciência)- UNESP, Faculdade de Ciências, Bauru, 2009, p.188.
} 
O ensino da ciência não deve ser mais um ensino de pura transmissão de conceitos e de conteúdos científicos, mas de um processo de "aculturação científica"27. Uma das ferramentas que pode ser usada nesse processo de aculturamento é a história em quadrinhos, em razão de sua popularidade, da fácil linguagem empregada, da ampla disseminação mundial, do uso de desenhos, de expressões faciais; enfim, vários são os atrativos disponíveis em uma história em quadrinhos ${ }^{28}$.Como forte aliado pedagógico, as HQs propiciam à leitora e ao leitor o contato com narrativas desde o começo do aprendizado até a aquisição de nova linguagens. As imagens apoiam o texto e dão à leitora e ao leitor pistas conceituais para o significado da palavra. Os quadrinhos atuam como uma espécie de andaime para o conhecimento do estudante ${ }^{29}$.

A incrível vantagem de fazer uso das HQs no ensino das ciências é a sua forma própria, ao aliar imagem e escrita, na qual aquela consegue expressar uma ideia muito mais fácil e dinâmica que a escrita no que diz respeito a provocar o interesse da leitora e do leitor, a demonstrar um pensamento e a descrever um acontecimento.

De acordo com Linsingen ${ }^{30}$, as HQs podem ser usadas como ferramenta tecnológica de ensino, pois segundo a ótica Ciência,Tecnologia,Sociedade(CTS) :

as HQs surgiram como uma forma de ver o conhecimento como um todo socialmente construído e como uma inspiração para uma postura escolar menos impositiva e dogmática, que priorize a reflexão crítica e a construção do conhecimento em um cidadão apto a intervir de forma consciente na sociedade.

Refletir sobre a popularização da ciência e do método científico, aproximar o lúdico do científico e o popular, disseminar a ciência com qualidade sem perder a credibilidade e de forma informal são grandes desafios para os profissionais da educação para atrair a atenção dos alunos em sala. Vencer esse quadro é o primeiro grande

${ }^{27}$ CARVALHO de, A.M.P. Critérios Estruturantes para o ensino de ciências. São Paulo, Pioneira Thomsom Learning, 2004.

${ }^{28}$ ARAÚJO de, J.C.; COSTA de, M.A. A Margem - Estudos Uberlândia, MG, p.26-36, 2008

${ }^{29}$ LUYTEN, S.M.B. História em Quadrinhos. Um recurso de aprendizagem. Introdução; in História em Quadrinhos.Um recurso de aprendizagem. MELLO de Souza, M.C. (Orgs) Brasília:MEC, 2011.

${ }^{30}$ LINSINGEN, L. Mangás e sua utilização pedagógica no ensino das ciências sob a perspectiva Ciência Tecnologia e Sociedade (CTS). Ciência \& Ensino, Campinas,v.1., número especial,p.1/9, novembro,2007.p.4. 
desafio. Segundo Caruso ${ }^{31}$,

nossa contribuição, nesse sentido, parte de uma particular concepção de educador, a qual dificilmente poderia ser mais bem expressa do que as palavras de Jean Jacques Rousseau:

"Ousarei expor... a mais importante, a maior, a regra mais útil de toda a educação: é não ganhar, mas perder tempo! Já é hora de os cientistas saírem de seus laboratórios e bibliotecas e perderem tempo com a divulgação da ciência, de discutirem o ensino de ciências - E por que não ? - de contribuírem, efetivamente, para a alfabetização científica.

${ }^{31}$ CARUSO, F.; SILVEIRA,C. Quadrinhos para a cidadania. História, Ciências, Saúde - Manguinhos, Rio de Janeiro, v.16,n1,jan-mar,2009. 


\section{4- A DIALÉTICA DA COMPLEMENTARIEDADE E O MUNDO DA CULTURA DIPLOMÁTICA ${ }^{32}$}

Ensina-nos, textualmente, Miguel Reale sobre a estrutura do Direito, bem como a formação de modelos jurídicos:

Por intermédio das múltiplas formas de correlação entre fatos, valores e normas, surgem e se desenvolvem distintos círculos de experiência jurídica, os quais, por sua vez, se influenciam e se interpenetram, constituindo em cada país, uma experiência jurídica global, a qual não é a criação do Estado, mas tem no Estado o seu ponto de referência, em termos de validade e de eficácia. (gn)

[...] Desde O Direito como Experiência (1968), tenho me preocupado com a imanente consistência estrutural do Direito, mostrando que a Ciência Jurídica não teria sido possível (como demonstram os jurisconsultos romanos) se a vida social não apresentasse determinadas relações dotadas tanto de estabilidade quanto de previsibilidade. Se os homens, em suas relações de convivência, não obedecessem a certas linhas de referência, como diretriz provável de conduta; se não houvesse, em suma, determinadas "constantes de ação", pelo menos dentro de certa conjuntura histórica, teria sido impossível cogitar-se de regras jurídicas destinadas a reger ou expressar "a ordem dos atos humanos". A categorização normativa, que se estadeia no Direito Romano, nasceu do senso que a gente do Lácio teve dos valores pragmáticos da existência, e da percepção de que, não obstante as variações dos comportamentos, algo há que perdura, que possui uma "duração" suscetível de medida e de previsibilidade.

${ }^{32}$ Recomendamos à leitora e ao leitor lerem o anexo antes de seguirem leitura deste capítulo. 
Como forma de confirmar essa obediência a certas linhas de referência como diretriz provável de conduta, cabe destacar a evolução do pensamento de Sigmund Freud em um contexto de fim da Pax Britannica. Com sua conquista revolucionária relativa à psicologia do inconsciente, Freud feriu o orgulho do Ocidente. Ademais, esta explicitação funcionará como uma exceção que confirma a regra acima mencionada, uma vez que tanto Freud quanto a consciência da humanidade se enganaram com respeito à ação $^{33}$ e às intenções nazistas. Morreu, exilado no Reino Unido, em 23 de setembro de 1939, antes, portanto, do início da Segunda Guerra Mundial e da promulgação do decreto noite e neblina, cujo objetivo foi de aplicar a "solução final" aos povos minoritários, em sua maioria judeus.

Com o benefício de algum tempo e distância do ocorrido, explica-nos Miguel Reale :

Nada de extraordinário há nessa constatação se partirmos da afirmação da atual Antropologia, desde Lévi-Strauss, de que o pensamento humano, mesmo o "pensamento selvagem" ou inculto, já tem a sua lógica própria, ao contrário da compreensão oitocentista de uma "era mítica" progressivamente transformada ou evoluída em uma "era lógica".

No fundo, há dois valores que merecem ser lembrados concomitantemente, não obstante suas renovadas antinomias: a logicidade e a historicidade do ser humano. É em virtude desses dois valores constitutivos do homem, que este não só pensa, mas torna objetivo, extrapola de si aquilo que pensa, convertendo em "objetividades" as "intencionalidades"

\footnotetext{
${ }^{33}$ William Hodgson da Austrália perguntou-se retoricamente o que significava a frase "Direitos Humanos" e, então, respondeu :

"Nós nos referimos, ou pensamos em MINORIAS".

A maioria dos artigos da Declaração foi redigida como uma resposta direta aos horríveis excessos das políticas racistas de Hitler. A primeira atitude que as Potências Aliadas tomaram, após a Segunda Guerra, foi desmantelar as estruturas jurídicas racistas do Fuhrer.

O quarto princípio político anunciado na Conferência da Potsdam em 1945 afirmava que :

"todas as leis nazistas que fundamentaram o regime hitlerista ou estabeleceram discriminações com base na raça, na crença, nas opiniões políticas deverão ser abolidas".

in MORSINK, Johannes, The Universal Declaration of Human Rights : Origins , Drafting and Intent, University of Pennsylvania Press, 1999.p.102
} 
que são próprias de sua consciência (e, aderimos à Freud) de sua inconsciência

Logicizando e "objetivizando" aquilo que é percebido e pensado, ainda que rudimentarmente numa sequência interminável de tentativas, de erros e correções, de avanços e recuos, o homem vai constituindo, sobre o "mundo da natureza", o "mundo da cultura", o qual poderia ser considerado "o mundo das intencionalidades objetivizadas e objetivadas no decurso do tempo".(gn)

O Direito, como parte essencial dessa experiência histórica do homem, não podia deixar de ser uma experiência de "estruturas práticas" e, por fim, de estruturas paradigmáticas ou de modelos. Por mais elementares que sejam, as estruturas sociais representam uma ordenação de elementos interdependentes, ligados entre si, em razão de certos fins que se quer atingir. Toda estrutura social é, em última análise, uma ordenação axiológica de fatos ou de atos, na medida de um fim visado. (gn)

Quando uma estrutura não se destina apenas a representar, em unidade orgânica, determinados aspectos da realidade social, mas implica, também, o problema de seu "sentido", e, por conseguinte, dos comportamentos que este postula, dizemos que ela adquire o valor de um modelo. (gn)

Ora, ao analisarmos a experiência social, como se dá no caso do Direito ou da Política, verificamos a reiteração constante de certos atos ou comportamentos organicamente correlacionados, visando a alcançar objetivos mais ou menos permanentes, ou pelo menos estáveis, envolvendo uma pluralidade convergente de interesses individuais ou grupalistas. Dizemos, então, que surge uma estrutura social. 


\section{As estruturas sociais não têm a mesma gênese,} resultando de múltiplos fatores. Umas são, por assim dizer, "naturais", no sentido de que refletem necessidades biopsíquicas inerentes à convivência humana ${ }^{34}$; outras são a consequência da convergência de atos e fatos originariamente isolados, mas que, aos poucos, se compõem em unidade orgânica ${ }^{35}$; outras, ainda, já surgem, desde logo, dotadas de unidade planificada, e, como tal, racionalmente querida ${ }^{36}$.

Em âmbito internacional essa dialética de complementariedade ${ }^{37}$ nomotética pode ser compreendida mediante o estudo histórico relacionado às pressões políticas para a elaboração de uma carta internacional de direitos humanos na própria Carta da ONU, ao processo de diplomacia parlamentar que discutiu os direitos dos seres humanos em âmbito universal e que, por fim, resultaria na promulgação da DUDH1948 ${ }^{38}$.

Antes de adentrarmos no tocante à colocação do problema da sociedade e da história em termos de experiência, lembra-nos Miguel Reale que não se pode, outrossim, esquecer que a meditação das obras de Hume não teve o condão de despertar Kant para uma compreensão mais concreta do Direito e do Estado, máxime se recordarmos que o Tratado da Natureza Humana, como demonstrou Luigi Bagolini, pode ser considerado o primeiro ensaio de introdução do método experimental no campo das disciplinas morais ${ }^{39}$.

\footnotetext{
${ }^{34}$ Expansionismo do Terceiro Reich com base no seu espaço vital pode ser um exemplo.

${ }^{35}$ A nomogênese da Declaração Universal dos Direitos Humanos pode ser um exemplo.

${ }^{36}$ o fenômeno desnutrição-obesidade pode ser visto como efeito desse tipo de estrutura racionalmente planificada muito recentemente, remontando aos estudos pioneiros de Josué de Castro em suas obras Geopolítica da Fome e Geografia da Fome, o Dilema entre o Pão e o Aço.

${ }^{37} \mathrm{o}$ conceito será mais apropriadamente apresentada adiante. v.p.39

${ }^{38}$ Adiante, quando tratarmos do modelo doutrinário e prescritivo do Comitê de Direitos Econômicos, Sociais e Culturais, aplicaremos a mesma diáletica da complementariedade.

39 cf. BAgOLINI, LUIGI, Esperienza Giuridica e Politica nel Pensiero di David Hume, $2^{\mathrm{a}}$ ed, Turim, 1967,p.157.
} 
Como alerta Miguel Reale ${ }^{40}$ :

Poderia parecer a um estudioso superficial ou apressado que, na ampla tela de ideias, cujo esboço procurei fixar nas páginas anteriores, os elementos apenas se justapõem, desprovidos de um travamento interno assegurador de sua unidade coerente.

Não que me preocupe com a acusação de ecletismo, que é a mais fácil e, por isso mesmo, a mais frequente das críticas movidas a qualquer filósofo, bastando, para tal proeza, desarticular, abstratamente, os elementos integrantes de um pensamento, deformando-o no ato mesmo em que a desarticulação é feita. Mais gravemente é, porém, quando não se leva em conta a linha evolutiva de uma doutrina, fazendo-se justaposições ou confrontos anacrônicos entre asserções relativas a épocas diversas.

Meu propósito é tão somente mostrar como o tridimensionalismo jurídico veio se desenvolvendo, obediente intrínsecas necessidades, e como a tridimensionalidade específica corresponde, no caso particular da experiência do direito, a uma compreensão mais viva do homem e do mundo histórico por ele constituído.(gn)

Ora, a Filosofia da cultura constitui-se, de um lado, como reação ao empobrecimento a que o positivismo submetera a imagem do real, contentando-se com as suas conexões aparentes ou fenomenais, sem sequer cuidar do valor ou do significado dessas "aparências"; e, de outro, marcou uma tentativa de superamento do dualismo kantiano, consoante o já apontado, especialmente no sentido de contornar o impasse que as três

${ }^{40}$ REALE, Miguel. Teoria Tridimensional do Direito, situação atual, 5 ed. rev. e aum. - São Paulo: Saraiva, 1994, p.67 e sgts 
Críticas haviam deixado para o problema da história ${ }^{41}$.

Reportando-me ao já exposto em minha Filosofia do Direito, não será demais recordar que com Kant se dá uma fratura no mundo fenomenal, em razão da separação cortante por ele feita entre o "mundo da liberdade" e o "mundo da natureza", ou, por outras palavras, entre o "campo da ética" e o "campo da ciência", de tal modo que somente com relação a este seria possível falar-se em experiência, propriamente dita ${ }^{42}$

Transpondo a ética e, por conseguinte, o direito para o plano dos imperativos da vontade pura, Kant trancou a possibilidade de ver a história como uma outra forma teorética de experiência, e, como tal, também dotada de suas condições transcendentais de possibilidade, no plano da razão pura, marcando, a essa luz, um retrocesso em confronto com a posição já atingida por Vico, a quem se não pode recusar o mérito de haver lançado as bases categoriais das "ciências do espírito ${ }^{43 "}$

Foi mérito da Escola de Baden, a que se filiam Lask e Radbruch, ter percebido que, não obstante o corte feito por Kant entre ser e dever ser (mundo da liberdade e mundo da natureza), havia no kantismo um elemento-chave para a compreensão do mundo histórico : o conceito de valor.(gn)

\footnotetext{
${ }^{41}$ Note-se que, consoante os mais recentes estudos voltam a salientar, não escapou a KANT o problema do sentido da história. Para uma bibliografia fundamental, v. DINO PASINI "La concezione della storia in Kant", introdução à sua edição de KANT, Saggi sulla Storia, Milão 1955.

${ }^{42}$ É sobretudo na Crítica do Juízo e, mais precisamente, na $1^{\mathrm{a}}$ Introdução, que KANT redigiu para esta sua obra, que se notam as perplexidades surgidas desse divórcio entre a natureza e espírito, comprometendo a unidade mesma do espírito. Aliás, KANT mesmo sentiu a necessidade de superar o dualismo razão teorética-razão prática, como lembra JOHANNES HIRSCHBERGER, História da Filosofia Moderna, trad. de A. Correia, SP, 1960, p.338.

43 Sobre a contribuição de VICO à fundação das "ciências culturais" e o seu significado na atual compreensão da experiência jurídica ver o seguinte ensaio: REALE, Miguel. Giambattista Vico, a Jurisprudência e a descoberta do mundo do espírito", in Horizontes do Direito e da História, $2^{\text {a }}$ ed.,SP.
} 
Apesar de sua deficiência, representou um grande passo a ideia dos neokantianos de interpor, entre realidade e valor, um elemento de conexão: a cultura, significando o complexo das realidades valiosas, ou, como esclarece Radbruch, "referidas a valores". Isto equivale a dizer que todo bem de cultura (e o direito é um deles) é tridimensional em razão de seu simples enunciado, uma vez que pressupõe sempre um suporte natural ou real, e, no meu modo de ver, também ideal, suporte esse que adquire significado e forma próprios em virtude do valor a que se refere. Foi em torno dessa problemática que se desenvolveram as diversas espécies de culturalismo jurídico.

Desde o primeiro contato com a Filosofia dos valores, convenci-me da improcedência da doutrina da cultura como elemento intercalar, inserido entre a natureza e o valor, parecendo-me o resultado de um processo cognoscitivo abstrato, que não correlaciona devidamente sujeito e objeto como termos que se exigem reciprocamente numa relação de complementaridade, além de não superar outro abismo, o posto entre o ser e dever ser na vertente ética da ação.

Como tenho exposto em diversas oportunidades, se partirmos do conceito husserliano de "intencionalidade da consciência", ou seja, de que conhecer é sempre conhecer algo, passa a ser focalizada sob nova luz a tão reiterada afirmação da heterogeneidade entre sujeito e objeto, a qual, no fundo, pressupõe um dualismo radical entre a natureza e espírito, quando, efetivamente, o que há no plano do conhecimento, é uma correlação transcendental subjetivo-objetiva, ou ontognoseológica, que não permite se reduza o sujeito ao objeto, ou vice-versa, visto como algo haverá sempre a ser convertido em objeto e, ao mesmo tempo, algo haverá sempre a atualizar-se no tocante à subjetividade, mediante sínteses empíricas que se ordenam progressivamente no processo cognoscitivo. 
Dessa colocação do problema resulta o caráter dialético do conhecimento, que é sempre de natureza relacional, aberto sempre a novas possibilidades de síntese, sem que esta jamais se conclua, em virtude da essencial irredutibilidade dos dois termos relacionados ou relacionáveis. É a esse tipo de dialética, que denomino "dialética da complementariedade", da qual a dialética dos opostos, de tipo marxista ou hegeliano, não é senão uma expressão particular, com as modificações resultantes da análise fenomenológica de seus termos, notadamente para se desfazer a confusão entre 'contrários' e 'contraditórios'. No âmbito da dialética de complementariedade, dá-se a implicação dos opostos na medida em que se desoculta e se revela a aparência da contradição, sem que, com este desocultamento, os termos cessem de ser contrários, cada qual idêntico a si mesmo e ambos em mútua e necessária correlação. (gn)

É sobretudo no mundo dos valores e da praxis que mais se evidencia a existência de certos aspectos da realidade humana que não podem ser determinados sem serem referidos a outros aspectos distintos, funcionais, ou até mesmo opostos, mas ainda assim essencialmente complementares. Tal correlação de implicação não pode jamais se resolver mediante a redução de uns aspectos nos outros: na unidade concreta da relação instituída tais aspectos mantêm-se distintos e irredutíveis, daí resultando a sua dialeticidade, por intermédio de "sínteses relacionais" progressivas que traduzem a crescente e sempre renovada interdependência dos elementos que nela se integram. (gn)

É da estrutura mesma dos valores, como entidades polares, que resulta a dialeticidade de todos os "bens culturais" que a espécie humana constitui na faina histórica de dar valor às coisas e aos atos, constituindo, graças ao mundo da natureza dada, o mundo histórico-cultural.

Se no ato mesmo em que algo é conhecido já se 
põe o valor daquilo que se conhece e do cognoscível, vê-se que o valor é elemento de mediação também no plano gnoseológico, possibilitando a relação entre sujeito e objeto, na medida em que este se torna objeto em função de intencionalidade da consciência e nesta surge como objeto valioso.

O conhecimento é, dessarte, uma síntese ontognoseológica, acompanhada da consciência da validade da correlação alcançada, sendo certo que os valores, que se revelam no ato de conhecer, são resultantes de um valor primordial e fundante, sem cujo pressuposto a priori - e, neste ponto, a lição de Kant afigura-se-me imprescindível - não seria logicamente pensável sequer o processo gnoseológico: é o valor essencial do espírito como "síntese a priori", ou, por outras palavras, a compreensão da consciência como possibilidade originária de síntese. A correlação sujeito-objeto põe-se, desse modo, como "síntese transcendental" e condição possibilitante das sínteses empíricopositivas que constituem a trama da experiência humana.

A meu ver, a correlação entre sujeito e objeto é de complementaridade, a qual governa todo o processo espiritual, tanto no plano teorético quanto no da praxis, podendo, em resumo, dizer-se que, na dialética do tipo aqui exposto, há uma correlação permanente e progressiva entre dois ou mais termos, os quais não se podem compreender separados uns dos outros, sendo ao mesmo tempo irredutiveis uns aos outros; tais elementos distintos ou opostos da relação, por outro lado, só têm plenitude de significado na unidade concreta da relação que constituem, enquanto se correlacionam e dessa unidade participam $^{44}$. (gn)

44 Compare-se esse conceito de complementaridade com o que GASTON BACHELARD enuncia como 'princípio de complementariedade' aplicável nos domínios da Física atual, como tem sido feito por NIELS BOHR ou BROGLIE : 
A cultura, nesse contexto de ideias, não é algo intercalado entre o espírito e a natureza, mas antes um processo das sínteses progressivas que o primeiro vai realizando com base na compreensão operacional da segunda, o processo históricocultural coincidindo como o processo ontognoseológico e suas naturais projeções plano da praxis.(gn)

"o processo operatório pelo qual se trata de desvelar a aparência de uma exclusão recíproca de termos críticos, os quais se revelam à análise dialética como irmãos gêmeos, como pares que se afirmam uns em função dos outros, ou pelo menos entrando no mesmo conjunto" (cf. BACHELARD, Gaston. Le Rationalisme Appliqué, Paris, 1949, e L’Activité Rationelle de la Physique Contemporaine, Paris, 1951).

"Nesta concepção, como se vê, o princípio de complementariedade exerce apenas a função operacional de "desocultamento de contradições aparentes".

Note-se que se desfaz a "contradição, não a contrariedade", conforme tenho salientado em diversas obras"

(cf. STRENGER, Irineu, Fenomenologia e Criticismo Ontognoseológico, in Revista da Faculdade de Direito da Universidade de São Paulo, 1966, LXI, fasc. I, p.198 e sgts, e CZERNA, Renato Cirell, Ensaio de Filosofia Jurídica e Social, cit., p.159 e sgts).

No contexto do Direito Internacional dos Direitos Humanos e do Direito Internacional Penal, o princípio da complementariedade demonstra que cabe, primordialmente, aos Estados a proteção dos indivíduos, mas que, nos casos em que não consigam proteger seus interesses ou não queiram, a comunidade internacional vê-se incumbida da tarefa. Dessa forma, o princípio da complementariedade indica o fim do domínio reservado do Estado em questões que são mais valiosas para a humanidade. (gn) 


\section{5 - A PRESSÃo POLÍtica internacional PELA CARTA INTERNACIONAL DE DIREITOS HUMANOS}

Na introdução de seu livro, A Declaração Universal de Direitos Humanos - Origens, Redação e Intenção ${ }_{2}^{45}{ }_{2}$ Johannes Morsink pondera sobre a Declaração Universal de Direitos Humanos (DUDH1948) ${ }^{46}$ aos cinquenta com a seguinte constatação :

(...) É inevitável que um documento como a Declaração Universal dos Direitos Humanos deva levantar inquietações acerca da possibilidade de existirem valores universais. Essas inquietações começaram antes de o documento estar mesmo terminado, continua até o presente e provavelmente nunca terminará. (gn)

Relata-nos Johannes Morsink ${ }^{47}$ que, quando a Organização das Nações Unidas foi fundada em 1945, havia uma tremenda pressão sobre os delegados daquela conferência de fundação para incluir uma carta internacional de direitos humanos na Carta das Nações Unidas. As pressões nacionais e internacionais para a redação dessa carta tinham sido constituídas, de forma constante, durante a Segunda Guerra Mundial. Por volta de meados de 1944, diz o pesquisador da Guerra Fria Aruga Tadashi ${ }^{48}$, "o povo estadunidense" tinha "novamente abraçado o internacionalismo... que considerava a Organização das Nações Unidas ${ }^{49}$ como o cerne da nova ordem internacional". E Franklin

${ }^{45}$ MORSINK, Johannes, The Universal Declaration of Human Rights : Origins, Drafting and Intent, University of Pennsylvania Press, 1999.

${ }^{46}$ Em nota explicativa, a organização da Coletânea de direito internacional da editora Revista dos Tribunais faz o seguinte comentário sobre a natureza jurídica das resoluções onusianas :

"Embora não sejam, tecnicamente, tratados internacionais, essas declarações foram inseridas nesta coleção por serem textos memoráveis, reconhecidos internacionalmente como integrantes do direito costumeiro internacional".

Coletânea de direito internacional, organizador Valerio de Oliveira Mazzuoli. 4. ed.ampl. - São Paulo :Editora Revista dos Tribunais, 2006 - (Coleção RT Mini Códigos)

${ }^{47}$ MORSINK, Johannes, The Universal Declaration of Human Rights : Origins, Drafting and Intent, University of Pennsylvania Press, 1999.p.2

${ }^{48}$ MORSINK, Johannes, The Universal Declaration of Human Rights : Origins , Drafting and Intent, University of Pennsylvania Press, 1999.p.3.

${ }^{49}$ Paulo Portela detalha:

As negociações voltadas à criação da ONU começaram antes mesmo do fim da II Guerra. 
Roosevelt tinha se tornado tão ávido para tirar a nova organização internacional do papel que ele a fez seu item número um da agenda, quando se encontrou com Stalin na Conferência de Yalta. Primeiro, Stalin resistiu, mas um compromisso foi trabalhado. Conforme explica Daniel Yergin, "as grandes potências retiveram o veto no Conselho de Segurança (CSNU) e os líderes ocidentais concordaram em apoiar a admissão de dois ou três membros originários das Repúblicas Soviéticas". Duas dessas Repúblicas, a Bielorrussa e a Ucraniana, posteriormente, desempenharam uma função importante na elaboração da Declaração Universal.

Essa pressão para uma carta de direitos humanos não era apenas doméstica (EUA), pois, na Conferência Interamericana sobre a Guerra e a Paz, ocorrida na Cidade do México, entre fevereiro e março de 1945, vinte e um países americanos disseram que eles queriam ver uma carta de direitos humanos como parte da própria Carta da ONU que seria organizada em breve. Três nações latino-americanas (Cuba, Chile e Panamá) foram as primeiras a submeterem às Nações Unidas um rascunho para essa carta e, na Conferência de São Francisco em 1945, elas tentaram incluir a carta de direitos humanos na Carta da ONU. Seus esforços foram amplificados por intermédio de quarenta e seis grupos civis e religiosos, que o Secretário de Estado dos EUA, Edward Stettinius, tinha convidado à São Francisco para ajudar na fundação da ONU.

Toda essa pressão doméstica e internacional surtiu efeito, quando, em 4 de maio de 1945, o Secretário Stettinius aceitou a ideia de que a Carta das Nações Unidas devesse incluir, se não uma carta de direitos imediata e plena, então, certamente, referências explícitas à necessidade de reconhecimento internacional e de proteção dos direitos humanos.

Há sete referências explícitas que podem ser encontradas na Carta das Nações Unidas. No parágrafo de abertura, os povos das Nações Unidas reafirmam sua "fé nos direitos humanos fundamentais, na dignidade e no valor do ser humano, na igualdade de direito dos homens e das mulheres, assim como das nações grandes e pequenas. Os

Em 01-01-1942, foi firmada a Declaração das Nações Unidas, documento que reunia Estados que combatiam o eixo Alemanha-Japão-Itália. Em 1943, por ocasião da Conferência de Moscou, EUA, Reino Unido e URSS concluíram que a reorganização do mundo pós-guerra deveria contar com o aporte de uma organização fundada na igualdade soberana entre os Estados e voltada prioritariamente à manutenção da paz.

A proposta seria formatada por ocasião de reuniões em Durbarton Oaks (EUA), em 1944, e em Yalta (atual Ucrânia), em 1945, que serviram de base para a elaboração da Carta das Nações Unidas. 
povos das Nações Unidas também dizem que eles estão determinados a "promover o progresso social e melhores condições de vida dentro de uma liberdade mais ampla".Os redatores da DUDH1948 repetiram muito dessa linguagem na quinta consideração do próprio preâmbulo: "Considerando que os povos das Nações Unidas reafirmaram, na Carta, sua fé nos direitos humanos, na dignidade e no valor da pessoa humana e na igualdade de direitos do homem e da mulher, e que decidiram promover o progresso social e melhores condições de vida em uma liberdade ampla".

Além dessas três referências, Morsinsk demonstra que a referência de "progresso social" junto com a meta estabelecida no artigo 55, a, para promover "níveis mais altos de vida, pleno emprego e condições de progresso socioeconômico e desenvolvimento", foram usadas para ajudar na inclusão dos direitos econômico, sociais e culturais na DUDH1948.

No parágrafo 3 do artigo 1 da Carta da ONU, os fundadores repetiram o mesmo tipo de linguagem e de compromisso. Eles afirmaram que um dos propósitos da $\mathrm{ONU}^{50}$ é o de "conseguir uma cooperação internacional para resolver os problemas internacionais de caráter econômico, social, cultural ou humanitário, e para promover e estimular o respeito aos direitos humanos e às liberdades fundamentais para todos sem distinção de raça, sexo, língua ou religião". O mesmo tipo de lista é repetido, novamente, quando o artigo 13 da Carta afirma que "A Assembleia Geral (AGNU) iniciará estudos destinados a favorecer o pleno gozo dos direitos humanos e das liberdades fundamentais, por parte de todos os povos, sem distinção de raça, língua ou religião. Muitos dos estudos

$50 \quad$ Para Amaral Júnior:

"a constituição da ONU engendrará um novo modelo internacional, fundado não só na soberania estatal, mas também na restrição do uso da força, na solução pacífica de controvérsias e no respeito aos cidadãos".

Paulo Portela observa, também, que a ONU, pelo amplo escopo de sua atuação, marca o início de um período em que o Direito Internacional deixa de ser um mero fator de equilíbrio entre os Estados, tutelando apenas questões estratégicas, e passa a tratar de um número cada vez maior de atores.

Por fim, a ONU veio a consolidar uma série de noções fundamentais para as relações internacionais da atualidade, como a autodeterminação dos povos, a proibição do uso da força nas relações internacionais, a solução pacífica de controvérsias e a atribuição de prioridade à proteção dos direitos humanos.

Com isso, podemos afirma que a ONU é uma das referências da emergência de um Direito comum a todos os membros da espécie humana, ou mesmo do aparecimento de um "Direito transnacional", que disciplina tudo aquilo que transcende as fronteiras dos entes estatais, abrangendo o comportamento do Estado, dos indivíduos e das próprias organizações internacionais.

in PORTELA, Paulo Henrique Gonçalves. Direito Internacional Público e Privados, incluindo noções de direitos humanos e de direito comunitário. 3 ed. , editora juspodium. p.243. 


\section{iniciais foram feitos, especificamente, para ajudar a Comissão de Direitos Humanos a redigir uma carta internacional.}

$\mathrm{O}$ artigo 62, parágrafo 2, da Carta da ONU diz que "o Conselho Econômico e Social (ECOSOC) ${ }^{51}$ poderá fazer recomendações destinadas a promover o respeito e a observância dos direitos humanos e das liberdades fundamentais para todos"..O ECOSOC usou desse poder, quando ele recomendou, em 10 de dezembro de 1948, que a Terceira Assembleia Geral da ONU adotasse e promulgasse a Declaração Universal de Direitos Humanos. No artigo 68, a Carta da ONU estabelece que o próprio ECOSOC "criará comissões para os assuntos econômicos e sociais e a proteção dos direitos humanos". Esse artigo demonstra que o Conselho Econômico e Social não tinha escolha, a não ser constituir uma Comissão de Direitos Humanos ${ }^{52}$ que redigiria a Declaração.(gn)

51 O ECOSOC é composto por cinquenta e quatro membros das Nações Unidas, eleitos pela AGNU para um mandato de três anos, permitida a reeleição para o período subsequente, com a eleição de dezoito membros por ano.

Ele é competente para fazer estudos e relatórios a respeito de assuntos internacionais de caráter econômico, social, cultural, educacional, sanitário e conexos, como o desenvolvimento, e para promover a observância dos direitos humanos. Nesse sentido, o ECOSOC pode fazer recomendações a respeito desses temas à Assembleia Geral, aos membros das Nações Unidas e às entidades especializadas interessadas ou apresentar projetos de tratados internacionais referentes a essas matérias.

Ele tem, ainda, a missão de coordenar as atividades dos organismos especializados do Sistema das Nações Unidas. Por fim, sua estrutura específica inclui as comissões necessárias ao desempenho de suas funções, como a CEPAL (Comissão Econômica para a América Latina e o Caribe) in PORTELA, Paulo Henrique Gonçalves. Direito Internacional Público e Privados, incluindo noções de direitos humanos e de direito comunitário. 3 ed. , editora juspodium p.249.

52 A Comissão de Direitos Humanos das Nações Unidas (CDH) foi criada em 1946 com o objetivo de promover e de contribuir para as negociações de tratados de direitos humanos e de servir de foro para discussões na matéria.

Além de ter exercido função muito relevante na elaboração dos principais tratados de direitos humanos do Sistema Global, a Comissão de Direitos Humanos era também notória pelo sistema de "relatores especiais" (special rapporteurs) também conhecidos como "Representantes Especiais do Secretário-Geral" ou" Especialistas Independentes".

O Conselho de Direitos Humanos da ONU foi criado em 2006 pela resolução 60/251 da Assembleia Geral das Nações Unidas para substituir a antiga Comissão de Direitos Humanos.

Ao contrário da Comissão, que era composta por representantes de 53 Estados-membros da ONU eleitos pelo ECOSOC, divididos segundo o critério de repartição geográfica, o Conselho é vinculado à AGNU e é composto por representantes de 47, eleitos pelos membros da AGNU. O Conselho herdou da Comissão o mecanismo dos "procedimentos especiais", que são objeto de um mandato conferido a um especialista, chamado de "relator especial", ou a um grupo de trabalho, competentes para examinar transgressões das normas de direitos humanos e para elaborar estudos e relatórios e emitir recomendações a esse respeito, podendo receber reclamações individuais, prestar assessoria aos interessados e formular e executar iniciativas dirigidas à promoção dos direitos humanos. in PORTELA, Paulo Henrique Gonçalves. Direito Internacional Público e Privados, incluindo noções de direitos humanos e de direito comunitário. 3 ed., editora juspodium. p. 757. 
Ainda segundo Morsink ${ }^{53}$, a Comissão de Direitos Humanos era a única comissão de todo o sistema onusiano que era autorizada pela Carta da ONU, o que demonstra quão importante era para os fundadores da ONU a causa da proteção e do reconhecimento dos direitos humanos.(gn)

Essa longa lista de citações demonstra que a DUDH1948 era uma extensão e uma explicação daquelas referências aos direitos humanos na Carta da ONU, que, entretanto, não autorizava, em nenhum ponto, que uma carta internacional de direitos humanos fosse escrita. A Carta da ONU autorizava o estabelecimento de uma Comissão de Direitos Humanos, e não se referia ao caso de uma carta internacional, para que sua redação fosse entendida de modo tácito. No final da Conferência de São Francisco, o presidente estadunidense, Harry Truman, destacou essa situação de forma explícita. Ao tornar-se presidente, Harry Truman assumiu, integralmente, o projeto das Nações Unidas de Roosevelt.

Ele exortou os delegados para que se concentrassem na produção de uma carta para a nova organização e prometeu-lhes que "de acordo com esse documento, nós temos boas razões para esperar a positivação de uma carta internacional de direitos humanos, aceitável para todas as nações envolvidas". Essa carta de direitos, prediziu Truman, " fará parte da vida internacional, assim como nossa Carta de Direitos é parte da nossa Constituição".

A promessa de Truman foi mantida, quando o Conselho Econômico e Social afirma que: "tendo sido encarregado, de acordo com a Carta da ONU, com a responsabilidade de promover respeito universal e observância dos direitos humanos e da liberdades fundamentais... Estabelece a Comissão de Direitos Humanos" e a encarrega, primeiramente, de elaborar uma recomendação e um relatório "considerando... uma carta de direitos humanos internacional". A CDH, tendo sido constituída e dada como tarefa a redação de uma carta internacional de direitos, trabalhou nesse projeto por 2 anos inteiros, de janeiro de 1947 a dezembro de 1948, quando a Terceira Assembleia Geral adotou o que ela denominou de Declaração Universal de Direitos Humanos ${ }^{54}$.

${ }^{52}$ MORSINK, Johannes, The Universal Declaration of Human Rights : Origins, Drafting and Intent, University of Pennsylvania Press, 1999. p. 10.

${ }^{53}$ ibidem. p.3.

${ }^{54}$ ibidem, p. 4 
Em 1947, a, então, Comissão de Direitos Humanos da Organização das Nações Unidas, órgão responsável pela redação da DUDH1948, recebeu um longo memorando da Associação Americana de Antropologia (AAA). Essa associação estava preocupada com o problema de etnocentrismo (considerar os valores de uma cultura superior aos valores de outras culturas). Nesse sentido, Johannes Morsink pondera ${ }^{55}$ :

É difícil de evitar fazer julgamentos etnocêntricos, porque crescemos com valores de nossa própria sociedade ou grupo, e quase nunca paramos para analisá-los. Esse processo de aculturamento ${ }^{56}$, conforme a AAA disse à Comissão de Direitos Humanos $(\mathrm{CDH})$, é tão sutil e seus efeitos tão extensos, que somente após treino considerável nos tornamos consciente dele.

Os antropologistas acreditavam que a Comissão de Direitos Humanos estava arriscando fazer julgamentos etnocêntricos na Carta Internacional de Direitos Humanos. Conforme a AAA observava, "a tarefa primeira" que os redatores enfrentavam era como encontrar uma solução para o seguinte problema: "Como pode a Declaração proposta ser aplicável para todos os seres humanos, e não ser uma afirmação de direitos concebidos somente em termos dos valores prevalecentes nos países europeus e nos Estados Unidos da América? A associação tinha receios de que esse problema não tivesse solução.

Os antropologistas destacaram três proposições para a CDH ponderar: (i) O indivíduo concebe sua personalidade por meio de sua cultura, assim, respeitar diferenças

\footnotetext{
55 MORSINK, Johannes, The Universal Declaration of Human Rights : Origins, Drafting and Intent, University of Pennsylvania Press, 1999. p. 10.

${ }^{56}$ definição aculturamento:1.Antrop. Processo decorrente do contato mais ou menos direto e contínuo entre dois ou mais grupos sociais, pelo qual cada um desses grupos assimila, adota ou rejeita elementos da cultura do outro, seja de modo recíproco ou unilateral, e podendo implicar, eventualmente, subordinação política. 3. Psicol. Adaptação de um indivíduo a uma nova cultura com que estabelece contato, seja em seu local de origem, seja em outro local de origem, seja em outro local para que se tenha mudado. 4.Sociol. Formação de uma nova cultura com base na absorção de um cultura por outra. in HOUAISS, Antônio e VILLAR, Mauro de Salles, Minidicionário Houaiss da língua portuguesa - 2 ed. rev. e aum - Rio de Janeiro : Objetiva, 2004. ISBN 85-7302-623-5 (DHou)
} 
individuais implicam respeitar diferenças culturais; (ii) respeitar diferenças entre culturas é válido pelo fato científico de que nenhuma técnica de avaliação qualitativa de culturas foi descoberto; (iii) Padrões e valores relativos à cultura da qual eles derivam qualquer tentativa de formular postulados que estejam fora dos códigos moral e de credo de uma cultura devem diminuir a aplicabilidade de qualquer Declaração de direitos humanos à humanidade naquela extensão. Por trás dessas proposições está a convicção de que "o que se considera um direito humano em uma sociedade pode ser visto como antissocial por outras pessoas em um diferente período da história delas". (gn)

Dependendo de como interpretamos a frase "naquela extensão" na terceira proposição, ou a Comissão de Direitos Humanos era perguntada para ser extremamente cuidadosa para não recomendar valores ocidentais meramente, ou era delicadamente informada de que ela estava tentando algo impossível e que a tarefa que lhe havia sido dada pelo Conselho Econômico e Social (ECOSOC) não poderia ser feito.

Os redatores da DUDH1948 pensavam, evidentemente, de outra forma. Uma vez que eles foram adiante, apesar dos alertas da AAA, eles devem ter pensado que eles tinham encontrado uma forma de comparar qualitativamente sistemas de valores diferentes que formavam diferentes estilos de vida e mesmo culturas inteiras. O que eles produziram mudou, profundamente, o contexto internacional, dispersando nele protocolos de direitos humanos, convenções, tratados e declarações derivativas de todos os tipos. No final do século XX e início do XXI, não existe uma única nação, cultura ou povo que não está de um jeito ou de outro enredado no "Sistema Global de Proteção dos Direitos Humanos".(gn)

Ensina-nos, textualmente, Paulo Henrique Portela os conceitos básicos do Direito Internacional dos Direito Humanos (DIDH) :

é o ramo do Direito Internacional que visa a proteger e a promover a dignidade humana em todo o mundo, consagrando uma série de direitos dirigidos a todos os indivíduos de qualquer espécie, inclusive de nacionalidade ou de Estado onde a pessoa se encontre. 
A importância do DIDH no atual contexto internacional, pós Segunda Guerra Mundial, parte da percepção de que a proteção da dignidade humana foi alçada a interesse "comum superior de todos os Estados" e passou a ter o caráter de valor que se reveste de primazia diante de outros bens jurídicos. Com isso, as normas internacionais de direitos humanos adquirem relevância tal que passam a constitui um verdadeiro "imperativo superior de proteção da pessoa" ${ }^{57}$ com o qual devem se comprometer todos os membros da sociedade internacional em caráter prioritário. Com isso, as normas internacionais de direitos humanos assumem status de prevalência, devendo ser aplicadas antes de qualquer outra, limitando a própria soberania nacional, e passando a ser incluídas dentre os preceitos de jus cogens. (gn)

O objeto do Direito Internacional dos Direitos Humanos é, portanto, a promoção e a proteção da dignidade humana em caráter universal. Seu fundamento é, essencialmente, a convicção, amplamente difundida na sociedade internacional, quanto à importância de resguardar a dignidade humana, não só pelo valor inerente à pessoa, como também pelo entendimento de que a paz requer o respeito aos direitos humanos. (gn)

O DIDH é um ramo do Direito das Gentes, ao qual se aplicam, portanto, alguns dos institutos do Direito Internacional. A título de exemplo, suas normas encontram-se, em geral, consagradas em tratados cuja inclusão requer a anuência de Estados e de organizações internacionais; entretanto, a importância atribuída aos direitos humanos vem levando a que sua obrigatoriedade venha paulatinamente se impondo, independentemente da vontade dos Estados, mormente pelo reconhecimento de suas normas, como costume, princípios gerais

${ }^{57}$ CANÇADO TRINDADE, Antônio Augusto. Tratado de direito internacional dos direitos humanos, v.1, p.415-416. 
do Direito ou jus cogens ou, ainda, pelo soft law. "58.

A proteção internacional dos direitos humanos estrutura-se ao redor de sistemas, ou seja, de esquemas compostos por tratados e por órgãos encarregados de acompanhar a aplicação e velar pela execução de suas normas. Há dois tipos de sistemas internacionais de proteção dos direitos humanos : o global e os regionais.

O Sistema Global de Proteção dos Direitos Humanos, também conhecido como "internacional" ou "universal", visa a abranger o mundo inteiro. É administrado principalmente pela Organização das Nações Unidas (ONU), dentro da qual é negociada a maioria de seus tratados e em cuja estrutura se encontra órgãos competentes para monitorar o cumprimento desses compromissos internacionais e exigir o cumprimento de suas normas. Seus documentos mais importantes são a DUDH1948, os Pactos sobre Direitos Civis e Políticos e sobre Direitos Econômicos, Sociais e Culturais, ambos de 1966, o que em conjunto formam a Carta Internacional de Direitos Humanos da ONU ${ }^{59}$.

Na Conferência sobre a Guerra e a Paz de fevereiro de 1945, a Guatemala declarou que a II Guerra Mundial tinha criado uma demanda global que os direitos do homem deveriam ser reconhecidos e protegidos em nível internacional, e que o movimento interamericano, portanto, deveria apoiar esse anseio por meio do reconhecimento segundo o qual regimes antidemocráticos eram a causa primária de negação dos direitos humanos e das liberdades.

Na conferência de São Francisco onde as Nações Unidas estavam sendo organizadas, as nações latino-americanas juntaram-se a numerosas organizações não governamentais e fizeram vigorosos lobbies, mas não exitosos, para a inclusão de uma carta de direitos na Carta das Nações Unidas.

Morsink relata-nos que, no final dos anos 1940, os apoiadores dos direitos humanos tiveram de lutar por legitimidade intelectual, uma batalha que eles finalmente ganharam em razão dos horrores perpetrados pelos nazistas. Agora, conforme o documento está prestes a chegar aos seus setenta anos, os críticos têm de se posicionar em face de um fato-axiológico de extraordinário êxito que a DUDH1948 se tornou.

\footnotetext{
58 PORTELA, Paulo Henrique Gonçalves. Direito Internacional Público e Privados, incluindo noções de direitos humanos e de direito comunitário. 3 ed. , editora juspodium p. 701/702.

${ }^{59}$ PORTELA, Paulo Henrique Gonçalves. Direito Internacional Público e Privados, incluindo noções de direitos humanos e de direito comunitário. 3 ed., editora juspodium.p.713
} 
Hurst Hannum ${ }^{60}$ fez uma pesquisa sobre o estado da arte da Declaração nos direitos doméstico e internacional no início dos anos 1990. Sua sentença de abertura reconhece a profunda influência da Declaração : "A Declaração Universal de Direitos Humanos tem sido a fundação de muito da codificação de direitos humanos após 1945, e o " Sistema Global de Proteção dos Direitos Humanos" está repleto de tratados globais e regionais baseados, em larga medida, na DUDH1948. Hannum fundamenta sua alegação com uma lista de cinquenta (sic) instrumentos internacionais de direitos humanos que fazem referência à ela, bem como pode ser dito que foram inspiradas pela DUDH1948. Verifica-se que, muito embora não houvesse nenhum mecanismo de implementação, a adoção, em 1948, da Declaração foi exitosa em razão de ela transcender todas as contingências locais e regionais e de ela afirmar princípios e direitos morais mais ou menos abstratos. A falta de medidas de implementação fez da DUDH1948 uma espécie de parteira para a nascimento de todos os outros instrumentos internacionais concretos e mais detalhados, como os Pactos de 1966.

${ }^{60}$ MORSINK, Johannes, The Universal Declaration of Human Rights : Origins, Drafting and Intent, University of Pennsylvania Press, 1999. p12 


\title{
1.6.1 - A DECLARAÇÃO UNIVERSAL COMO MODELO $^{61}$ JURÍDICO PRESCRITIVO $^{62}$
}

\author{
Segundo Morsink ${ }^{63}$,
}

a persistente alegação de etnocentrismo é, em parte causada, pelo fato de pouquíssimas pessoas saberem o que foi dito e feito durante o processo de elaboração. Essa ignorância levou a inúmeras incompreensões sobre como o documento foi redigido e o que ele e suas partes significam.

É minha esperança que esse livro ajudará a fazer um diálogo contínuo sobre a DUDH1948 mais informado por meio da exposição dos fatos relativos ao processo de redação. Talvez os críticos possam atenuar suas dúvidas normativas restantes com base no pleno conhecimento do que foi dito por quem, quando e porque.

Como um trabalho de pesquisa histórica, essa história da redação da DUDH1948 é de tipo interno. À exceção das óbvias conexões com a Segunda Guerra Mundial, a Guerra Fria e o Socialismo Latino Americano, fiz poucas tentativas de relacionar episódios específicos do processo decisório a tópicos externos específicos naquele tempo. Essa limitação veio muito naturalmente, pois (com as mesmas exceções), os próprios redatores-autores concentraram-se em suas tarefas e quase nunca trouxeram eventos mundiais específicos à mesa de negociações. Essa disciplina é devida em grande medida pela

\footnotetext{
${ }^{61}$ REALE, Miguel. Teoria Tridimensional do Direito, situação atual, 5 ed. rev. e aum. - São Paulo: Saraiva, 1994, p.105/107.

${ }^{62}$ REALE, Miguel. Teoria Tridimensional do Direito, situação atual, 5 ed. rev. e aum. - São Paulo: Saraiva, 1994, p12. Explica-nos o jurista: Prescritivos são os modelos jurídicos, os quais se estruturam como integração de fatos e valores segundo normas postas em virtude de um ato concomitante de escolha e de prescrição (ato decisório) que pode ser tanto do legislador ou do juiz, bem como resultar de opções costumeiras ou de estipulações fundadas na autonomia da vontade. Tais modelos (legais, jurisdicionais, consuetudinários e negociais) distinguem-se por seu sentido vetorial e prospectivo, ao contrário do sentido retrospectivo das chamadas 'fontes formais'.(gn)

${ }^{63}$ MORSINK, Johannes, The Universal Declaration of Human Rights : Origins, Drafting and Intent, University of Pennsylvania Press, 1999. p.xiii
} 
autoridade moral que Eleanor Roosevelt exerceu como presidenta da Comissão de Direitos Humanos responsável pela redação da Declaração. (gn)

Com a ajuda de inúmeras citações dos arquivos da ONU, eu explico porque o texto da Declaração Universal é lido do modo que está - porque certos direitos ou cláusulas foram incluídas e outras deixadas de lado. Eu refiro-me a quem e qual delegado disse o que, quando e porque. Blocos de votação a favor e contra certos direito são fornecidos, quase sempre com o placar da votação para que o leitor e a leitora possam dizer, se uma cláusula ou um artigo foram aceitos com pequena margem ou rejeitados e por quem e quais razões. Ao também me reportar sobre as emendas mais importantes que foram rejeitadas, eu espero dar ao leitor um senso de importância daqueles debates e do idealismo e da excitação que estavam presentes nos primeiros anos da ONU, antes que o realismo e o cinismo firmassem suas raízes.

Essas citações dos arquivos formam a maior parte da exposição sobre a nomogênese do direito à alimentação na DUDH1948. Segundo Morsink, o processo de elaboração da Declaração durou dois anos e foi muito inclusivo, pois foi composto por sete etapas negociais distintas, além do fator crucial do Holocausto, cuja rejeição moral compartilhada dos delegados contra esse evento foi o principal motivador da redação da DUDH1948. A presença dos direitos econômicos, culturais e sociais na Declaração provavelmente virá como uma grande surpresa para muitos leitores.

Em cada capítulo referente aos DESC, diz Morsink, eu revelo a forte influência do socialismo Latino-Americano no processo de elaboração e seu resultado. Essa é uma das incompreensões que essa história nomotética esclarece, pois não foram os comunistas, mas os socialistas latino-americanos - e John Humphrey como condutor deles - aqueles que devemos a 
presença desses direitos na Declaração. ${ }^{64}$

Além disso, explico que os autores faziam, de fato, uma distinção entre os "antigos" direitos humanos civis e políticos do século XVIII e os "novos" direitos econômicos, sociais e culturais dos séculos XIX e XX.. Saliento que, para a maioria absoluta dos autores, esse distinção era benigna. Quase todos eles pareciam acreditar que há uma unidade fundamental em todos os direitos humanos, o que eles expressaram como a seguinte expressão: "unidade orgânica" da Declaração. Com isso, eles queriam dizer que cada artigo da Declaração deve ser interpretado à luz de todo o restante, e especialmente à luz dos outros direitos do mesmo tópico ou do mesmo tema, e não necessariamente em termos do seu lugar exato na sequência final. Para os delegados-autores da Declaração, não havia dois tipos de cidadãos no reino dos direitos morais.(gn)

Nenhum dos tópicos ou temas anunciados foram tratados pelos redatores em apenas um ou dois artigos. Eles são todos temas básicos do documento inteiro.

${ }^{64}$ MORSINK, Johannes, The Universal Declaration of Human Rights : Origins , Drafting and Intent, University of Pennsylvania Press, 1999. p.xiv 


\subsection{2 - O PREÂMBULO DA DECLARAÇÃO E OS DIREITOS MORAIS $^{65}$}

Morsink chama-nos a atenção para o fato de:

Mesmo o leitor casual da Declaração Universal verá que existe uma similaridade de linguagem entre este documento das Nações Unidas de 1948 e as declarações clássicas do século XVIII. Essa similaridade é, especialmente, marcante no começo do documento.

A primeira consideração do Preâmbulo fala de "dignidade inerente" e de "direitos iguais e inalienáveis", ambas frases que recordam as formas de pensar do Iluminismo. A Declaração de Direitos de Virgínia de 1776 diz que "todos os homens são, por natureza, livres e independentes, e têm certos direitos inerentes", enquanto a Declaração Americana de Independência afirma que é "autoevidente que todos os homens são criados iguais" e "dotados pelo seu criador de certos direitos inalienáveis". A Declaração Francesa de 1789 usa da mesma linguagem, falando de direitos como "naturais, imprescritíveis, e inalienáveis".

Essas similaridades línguísticas no Preâmbulo criam uma presunção de que os autores da Declaração Universal tinham uma perspectiva iluminista dos direitos humanos ou dos direitos naturais como, de alguma forma, espalhados nos seres humanos simplesmente por virtude da própria humanidade deles e por nenhuma outra razão externa, como convenções sociais, atos de governos ou decisões parlamentares ou judiciais. Antes do final do processo de elaboração, o representante francês, René Cassin, confirmou essa suspeita, quando ele disse à AGNU que "em comum com a Declaração de 1789, a Declaração Universal de Direitos Humanos estava fundada nos princípios de liberdade, de igualdade e de fraternidade".

Mesmo os delegados comunistas, às vezes, enganavam-se, conforme ocorreu na proposta iugoslava que apoiava a prática de "estabelecer, como direitos inerentes em todo ser humano, o princípio da liberdade de associação sindical". Bem no

${ }^{65}$ MORSINK, Johannes, The Universal Declaration of Human Rights : Origins, Drafting and Intent, University of Pennsylvania Press, 1999. p 290 e sgts. 
início dos procedimentos de elaboração, a delegação indiana submeteu sua versão de uma carta internacional, que começou com a seguinte frase: "Reconhecendo o fato de que as Nações Unidas foram estabelecidas com o propósito específico de valorizar os direitos do homem".

Essas citações fortalecem a presunção, criada pelo texto, de que há um tipo de conexão entre a Declaração Universal e o modo iluminista de pensar sobre a moralidade. Exploraremos tanto as diferenças quanto as semelhanças.

Uma das vantagens de considerar os direitos humanos como direitos naturais dados a nós pela Natureza de Deus ou pela Natureza é que os torna mais fácil de serem considerados como universais e, portanto, tidos por todas as pessoas. Inversamente, uma vez que os redatores não usaram, expressamente, nem a palavra "natureza" nem a frase "natureza humana" como a fundação dos direitos na Declaração, o rótulo e o título de "direitos humanos" encaixa-se no texto e nos debates de forma muito mais apropriada do que a designação clássica de direitos naturais. Essa nova frase sintetiza os mesmos pontos sem quaisquer bagagens metafísicas extras que vinham anexas às conversações de direitos naturais. Uma consequência dessa demoção da Natureza é que nós devemos abordar esses termos iluministas chaves, como inalienável, inerente e nascido, dentro do enquadramento da tradição racionalista ocidental. Os redatores da Declaração vieram de uma grande variedade de tradições ideológicas e filosóficas - enquanto a maioria via os direitos fundamentados na natureza humana - e eles não pensavam que os direitos estavam anexos a nenhuma característica particular ou conjunto de característica. Os críticos que interpretam as frases iluministas da abertura da Declaração de um modo essencialista, racionalista ou deísta abordam de maneira muito restrita a Declaração Universal.

A estrutura geral do Preâmbulo é pragmática, no sentido de que os direitos ali proclamados são meios que visam à obtenção da paz mundial e de relações amistosas entre os Estados, no entanto, as duas primeiras considerações põem limites nesses cálculos para a paz mundial e o bem-estar da humanidade, porque, nessas considerações preambulares, os direitos humanos são tratados como fins em si mesmos. A lição é a de que os direitos humanos não podem servir como meios para algo, ao menos que eles sejam pensados como fins em si mesmos, o que é como os redatores pensavam dos direitos humanos na maioria do tempo.

Apesar de termos importantes do Iluminismo, como "inalienável" e "inerente", terem sido usados esporadicamente nos debates, o primeiro considerando não 
foi introduzido no texto da Declaração até muito tarde durante o processo de redação. Um Comitê sobre o Preâmbulo, composto de oficiais da Comissão de Direitos Humanos, propôs, pela primeira vez, as considerações na Terceira Sessão entre Maio e Junho de 1948. O Comitê era composto por Eleanor Roosevelt dos Estados Unidos (presidenta), P.C.Chang da China (vice-presidente), René Cassin da França (vice-presidente) e Charles Malik do Líbano (relator e secretário executivo). Todas as quatro delegações apoiavam (em graus variados) a perspectiva dos direitos humanos inerentes e, não nos deveria causar surpresa o fato dessas frases nunca terem sido seriamente questionadas, nem mesmo no Terceiro Comitê, que examinou tudo com um pente fino. Mesmo as delegações comunistas se esqueceram de votar contra ou de abster-se, pois, no Terceiro Comitê. essa primeira consideração preambular foi adotada unanimemente.

A doutrina da inerência que atribuímos aos redatores-autores conflita com a interpretação que Tore Lindholm dá ao artigo 1 da Declaração. Lindholm sabe, por certo, que a perspectiva da inerência é a forma mais natural de ler as frases de abertura da Declaração. Ele sugere que os "defensores da interpretação dos direitos naturais da Declaração" podem responder que qualquer doutrina moral ou legal pré-estatal ou prépositivada de direitos humanos validos é uma doutrina de direito natural por definição. Enquanto isso não seja um chauvinismo cultural míope, a inerência é, diz Lindholm, "uma versão diluída de algo genuíno, de acordo com o qual os direitos naturais podem ser vistos como conclusões de um argumento, cujas premissas propõem aspectos pertinentes [...]da natureza humana".

Ao não trabalhar com essências e argumentos dedutivos, a doutrina da inerência simples que atribuímos aos redatores é, de fato, uma "versão diluída" do que supostamente seja uma coisa "real".

Os redatores compartilhavam com os seus predecessores iluministas a alegação crucial de que o Direito (positivo) não é, conforme Thomsom coloca, "uma condição necessária para se ter demandas (morais). Há alegações de que nós, no nosso mundo, somos incumbidos pela lei, mas que nós seriamos incumbidos da mesma forma, mesmo se não existisse lei para tanto". A DUDH1948 contém um bom número desses direitos morais. As pessoas têm direitos morais que restringem o comportamento dos outros e esses direitos são inerentes a elas, uma vez que eles não decorrem de atos alheios, como os de governos, de cortes, ou mesmo de convenções sociais. Os Redatores acreditavam que as pessoas já começavam suas vidas, possuindo certos direitos morais, o 
direito à vida sendo apenas um entre eles.

A definição não tradicional ou não racionalista (e, portanto, minimalista) dos direitos inerentes como pré-estatais ou pré-positivos não deve cegar-nos à distinção crucial entre direitos legais e morais. Os redatores entendiam essa distinção e trabalharam com ela. As pressões do tempo e da Guerra Fria impediram a finalização e a adoção de um pacto em 1948. A maioria dos redatores viu essa não realização como um revés, mas, ao invés de desistir da ideia de uma carta de direitos, os autores seguiram em frente e proclamaram uma carta de direitos morais somente, na esperança de que a maquinaria de implementação legal seguisse em breve. Os discursos dos delegados deixam evidente esse posicionamento de que eles sentiam nenhum remorso sobre a proclamação de uma lista com apenas direitos morais. De fato, o Instituto Internacional de Direito tinha encorajado os diplomatas a fazerem dessa maneira.(gn)

Roosevelt acreditou, o tempo todo, que "a declaração não seria legalmente vinculante sobre os governos", o que é uma das razões do país dela querer uma mera declaração, mas ela argumentou, junto ao Terceiro Comitê, que essa falta de força legal "tornava ainda mais necessário redigir um preâmbulo que exercesse sobre os governos a maior força de persuasão em termos morais". Frede Castberg, o delegado da Noruega, também notou que a Declaração foi designada para "estabelecer padrões morais ao invés de obrigações legais". Corominas, o delegado argentino, seguiu a mesmo raciocínio ao comentar que a Declaração "envolvia somente obrigações morais, e deveria ser seguida por um documento que impusesse obrigações legais".

Mesmo Cassin, que frequentemente realçava que a Declaração era "uma interpretação categórica da Carta das Nações Unidas", admitiu que ela "não teria força jurídica coercitiva". E C.H. Wu, o delegado chinês na Primeira Sessão de Elaboração, "mantinha que a declaração poderia servir, somente, como um padrão moral em relação ao qual a humanidade aspira". Juliusz Katz-Suchy, o delegado polonês que se absteve da votação final, admitiu, momentos antes de tê-lo feito, que a Declaração tinha força moral. Ele disse que "a declaração do modo apresentado era somente uma expressão de princípios, com nenhuma provisão para implementação e apenas com valor moral"

A perspectiva de que a Declaração Universal de Direitos Humanos não tinha força coercitiva, mas apenas força moral era a opinião quase unânime das delegações envolvidas no processo de redação. Há uma tremenda força moral e filosófica nessa posição, e ela explica o porquê a Declaração tornou-se o referencial moral tanto no mundo 
dos indivíduos quanto no dos Estados.

É precisamente o fato de esses direitos serem inerentes às pessoas, $\mathrm{e}$ não presente da história ou das circunstâncias, que eles podem ser usados como padrões os quais tanto a história quanto as circunstâncias poderão ser julgados. (gn) 


\section{7 - AS SETE ETAPAS DO PROCESSO DE ELABORAÇÃO ${ }^{66}$ OU O RITO DAS PROPOSIÇÕES NORMATIVAS}

Em abril e maio de 1946, o Comitê Nuclear (preparatório) encontrou-se para fazer recomendações ao Conselho Econômico e Social com respeito à forma e às tarefas da Comissão de Direitos Humanos que o Conselho tinha mandado criar. Esse Comitê Nuclear recebeu do ECOSOC os primeiros rascunhos para uma carta internacional submetidos por muitas nações latino-americanas. Ele decidiu, por sua vez, que "enquanto estava dentro de suas competências o rascunho de uma carta de direitos humanos, o Comitê ainda não estava em condições de fazê-lo, mas que prosseguiria com o trabalho preparatório"(E/38/Rev.1/p.3).

Como parte de sua preparação, o Comitê ouviu inúmeras organizações não governamentais sobre o tema de direitos humanos e das liberdades. Ele recomendou que o número de membros da Comissão de Direitos Humanos (CDH) fosse 18, e que esses membros "servissem como representantes não governamentais", e que uma "nação pudesse patrocinar um candidato de outra nação membro" (E/38/Rev.1/p.9). Ambas sugestões foram rejeitadas, porque o ECOSOC sentia que esses 18 membros devessem ser representantes oficiais e que eles deveriam falar por seus países. Essa decisão aumentou tanto a solenidade quanto a universalidade do processo de redação.

Essa universalidade também aumentou com a sugestão do Comitê Nuclear de que o Conselho Econômico "devesse, todo o tempo, prestar atenção à distribuição geográfica equitativa e às qualificações pessoais dos nomeados para o serviço na CDH" (E/HR.9/p.5). O ECOSOC seguiu esse conselho, quando ele apontou as seguintes nações para servirem na Comissão de Direitos Humanos que produziria a Declaração: Austrália, Bélgica, República Socialista Soviética da Bielorússia (BSSR), Chile, China, Egito, França, Índia, Irã, Líbano, Panamá, República Filipina, Reino Unido, Estados Unidos da América, União das Repúblicas Socialistas Soviéticas, Uruguai e Iugoslávia.

Em junho de 1946, o Conselho Econômico demandou uma carta de direitos dessa Comissão de Direitos Humanos, quando ela fosse ativada, o que ocorreu em janeiro de 1947.

${ }^{66}$ MORSINK, Johannes, The Universal Declaration of Human Rights : Origins , Drafting and Intent, University of Pennsylvania Press, 1999. p.4/12. 
Nesse ponto, Morsink explica sua metodologia:

Começo a contar 7 etapas de negociação do processo decisório. Elas consistem em: (1) a Primeira Sessão da Comissão, (2) a Primeira Sessão do Comitê de Elaboração que a CDH criou, (3) a Segunda Sessão da Comissão, (4) a Segunda Sessão do Comitê de Elaboração, (5) a Terceira Sessão da Comissão, (6) o Terceiro Comitê da Assembleia Geral, (7) a Sessão Plenária da mesma Assembleia em 1948.

\section{$\underline{\text { Etapa } 1}$}

A Primeira Sessão da CDH reuniu-se em janeiro e fevereiro de 1947. Assim que os delegados começaram a discutir a maquinaria para a elaboração de uma carta de direitos internacionais, o objeto levantado na discussão era se a elaboração da Declaração devesse ser confiado a um comitê ou ao Secretariado da ONU. Decidiu-se que " a Presidenta da Comissão de Direitos Humanos junto com o Vice-Presidente e o Relator Especial, assumiriam, com a assistência do Secretariado, a tarefa de formular uma carta internacional preliminar de direitos humanos". Também foi concordado que esse grupo executivo - presidenta, vice-presidente e relator especial - poderia consultar quaisquer membros da Comissão de Direitos Humanos e especialistas" escolhidos com o consentimento dos governos deles, membros das Nações Unidas" (SR.12/p.5). Essa última limitação foi, posteriormente, removida, quando o grupo de rascunho recebeu a autorização de "consultar qualquer documento ou pessoa, considerados pelo grupo, relevantes para o trabalho dele" (SR.18/p.2).

O grupo executivo teve um encontro, no qual John P. Humphrey, recentemente nomeado Diretor da Divisão de Direitos Humanos do Secretariado, também compareceu. Humphrey relata que "era típico da sra. Roosevelt querer que o comitê elaborador começasse a trabalhar o mais rápido possível e, por isso, ela convidou dois colegas dela e eu para reunirmos com ela em seu apartamento da Washignton Square no domingo seguinte ao encontro", em que Humphrey foi convidado para preparar um rascunho da Declaração. Esse encontro ocorreu em 17 de fevereiro de 1947. 
Escreve Humphrey :

Peng-Chun Chang (China) e Charles Habib Malik (Líbano) estavam muito distantes em suas abordagens filosóficas para serem capazes de trabalharem juntos em um texto. Houve bastante conversa, mas não estávamos chegando a lugar nenhum. Então, depois de outra xícara de chá, Chang sugeriu que eu pusesse meus deveres de lado por seis meses e estudasse filosofia chinesa, para que depois eu pudesse ser capaz de preparar um texto para o Comitê. Essa era a maneira dele de dizer que as influências ocidentais poderiam ser muito grandes, e ele estava olhando para Malik enquanto falava. Chang já tinha, na $\mathrm{CDH}$, tentado recomendar a importância de uma perspectiva histórica.

Algumas das delegações que tinham apoiado a decisão de delegar o rascunho para o comitê executivo tinham mudado de ideia. $\mathrm{O}$ delegado soviético começou a revolta, ao se opor à redação da carta feita pelo que ele chamou de "pequeno grupo de especialistas" (AC.1/2/p.2). Juntaram-se ao delegado soviético os delegados do Canadá, do Chile, da Tcheco-eslováquia e da França. Como decorrência dessa insatisfação, o ECOSOC estava pronto para votar em uma proposta que aumentasse o grupo de rascunho de três para oito membros, vindos da Austrália, Chile, China, França, Líbano, URSS, Reino Unido e dos Estados Unidos. Antecipando essa mudança, Eleanor Roosevelt, como presidenta, rapidamente escreveu ao ECOSOC uma carta em que ela dizia que a CDH faria o que fosse demandada fazer. O ECOSOC estava satisfeito e sua resolução "Requisitava que o Secretariado preparasse uma breve e curta descrição com respeito a uma Carta Internacional de Direitos Humanos". O aumento do Comitê Redator, de três executivos para oito representantes, fez o processo de redação ser mais inclusivo e aumentou a universalidade da Declaração.

Depois que o ECOSOC se reuniu e demandou um breve rascunho, Humphrey foi para Nova Iorque, por uma semana, para terminar seu rascunho e preparar os papéis de trabalho para o Comitê Redator que se reuniria em junho de 1947. Esses papéis revelam a extensão das bases do primeiro rascunho de Humphrey em materiais existentes e nas instruções que ele recebeu da Primeira Sessão da Comissão e do Conselho Econômico e Social. Ele tinha uma coleção de rascunhos, dos quais ele fez uso livre. Essa 
busca pelos melhores artigos dos vários rascunhos contribuiu para um primeiro rascunho inclusivo e explica, entre outras coisas, porque há direitos econômicos, sociais e culturais na Declaração Universal. (gn)

Que essa busca pelos artigos em materiais existentes dita o ritmo para o resto dos procedimentos, evidencia-se pelo sentimento que Geoffrey Wilson, delegado britânico, compartilhou com Humphrey, quando cruzavam o oceano Atlântico juntos. Wilson confidenciou com Humphrey que "uma vez que o Secretariado tinha incluído algo em seu rascunho, era muito difícil para os governos se oporem a inclusão de artigos", um comentário que Humphrey observou dizer respeito aos direitos econômicos e sociais, que o Reino Unido não tinha incluído na proposta que ele tinha submetido; porém se aplica a toda a Declaração. Por todas as etapas de elaboração, o ônus da prova caia naquelas delegações que queriam suprimir certa provisão. Com relação ao conteúdo, desde o começo, as escalas foram direcionadas para a universalidade. (gn)

Humphrey conta-nos da onde retirou algumas proposições normativas:

"o melhor texto que eu trabalhei foi um preparado pelo Instituto de Direito Americano [que a delegação panamenha introduziu em São Francisco], e eu emprestei dele livremente".

Morsink confirma que Humphrey, de fato, tomou emprestado frases inteiras desse rascunho para seus próprios artigos 2,3,6,7,11,15,20,22,26,30,36,41 e 42, os dois últimos dizem respeito ao direito à "segurança social". Outra proposição normativa que o influenciou enormemente foi uma submetida pelo Comitê Jurídico Interamericano. Dessa proposição, ele tomou emprestado para seus artigos 3,5,17,28,32,33,35 e 37, os últimos quatro lidam com direitos à nacionalidade, ao asilo, aos cuidados médicos e ao trabalho socialmente útil.

Humphrey alega que nenhuma das proposições normativas que ele tinha em mãos continha o direito à personalidade legal e que esse direito foi sua "invenção". Ademais, seu artigo 46, que lida com os direitos das pessoas pertencentes às "minorias étnicas, linguísticas ou religiosas, foi inteiramente emprestado do rascunho que Hersch Lauterpacht tinha publicado em 1945". 
Devemos concluir, afirma Morsink, que essa proposição normativa elaborada por Humphrey tanto é a primeira quanto o rascunho básico para posteriores supressões e adições. Esse documento, numerado E/CN.4/AC.1/3 de 4 de junho de 1947, é a primeira proposição normativa da Declaração Universal. (gn)

\section{$\underline{\text { ETAPA } 2}$}

Em 8 de abril de 1947, Eleanor Roosevelt nomeou o Comitê Redator expandido para oito nações. As reuniões de junho da Primeira Sessão desse Comitê Redator constitui a etapa 2 do processo de elaboração. Havia bastante tempo para que os resultados fossem passados para a Segunda Sessão da Comissão de Direitos Humanos, o que estava marcado para se reunir em dezembro em Geneva. Os delegados foram apresentados com as 4 seguintes proposições normativas :

1. Um Esboço Preliminar de Projeto da Carta Internacional de Direitos Humanos, também conhecido como o Avant-Projet de la Déclaration Internationale des Droits de 1’Homme (E/CN.4/AC.1/3/June 4,1947). Esse documento é o primeiro rascunho da Declaração Universal, discutido acima. A palavra "rascunho" no título simplesmente significa que é o rascunho que o Humphrey preparou, as várias versões dele estão na biblioteca da McGill University. Ele é também chamado de "breve", porque o Conselho Econômico e Social tinha redigido seu pedido para Humphrey nos termos de um "Esboço Documentado" da carta. Tendo feito todo o trabalho, Humphrey não podia, simplesmente, engavetar seu projeto, nem ele poderia chamá-lo de rascunho, uma vez que não era o que o seu novo mandato demandava. Então, ele chamou sua proposição normativa de "esboço descritivo". Ele admite que ele "poderia ter interpretado o pedido do ECOSOC como uma lista de direitos meramente".

Eu escolhi não interpretá-lo desse modo, diz Humphey, e preparei um rascunho de declaração que, entretanto, era reconhecido como o "Esboço Preliminar do Secretariado".

Esse foi a primeira proposição normativa oficial da Declaração

\section{Universal.}


2. Esboço Documentado (ECN.4AC.13 Add.2 de 9 de junho de 1947).

Esse documento foi apresentado um pouco mais tarde. A primeira parte desse documento continha observações feitas pelos delegados presentes à Primeira Sessão da Comissão de Direitos Humanos. Declarações e propostas submetidas por vários países e organizações não governamentais. Esse documento tem mais de 400 páginas, porque, na parte 2, Humphrey juntou para examinar e comparar cada artigo de sua própria proposição "Esboço Preliminar do Secretariado" com as provisões constitucionais dos Estados membros. Por exemplo, o direito a um julgamento justo, que estava positivado na maioria das constituições mundiais, estava presente no artigo 6 da proposição normativa do Humphrey. Ele e sua equipe fizeram o mesmo para cada um dos seus 48 artigos. O fato de quase todos os artigos na Declaração terem uma correspondência equivalente com as constituições existentes adiciona grande autoridade e universalidade ao documento. (gn)

3. Plano de Rascunho de uma Carta Internacional de Direito/ Plan de l'Avant-Projet de la Déclaration Internationale de Droits de l'Homme (E/CN.4/AC.1/3/Add.1 de 2 de junho de 1947). No caso de o Conselho Econômico e Social ter requerido de Humphrey somente um rascunho com uma lista temática para possíveis direitos, esse documento satisfaria a demanda. Nesta proposição normativa, Humphrey simplesmente lista os direitos - não em sentenças - de seu rascunho e mostra-nos a estrutura e os "capítulos" por trás da lista. Esse plano mostra que os 48 artigos do rascunho de Humphrey foram selecionados de acordo com uma lógica bem pensada. Nele, Humphrey expôs para os delegados as 5 regras que ele tinha seguido na redação de seu rascunho : (1) as constituições dos Estados membros foram consideradas; (2) a carta deve ser aceitável para todos os membros das Nações Unidas; (3) a carta deve ser curta, simples, fácil de entender e expressiva; (4) ela deve ser uma reafirmação dos direitos mais elementares; (5) ela deve cobrir as classificações básicas dos direitos. (gn)

Humphrey alegou que sua proposta normativa satisfazia todos esses critérios e que ele tinha baseado suas diretrizes nos comentários feitor pelos delegados presentes à Primeira Sessão da $\mathrm{CDH}$ (AC.1/7) 
4. A Proposta do Reino Unido. O quarto documento crucial que todos os delegados do Comitê de Redação receberam foi a proposta britânica para uma carta de direitos internacionais (E/CN.4/AC.1/4). A diferença entre este documento e o rascunho de Humphrey era que o britânico foi redigido mais na forma de uma convenção legalmente vinculante, enquanto o de Humphrey era mais uma declaração de princípios.

Com tudo isso e mais materiais em sua mesa, o Comitê Elaborador dos Oito não teve de começar do zero. Imediatamente, muitas perguntas foram levantadas sobre a proposta de Humphrey com 48 artigos. Na segunda reunião, René Cassin da França apoiou a proposta do Secretariado "como uma base sólida e interessante para o trabalho do Comitê de Redação. Cassin sugeriu que essa proposta normativa pudesse servir de base para a discussão da perspectiva material" (SR.2/p.2). Depois que os delegados ponderaram as forças e as fraquezas das propostas do Reino Unido e de Humphrey, eles decidiram "escolher a proposta do Secretariado como base para discussão". Eleanor Roosevelt preferiu a proposta do Secretariado, porque ela "considerou muitos outros documentos formatados como carta e que tinham sido submetidos à $\mathrm{CDH}$. Se necessário, disse Roosevelt, o Comitê Redator deveria errar no lado de incluir muito".(gn)

Afirma Morsink que as árduas preparações de Humphrey surtiram efeitos e sua proposta normativa fez a balança da Declaração oscilar para a universalidade em termos tanto de procedimento quanto de escopo.

Vladimir Koretsky, o delegado da URSS, abriu o sexto encontro do Comitê Redator com a proposta de constituir "um pequeno grupo de três, mais a presidenta"(SR.6/p.2). Apesar das objeções de Geoffrey Wilson do Reino Unido - que sentia que a proposta normativa de seu país não seria eleita como base para as discussões a ideia foi aceita. Um "Grupo de Trabalho Temporário, consistindo de representantes da França, do Líbano e do Reino Unido" foi nomeado. Esse pequeno grupo convidou Cassin para encontrar "um arranjo lógico dos artigos do rascunho fornecido pelo Secretariado" e "para reescrever vários artigos à luz das discussões do Comitê Redator". Cassin, delegado francês, submeteu dois documentos (os quais logo foram combinados em um) como representantes desse GT Temporário. O primeiro dos dois era a reescrita dos artigos 7 até o 48. Na margem de sua reescrita, Cassin lista próximo a cada um de "seus" artigos, os artigos de Humphrey que foram copiados ou reescritos.(gn) 
Morsink afirma que:

Ao comparar os textos de Humphrey e de Cassin, eu encontrei , somente, três artigos completamente novos: 28,30 e 44. Cassin pegou todos os outros ou de forma completa ou em parte do, então chamado, esboço do Humphrey. Cassin evidentemente exagerou na sua função, quando, em 1958, em uma palestra, ele explicou que ele tinha sido "encarregado por seus colegas a redigir, sob sua única responsabilidade, o primeiro rascunho da Declaração". Humphrey estava certo, quando ele publicou em suas memórias algo que ele sabia desde sempre, que "o novo texto do Cassin reproduzia meu próprio em sua essência e estilo". Uma vez que muito da reescrita de Cassin veio, diretamente, do rascunho original de Humphrey, não faz sentido dizer que Cassin fez um rascunho da Declaração independente.

No final do décimo encontro, o Comitê Elaborador convidou Cassin "para preparar...uma minuta revisada de suas propostas para os artigos que poderão ser incluídos na Declaração" (SR.10/p.13). No décimo segundo encontro, essa segunda revisão de Cassin (W.2/Rev.2), que não tinha as anotações na margem ao texto de Humphrey, tornou-se a base da discussão. Essa segunda revisão, "submetida pelo representante francês", foi discutida no restante dos encontros e é o documento usado na recomendação final do Comitê Redator para a Segunda Sessão da CDH.(gn)

Esclarece Morsink que

desse ponto em diante - ou seja, do final da Primeira Sessão do Comitê Redator - todas as revisões,supressões e adições, nunca mais foram associados com um pessoa ou um país. Enquanto inúmeros documentos foram introduzidos ou mencionados, o documento básico para a discussão foi sempre aquele que tinha sido aprovado pela etapa redatora ou órgão predecentes. 


\section{$\underline{\text { Etapa } 3}$}

A terceira etapa da redação consiste da Segunda Sessão da Comissão completa de dezembro de 1947. Apesar dessa Comissão com 18 membros ser maior do que o Comitê redator subsidiário com 8 membros, a Comissão buscou alargar seus insumos de várias formas. Em todas as suas sessões, assim como aquelas do Comitê Redator, várias organizações não governamentais estiveram presentes. Compareceram a essa Segunda Sessão da Comissão, por exemplo, consultores das seguintes organizações : Federação Americana do Trabalho, Federação Internacional de Sindicatos Cristãos, União Católica das Ligas das Mulheres, Quadro de Coordenação das Organizações Judaicas, Federação Abolicionista Internacional, Comitê Internacional da Cruz Vermelha, Conselho Internacional de Mulheres, Congresso Mundial Judaico (E/600). Algumas dessas organizações submeteram suas próprias propostas normativas à Comissão de Direitos Humanos.

As opiniões de grupos que não tinham status consultivo eram passadas para a $\mathrm{CDH}$ por meio do Secretariado na forma de resumos. Dessa forma, o Comitê Permanente de Espiritualistas da Argentina requisitou que "a pena capital fosse tornada ilegal nos países onde ela ainda existia, pois qualquer forma de morte violenta é não Cristã". Mesmo os requerimentos de cidadãos individuais foram registrados e passados adiante. Um residente de Hartford, Connecticut, exortou a Comissão a não esquecer as sérias situações das pessoas "vivendo sem um status de nacionalidade".

Segundo Morsink,

todas as indicações são de que a maioria desses insumos não governamentais mais ou menos informais foram apreciados e com frequência usados.

Na abertura da Terceira Sessão da Comissão, no dia 24 de maio de 1948, Roosevelt "leu um telegrama que ela tinha recebido do presidente da conferência de uma centena de organizações internacionais não governamentais que estava sediada em Geneva, desejando à CDH êxito em seus trabalhos" (SR.42/p.3). 
Essa Segunda Sessão da Comissão, que se reuniu em Geneva, produziu o que ficou conhecido como "o Rascunho de Geneva". Essa Segunda Sessão se dividiu em 3 grupos de trabalho em razão dos propósitos redacionais. No grupo de trabalho sobre a Declaração, estavam representadas as delegações dos Estados Unidos, da França, da Bielorussia, do Panamá, das Filipinas e da URSS. Nesse grupo de trabalho, as relações entre os antagonistas da Guerra Fria foram as melhores que podiam ser, o que significou que muito trabalho foi feito. (gn)

Uma vez que apenas 18 nações estavam representadas na Comissão de Direitos Humanos e que somente 8 , no Comitê Redator subsidiário à $\mathrm{CDH}$, um modo teve de ser encontrado para que os outros 38 membros das Nações Unidas contribuíssem com a formatação da carta. A esses outros, foram dadas, no mínimo, quatro oportunidades. A primeira oportunidade foi quando Humphrey e sua equipe compararam cada artigo da proposta do Secretariado com as provisões constitucionais dos Estados membros.

Também, em qualquer momento durante os procedimentos, um país era livre para submeter sua própria proposta normativa. Os seguintes países assim o fizeram, e, em mais de um caso, tiveram suas sugestões debatidas, com vigor, e incorporadas na carta final: China, Reino Unido, Fança, Chile, Equador, Cuba, Panamá, Índia e Estados Unidos. No debate final da Assembleia Geral, Malik, o representante do Líbano, fez referência a todos esses insumos com a observação de que:

A presente declaração tinha sido redigida em base internacional firme, pois a minuta do Secretariado foi uma compilação não apenas de centenas de propostas feitas por governos e indivíduos, mas também das leis e das descobertas jurídicas de todos os Estados membros da ONU" (GA,p.858).

A segunda oportunidade que os outros 38 países tiveram uma chance de tornar seu desejo explícito foi quando eles foram convidados a comentarem a proposta normativa de Genebra, que tinha sido redigida pela Segunda Sessão da CDH. Os 14 governos seguintes responderam: Egito, Noruega, África do Sul, Paquistão, Canadá, Holanda, Austrália, Estados Unidos, Nova Zelândia, Índia, Suécia, Brasil, França e México (E/CN.4/82). 
Segundo Morsink,

a Comissão de Direitos Humanos, de fato, levou em consideração essas respostas. Por exemplo, a primeira sentença do artigo 12 é baseada na versão proposta pela delegação chinesa e foi aceita no lugar da versão proposta pelo Comitê Redator.

\section{$\underline{\text { Etapa } 4}$}

A etapa 4 de elaboração ocorreu em maio de 1948, quando o Comitê Redator de 8 membros da Segunda Sessão da Comissão se reuniu. Muito dessa etapa foi gasta discutindo um pacto, porque, naquele tempo, muitos delegados ainda continuavam a demandar a adoção de ambas, uma declaração e um pacto como parte da carta internacional de direitos. Essa escolha entre apenas uma declaração ou ambas (uma declaração e uma convenção) criou uma enorme tensão dentro da CDH e em seu Comitê Redator subsidiário, e tomou uma quantidade enorme do precioso tempo de elaboração. (gn)

\section{$\underline{\text { Etapa } 5}$}

A quinta etapa da redação da Declaração compreende os encontros da Terceira Sessão da CDH. Eles começaram logo após as reuniões de maio do Comitê Redator terem terminados, e seguiram até a metade de junho de 1948. As discussões nesta quinta etapa foram muito intensas, porque a $\mathrm{CDH}$ estava num clima de cortar o que muitas delegações consideraram ser uma proposta normativa demasiado complexa que tinha saído da Segunda Sessão da CDH em Genebra. O maior desafio veio de uma séries de propostas conjuntas do Reino Unido com a Índia que reduzia quase todos os artigos a um mínimo. Foi somente neste momento bem avançado que a Comissão decidiu que ela só poderia fazer a Declaração ser analisada pela Terceira Assembleia Geral das Nações Unidas. Tanto o pacto quanto suas medidas de implementação foram postergados. (gn) 


\section{$\underline{\text { ETAPA } 6}$}

As reuniões do Terceiro Comitê (Social e Humanitário) da Assembleia Geral, que ocorreram de setembro até dezembro de 1948, formam a sexta etapa da redação. Além da pesquisa de Humphrey acerca das constituições e das contribuições dos governos, como resposta do Rascunho de Genebra, os encontros do Terceiro Comitê proporcionaram uma terceira oportunidade para as nações que não tinham representação na Comissão de Direitos Humanos de 18 membros para fazerem seus comentários. Mesmo que as Segunda e Terceira Sessões tivessem aprovado a Declaração com expressivas votações, o Terceiro Comitê da AGNU examinou todo o documento. Depois a $\mathrm{CDH}$ e sua subsidiária na redação já terem devotado 5 sessões morosas em um período de quase dois anos para a redação do documento, os delegados do Terceiro Comitê tiveram mais 85 encontros, sem contar os 20 encontros de vários subcomitês.

Malik, o delegado do Líbano que tinha sido o presidente do Terceiro Comitê, relatou à AGNU a respeito do amplo apoio que o documento tinha recebido em seu comitê. "Dos 1.233 votos individuais realizados", disse Malik, "88.08 \% tinham sido afirmativos e $3.73 \%$ negativos. 18 artigos foram adotados "sem qualquer oposição"(GA, p860). O Terceiro Comitê adotou a declaração com uma votação de 29 favoráveis, nenhum contra e 7 abstenções (GA, p.860).

No começo dos procedimentos desse Terceiro Comitê, Cassin, delegado francês, tinha expressado a esperança de que

"a declaração de direitos humanos poderia ser a expressão dos direitos de todos os povos do mundo, e não apenas das 58 nações constituintes das Nações Unidas".

Os comentários feitos na última etapa de elaboração mostram que muitos de seus colegas viam o trabalho deles dessa forma. (gn) 


\section{$\underline{\text { ETAPA } 7}$}

A sétima etapa de elaboração foi o debate na Sessão Plenária da Terceira Assembleia Geral, que levou à adoção da Declaração naquele mesmo dia 10 de dezembro de 1948. Essa era a quarta vez que o resto dos membros da ONU poderia emendar o que a Comissão dos 18 tinha feito. Tanto a Assembleia Geral quanto o Terceiro Comitê se reuniram em Paris naquele ano. Enquanto várias emendas foram propostas, somente uma mudança substantiva foi feita.

Quase metade do tempo foi gasto para explicar abstenções e outra metade foi dedicada com discursos de felicitações com respeito àquilo que os delegados tinham realizado. Naturalmente, eles estavam orgulhosos da marca inclusiva do processo de elaboração. Os delegados estavam tentados a moverem-se da inclusão processual para a alegação de que o produto tinha aplicabilidade mundial.

F.Corbet, um representante do Reino Unido, observou que:

a declaração era um documento internacional que representava o denominador comum de um acordo entre a maioria das nações do mundo (GA, p.884).

Jorge Carrera Andrade, o representante do Equador, observou que:

no decorrer de muitos séculos de lutas políticas para promover a unidade humana, o clímax tinha sido alcançado com a preparação do documento em que 58 nações tinham expressado seus ideais comuns e sua identidade de pensamentos com relação aos direitos humanos fundamentais (GA, p.918).

O presidente da Terceira Assembleia Geral, Herbert Watt, representante da Austrália, observou que :

era a primeira ocasião em que a comunidade de nações organizadas tinha feito uma declaração de direitos humanos e de liberdades fundamentais. Esse documento foi apoiado por todo corpo 
consultivo da ONU e milhões de pessoas, homens, mulheres e crianças de todo o mundo, procurariam a Declaração como fonte de ajuda, de orientação e de inspiração.(GA, p.934).

Watt não era o único que pensou que, de alguma forma, toda a humanidade tinha sido representada no processo de redação que vinha a terminar. Abdul Rahman Kayala, o representante da Síria, também notou que:

a civilização tinha progredido lentamente durante os séculos de persecução e de tirania, até finalmente a presente declaração ter sido redigida. A declaração não era o trabalho de poucos representantes na AGNU ou no ECOSOC; ela era a realização de gerações de seres humanos que tinham trabalhado com vistas aquele fim. Agora, pelo menos os povos do mundo ouviriam que a proclamação da declaração tinha atingido sua meta e tinha sido realizada pelas Nações Unidas" (GA, p.922).

Essa Terceira Assembleia Geral adotou a Declaração perto da meia noite do dia 10 de dezembro de 1948 com uma votação de 48 favoráveis a nenhum contra e com 8 abstenções. 


\section{8 - A PARTICIPAÇÃO DO PODER NO COMPLEXO FACTUAL- -AXIOLÓGICO DA NOMOGÊNESE DO DIREITO À ALIMENTAÇÃO}

No tempo em que a Declaração Universal estava sendo escrita (19471948), o consenso internacional sobre direitos humanos era agressivo. Depois de repetidas condenações pelos Aliados das violações nazistas de direitos humanos, muitos países começaram a encarar a ONU como a nova organização mundial que teria de ter poder coercitivo. Esses países não queriam uma organização que fosse tão impotente quanto a Liga das Nações tinha sido na década de 1930, quando ela falhou em prevenir a conquista da Etiópia pela Itália e a possessão da Renânia por Hitler. Assim, o forte desejo de querer que as conversações de direitos humanos não fossem apenas conversas, mas secundados com a necessária maquinaria de implementação e de realização foi a tônica do período.

Foi nessa atmosfera internacional que o Conselho Econômico e Social escreveu, em fevereiro de 1946, os termos de referência que guiariam a Comissão de Direitos Humanos em seus trabalhos. Esses termos de referência tornaram-se objeto de intensos debates e controvérsias, que, por isso, será citado textualmente:

O ECOSOC manda que :

o trabalho da Comissão seja direcionada a submissão de propostas, de recomendações e de relatórios ao Conselho com relação :

(a) uma carta internacional de direitos;

(b) declarações internacionais ou convenções sobre as liberdades civis, o status das mulheres, liberdade de informações e matérias similares;

(c) a proteção de minorias;

(d) a prevenção de discriminação em razão da raça, do sexo, da língua ou da religião;

(e) qualquer outra matéria concernente aos direitos humanos que não foram cobertas pelos itens acima (E/248). 
Explica-nos Morsink ${ }^{67}$ que a diferença entre (a) e (b) é que, em (a), o ECOSOC estava pensando em uma carta internacional genérica de direitos, enquanto em (b) o Conselho tinha em mente "declarações internacionais e convenções" mais específicas sobre vários tópicos. Essas declarações mais específicas ou convenções estão relacionadas com algumas subcomissões que sugeriram a criação da Comissão de Direitos Humanos.

Durante todo os primeiros dois terços do período de redação e bem avançando na Terceira Sessão da Comissão que se reuniu em maio e junho de 1948, a Comissão estava envolvida em uma luta sobre os termos de referência. A maioria das delegações sentia que a frase "carta internacional de direitos" significava não menos que uma convenção, enquanto as duas superpotências, os Estados Unidos (quase todo o tempo) e a União Soviética (todo o tempo) insistiam que o Conselho quis dizer que a Comissão tinha de redigir uma declaração ou um manifesto de princípios sem quaisquer maquinarias de implementação anexas nelas. Essa batalha durou muito tempo e consumiu uma enorme quantidade de energia dos redatores. (gn)

No primeiro encontro da Primeira Sessão da Comissão Plena, tarde em janeiro de 1947, Humphrey distribuiu o que ele denominou de "os termos de referência consolidados da Comissão", o que incluiu o pedido de conselho de fevereiro de 1946 sobre "uma carta internacional de direitos". Humphrey disse à Comissão que havia três modos de a CDH realizar o pedido do ECOSOC para uma carta internacional de direitos: "uma declaração ou outro ato da Assembleia Geral, um pacto multilateral ou uma emenda a Carta da ONU".

Morsink comenta que "dessas três, somente as duas últimas - o pacto ou a emenda à Carta da ONU - teriam sido responsivas à intenção original de que os direitos proclamados também fossem implementados. Os artigos 108 e 109 da Carta da ONU especificam um procedimento bem complexo para a realização de emendas à Carta e esse modo de tornar uma carta internacional de direitos efetiva nunca foi seriamente considerado, o que nos deixa com a declaração ou o pacto ou ambas.

${ }^{67}$ MORSINK, Johannes, The Universal Declaration of Human Rights : Origins, Drafting and Intent, University of Pennsylvania Press, 1999. p.13 e sgts. 
Um pacto é muito mais difícil de ser redigido, porque ele é muito mais detalhado do que uma declaração geral de princípios. O pacto precisa ser feito por especialistas em direito internacional e leva muito tempo para ser escrito. Além disso, os Estados que assinam a convenção ou o pacto se comprometem a dizer "às autoridades" como eles têm implementado os termos da convenção em seus próprios sistemas jurídicos domésticos. Essas promessas com frequência tomam a forma de outras promessas de escrever relatórios sobre o progresso sendo feito na adaptação do sistema jurídico doméstico aos novos padrões internacionais recentemente aceitos. No caso de desacordos sobre se um Estado manteve ou não suas promessas, um Estado envolvido nessas disputas, com frequência, promete concordar com procedimentos voluntários de arbitragem. Finalmente, a única força envolvida é a sanção do isolamento internacional.(gn)

Uma declaração, por sua vez, em comparação é bem mais simples. As partes necessitam concordar com os princípios a serem proclamados e, então, proclamamnos. Mesmo que seja verdade que os diplomatas que escreveram a DUDH1948 eram representantes oficiais de seus respectivos governos, que os diziam como votar e o que submeter, o fato em si não transforma a declaração em um convenção detalhada e obrigatória. A verdade é que as nações podem descumprir a declaração muito mais facilmente do que uma convenção ratificada. Essa é a razão precisa pela qual a maioria dos Estados-nação pequenos queria uma convenção que vinculasse tanto as nações pequenas quanto as grandes, e não uma mera declaração. O desejo dessas nações menores foi frustrado, porque em fases importantes do debate ou os Estados Unidos ou a União Soviética ou ambos retardavam ou bloqueavam o progresso da redação de uma convenção. Os oponentes mais insistentes de uma mera declaração eram os delegados do Reino Unido e da Austrália. (gn)

Depois da Segunda Sessão da Comissão, as propostas normativas da declaração e da convenção foram enviados para os governos membros comentarem. Provavelmente como resultado desses comentários e, em razão dos lobbies por trás das cenas, a Segunda Sessão do Comitê de Redação devotou todo o seu tempo à convenção. 
Toni Sender da Federação Americana Trabalhista

pensou que era encorajador que muitos governos terem comentado favoravelmente sobre o tema da implementação.

Os Estados Unidos também tinham se decidido novamente a apoiar o rascunho do pacto mais ativamente. Eleanor Roosevelt pensou que, talvez, fosse possível passar na Terceira Assembleia Geral ambos o pacto e a declaração. Isso criou um momento ímpar para a redação e a melhoria do pacto, e o Comitê Redator decidiu em uma votação apertada de 3 favoráveis a 2, com 2 abstenções, gastar mais tempo na redação do pacto. Duas vezes, o Comitê debruçou-se sobre os artigos do pacto que tinha se originado da proposta normativa britânica, e não gastou nada de seu tempo na redação da declaração. Parecia, afinal, que o pacto se tornaria o equivalente da Declaração.

A única oposição à convenção vinha da União Soviética, e mesmo assim não era tão contundente. Alexie Pavlov começou com um discurso afiado em relação à Guerra Fria, mas sua atitude durante o restante da Segunda Sessão foi muito conciliatória. Apesar de ser a posição oficial da União Soviética de que "a redação de um Pacto ser prematuro", Pavlov fez várias sugestões positivas além das usuais. Essa atitude de cooperação coincidiu com o levantamento temporário do bloqueio de Berlim ${ }^{68}$, mas

${ }^{68}$ José Sombra Saraiva, no capítulo 6. Dois Gigantes e um condomínio: da guerra fria à coexistência pacífica (1947-1968), seção 6.1.3, Da Alemanha à Coréia: o mundo na balança da guerra fria, contextualiza esse fato histórico: Um sucessão de crises embalou as relações internacionais da Guerra Fria entre 1947 e 1955. Iniciada por Berlim e estendida pela Guerra da Coréia, a efervescência das disputas interimperiais norteamericanas e soviéticas se fez presente em várias partes do mundo. Os dois gigantes disputavam, quase sempre, novos espaços no condomínio internacional.

O bloqueio de Berlim, resultante da reação soviética à política de contenção norte-americana, tornou o ano de 1948, para os europeus recém-saídos de uma guerra mundial, um pesadelo. A crise no ponto mais vulnerável do carrefour Ocidente-Oriente elevou a tensão entre as superpotências a altos níveis de temperatura política.

Localizada a mais de 150 quilômetros dentro da zona de ocupação soviética e dividida internamente, dentro da lógica de Potsdam, em quatro áreas de ocupação, Berlim foi bloqueada por Stalin como teste do grau de determinação dos seus adversários e como reação à doutrina Truman. Em Berlim, confrontavam-se os dois mundos: na Berlim Ocidental, os EUA haviam despejado os dólares de ajuda econômica, enquanto, na Berlim Oriental, os soviéticos extraíam riquezas para o plano de reconstrução da URSS.

Cortando o tráfego ferroviário e rodoviário do Ocidente, Stalin desafiou Truman, ocupado em sua campanha de reeleição e pego de surpresa pelos fatos. Durante os meses em que o mundo assistiu aos preparativos para uma nova guerra mundial, foram testadas várias modalidades de negociação. $\mathrm{O}$ argumento de Stalin era o de que Berlim não poderia ser um enclave ocidental no interior de uma zona de ocupação soviética, ali plantado para desestabilizar a construção do socialismo. O pretexto para seus movimentos havia sido a reforma do marco na Alemanha Ocidental e seus efeitos para Berlim, que teria duas moedas, uma delas absolutamente incorporada ao Ocidente. 
provou-se ser o último degelo.

O fim da resistência ocorreu na Terceira Sessão da Comissão. Falando como presidenta da $\mathrm{CDH}$, Roosevelt sugeriu que fosse gasto uma semana cada na preparação da Declaração, do Pacto e das medidas de implementação. Disse ela que esse cronograma satisfaria o mandato do Conselho Econômico e Social (SR.46/p.4).

Cassin, representante francês, queria discutir a Declaração primeiro, e Pavlov, representante soviético, queria começar com uma discussão de princípios gerais. Depois de Cassin ter argumentado que "a Declaração era o primeiro documento em que um acordo poderia ser alcançado", uma proposta francesa que desconectou a Declaração de qualquer medida de implementação, incluindo uma convenção, foi adotada por nove votos a dois. (gn)

\section{O fim da resistência significou que a delegação do Reino Unido} apoiou a proposta francesa e, ao assim fazer, desistiu de sua posição de tudo ou nada. As minutas afirmam que "o sr. Wilson do Reino Unido apoiou a proposta do representante francês. A Comissão tinha sempre examinado os dois documentos separadamente e a mudança de método na Terceira Sessão poderia levar à confusão. Além disso, os objetivos

Stalin levou adiante seu plano com determinação, desprezou as ameaças de Truman e preparou-se para enfrentar toda a resistência, doméstica e internacional. Entendia que o tempo o beneficiaria, pois o esgotamento natural da parte ocidental da cidade tornaria o bloqueio um fato sem retorno. Para os EUA restariam saídas honrosas, como a retirada das tropas de Berlim, que implicariam a perda da confiança na própria doutrina Truman e no Plano Marshall, ou a negociação de uma solução diplomática lenta e desgastante.

Quando parecia inevitável o bloqueio, norte-americanos e britânicos iniciaram, em 28 de junho de 1948, o transporte aéreo maciço de alimentos, de combustíveis e de materiais necessários à resistência de Berlim Ocidental. Para provocar o efeito do terror e da memória da guerra, os norte--americanos mandaram, para bases inglesas, 60 bombardeiros b-29 capazes, segundo dizia, de lançar bombas atômicas.

A ameaça atômica, embora tenha sido só uma ameaça, teve forte ressonância internacional. A propaganda messiânica nos EUA e na Europa Ocidental acerca do terror comunista prestou-se a objetivos internos de poder e a situações eleitorais em quase todos os países. A desmoralização do bloqueio, especialmente pela exploração dos "corredores aéreos" legais entre a Alemanha Ocidental e Berlim, desviou o debate da opinião pública sobre os gastos gigantescos que foram empreendidos por norte-americanos e britânicos naqueles meses do segundo semestre de 1948.

O conflito foi dissipado lentamente. Stalin, que não perturbou os vôos, de norte-americanos e britânicos, rejeitou qualquer tentativa diplomática de negociação e levou em conta o diferendo nuclear entre os dois países. Berlim correspondeu, portanto, ao petardo soviético contra a triunfante guerra fria norteamericana, a evidenciar que os dois lados falavam a mesma linguagem. Em 1949, o bloqueio estava encerrado e um acordo discreto viria a ser assinado nas Nações Unidas para reestabelecer a normalidade. in SARAIVA, José Flávio Sombra. História das relações internacionais contemporâneas: da sociedade internacional do Século XIX à era da globalização, (Sombra organizador) São Paulo, Saraiva, 2008 
do Pacto e da Declaração eram diferentes e cada um desses dois documentos era uma unidade que tinha de ser examinada como um total". Esse apoio britânico foi uma mudança notável, uma vez que essa delegação vinha insistindo todo o tempo que uma mera declaração era inútil e talvez mesmo contraprodutiva, e que, dos documentos, a convenção era a parte fundamental da carta internacional de direitos. (gn)

Em um ensaio posterior, Cassin leva o crédito pela suavização da perspectiva britânica sobre a inutilidade de uma mera declaração. Ele observa corretamente que, se os delegados tivessem insistido na feitura de um pacto, eles teriam corrido o risco de deixar um período político favorável escapar. (gn)

Cassin escreve que:

A Guerra Fria já tinha começado e ameaçava comprometer a adoção tanto de uma declaração quanto de uma convenção".

Morsink explica aliviado sobre essa situação:

Felizmente, Harold Laski, um amigo de Cassin, teve a capacidade...de exercer influência favorável sobre Clement Attlee com respeito à adoção imediata de uma 'mera' declaração. Eu não verifiquei a versão do Cassin sobre o ocorrido, mas não pode haver dúvidas de que a retirada da oposição britânica foi a maior razão de a Terceira Sessão da Comissão de Direitos Humanos ter sido capaz de concentrar toda a sua atenção na elaboração da Declaração. Esse acontecimento foi, provavelmente, essencial para a adoção da Declaração em 1948. (gn)

Nos encaminhamentos finais da Terceira Sessão, Roosevelt, mais uma vez, - quase triste por querer algo que não se poderia ter - "destacou que o Conselho Econômico e Social tinha instruído a Comissão de Direitos Humanos a entregá-lo, pronto, uma proposta de Declaração Internacional, uma proposta de Convenção e provisões para a implementação de ambas, e perguntou aos membros da Comissão se eles achavam ser possível cumprir essa tarefa que lhes havia sido imposta pelo Conselho na sessão presente 
(SR.48/p.3). A CDH respondeu que sim, mas Eleanor Roosevelt sabia que não seria possível, por causa do impacto da proposta normativa francesa, que colocou a Declaração por primeiro.

De fato, naquela mesma Sessão, Roosevelt citou Abraham Lincoln para fazer dizer que havia uma diferença crucial entre ter um direito e a implementação desse direito. Lincoln havia dito que os autores da Declaração de Independência Americana

não queriam afirmar a óbvia inverdade de que todos os homens estavam realmente gozando da igualdade nem que eles iam concedê-la imediatamente para todos. De fato, os autores da Declaração não tinham poder de conferir esse benefício. Eles simplesmente quiseram declarar o direito para que a implementação dele pudesse ocorrer tão logo as circunstâncias pudessem permitir. (gn)

Morsink conclui que, se o presidente Lincoln pôde dividir em dois, então, a Comissão de Direitos Humanos também poderia, com ou sem mandato. Como ironia da história, o que preocupava muitas delegações - que a declaração delas não estava anexa nem acompanhada por uma convenção - provou-se ser uma característica muito benéfica do documento, uma que mais ajudou do que atrapalhou o processo de implementação. Quando a Terceira Assembleia Geral adotou a DUDH1948, ela também passou uma resolução demandando um término célere da convenção que a CDH não teve capacidade de terminar. No curso de maiores discussões, a CDH decidiu dividir a única convenção em duas. O resultado foi que, em 1966, duas convenções internacionais foram abertas para assinatura, o Pacto Internacional de Direitos Civis e Políticos e o Pacto Internacional de Direitos Econômicos, Sociais e Culturais. Esses dois pactos começaram a viger, quando ratificações suficientes foram coletadas dos Estados em 1976. Juntos , esses documentos fazem parte da Carta Internacional de Direitos Humanos, publicada pelo Escritório de Informações Públicas da ONU. (gn) 
No cerne dessa tríade está a separação de direitos morais das medidas concretas adotadas posteriormente para a implementação legal. Enquanto a Carta da ONU originou a Declaração, a Declaração, por sua vez, deu origem a esses dois Pactos e para tantos outros instrumentos regionais de implementação.

O fato de a Declaração em si não ter nenhuma medida de implementação deu-lhe, desde o início, um status moral independente no mundo das relações internacionais e do direito. Mais de 50 anos de sua adoção, a DUDH1948 é o padrão moral e a fonte de inspiração de um novo ramo do direito internacional totalmente novo. Antes da Segunda Guerra Mundial , quase não havia instrumentos internacionais que diziam respeito à realização dos direitos humanos. Desde então, o crescimento tem sido fenomenal, de tal forma que há cerca de duzentas diferentes declarações, convenções, protocolos, tratados, cartas e acordos, todos lidando com a realização dos direitos humanos no mundo. Desses instrumentos posteriores à Guerra, não menos de 65 mencionam em seus prefácios ou preâmbulos a Declaração dos Direitos Humanos como uma fonte de autoridade e de inspiração. 


\section{9 - QUESTÃO DE FUNDO DOS DIREITOS HUMANOS: A SEGUNDA GUERRA E O HOLOCAUSTO COMO EXPERIÊNCIAS JURÍDICAS PRÉ-CATEGORIAIS}

Uma das inevitáveis perguntas sobre a DUDH1948 é como tantas delegações de tantas nações e tradições culturais diferentes puderam ter chegado a um acordo sobre um código universal moral. Vimos que o processo usado para redigir a Declaração foi bastante inclusivo, mas também é verdade que, e isso deve ser reconhecido, que esse processo nomotético foi dominado pelas nações do entorno do Atlântico Norte (com seus amigos e antigas colônias) e da América Latina, e que grandes regiões do mundo, como a Ásia e a África, foram enormemente sub-representadas nas mesas de negociação. (gn)

Nesse contexto, Morsink pergunta ${ }^{69}$ :

O que faz a ideia de direitos humanos trazer pessoas de todas as diferentes origens em um círculo de acordo moral? O que reside no cerne do consenso moral sobre direitos humanos que nasceu na década de 1940 e se expandiu desde então?

No primeiro encontro da $\mathrm{CDH}$, Henri Laugier, o assistente do SecretárioGeral da ONU, responsável pelos assuntos sociais, encarregou a Comissão

com a tarefa de $[\ldots]$ continuar no campo da paz a luta que a humanidade livre tinha travado nos campos da guerra, defendendo contra ataques ofensivos os direitos e a dignidade do homem e estabelecendo [...] um poderoso reconhecimento dos direitos humanos (SR.1/p.2).

${ }^{69}$ MORSINK, Johannes, The Universal Declaration of Human Rights : Origins, Drafting and Intent, University of Pennsylvania Press, 1999. p.36 e sgts 
Na Primeira Sessão do Comitê de Redação, Geoffrey Wilson, um delegado do Reino Unido:

relembrou seus colegas da situação histórica em que o Comitê se reunia. Era um contexto em que a Alemanha e outros países inimigos, durante a guerra, tinham completamente ignorado o que a humanidade considerava como direitos humanos e liberdades fundamentais. O Comitê reuniu-se como um primeiro passo em direção a proporcionar a máxima salvaguarda possível contra aquele tipo de coisa no futuro.

Durante o debate final da Assembleia Geral em dezembro de 1948, os redatores evidenciaram de modo abundante que a Declaração, a qual eles estavam prestes a pôr em votação, tinha sido criada em decorrência da experiência jurídica pré-categorial da guerra que acabara de terminar. (gn)

Charles Malik, o representante do Líbano disse o seguinte sobre a declaração:

o documento foi inspirado em oposição às bárbaras doutrinas do nazismo e do fascismo.(gn)

Lakshimi Menon, seu colega indiano, disse à AGNU que

a Declaração foi criada da necessidade de reafirmar os direitos depois da violação deles durante a guerra.

Como Bodil Begtrup, delegado dinamarquês, todos os autores queriam "evitar os horrores de uma nova guerra". (grifos nossos)

Jorge Carrera Andrade, o delegado equatoriano, disse:

das ruínas causadas pela Segunda Guerra Mundial, o homem novamente tinha ventilado a flama imortal da civilização, da liberdade e da lei. Agora que o nazismo, o fascismo e seus brutais Estados totalitários tinham sido destruídos, as Nações 
Unidas deveriam lutar por um novo internacionalismo democrático.

O delegado belga, Conde Henry Carton de Wiarte, pensou que:

o mérito essencial da Declaração era o de realçar a alta dignidade da pessoa humana depois dos grandes choques os quais homens e mulheres tinham sido expostos durante a recente guerra.

René Cassin, o delegado francês, assinalou que:

a última guerra tomou a característica de uma cruzada para os direitos humanos, e que, de fato, a Declaração era a mais vigorosa e a necessidade mais urgente de a humanidade protestar contra a opressão.

Os redatores resumiram esses sentimentos na segunda consideração do Preâmbulo, onde eles nos dizem que uma das razões de eles terem proclamado a DUDH1948 era em razão de que o desprezo e o desrespeito pelos direitos da pessoa resultaram em atos bárbaros que ultrajaram a consciência da Humanidade, incluindo a consciência dos próprios autores da declaração. (grifos nossos)

Essa conexão factual-axiológica entre a experiência pré-categorial de guerra e a escritura da Declaração, como experiência jurídica cientificamente ordenada pela diplomacia parlamentar, levou Ernest Davies, um representante do Reino Unido, a emitir uma nota de alerta:

Não deve ser esquecido que a guerra e a sua total desconsideração pelos direitos mais fundamentais foram responsáveis pela Declaração, pois declarações precedentes que tinham sobrevivido na história muito tempo depois das guerras e das disputas que as tinham originados tinham sido esquecidas. 
Situa-nos Miguel Reale sobre o problema do homem, bem como sua abordagem tridimensional baseada no historicismo-axiológico personalista:

Que o problema do homem tenha adquirido ênfase especial nas últimas décadas, até se tornar "o problema" por excelência, é o que mais de um pensador o tem proclamado. ${ }^{70}$ Émile Bréhier chega mesmo a escrever que esse tema central dá unidade às múltiplas e dispersas especulações de nosso tempo, cada qual com um arsenal metódico próprio. Todos esses métodos, na fenomenologia, na psicologia da forma e na psicanálise, encontram, aliás, a sua unidade no estudo do homem, tomado não na evolução geral da natureza e da história, mas nas suas relações concretas e atuais, corpo e alma, juntamente como o mundo que o circunda, com outrem, com a realidade transmundana - do homem que só descobre os princípios e os valores na realização efetiva da ciência e na experiência da vida. (gn)

O "bem comum"71, por conseguinte, de que falo, é o bem da "comunidade das pessoas", na harmonia de "valores de convivência", distintos e complementares, em um processo histórico que tem como fulcro a pessoa, valor-fonte de todos os valores. Uma axiologia a-histórica, ou meta-histórica para mim não tem sentido. De certo ponto de vista, o homem é a sua história, concordo, mas não seria compreender integralmente o homem, compreendê-lo espelhado, unicamente no processo histórico-cultural, pois o homem é, também, a história por fazer-se.(gn)

\footnotetext{
${ }^{70}$ Incisiva a afirmação de Karl Jaspers : "Porém, surgiu agora no mundo uma preocupação completamente distinta sobre o futuro do homem que nunca existiu antes. É a preocupação pelo ser do homem, a possibilidade anunciada por Burckhardt e por Nietzsche, de poder o homem perder-se a si mesmo, de poder a humanidade, em parte insensivelmente, em parte em virtude de violentas catástrofes, desembocar no nivelamento e na mecanização, em uma vida sem liberdade e sem satisfação, em uma maldade sombria sem humanidade".

Pondere-se, aliás, que a tão controvertida "crise do Direito" não é senão um dos aspectos da crise fecunda que se opera na problemática do homem. REALE, Miguel. Teoria Tridimensional do Direito, situação atual, 5 ed. rev. e aum. - São Paulo: Saraiva, 1994, p.144 e sgts

${ }^{71}$ idem, p. 137 e segts.
} 
É próprio do homem, da estrutura mesma de seu ser, essa ambivalência e polaridade de "ser passado" e "ser futuro", de ser mais do que a sua própria história. E note-se que o futuro não se atualiza como pensamento, para inserir-se no homem como ato - caso em que deixaria de ser futuro -, mas revela-se em nosso ser como possibilidade, tensão, abertura para o projetar-se intencional de nossa consciência, em uma gama constitutiva de valores. Como bem diz Eduardo Nicol, "o que o homem 'é' em ato nunca é a atualidade completa de sua potência de ser. Por isso, 'tende' a atualizar as suas potencialidades de ser, da única maneira que nele é possível, ou seja, vivendo. (gn)

O homem não é "ser histórico" em razão da história vivida, mas o é mais pela carência da história futura. É preciso, em verdade, atentar ao significado pleno de minha afirmação de que o homem é o único ente que é e deve ser, no qual "ser" e "dever ser" coincidem, cujo ser é o seu dever ser.(gn)

Ora, a meditação sobre a condição humana, sobre a existência e suas circunstâncias, e sobre o ser do homem como seu dever ser abre-nos a perspectiva de um historicismo diverso, uno em virtude da unidade ontológico-axiológica que é a pessoa humana, e, ao mesmo tempo, infinito em virtude da carência e da implenitude do homem. Só mesmo reconhecendo a pessoa como fonte de valores (fonte do que deve ser, do que ainda não é, do que poderá jamais a vir a ser) é que se pode, com efeito, conceber a história na conciliação necessária de duas exigências essenciais, de unidade e de infinitude. (gn)

É nas pegadas recentes do pensamento de Roubier que se situam os estudos recentes de um antigo discípulo, Francis Lamand para quem o "tridimensionalismo tem o mérito de pôr acento sobre a integração dos valores". Ao seu ver, porém, as três dimensões - fato, valor e norma - não reconstituem a unidade do jus no tempo, que, a seu ver, representaria mais uma das 
dimensões do direito. Penso, todavia, que o tempo não constitui uma nova dimensão da estrutura do direito, mas é essencial à significação da estrutura jurídica mesma, como realidade dialética que é. (gn)

Valor e historicidade são, ao contrário, inerentes à consistência mesma da pessoa, de maneira que não tem sentido tanto um humanismo a-histórico, ou meta-histórico quanto um humanismo que se revele integral e absolutamente na história, aniquilando a condição mesma de sua possibilidade. Pois bem, se a pessoa é o valor-fonte e se ela se revela axiologicamente na história, não me parece possível dizer-se que, em minha concepção, os valores não têm hierarquia ou se dispõem "horizontalmente" sobre o mesmo plano ${ }^{72}$. [...] Não há tal. Se o valor da pessoa humana condiciona a experiência estimativa do homem, o que quer dizer a sua história, é claro que é nos ciclos culturais que se desenvolvem os esforços de realização do humano, de maneira que em torno do fulcro central vão-se ordenando constelações axiológicas distintas, múltiplas expressões do Espírito no processo de seu desvelar-se. Daí me referir a uma invariante axiológica, ou, por outras palavras, a um conjunto de valores fundamentais que, uma vez trazidos historicamente ao plano da consciência, tornam-se bens comuns, essenciais ao viver social, como se fossem inatos. (gn)

\footnotetext{
${ }^{72}$ Embora subordinado a outro prisma, ao que denomina "a dialética da participação", as ponderações de Le Senne sobre as insuficiências de uma "hierarquia linear" de valores, segundo a qual todos seriam subordinados a um deles, na medida de uma ordem progressiva de excelência, quando, na realidade, seria preferível conceber-se tal unidade como "unidade de irradiação" subordinada a um valor central.

O pluralismo axiológico que sustentamos não é, pois, horizontal, mas se irradia da pessoa como valor-fonte, constituindo, segundo a problemática histórica do homem, "constelações axiológicas diversas", que assinalam os ciclos ou formas de cultura. Não obstante o variar desses ciclos e a sua intercorrência, há algo de constante no processo histórico, governado pelo foco irradiante central, como se explica no texto.

O historicismo de tipo hegeliano, marxista e positivista, correspondente à cosmovisão do século passado, deve ceder lugar a um historicismo axiológico, múltiplo e perspectivístico, capaz de coimplicar e polarizar os contrastes inerentes ao ser do homem. O historicismo hegeliano, o marxista e o positivista não correspondem mais à consciência atual da história. (gn)
} 
Aplicando essa visão axiológica ao mundo do Direito, parece-me possível atribuir o constante renascer do Direito Natural ao sentimento de que a vida do Direito não pode deixar de obedecer a pressupostos ligados às exigências históricoaxiológicas, às conquistas da experiência humana na sua autoconsciência temporal

$$
\text { Conservando embora a expressão "Direito }
$$

Natural", não me refiro, por conseguinte, como o julgou Kunz, a um ente jurídico ontologicamente diverso do Direito positivo, a uma duplicata desnecessária do jus vivens, no qual se espelhe o nosso perene e inconformado esforço de realização de justiça. Quando falo em Direito Natural, uso tal expressão à luz de "historicismo axiológico", acima invocado, razão pela qual escrevo em Filosofia do Direito: "Não se reduz, desse modo, o Direito à simples condicionalidade lógico-transcendental, com a qual Kant exprimiu o individualismo fundamental de sua época; nem a uma condicionalidade sociológica" à maneira de Jhering, tentando um compromisso garantido pelo poder público entre interesses individuais reciprocamente compensados; porque "só pode e deve ser visto em termos de condicionalidade histórico-axiológica, visando uma ordem social justa, na qual os homens e os grupos possam se desenvolver livremente, assim como completar-se econômica e eticamente uns aos outros no sentido de uma comunidade concreta". (gn)

Surge, assim, o Direito Natural como conjunto das condições histórico-axiológicas da experiência jurídica, sem envolver a existência de duas regiões ônticas distintas. O Direito Natural é, em suma, o Direito Positivo mesmo enquanto remontado às suas fontes possibilitantes e, ao mesmo tempo, enquanto projetado na linha ideal de seu desenvolvimento, na plena implicação e polaridade do homem como "ser passado" e 
"ser futuro", que "é" e "deve ser".(gn)

Já naquele tempo, porém, ao assumir posição correspondente a uma axiologia de base "personalista", não estava volvendo a superadas concepções do passado. Correspondia antes às exigências de nossa época, uma das quais ligada ao problema central do homem e ao significado de sua existência, não do homem em abstrato, como elo de um processo objetivo ou momento de um devir universal, mas sim do homem in concreto, na plenitude social e histórica de seu ser, com todas as limitações e insuficiências, nas sua condição ambivalente de "singularidade" e de "sociabilidade", de "racionalidade" e de "a-racionalidade", de "subjetividade" e de "transcendência", na implicação das tensões valorativas que assinalam o ritmo de seu existir autêntico. (gn)

$\mathrm{Na}$ realidade, posta e reconhecida a complexidade do contraditório problema do homem, quatro são as atitudes fundamentais possíveis no que concerne às suas antinomias: ou (1) se persevera no otimismo romântico do século XIX, e notadamente de Hegel, visando-se a integrar na unidade atual do espírito todos os conflitos, graças a uma síntese dialética superadora de opostos; ou (2) se prefere a atitude desconsolada dos que aceitam as antinomias e as ambiguidades como componentes irremediáveis da vida humana, como se dá no existencialismo; ou (3) se proclama enfaticamente a necessidade de se afastarem tais cogitações como pseudoproblemas, como fazem os neopositivistas, olvidando os pressupostos optativos que condicionam a sua atitude agnóstica; ou, finalmente, (4) se reconhece a ambivalência do ser humano, na polaridade e implicação dialética do subjetivo e do objetivo, do individual e do social, do imanente e do transcendente, buscando-se uma unidade de relação, ou melhor, de correlação, que não estanque a continuidade do processo espiritual. (gn)

Aceita esta última posição, como me parece necessário, a multiplicidade das análises e perspectivas confluem 
para a unidade essencial do homem e de sua história, razão pela qual tenho reclamado a aplicação, nos domínios da cultura, de uma dialética de complementaridade, que parte de uma prévia análise fenomenológica do real recebido hipoteticamente como um 'dado', para, a seguir, elevar-se à "reflexão históricoaxiológica", ou seja, à compreensão refletida como vigência no desenvolvimento histórico das ideias. Esse ponto é para mim essencial, embora não tenha sido sempre posto em realce pelos que me honraram com a sua atenção e a sua crítica, pois é graças a ele que o criticismo ontognoseológico se revela de caráter essencialmente histórico-axiológico. (gn)

De acordo com Morsink ${ }^{73}$, a Guerra Fria, o lobby das mulheres e a tradição do socialismo Latino Americano foram também forças importantes que contribuíram para a escritura desse documento pivotante (DUDH1948), mas nenhum deles alcança a importância do $\underline{\text { Holocausto }}$. Por essa razão, eu coloco lado a lado o conteúdo de certos artigos e as razões que as delegações deram para querer incluir os artigos na DUDH1948. O motivo que baliza as adoções e as rejeições é que a Declaração Universal foi adotada para evitar outro Holocausto ou abominação similar. Ao ouvir a respeito e experimentar os horrores da guerra, isso convenceu os autores da Declaração da adequação daquilo que eles estavam fazendo. O choque moral criado pelos nazistas deu aos redatores uma plataforma comum que eles puderam operar e fazer o documento. Enquanto eles frequentemente diferiam numa palavra ou termo específico a serem usados, uma vez que se demonstrava que a violação de certa cláusula ou artigo tinha, de alguma forma, ajudado a criar os horrores da guerra, a adoção daquela cláusula ou artigo era virtualmente assegurada. (gn)

A conexão entre o Holocausto e a DUDH1948 não é desconhecida, mas muitos detalhes apresentados aqui são novos, e eles farão, conforme Ernst Davies tinha esperança que fariam enraizar, firmemente, a conexão entre a Segunda Guerra Mundial e a Declaração Universal de Direitos Humanos. (gn)

73 MORSINK, Johannes, The Universal Declaration of Human Rights : Origins , Drafting and Intent, University of Pennsylvania Press, 1999. p.37 e sgts 
Em sua obra, Minha Luta (Mein Kampf), Adolf Hitler foi terrivelmente consistente em estender as implicações de sua perspectiva orgânica do Estado. Apesar de não ser o primeiro, ele é sem dúvida o pensador mais conhecido a tomar a palavra "orgânica" literalmente. Ele não falava apenas de uma "unidade íntima do desejo do nosso povo" e do Estado "como um organismo vivo de uma nacionalidade" e metáforas similares e frases abstratas abertas a várias interpretações que podem ofuscar seu significado. Adolf Hitler tornou tudo muito concreto ao identificar o Estado com a raça e a raça com o sangue. Ele definiu um Estado como uma "organização de uma comunidade física e psicologicamente similar de seres humanos para facilitar a manutenção da espécie deles". (gn)

Esse organicismo extremo significa uma quebra total da linha divisória entre as pessoas e seus Estados. É exatamente o oposto do que Hernan Santa Cruz, o delegado chileno ao Terceiro Comitê, disse que era o pressuposto o qual a Declaração se baseou, ou seja, na crença de que "os interesses do indivíduo vinham antes daqueles do Estado e que ao Estado não deveria ser permitido a privação do indivíduo com respeito à sua dignidade e aos seus direitos básicos" (Third,p.50).(gn) 


\subsection{0 - DEBATE HISTÓRICO-AXIOLÓGICO ENTRE NOVOS E VELHOS DIREITOS ${ }^{74}$}

Logo no início do processo de elaboração, em abril de 1946, Henri Laugier, o assistente do Secretário-Geral, encarregado dos assuntos sociais e chefe de John Humphrey, disse aos delegados do Comitê Nuclear que eles teriam de mostrar que

os direitos políticos são a primeira condição de liberdade, porém o atual progresso da civilização industrial e científica criou organizações econômicas que estão causando servidão intolerável aos homens politicamente livres, e que, portanto, no futuro, a declaração dos direitos do homem deve ser estendida aos campos econômicos e sociais (E/HR/6/p.2).

Chang, o delegado da China, também queria que

as necessidades de melhorias nas condições econômicas e sociais fossem mencionadas no Preâmbulo. Isso poderia ser feito com o empréstimo das expressões da Carta sobre o esse sujeito.

Um subcomitê foi criado e propôs duas versões para o Preâmbulo, ambas as quais continham a redação da Carta da ONU, afirmando que os povos das Nações Unidas "estão determinados promover o progresso social e melhores padrões de vida em uma liberdade mais abrangente" (E/CN.4/146 e 149). A referência de "progresso social" junto com a meta estabelecida no artigo 55, para promover "padrões mais altos de vida, pleno emprego e condições de progresso socioeconômico e desenvolvimento", foram usadas para ajudar na inclusão dos direitos econômico, sociais e culturais na declaração. Essa parte foi adotada como parte do quinto parágrafo do Preâmbulo.

74 MORSINK, Johannes, The Universal Declaration of Human Rights : Origins , Drafting and Intent, University of Pennsylvania Press, 1999. p.130 e sgts 
Como veremos a seguir, Humphrey não teve nenhuma reserva em seguir as instruções de Henri Laugier, pois ele devotou 10 artigos em seu esboço de Declaração, do H35 até a proposta normativa H44, aos novos direitos econômicos e culturais.

As nações da América Latina tiveram uma história tumultuada com mudanças agudas de ditaduras para democracias e vice-versa; mas de início muitas das suas constituições tinham incluso os direitos econômicos e sociais. Além disso, na metade dos anos 1940, parece ter havido uma confluência de fatores que tornaram possível as nações latinas falarem quase com uma única voz em matérias constitucionais. Enquanto as constituições latino-americanas sempre garantiam aos seus cidadãos uma medida de seguridade social, reescrituras e revisões eram ainda mais explícitas e detalhadas nas suas afirmações dos direitos sociais e econômicos. A constituição socialista mexicana de 1917, que surgiu da revolução, serviu como inspiração e modelo para vários outros países.

Em fevereiro de 1945, quase no fim da II Guerra Mundial, as nações das Américas realizaram a Conferência sobre a Guerra e a Paz, na Cidade do México. Nesta conferência, a delegação guatemalteca declarou que

a Segunda Guerra Mundial tinha criado uma demanda em todo o mundo de que os direitos do homem devessem ser reconhecidos e protegidos em nível internacional; logo, o movimento interamericano deveria apoiar esse anseio universal, ao reconhecer que regimes antidemocráticos eram as primeiras causas de negação dos direitos humanos e das liberdades. (gn)

Muitas das delegações latino-americanas, que tinham favorecido a proposta guatemalteca, levaram suas preocupações para a Conferência de São Francisco, em maio de 1945, onde as Nações Unidas estavam sendo organizadas. As nações latinoamericanas juntaram-se a numerosas organizações não governamentais e fizeram vigorosos lobbies, mas não exitosos, para a inclusão de uma carta de direitos na Carta das Nações Unidas. Os primeiros três governos que submeteram cartas de plenos direitos para a Comissão de Direitos Humanos, posteriormente constituída, foram Panamá, Chile e Cuba. Os rascunhos que esses países submeteram todos continham direitos a: educação, trabalho, comida, assistência de saúde e outras provisões de seguridade social. 
Essas três minutas junto com aquela submetida pela Federação Americana de Trabalho, que incluíam provisões similares, foram os primeiros rascunhos que a equipe de Humphrey comparou e preparou para estudo pela Comissão de Direitos Humanos. Por causa dessas oportunas contribuições, os direitos sociais, econômicos e culturais entraram desde o início do processo de elaboração.

A proposta normativa panamenha foi preparada pelo Instituto Americano de Direito (ALI); os cubanos escreveram sua própria, e a proposta chilena foi preparada pelo Comitê Jurídico Interamericano da Organização dos Estados Americanos (OEA), que tinha recebido o mandato da Conferência do México para escrever esse rascunho. $\mathrm{Na}$ preparação de seu esboço geral para a CDH, Humphrey fez bastante uso dessas submissões prévias, especialmente a panamenha e a chilena.

A tabela 1, abaixo, mostra que Humphrey aproveitou da redação e de quase todas as ideias para os direitos sociais, econômicos e culturais de seu primeiro rascunho da tradição socialista latino-americana por intermédio das propostas normativas submetidas pelo Panamá (ALI) e pelo Chile (OEA). Depois que Humphrey tinha inserido os novos direitos no rascunho da Declaração, ele retirou-se, apropriadamente, do processo decisório e tornou-se o facilitador do trabalho da Comissão pelo Secretariado.

Analisa Morsink que

é impossível exagerar a importância do fato de que, desde o início, o ônus da prova estava com aqueles que queriam suprimir certos artigos. Quando essas tentativas eram feitas, os delegados latino-americanos garantiam que aquilo que Humphrey tinha posto na proposta fosse mantido. Entre esses guardiões dos novos direitos, Santa Cruz, o delegado chileno, foi o maior, e ele e Humphrey tinham uma excelente relação social e de trabalho. 


\begin{tabular}{|c|c|c|c|}
\hline \multicolumn{2}{|c|}{ Adobe Digital Editions } & \multicolumn{2}{|c|}{9780812217476 ePDF.pdf } \\
\hline \multirow{14}{*}{ EHE } & LEITURA & $132(147 / 394)$ & 圆圆回區 \\
\hline & \multicolumn{3}{|c|}{132 Chapter 4} \\
\hline & \multicolumn{3}{|c|}{$\begin{array}{l}\text { TABLE 1. Social and Economic Rights in Humphrey's First Draft of the Declaration } \\
\text { of Human Rights }\end{array}$} \\
\hline & Article & Right & Source ${ }^{\mathrm{a}}$ \\
\hline & H35 & To health care & Inter 16 , exact \\
\hline & H36 & To an education & ALI 11, exact \\
\hline & H37 & And duty to do "socially useful work" & Inter 14; ALI 12 \\
\hline & H38 & To good working conditions & ALI 13, exact \\
\hline & H39 & $\begin{array}{l}\text { To an "equitable share of the national } \\
\text { income as the need for his work and } \\
\text { the increment it makes to the common } \\
\text { welfare may justify" }\end{array}$ & New; Cuba 9; AFL 3 \\
\hline & $\mathrm{H} 40$ & $\begin{array}{l}\text { To "such public help as may be necessary } \\
\text { to make it possible for him to support } \\
\text { his family" }\end{array}$ & Inter 10 and 16 ; Cuba 10 \\
\hline & H41 & $\begin{array}{l}\text { To "social security" and protection against } \\
\text { the risks of "unemployment, accident, } \\
\text { disability, sickness, old age and other } \\
\text { involuntary or undeserved loss of liveli- } \\
\text { hood" }\end{array}$ & ALI \#, exact; Inter 16; AFL 3; Cuba 10 \\
\hline & $\mathrm{H} 42$ & $\begin{array}{l}\text { To "good food and housing" and "healthy } \\
\text { surroundings" }\end{array}$ & ALI 14, exact; Cuba 11 and 12, exact \\
\hline & $\mathrm{H} 43$ & To "a fair share of rest and leisure" & $\begin{array}{l}\text { New (but in numerous Latin American } \\
\text { constitutions) }\end{array}$ \\
\hline & H44 & $\begin{array}{l}\text { To "participate in the cultural life of the } \\
\text { community, to enjoy the arts and to } \\
\text { share in the benefits of science" }\end{array}$ & New; Inter 15 , exact \\
\hline
\end{tabular}

Source: AC. $1 / 3$ and W.8.

a Designations refer to drafts by the American Law Institute (ALI) for Panama; the Inter-American Juridical Committec (Inter) for Chile; the American Federation of Labor (AFL); and Cuba. The designation "exact" is included for instances in which Humphrey borrowed all or most of his phraseology from his source.

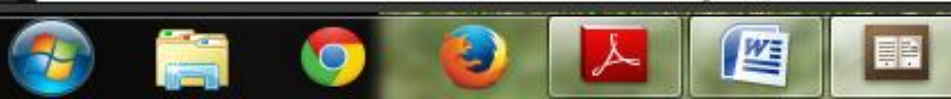

A proposta guatemalteca feita na Cidade do México durante a Conferência da Guerra e da Paz foi enviada ao Comitê Jurídico Interamericano para estudo e consideração. Quando o Comitê deu seu relatório para a Nona Conferência Internacional de Estados Americanos, realizada em Bogotá em abril de 1948, ele não apoiou a proposta guatemalteca, mas, nessa mesma conferência, foi adotada a Declaração Americana de Direitos e Deveres do Homem, também conhecida como Declaração de Bogotá. O Preâmbulo da Carta de Bogotá, para a recém constituída Organização de Estados Americanos, demandava a "consolidação neste continente, dentro do marco das instituições democráticas, de um regime de liberdade individual e de justiça social, fundado no respeito dos direitos essenciais do homem". 
A Declaração de Bogotá também dá igualdade normativa para a liberdade e a justiça social.

Morsink apressa-se em dizer que a conexão entre a Declaração Americana e a Carta de Bogotá com a Declaração Universal não é direta.

Os novos direitos econômicos e sociais não foram transferidos de Bogotá para Paris num só golpe. Isso não poderia ter acontecido, porque, quando os novos direitos foram introduzidos pioneiramente nos rascunhos prévios da Declaração Universal entre junho e dezembro de 1947, a Declaração de Bogotá de abril de 1948 ainda não tinha sido redigida.

O que é verdade, porém, é que, em 1948, as Nações latino-americanas estavam engajadas na redação de duas cartas de direitos, a de Bogotá para sua região, e a outra das Nações Unidas. Quase todos os países enviaram delegados para ambos eventos. O quadro acima demonstra que os direitos sociais, econômicos e culturais foram peças aceitáveis do acervo constitucional na América Latina dos anos 1940 e que a Declaração Universal foi - apesar de não ter sido modelada de acordo com a Declaração de Bogotá em que direitos e deveres do indivíduo foram definidos - grandemente influenciada por esse precedente e pela tradição que se espraiou da Declaração de Bogotá.

Vejo a conexão entre Humphrey e o bloco de votação latino como um momento fortuito na história, quando o Espírito do Mundo de Hegel fez de um temperamental professor canadense de direito dar um passo gigantesco em frente da dialética da história. Alguém com uma base diferente e com uma diferente persuasão filosófica poderia ter preparado o primeiro esboço normativo sem incluir quaisquer provisões sociais e econômicas. Essa pessoa que não Humphrey poderia ter visto o que as nações latino-americanas ofereceram e ignorado ou mesmo combatido. $\mathrm{O}$ empréstimo de Humphrey não foi o do tipo feito às escuras. Ele foi, 
de fato, a pessoa perfeita a fazer essa conexão.

Até as votações finais, havia muitas delegações que hesitaram em incluir esses direitos não tradicionais, mas elas nunca tiveram nem as razões lógicas nem os votos para transformar essas reservas mais ou menos privadas na política dominante da redação. Os delegados da Austrália e do Reino Unido achavam que era melhor deixar os novos direitos para um pacto posterior, mas Santa Cruz do Chile discordou avançando o seguinte argumento:

os direitos econômicos, sociais e culturais devem ser mencionados não apenas nos artigos da Declaração, mas também no Preâmbulo, de forma a dar-lhes importância adequada (AC.1/SR.9/p.10).

Sob o patrocínio de Santa Cruz, os novos direitos foram lidos e devidamente registrados, ao invés de serem lidos rapidamente e em bloco, depois de a presidenta da $\mathrm{CDH}$, Eleanor Roosevelt, ter relembrado ao Comitê Redator que :

o Conselho Econômico e Social, órgão dirigente da Comissão de Direitos Humanos, destacou a importância de se considerar a inclusão dos novos direitos.

A Segunda Sessão da Comissão teve de fazer uma escolha entre usar o texto Humphrey/Cassin como base para as suas discussões ou a proposta normativa britânica. Uma vez que o rascunho britânico não incluía nenhum direito econômico, social e cultural, a escolha da Segunda Sessão envolvia uma decisão sobre o status jurídico dos novos direitos.

Bogomolov, representante da União Soviética, falou contra a proposta de convenção britânica, porque ela não incluía o que sua delegação considerava como os direitos "mais simples e mais essenciais", como "o direito ao trabalho, ao lazer, à educação, à segurança social e à inviolabilidade da pessoa humana" (SR.42/p.12). 
Charles Dukeston do Reino Unido respondeu às críticas de Bogomolov com o argumento segundo o qual :

os direitos econômicos e sociais e a segurança social têm como suporte primário a afirmação da liberdade de expressão e do direito de associação. Assim, a condição prévia essencial era de criar as bases das liberdades fundamentais [...] Se esses direitos e liberdades proclamados na presente carta tornarem-se uma realidade, eles contribuirão para a gradual constituição de outras liberdades [...] Em nenhum país democrático, houve desenvolvimento da liberdade de outra forma. Os direitos humanos desenvolveram-se primariamente mediante o reconhecimento da liberdade de expressão, da liberdade de associação, da liberdade de pensamento, então positivadas no Direito [...] O mundo necessitava de homens livres, e não de escravos bem alimentados; logo, no desenvolvimento dos direitos humanos, era preciso começar pela proclamação das liberdades de expressão, de associação e de pensamento, sem as quais, os direitos humanos não poderiam ser desenvolvidos. ${ }^{75}$

Nessa exposição, Dukeston expressou a opinião não incomum, até o presente momento na diplomacia parlamentar, de que os direitos civis e políticos são muito mais importantes do que os direitos econômicos, sociais e culturais, porque aqueles são um pré-requisito para os últimos, mas os direitos econômicos não o são para aqueles. (gn)

Klekovkin, representante da República da Ucrânia, defendeu a opinião contrária, segundo a qual os novos direitos eram mais importantes do que os antigos. Ele pensou que a convenção faltava com sinceridade. Em suas palavras:

A declaração lidava, apenas, com um aspecto dos

75 MORSINK, Johannes, The Universal Declaration of Human Rights : Origins , Drafting and Intent, University of Pennsylvania Press, 1999. p 223 e segts 
direitos humanos e desconsiderava, completamente, os direitos econômicos, como direitos de sindicalização, segurança social, prevenção do desemprego [...] que eram a fundação de todos os outros direitos. A Comissão de Direitos Humanos tinha esquecido que aqueles instrumentos em formação destinavam-se à grande massa de trabalhadores, cujas perspectivas sobre a vida tinham mudado consideravelmente, desde a Guerra Mundial [...] A Convenção confirmava a verdade da expressão que ele tinha ouvido nos Estados Unidos: "Homens são livres, mas estão morrendo de fome". O homem ordinário somente estava interessado na liberdade de pensamento e na liberdade de imprensa, quando ele estava protegido contra a pobreza; porém a Convenção não fornecia nenhuma garantia de condições de vida materiais (SR.42/p.16).

Uma votação nominal foi feita sobre a aceitação do rascunho da Convenção como um texto para discussões posteriores. Aqueles que (ainda) não aceitaram o status jurídico igualitário de todos os direitos humanos votaram pela aceitação da convenção conforme ela tinha sido submetida, ou seja, sem os direitos econômicos, sociais e culturais nela. Essas delegações ou se opunham, em princípio, a esse tipo de responsabilidade ou elas achavam que o tempo não estava maduro.

A Segunda Sessão adotou a convenção por 10 votos a 4 , com 4 abstenções. Votando pela convenção estavam: Bélgica, China, Egito, França, Índia, Irã, Líbano, o Reino Unido, os Estados Unidos e o Uruguai. Votando contra estavam: a República da Bielorrussia, a União Soviética, a República da Ucrânia e a Iugoslávia. As abstenções foram da Austrália, do Chile, do Panamá, e das Filipinas. Com exceção da Austrália, não dá para saber como as nações que abstiveram teriam votado, e pode ser significativo que elas estavam ausentes, ao invés de presentes e escolhendo a abstenção.

Na Segunda Sessão de Elaboração, os australianos vieram com uma proposta corajosa de incluir os direitos sociais e econômicos no rascunho do Pacto. Eles disseram que a proposta deles

estava projetada para incluir no Pacto certos 
direitos legais, econômicos e sociais que tinham sido reconhecidos no rascunho da Declaração, mas omitidos do rascunho do Pacto. A lógica para essa inclusão era de que a liberdade da miséria, a terceira das Quatro Liberdades, tinha sido amplamente aceita no mundo. $\mathrm{Na}$ presente fase na história mundial, os povos estão especialmente interessados nos direitos econômicos e sociais, assim como nos políticos. Era importante incluí-los, de forma a dar uma afirmação completa e equilibrada ao Pacto. A convenção deveria representar uma garantia de direitos que diziam respeitos ao homem comum; o pacto não deveria ser elaborado com base na negação de direitos de acordo com a perseguição nazista (SR.29/p.2).

Relata-nos Morsink que as reações das delegações diferiram. Sender da Federação Americana de Trabalho concordou que "a opinião pública no presente momento estava interessada, prioritariamente, nos direitos econômicos e sociais". Santa Cruz, o delegado chileno, também pensou que "os direitos econômicos e sociais eram especialmente importantes no mundo moderno e não poderiam ser omitidos da primeira Convenção". Wu da China e Cassin da França eram simpáticos à ideia, mas sentiam que o tempo não era propício e que era muito tarde para fazer mudanças desse porte naquela fase da elaboração de um Pacto. Outras delegações opuseram-se mais claramente. Malik do Líbano era da opinião que :

havia [...] uma diferença essencial entre governos expressando crenças nos ideais e entre os próprios governos responsabilizarem-se, internacionalmente, pela realização deles. Todo o controle governamental que seria preciso para realizar os direitos novos significaria a destruição das instituições livres num mundo livre. Os governos deveriam prezar somente pela manutenção das condições materiais de liberdade.

Morsink pondera que essas sementes de libertarismo não se enquadravam com as credenciais católicas de Malik, no entanto elas eram coerentes com sua oposição consistente a quaisquer obrigações estatais na Declaração. 
Roosevelt tinha a mesma opinião de Malik. O pacto deveria ser para todos os Estados, e não apenas para um Estado progressista como a Austrália. Além disso, ela acreditava que

era mais vantajoso incluir afirmações de ideais, de esperanças e de aspirações na Declaração, que era um tipo de documento educacional, do que num Pacto, que deveria incluir aquelas provisões as quais os governos pudessem sentir-se responsáveis de pôr em prática.

Como patrocinador de um Pacto com um tipo de direito apenas, Wilson, delegado britânico, reiterou que

havia uma distinção entre direitos humanos e liberdades fundamentais de um lado, e aquelas coisas que eram necessárias para o desenvolvimento completo da vida individual. Levaria muito tempo, se o Comitê tentasse definir todas as necessidades para o desenvolvimento de uma vida plena, além e acima dos direitos humanos e das liberdades fundamentais.

A Segunda Sessão de Redação rejeitou a proposta de incluir os novos direitos no Pacto por 2 votos a 3, com 3 abstenções. Dos comentários feitos durante os debates, Morsink constituiu o seguinte placar: Austrália e Chile votaram a favor, Reino Unido, Estados Unidos e Líbano votaram contra, França, China e União Soviética abstiveram-se. $^{76}$

Mais tarde, na Terceira Sessão, os Estados Unidos, o Reino Unido e o Líbano levantaram objeções com respeito à adoção do artigo 22. Como razões, eles deram que esse artigo dava muita atenção aos novos direitos, mas eles não repetiram o que disseram na Segunda Sessão de Redação que os novos direitos eram de segunda classe e mesmo nem considerados "direitos". Como os motivos revelados até aqui provavelmente tiveram importância para essas objeções posteriores, Morsink rotula a posição anglo-americana com respeito à distinção entre velhos e novos direitos como uma posição

76 ibidem. p. 225 . 
maligna: como sendo a posição deles aquela que os novos direitos são intrusos no domínio dos direitos e que não merecem o mesmo status normativo dos mais antigamente estabelecidos. A maioria das delegações, por sua vez, tinha uma perspectiva mais benigna da distinção, somente por causa de os novos direitos terem a necessidade de serem mais cultivados e promovidos como sendo novos na família dos direitos.

A presença de vários dos novos direitos na Declaração foi garantida por causa de uma iniciativa socialista Latino-Americana com a assistência comunista. A composição de um subcomitê para resolver o problema da rejeição total do artigo sobre o direito ao trabalho no Terceiro Comitê demonstra que, se as delegações do Atlântico Norte e seus aliados tivessem querido bloquear a agenda socialista, eles provavelmente teriam conseguido. Pelo fato de não a terem bloqueado é um testemunho da unidade dos direitos na Declaração Universal de Direitos Humanos. 


\title{
1.11 - A UNIDADE ORGÂNICA DA DECLARAÇÃO UNIVERSAL DE DIREITOS HUMANOS E O DIREITO AO PLENO DESENVOLVIMETO DA PERSONALIDADE
}

\begin{abstract}
A discussão com respeito à importância relativa dos "velhos" contra os "novos" direitos convida-nos a alargar nossa investigação e nos perguntarmos como os autores viam a inter-relação de todos os direitos e artigos na Declaração em geral. Afirma Morsink $^{77}$ que:
\end{abstract}

a maioria dos autores da Declaração acreditava que o lugar exato de um artigo não era crucial para o seu significado, uma vez que era necessário interpretar o artigo à luz de todo o contexto.

Em relação aos direitos econômicos, sociais e culturais, diz Morsink ${ }^{78}$ que o Holocausto e os horrores nazistas não desapareceram de vista, instantaneamente, para nunca mais serem vistos novamente. Os elaboradores da Declaração consideraram todos os direitos e os artigos da Declaração como tendo uma unidade orgânica. Os autores alertam-nos contra a leitura muito referente à posição de certos artigos na lista de direitos. Esses artigos e suas posições foram amadurecendo ao longo dos dois anos e meio do período de elaboração nomotética e cada um deles deve ser interpretado à luz de todos os direitos restantes. Isso significa que, por exemplo, o raciocínio para o direito à vida contém as coisas que as pessoas necessitam (comida, moradia, vestuário, saúde, educação e trabalho) para, primeiro, simplesmente manter-se viva (sobreviver) e, então, para adquirir um padrão descente de vida para si e para suas famílias. (gn)

Muitos dos direitos humanos estão conectados com o direito humano fundamental de todos ao desenvolvimento livre e pleno de sua personalidade, conforme listado nos artigos $222^{79}$ e $29^{80}$ da DUDH1948. Os redatores tinham plena consciência do contraste entre esse direito mais básico (direito ao livre e pleno

\footnotetext{
${ }^{77}$ ibidem, p.232 e sgts

78 MORSINK, Johannes, The Universal Declaration of Human Rights : Origins , Drafting and Intent, University of Pennsylvania Press, 1999. p.88 e sgts

79 Artigo 26,2: A instrução será orientada no sentido do pleno desenvolvimento da personalidade humana e do fortalecimento e do respeito pelos direitos humanos e pelas liberdades fundamentais. A instrução promoverá a compreensão, a tolerância e a amizade entre todas as nações e grupos raciais ou religiosos, e coadjuvará as atividades das Nações Unidas em prol da manutenção da paz.

${ }^{80}$ Artigo 29,1: Toda pessoa tem deveres para com a comunidade, na qual o livre e pleno desenvolvimento de sua personalidade é possível.
} 
desenvolvimento da personalidade) com as práticas do Terceiro Reich. Eles pensaram em expandir o que é o presente artigo 3, para incluir o direito ao desenvolvimento da personalidade que teria trazido todos os direitos econômicos, sociais e culturais para o início da Declaração. (gn)

O artigo 3 da DUDH1948 chegou ao Terceiro Comitê como se lê:

"Todos têm o direito à vida, à liberdade e à segurança pessoal" (A/C.3/259).

Apesar da grande semelhança entre este artigo e o do texto de Bogotá, que também falava de "segurança pessoal", várias delegações latino-americanas propuseram emendas que expandiriam o artigo 3 para incluir uma referência explícita aos direitos econômicos, sociais e culturais. Esses esforços culminaram em uma emenda proposta em conjunto pelas delegações do Uruguai, de Cuba e do Líbano. Elas propuseram a seguinte emenda:

Todos têm o direito à vida, à liberdade, à segurança pessoal e às condições econômicas e outras necessárias para o pleno desenvolvimento da personalidade humana (A/C.3/274/Rev.1).

A principal objeção à essa proposta de expansão do artigo 3 era que ela conflitava com o fluxo lógico dos artigos. Chang, o delegado chinês, que mais argumentava por essa linha, via a serventia de trazer os direitos econômicos, sociais e culturais à frente e de tornar o que era o artigo 22 parte do artigo 3. Entretanto, Chang insistiria que o novo texto devesse ser posto em um parágrafo separado de forma a realçar sua importância. Disse Chang que ele "votaria contra a emenda conjunta, porque ele considerava ser incorreto expressar dois conjuntos de ideias em um único parágrafo" ${ }^{81}$.

\footnotetext{
${ }^{81}$ Veremos que a delegação cubana era da opinião de que a ordem dos artigos como estava "não considerava propriamente certos direitos". Em particular, disse Pérez Cisneros, os direitos sociais, que foram a conquista do século XX, deve, numa declaração do século XX, preceder os direitos legais, adquiridos há muito e repetidos em vários documentos similares". Os direitos sociais, econômicos e culturais devem receber, disse ele, um "lugar de honra".

Durante a primeira tentativa cubana de remediar esse problema, sua proposta de mover a última cláusula do presente artigo 22 no artigo 3, Chang, o delegado chinês, fez alguns comentários reveladores sobre co mo ele via a estrutura da DUDH.
} 
Além disso, ele nunca propôs, formalmente, a fusão do que é o atual artigo 22 como um parágrafo separado do artigo 3. Seu apoio foi para o outro lado, pois a emenda conjunta foi rejeitada por 21 votos a 20, com 12 abstenções. Os autores decidiram contra esse movimento, porque eles sentiram que o direito ao desenvolvimento da personalidade estava coberto pela frase "segurança pessoal".(gn)

A razão dessa aparente evasiva é de mostrar que o direito ao "pleno desenvolvimento da personalidade humana" positivado no artigo 3 era visto, pela maioria dos delegados, como uma forma de sumariar todos os direitos econômicos, sociais e culturais na Declaração. (grifos nossos)

Chang opôs-se à mudança do artigo 22 para o artigo 3, porque, disse ele, "os Artigos 1,2 e 3 expressavam as três principais ideias da filosofia setecentista; o artigo 1 expressava a ideia de fraternidade, o artigo 2 a de igualdade e o 3 a de liberdade". A ideia de liberdade, então, foi aplicada primeiro ao indivíduo, depois para a família e por último para a sociedade. Depois disso, "o artigo 22, como o artigo 3, expressava uma ideia geral que foi explicada e desenvolvida nos artigos seguintes". Chang achava que a emenda para fundir 22 no 3 era "fora de conexão com aquela estrutura, que era de progressiva e de abrangente liberdade".

Para Cassin, delegado francês, por sua vez, a Declaração tinha a seguinte estrutura: "Os dois artigos iniciais afirmavam princípios gerais dentre de uma moldura segundo a qual os direitos individuais eram definidos. Havia uma progressão regular dos direitos individuais para os direitos sociais. Entre essas duas categorias, vinha o primeiro grupo de artigos lidando com a proteção física do indivíduo, então, um grupo lidando com a relação do homem com seus companheiros e com as coisas - família, residência, fronteiras, nacionalidade e, finalmente, propriedade- então vieram os artigos lidando com as grandes liberdades públicas, inclusive a liberdade religiosa, e suas manifestações externas nas formas de liberdade de expressão; e os últimos artigos 22 ao 27 proviam as garantias de segurança social".

A ideia de uma estrutura lógica sugere que certos direitos têm uma prioridade lógica sobre outros que seguem, mas isso é precisamente o ponto de vista (com a possível exceção do direito à vida) que a maioria dos delegados não aceitou.(gn)

Os EUA tinham sido os proponentes da perspectiva de que não havia uma classificação inerente dos direitos na DUDH em termos de sua importância. Há conjuntos de artigos lidando com certos temas comuns, como direito legais e direitos relativos ao trabalho, mas não há uma "corrente lógica" que demanda que um conjunto vem antes ou é um pré-requisito para outro conjunto. Os conjuntos e os artigos individuais todos implicam-se uns aos outros.

Um ano mais tarde, na época das discussões sobre a ordem dos artigos no Terceiro Comitê, as delegações do Líbano e dos EUA ainda tinham a mesma opinião, que foi uma razão de elas não terem apoiado a proposta cubana de reorganizar o conjunto. Roosevelt, dos EUA, "manteve que todos os artigos na DUDH tinham a mesma importância independentemente de suas posições. O ponto importante era que os direitos devem ser agrupados de uma forma que eles sejam inteligíveis para a pessoa que lê o documento. A DUDH deveria fazer um impacto como conjunto, não havia como tentar dar prioridade a um ou outro artigo".

Esse parece ter sido o consenso da maioria. Os comentários de Eleanor e as votações sobre as propostas cubanas apontam nessa direção. Isso significa que não havia consenso sobre a existência de uma estrutura fundamental da DUDH. O documento tinha amadurecido organicamente e a maioria dos redatores pôde concordar que havia alguns conjuntos soltos de artigos in MORSINK, Johannes, The Universal Declaration of Human Rights : Origins , Drafting and Intent, University of Pennsylvania Press, 1999. p.234/236 
Os proponentes da emenda conjunta do artigo 3 sentiam que, ao adicionar o direito ao desenvolvimento pessoal aos direitos já presentes, como o direito à vida, à liberdade e à segurança pessoal, eles estavam, com efeito, trazendo toda a segunda metade do documento à frente mediante o artigo 3. Esse é o contexto da emenda cubana ao artigo 22. Após ter perdido a batalha acerca do artigo 3, a delegação cubana tentou novamente com o artigo 22 e teve êxito em mudá-lo para a disposição presente que afirma que "a realização...dos direitos econômicos, sociais e culturais é indispensável para a dignidade e o livre desenvolvimento da personalidade". Esse êxito de mudar o final da redação do artigo 22 foi uma das muitas tentativas da delegação cubana de melhorar o status dos novos direitos econômicos, sociais e culturais na Declaração.

Relata Morsink que :

não houve um longo debate, mas das discussões prévias sobre a extensão do artigo 3, sabemos que o significado desse direito abstrato ao pleno desenvolvimento queria dizer para os autores. Junto com os outros direitos expressos no artigo 3, os autores da Declaração consideravam-no um dos direitos humanos mais fundamentais no documento. A maioria dos artigos seguintes ao 22 - aqueles listados do artigo 23 até o 27 visam à realização do direito ao pleno desenvolvimento de uma pessoa. (gn)

O direito ao pleno e livre desenvolvimento da personalidade é um dos pontos principais que o artigo 22 traz, e ele pode nos ajudar a nos concentrar na nomogênese do direito à alimentação na carta internacional de direitos humanos.

Na literatura sobre direitos humanos, o direito ao "autodesenvolvimento" é usado com frequência para referir-se ao direito das nações à autodeterminação ${ }^{82}$.

${ }^{82}$ MORSINK, Johannes, The Universal Declaration of Human Rights : Origins, Drafting and Intent, University of Pennsylvania Press, 1999. p210 e sgts 
No primeiro artigo de ambos Pactos Internacionais de Direitos Humanos, afirma-se que:

Todos os povos têm direito à autodeterminação. Em virtude desse direito, os povos determinam livremente seu estatuto político e asseguram livremente seu desenvolvimento econômico, social e cultural".

O segundo parágrafo também é o mesmo em ambos Pactos e explica que esse direito significa que:

Para a consecução de seus objetivos, todos os povos podem dispor livremente de suas riquezas e de seus recursos naturais, sem prejuízo das obrigações decorrentes da cooperação econômica internacional, baseada no princípio do proveito mútuo e do Direito Internacional. Em caso algum, poderá um povo ser deprivado de seus próprios meios de subsistência.

De acordo com Morsink, esses artigos dos dois Pactos são o cerne das discussões do que é chamado, com frequência, de terceira geração de direitos humanos (coletivos), a primeira geração sendo os direitos (individuais) civis e políticos clássicos, e os de segunda geração os direitos (individuais) sociais, econômicos e culturais.

Esse direito de terceira geração à autodeterminação ou autodesenvolvimento com respeito aos povos é equiparado, na DUDH1948, com o direito de segunda geração, os quais os redatores chamaram de direito ao pleno desenvolvimento dos indivíduos. No decorrer do estudo da nomogênese do direito à alimentação, veremos que o significado do artigo 25 relaciona-se às circunstâncias de que, em nenhuma hipótese, um indivíduo possa ser deprivado dos meios de subsistência dele. Além da subsistência, o direito ao livre e pleno desenvolvimento da personalidade envolve os direitos ao trabalho, à livre escolha do emprego e à proteção contra o desemprego, todos pertencentes ao artigo 23. Esse direito ao desenvolvimento da personalidade também inclui os direitos a condições justas e favoráveis de trabalho, conforme estipulados no restante do artigo 23 e nos artigos 24 e 25 . 
O único lugar nas proposições normativas pioneiras em que a frase e o direito ao "pleno desenvolvimento" ocorreram foi no rascunho submetido pela Federação Trabalhista Americana. Em seu preâmbulo, esse documento afirmava, de forma corajosa, que :

o Estado não tem outro propósito que o bem de seus membros individuais, no presente e no futuro - seu teste supremo é o modo como o Estado proporciona pleno e livre desenvolvimento de cada indivíduo. Quanto mais direitos forem usufruídos pelos indivíduos, mais democrática será a sociedade (W.8/p.2).

Cogita Morsink que Humphrey não sentiu necessidade de afirmar esse direito separadamente em sua proposta normativa, porque o direito ao desenvolvimento permeava toda a perspectiva socialista dele e estava evidenciado nos vários artigos que ele submeteu. Enquanto Humphrey foi muito explícito sobre os meios que pudessem implementar o direito ao autodesenvolvimento, ele esqueceu-se de afirmá-lo explicitamente.

Cassin corrigiu essa omissão, ao adicionar "o direito ao pleno desenvolvimento de sua personalidade" ao artigo de Humphrey sobre "o direito e o dever de fazer trabalhos socialmente úteis"(W.2/Rev.2). E, provavelmente, ainda ressoando a submissão da Federação Trabalhista Americana, Cassin também submeteu como seu segundo artigo a alegação de que:

o objeto da sociedade é proporcionar a cada um de seus membros oportunidades iguais para o pleno desenvolvimento de seu espírito, de sua mente e de seu corpo (W.2/Rev.2).(gn) 


\subsection{2 - A NOMOGÊNESE DOS DIREITOS ECONÔMICOS, SOCIAIS E CULTURAIS COMO GÊNERO NORMATIVO DO DIREITO À ALIMENTAÇÃO E DE OUTROS DIREITOS BÁSICOS}

Os artigos 22 e 28 são gêmeos e, como propostas normativas, foram trazidas à tona bem tarde no processo de redação da DUDH1948. Ambas propostas decorrem da discussão na Terceira Sessão sobre o direito de todos ao trabalho (artigo 23) e ao dever correlativo do Estado de ajudar a encontrar esse trabalho por meio do combate ao desemprego. As delegações comunistas e britânica insistiram que os deveres dos Estados devessem ser explicados no próprio artigo 23, enquanto outras delegações, que eram a maioria, pensaram que os deveres do Estado devessem ser mencionados em outro artigo que não o 23. Daí, surgiu o artigo 22 da DUDH. (gn)

Segundo Morsink, há dois modos de interpretar o artigo 22.

Um modo maligno faz dos novos direitos não tão importantes quanto os direitos civis e políticos. A evidência para isso seria o fato de que os redatores pensarem ser necessário qualificar esses novos direitos de formas que eles não tinham qualificado os direitos adotados previamente. As frases "como membros da sociedade" e "de acordo com a organização e os recursos de cada Estado" podem ser entendidas como esses qualificadores.

De acordo com uma leitura benigna, esses direitos novos são tão importantes quanto os antigos direitos civis e políticos. Eles requerem atenção especial, precisamente porque eles são novos e porque eles são iguais, porém diferentes. Como nossa breve história sobre essa distinção nos levará a esperar, os votos de várias delegações refletiram ambas posições. 
Na Primeira Sessão de Redação, Cassin, representante francês, argumentou que os compromissos dos Estados com respeito aos direitos econômicos e sociais "não poderiam ser os mesmos que os direitos fundamentais do ser humano. A maioria dos Estados concordaria que a liberdade de consciência ou do direito à vida devessem ser salvaguardados assim que possível, mas poucos deles concordariam com compromissos detalhados em relação à segurança social, pleno emprego e outros temas". Isso tornou esses direitos inapropriados para a inclusão na Convenção, mas Cassin não se opunha a inclusão deles na Declaração, pois ele achava que o tempo estava propício.

Disse Cassin à Terceira Sessão da Comissão que:

a Comissão devesse seguir o exemplo que pode ser encontrado em todas as constituições adotadas recentemente. e devesse tratar os novos direitos separadamente dos direitos individuais. Os direitos econômicos, sociais e culturais, de modo a serem plenamente realizados, requeriam assistência material a ser proporcionada pelos Estados, uma diferença prática que a Declaração não podia ignorar. (gn)

Cassin não concordou com o representante britânico de que a inserção de um artigo de cobertura que precedesse os direitos econômicos e sociais sobrerrepresentaria a importância desses novos direitos. A Comissão meramente seguiria o método que ela tinha usado para conectar os direitos dos indivíduos (SR.72/p.4). O método era de inscrever na Declaração os principais direitos, naquele momento, presentes nas constituições do mundo. Cassin sentia, e a pesquisa de Humphrey havia lhe dito, que os novos direitos satisfaziam esse critério, mas uma vez que eles eram diferentes por requisitarem mais recursos materiais do Estado, ele propôs o artigo 22. (gn)

Malik, o representante libanês, opunha-se a um "tratamento preferencial", segundo o qual ele disse que o artigo 22 conferia aos direitos econômicos e sociais. Cassin respondeu-o que:

o texto de cobertura (artigo 3) que se aplicava aos direitos fundamentais não continha uma garantia, porque os direitos à vida e à liberdade era incondicionais. A realização dos direitos 
econômicos, sociais, por sua vez, envolvia assistência material e, portanto, requeria um garantia. Não havia intenção de pôr ênfase indevida nos novos direitos; a intenção era, meramente, reconhecer a importância deles. Era digno de nota que todos os Estados, que tinham reescrito suas constituições nos últimos trinta anos (19101948), tinham dado atenção especial e em separado para os direitos econômicos e sociais.

Cassin defendeu uma menção especial no artigo 22 - ao invés de no artigo 25 - do direito à segurança social e outros direitos sociais e econômicos, porque:

o bem-estar dos trabalhadores há muito tempo tinha deixado de ser puramente uma preocupação nacional; a massa de desempregados de 1932 mostrou que ação era necessária em nível internacional. A cláusula referente à cooperação internacional no texto do artigo satisfaria essa necessidade.

Ao refletir sobre o décimo aniversário da DUDH1948, Cassin disse em palestra realizada em 1958 que, em razão de os direitos serem "em um certo sentido indivisíveis" dos antigos direitos civis e políticos, os novos direitos econômicos, sociais e culturais tinham sido incluídos na Declaração". Esse é um relato acurado do que a maioria dos autores pensava e do raciocínio para a adoção do artigo 22 . A maioria dos autores tinha uma perspectiva benigna da distinção de direitos, e como Cassin, eles acreditavam que os direitos sociais, econômicos e culturais requeriam mais envolvimento material e necessitavam de atenção, porque eram muito novos. Em todo o processo decisório, nunca houve consenso sobre o caso de esses novos direitos serem, de alguma forma, menos importantes do que os antigos direitos e que a violação deles não era séria. Enquanto algumas delegações poderiam ter essa opinião depreciativa, as votações para incluir os novos direitos na Declaração foram bastante favoráveis, e na maioria delas muito contundentes. Por exemplo, somente os Estados Unidos votaram contra o artigo relacionado aos direitos do trabalho. Essa leitura benéfica do artigo 22 tem suporte nas reações de um texto alternativo patrocinado pela União Soviética.(gn) 
A União Soviética estava preocupada com a possibilidade de o artigo 22 levar a uma leitura maligna da Declaração, no sentido de dar aos novos direitos um status normativo inferior, de segunda classe no domínio do Direito. Por essa razão, a delegação soviética propôs um texto mais equilibrado. Pavlov, o delegado soviético, disse que:

seria incorreto ter um artigo de cobertura realçando a realização dos direitos econômicos e sociais, ao menos que os outros direitos mencionados na Declaração fossem também cobertos. Quando votei em favor da ideia de um artigo de cobertura, pensei que fosse ser aplicado para todos os direitos, muito embora uma ênfase particular fosse posta na realização dos direitos econômicos, sociais e culturais, os quais tinham sido mais recentemente reconhecidos pela história (SR.72/p.8).

Pavlov, então, reformulou e propôs para adoção o seguinte texto iugoslavo :

O Estado e a sociedade deverão empreender todas as medidas necessárias, incluindo legislação, para garantir a todas as pessoas possibilidades reais de gozo de todos os artigos listados nesta Declaração. Em razão do significado particular que os direitos econômicos, sociais e culturais têm, conforme listados dos artigos 22 até o 27, (particularmente o direito à segurança social) reconhece-se como desejável tê-los implementados tanto por meio de esforços materiais nacionais quanto por intermédio de cooperação internacional, considerando os sistemas econômicos e sociais e os recursos de cada Estado ${ }^{83}$. (gn)

\footnotetext{
${ }^{83}$ Os redatores consideraram a filosofia da declaração deles como sendo neutra, pois eles não acharam que tomaram partido no combate entre abordagens liberal e conservadoras para as políticas públicas ou entre proponentes de economias livres ou planificadas.

Mas qualquer ideologia que não respeitasse os direitos humanos e as liberdades fundamentais e que não se esforçasse para manter a boa vontade internacional e que não combatesse o ódio aos grupos raciais e religiosos era para eles uma ideologia política não viável.

Os direitos humanos que eles proclamaram eram, para os redatores, um cimento moral que vincula as sociedades crescentemente pluralistas do mundo moderno; eles viam-nos como um terreno comum em que todos os membros da raça humana caminhavam e em que todos eles erigiam suas próprias comunidades e
} 
Enquanto as delegações votaram 5 a 1, com 9 abstenções para ter a cláusula de segurança social incluída, a Terceira Sessão rejeitou esse texto alternativo.

Ao recomendar esse mesmo texto rejeitado ao Terceiro Comitê, Pavlov relembrou que a ideia de um segundo artigo de cobertura tinha sido o de "enfatizar a importância dos direitos econômicos e sociais afirmados na Declaração. Esses novos direitos não tinham aparecido em nenhuma prévia declaração dos direitos do homem; a inclusão deles decorreu dos progressos sociais alcançados nos séculos XIX e XX." Pavlov recebeu o apoio de outras delegações comunistas. (gn)

Jiri Nosek da Theco-eslováquia pensou que as objeções padrões aos deveres dos Estados eram "menos justificadas" no caso dos novos direitos do que elas tinham sido, quando levantadas durante a adoção de artigos prévios. Um instrumento puramente legal e formal seria suficiente para garantir a implementação dos direitos proclamados nos artigos precedentes, mas de modo a tornar o direito à segurança social efetivo, os novos direitos tinham de ter uma base apropriada - uma base econômica sem a qual não poderia ter um seguro social propriamente". (gn)

Demtchenko da República da Ucrânia também destacou a importância do artigo 22 como "um elo entre" a seção precedente de direitos políticos e os direitos econômicos, sociais que os seguiam. Ambas delegações falaram em favor da proposta normativa patrocinada pela União Soviética, mas esses comentários podem ser lidos como forma de apoio ao artigo 22, se lido de um modo benigno.

Há duas diferenças evidentes entre o texto patrocinado pela URSS e o produto final. O artigo 22 da DUDH1948 é mais indireto sobre os deveres dos Estados e afirma que a realização é exclusiva para os novos direitos, ignorando todos os outros direitos que também necessitam ser implementados. Cada um desses dois pontos foi objeto de críticas. Os opositores com perspectiva maligna não gostaram das referências explícitas aos deveres dos Estados, pois eles não queriam estar muito diretamente vinculados aos deveres correlativos de fornecerem assistência material. Os opositores com perspectiva benigna deram como razão pelo não apoio à proposta soviética o fato de eles preferirem um foco mais restrito do artigo 22.(gn)

nações, grandes e pequenas. in MORSINK, Johannes, The Universal Declaration of Human Rights : Origins , Drafting and Intent, University of Pennsylvania Press, 1999. p327 
Cassin disse que a presença do artigo 22 era uma indicação de que

os direitos sociais tinham características diferentes de quaisquer direitos descritos em declarações do homem precedentes. Tudo o que os direitos novos tinham em comum era o fato de que tanto o esforço nacional quanto a cooperação internacional serem necessárias para a realização deles. (gn)

As delegações da América Latina tinham bastante simpatias pela posição soviética, pois compartilhavam da opinião de que se alguma ponderação dos direitos tivesse de ser feita, os novos direitos possivelmente seriam mais importantes por causa de eles necessitarem de codificações adicionais; no entanto, essa perspectiva levou o bloco latino-americano a dar suporte ao artigo 22 ao invés do texto russo.

Pérez Cisneros, o representante de Cuba, disse que

uma afirmação dos direitos sociais era um dos pontos mais importantes na Declaração, por isso, não deveria ser fraca nem vaga.

Santa Cruz do Chile achou que a emenda soviética era "muito longa", porém ele não tinha nenhum desacordo com as ideias ali contidas; em particular, a garantia de direitos econômicos, sociais e culturais pelo Estado e pela sociedade. Uma vez que esses direitos diferiam de todos os outros direitos por requererem uma ação positiva do Estado antes que eles pudessem ser desfrutados, era muito apropriado impor uma obrigação definitiva sobre o Estado".

Watt, o delegado australiano,

destacou a importância especial dos artigos referentes aos direitos sociais, econômicos e culturais... Os direitos mais antigos tinham sido reconhecidos, em teoria, há muito tempo [...] e todos no mundo esperariam encontrá-los incluídos na Declaração. Por essa razão, parecia justificável incluir um artigo introdutório antes da proclamação desses direitos mais novos. $\mathrm{O}$ artigo 22 expunha o real problema, ao destacar a necessidade de cooperação internacional, bem como de ação 
nacional de acordo com o artigo 56 da Carta da $\mathrm{ONU}^{84}$.

Na mesma direção, Conde Carton de Wiart, delegado belga, observou:

todos os delegados estavam de acordo com o desejo de preservar a natureza introdutória do artigo 22. Esse artigo introduzia novas ideias, enquanto os artigos precedentes reviviam ideias expressas na Declaração de Direitos do Homem e dos Cidadãos de 1789 e na Carta de Direitos Americana de 1776.

Basicamente, somente a delegação estadunidense usou a distinção entre direitos velhos e novos de uma perspectiva maligna. Roosevelt explicou que:

um compromisso entre opiniões de certos governos que estavam ansiosos para que o Estado devesse dar reconhecimento especial aos direitos econômicos, sociais e culturais do indivíduo, e a perspectiva de governos, como o dos Estados Unidos, que consideravam que a obrigação do Estado não devesse ser especificada.

Roosevelt opunha-se à "obrigação que recaía sobre o Estado" na proposta soviética e à maneira como a proposta "dava importância especial aos direitos econômicos, sociais e culturais". A Declaração, disse ela,

deveria enunciar direitos do homem, e não as obrigações dos Estados. Além disso, os direitos econômicos, sociais e culturais, apesar da importância, não eram mais importantes do que os direitos políticos. (gn)

Ademais, ela destacou que, para a delegação dela, as frases "por meio de esforço nacional e cooperação internacional" e "de acordo com a organização e os recursos de cada Estado" eram as chaves do artigo.(gn)

${ }^{84}$ artigo 56, Carta da Onu: Para a realização dos propósitos enumerados no artigo 55, todos os membros da Organização se comprometem a agir em cooperação com esta, em conjunto ou separadamente. 
Depois desse intercâmbio de opiniões, o texto soviético foi novamente rejeitado. Desta vez, por 27 votos contrários a 8 favoráveis, com 8 abstenções, o que deixou no seu lugar o artigo 22.

O que precisa ser realçado é que a criação do artigo 22 era o resultado de um compromisso entre aquelas delegações que queriam os deveres do Estado para combater o desemprego mencionado no mesmo artigo em que o direito a essa proteção era mencionado e aquelas que não estavam seguras da necessidade de referências estatais e deveres. O compromisso foi que ambos direitos e o dever correlativo deveriam ser mencionados, mas não no mesmo artigo. $\mathrm{O}$ direito à proteção contra o desemprego foi inserido no primeiro parágrafo do artigo 23, e os deveres dos Estados foi constituído pela frase "esforço nacional e cooperação internacional" do artigo 22 , o que veio a servir como introdução para todos os direitos econômicos, sociais e culturais na Declaração. (gn)

Nesta discussão, em particular, Morsink ${ }^{85}$ explica que:

os representantes das delegações dos Estados-nacionais observaram que a luta contra o desemprego não poderia ser simplesmente o dever específico de cada país em separado, mas esse combate requeria cooperação internacional. Indo um passo além, eles notaram que essa cooperação também é necessária para implementar todos os outros direitos econômicos, sociais e culturais da Declaração.

Dessa atenção tardia e generalizada dos autores da Declaração na Terceira Sessão, originou-se o artigo 22:

Toda pessoa, como membro da sociedade, tem direito à segurança social e à realização, pelo esforço nacional, pela cooperação internacional e de acordo com a organização e recursos de cada Estado, dos direitos econômicos, sociais e culturais indispensáveis à sua dignidade e ao livre desenvolvimento de sua personalidade.

${ }^{85}$ MORSINK, Johannes, The Universal Declaration of Human Rights : Origins, Drafting and Intent, University of Pennsylvania Press, 1999. p.84 e sgts. 
Morsink chama a atenção para o fato de:

Ao listar esse artigo (22) com o que me referi como os "direitos internacionais especiais" da Declaração, alertanos para o fato de que, em razão de o artigo 22 acarretar todos os direitos sociais, econômicos e culturais, todos esses direitos mais específicos são internacionais também no sentido de que a realização deles, com frequência, demanda um tipo de "cooperação internacional" 86 . (gn)

Conforme afirma o próprio Morsink $^{87}$, e concordamos em gênero, número e grau com seu raciocínio e experiência:

Esses direitos humanos internacionais especiais (possibilitantes de cooperação internacional), são, portanto, verdadeiros casos empíricos de quaisquer listas de direitos humanos, pois, na condição deles, o problema $^{88}$ da soberania não pode mais ser escondido atrás do véu do direito positivo nacional. (gn)

${ }^{86}$ Contextualiza Morsink sobre aquilo que ele denominou de "direitos humanos internacionais especiais":a maioria das delegações teve pouca dificuldade em votar para muitos direitos na Declaração, pois, com muita frequência, as próprias constituições nacionais também continham o direito específico a ser votado como proposição normativa. Tudo que era requisitado era fazer uma mudança da escala nacional para a internacional. E quando os delegados consideraram como esses direitos poderiam ser implementados, tudo o que eles tinham de fazer era pensar em como aumentar a vigilância na jurisdição de cada Estado-nação. Os governos soberanos, desse momento em diante, fariam de acordo com o guarda-chuva internacional o que eles já estavam fazendo de acordo com suas jurisdições domésticas.

No caso de alguns dos direitos da DUDH1948, essa mudança de perspectiva não era tão fácil, porque a maioria das constituições domésticas dos Estados-membros não continha nenhum daqueles direitos que denominei "direitos humanos internacionais especiais". As constituições nacionais não se dirigem às audiências mundiais e, portanto, em regra, não dispõem de direitos que requerem mais de uma nação para implementá-los, como o direito de locomoção entre os países(artigo 13), o direito ao asilo (artigo 14), e o direito à nacionalidade (artigo 15) Para as pessoas gozarem desses direitos, vários países têm de cooperar e, portanto, ceder um pedaço da soberania deles. O mesmo é verdade para os artigos 22, 28, 29(3), e 30, que também requerem cooperação internacional.(gn) in MORSINK, Johannes, The Universal Declaration of Human Rights : Origins, Drafting and Intent, University of Pennsylvania Press, 1999. p.84

87 MORSINK, Johannes, The Universal Declaration of Human Rights : Origins , Drafting and Intent, University of Pennsylvania Press, 1999. p73

${ }^{88}$ Empregamos a palavra problema em seu sentido original, como algo posto como objeto de análise, implicando a possibilidade de alternativas. 
Conforme Cassin disse no Terceiro Comitê de discussões sobre asilo:

no caso dos artigos estudados até agora, a sociedade nacional em que o indivíduo vivia era demandada para garantir os direitos em questão. O direito ao asilo, por sua vez, era uma concepção de características essencialmente internacionais: era, portanto, necessário especificar quem poderia garantir o gozo desse direito. (grifos nossos)

Aplicamos a mesma observação para todos os direitos ou artigos discutidos nesta dissertação.

Relata-nos Morsink ${ }^{89}$ que, durante as discussões acerca do artigo 22, um bom número de representantes expressaram a opinião de que não havia nada especial com respeito aos direitos econômicos, sociais e culturais. Esses autores acreditavam que a cooperação internacional era, igualmente, necessária para a realização de todos os outros direitos da DUDH1948. Essas delegações, portanto, propuseram um artigo 28 com um escopo ainda mais genérico:

Toda pessoa tem direito a uma ordem social e internacional em que os direitos e as liberdades estabelecidos na presente Declaração possam ser plenamente realizados.

Todos os lados nesta disputa ficaram satisfeitos, quando ambos artigos (22 -sobre a realização dos novos direitos - e 28 -sobre a realização de todos os direitos) foram adotados. As discussões sobre esses dois artigos estão intimamente ligadas à controvérsia de existir dois tipos de direitos na DUDH1948 ${ }^{90}$, os direitos "reais" políticos e

${ }^{89}$ MORSINK, Johannes, The Universal Declaration of Human Rights : Origins, Drafting and Intent, University of Pennsylvania Press, 1999. p.84 e sgts

${ }^{90}$ Essa controvérsia, apesar de ter sido plenamente dirimida no processo decisório da Comissão de Direitos Humanos (1947-1948), somente foi sanada no âmbito da diplomacia parlamentar, quando da Conferência Mundial de Direitos Humanos de 1993, em Viena, Áustria, quando essa Conferência ofereceu uma oportunidade singular para uma análise abrangente do sistema internacional dos direitos humanos e dos mecanismos de proteção dos direitos humanos.

Na Declaração e Programa de Ação de Viena, os representantes dos Estados-nações reconheceram e afirmaram que todos os direitos humanos têm origem na dignidade e no valor inerente à pessoa humana, $\mathrm{e}$ que esta é o sujeito central dos direitos humanos e ressaltaram que a DUDH1948 constitui uma meta comum para todos os povos e todas as nações, bem como é fonte de inspiração e tem sido utilizada Nações Unidas na definição de normas previstas nos instrumentos internacionais de direitos humanos existentes, 
civis e os "utópicos" econômicos, sociais e culturais.

Alerta Morsink que:

uma leitura apressada da Declaração pode sugerir que os autores não pensavam que esses "novos" direitos do século XIX tinham o mesmo status que os mais "velhos"e mais estabelecidos direitos civis e políticos que vindos do século XVIII.

$\mathrm{O}$ argumento dos críticos seria que, no artigo 22 , os redatores fizeram reservas e qualificações as quais eles não tinham feito, quando eles adotaram os direitos antigos do século XVIII que estão localizados na primeira metade da Declaração. As frases do artigo 22, "como membros da sociedade", "pelo esforço nacional" e "pela cooperação internacional", e "de acordo com a organização e os recursos de cada Estado", são todas consideradas como características de um status jurídico mais baixo, pois os redatores fazem qualificações que não fizeram com os direitos listados previamente.

Mesmo que os direitos listados após o artigo 22 tenham entrado desde o início por meio da conexão latino-americana de Humphrey, essas qualificações marcam-nos como menos absolutos e dãolhes um status de segunda classe dentro da Declaração. E assim o argumento dos críticos pode desenvolver-se, mas essa é uma leitura muito rápida do documento.

Os autores estavam cientes das diferenças entre as duas gerações de direitos; a maioria deles opinava que essa diferença estava confinada dentro da igualdade mais fundamental e da unidade orgânica de todos os direitos no documento deles.

particularmente no Pacto Internacional dos Direitos Civis e Políticos e no Pacto Internacional de Direitos Econômicos, Sociais e Culturais.

Além disso, os diplomatas lembraram também a determinação contida no Preâmbulo da Carta das Nações Unidas de preservar as gerações futuras do flagelo da guerra, de estabelecer condições sob as quais a justiça e o respeito às obrigações emanadas de tratados e outras fontes do direito internacional possam ser mantidos, de promover o progresso social e o melhor padrão de vida dentro de um conceito mais amplo de liberdade, de praticar a tolerância e a boa vizinhança e de empregar mecanismos internacionais para promover os avanços econômicos e sociais em benefícios de todos os povos. 


\subsection{3 - A NOMOGÊNESE DO DIREITO À ALIMENTAÇÃO NO ARTIGO $25^{91}$ DA DECLARAÇÃO UNIVERSAL DE DIREITOS HUMANOS}

Se quaisquer direitos humanos existem de verdade, pareceria que os direitos à alimentação, ao vestuário, à moradia e à atenção médica teriam de estar entre eles. Henry Shue denominou-os "direitos básicos", porque, como ele coloca, "o gozo deles é essencial ao gozo de todos os outros direitos". É difícil ver como, por exemplo, alguém pode gozar o direito à liberdade de expressão, se a pessoa for sem-teto, não ter comido por dias, está procurando por um casaco no lixo e não tem recebido tratamento para diabetes avançada, uma vez que todas essas razões estão além do controle dela. Logo, é importante destacar esses direitos básicos, explicar como eles entraram na Declaração, e porque eles se mantiveram nela. (gn)

$$
\text { Como explica Morsink }{ }^{92} \text { : }
$$

A maioria dos artigos são como cebolas com camadas de redação negociadas em torno de uma ideia original. No caso do artigo 25 , o cerne original é a segunda metade do primeiro parágrafo que afirma o direito de todos à "segurança no caso de desemprego, doença, invalidez, viuvez, envelhecimento e outra falta de subsistência em circunstâncias além do controle da pessoa".

A esse núcleo, foi adicionado o segundo parágrafo, que demanda especial atenção à "maternidade e à infância", e a primeira parte do primeiro parágrafo, que dá a todos "o direito a um padrão de vida adequado à saúde e ao bem-estar de si e de sua família, incluindo alimentação, vestuário, moradia, cuidados médicos e os serviços sociais necessários".

\footnotetext{
${ }^{91}$ DUDH1948, artigo 25:

1. Toda pessoa tem direito a um padrão de vida capaz de assegurar a si e a sua família saúde e bem-estar, inclusive alimentação, vestuário, habitação, cuidados médicos e os serviços sociais indispensáveis, o direito à segurança, em caso de desemprego, doença, invalidez, viuvez, velhice ou outros casos de perda dos meios de subsistência em circunstâncias fora de seu controle.

2. A maternidade e a infância têm direito a cuidados especiais. Todas as crianças, nascidas dentro ou fora do matrimônio, gozarão da mesma proteção social.

${ }^{22}$ MORSINK, Johannes, The Universal Declaration of Human Rights : Origins, Drafting and Intent, University of Pennsylvania Press, 1999.p.191 e sgts
} 
A lista de direitos aos cuidados médicos é o (sic!) único lugar na Declaração em diz explicitamente que todos têm os direitos básicos à comida, ao vestuário, à moradia e ao atendimento médico. Por causa de sua fundamentalidade, esses direitos são "as razoáveis demandas mínimas em relação ao resto da humanidade".(gn)

Três desses direitos entraram na DUDH1948 com base na tradição socialista latino-americana, novamente com Humphrey servindo de elo. O quarto direito (ao vestuário) foi primeiro adicionado pela delegação filipina. Esses quatro direitos fundamentais (à alimentação, ao vestuário, à habitação e a cuidados médicos) quase foram perdidos em razão do desejo da Comissão por brevidade, mas, por causa da insistência da delegação soviética, os direitos à habitação e a cuidados médicos foram resguardados e, por causa da insistência similar da delegação chinesa, os direitos à alimentação e ao vestuário foram também salvos. (gn)

Na proposta normativa organizada por Humphrey, o direito a cuidados médicos estava em um artigo separado dos direitos à alimentação e à habitação. Países, cujas constituições ou afirmavam, explicitamente, o direito a cuidados médicos ou que tinham esse direito disposto em cláusulas sobre os deveres do governo, incluíam Bolívia, Brasil, República Bielorrussa, Chile, China, Cuba, Honduras, Panamá, Paraguai, Peru, União Soviética, Uruguai e Iugoslávia. Os países do Atlântico Norte notavelmente não tinham em suas constituições o direito a cuidados médicos e outros direitos básicos em suas constituições. (gn)

Morsink explica que:

$\mathrm{Eu}$ considerei que a relutância inicial dessas delegações em reconhecer o completo status aos "novos direitos" em razão, em parte, das lacunas em suas constituições (apresso-me em excluir as antigas colônias dessa acusação. Enquanto o delegado britânico argumentava que "essa seção inteira que estabelecia os direitos econômicos e sociais devessem ser consideradas pelas agências especializadas, a delegação indiana submeteu uma proposta declarando que "todo ser humano tem o direito à saúde". 
Com relação aos direitos à alimentação e à habitação, Humphrey tinha consigo uma declaração clara redigida pelo Instituto Legal Americano que foi submetida pela delegação panamenha:

Todos têm o direito à alimentação e à habitação adequadas.

Humphrey tomou a emprestado e adicionou-lhe uma segunda frase que ele coletou da proposta cubana. Isso resultou no H42: "Todos têm o direito à boa alimentação e à habitação e a viver em redondezas que são agradáveis e saudáveis". Desde que H35 tinha falado também do direito a 'cuidados médicos', havia uma sobreposição entre ele e o H42. Diferentemente do caso do H35, no H42, Humphrey não incluiu uma referência aos deveres correlativos dos Estados.

Enquanto nenhum desses dois direitos estavam incluídos nas constituições dos países do Atlântico Norte, 10 países latino-americanos e a Iugoslávia davam aos seus cidadãos um direito constitucional à habitação barata e limpa. As citações constitucionais formam o pano de fundo para o direito à habitação que encontramos no texto PanamenholInteramericano de onde Humphrey tinha tomado emprestado, mas o direito à alimentação era uma adição nova e exótica!!! (grifos nossos)

Na submissão panamenha do texto Interamericano, cada artigo estava acompanhado por uma lógica explicando a razão da necessidade da inclusão dos direitos na DUDH1948. O comentário do artigo 14, que se tornou H42, evidenciou que "a comida não tinha sido tratada em instrumentos constitucionais até o presente"; porém as Nações Unidas tinham tido uma Conferência sobre Alimentação e Nutrição e 44 nações tinham decidido aumentar os níveis de nutrição para suas populações definitivamente. À luz desse compromisso, talvez a delegação panamenha sentiu que era a hora de codificar esse direito. (gn)

Assim como o direito à habitação, o direito à alimentação poderia - mas não precisaria ser - identificado com um passo em direção as cuidados médicos, que já tinham sido aceitos como um direito básico na tradição latino-americana. O Instituto Legal e a delegação panamenha não puseram o ônus da implementação dos direitos à alimentação e da habitação totalmente sobre o Estado ou o governo. A proposta deles 
notava que "esse artigo garante ao indivíduo a 'oportunidade de obter' comida e moradia. O Estado não é demandado prover comida ou habitação, ao menos que o indivíduo não possa, de acordo com a condições existentes, obtê-los por seus próprios meios".(gn)

Críticos dos direitos sociais e econômicos na DUDH1948 precisam estar conscientes do fato segundo o qual a introdução do direito à alimentação e à habitação estava acompanhada pela perspectiva de que "pode ser suficiente para o Estado proteger os seus residentes contra comida estragada ou sem qualidade e garantir um contínuo fluxo de comida a preços dentro da sua capacidade". E com "respeito à habitação, pode ser suficiente para o Estado, por meio do exercício de seu poder regulamentador, garantir que moradia adequada esteja disponível com preços dentro da capacidade de pagamento de seus residentes".(gn)

Também, a proposta panamenha reconheceu que a frase "comida adequada e habitação" tinha de ser interpretada em um contexto de culturas e de climas diferentes, e, mesmo então, um indivíduo somente tinha um direito "àquilo que é razoável de acordo com as circunstâncias".

Segundo ponderação de Morsink:

Comentários como esses sugerem que podemos interpretar esses direitos como parte do moderno Estado de bem-estar social, mas somente se os considerarmos em um modo minimalista que torna a real implementação desses direitos muito dependente da iniciativa individual e dos "recursos de cada Estado". Isso não significa que esses direitos. não sejam reais. (gn)

A real implementação dos DESC depende muito da iniciativa individual e dos 'recursos de cada Estado'. Isso não significa que esses direitos sejam menos reais. Significa, simplesmente, que moradia adequada na Noruega é muito diferente de países tropicais e que alimentação adequada depende da onde se planta. 
Uma coisa é afirmar que os direitos à alimentação, ao vestuário, à habitação e aos cuidados médicos em um nível moral abstrato, e um assunto muito diferente implementar aqueles direitos em níveis doméstico e local. Não houve objeções por Humphrey ter emprestado os "direitos à alimentação e à moradia" da proposta panamenha. Os outros autores aceitaram o raciocínio acima explicado. (gn)

Notando a sobreposição entre H35 e H42, Cassin aglutinou-os em um artigo e adicionou uma segunda sentença :

"Todos têm o direito às melhores condições de saúde possíveis e à assistência para preservá-los. A comunidade deverá promover as melhores condições de higiene pública, de habitação e de alimentação".

Segundo análise de Morsink, Cassin pôs um pouco de água no vinho dos direitos, pois, ao invés de todo indivíduo ter o direito aos cuidados médicos, ele tem o direito ao muito mais vago 'melhores condições de saúde', bem como a comunidade deve 'promover' certas políticas públicas. Esse afastamento dos direitos básicos encaixa-se com a relutância inicial de Cassin em aceitar que esses novos direitos fossem completamente reconhecidos como tais.

Tão avançado quanto no Grupo de Trabalho da Segunda Sessão, Cassin

enfatizava que as obrigações dos governos não poderiam ser as mesmas em relação a todos os direitos, por exemplo, com relação ao direito à vida e ao direito à nacionalidade, ou ao direito de pertencer aos sindicatos, e o direito a condições higiênicas de moradias e ao direito à saúde (SR.1/p.4).

Pouco antes da proposta normativa reescrita por Cassin ser lida para a relatório oficial da Primeira Sessão de Rascunho, Eleanor Roosevelt, presidenta da CDH, "afirmou que os EUA apoiavam a substância do artigo de Cassin sobre cuidados médicos, mas preferia que a redação submetida pelos Estados Unidos, que era uma adaptação do Tratado Constitutivo da Organização Mundial de Saúde" (SR.14/p.8). 
Com modificações pequenas, a proposta americana foi adotada pelo Comitê Elaborador, resultando no fato de a Segunda Sessão da Comissão ter começado com essa versão do direito aos cuidados médicos:

Todos, sem distinções de condições econômicas e sociais, têm o direito ao padrão de saúde atingível mais alto. A responsabilidade do Estado e da Comunidade pela saúde e pela segurança das pessoas pode ser desenvolvida somente por intermédio de 'medidas adequadas de saúde e sociais.

Os direitos à "alimentação e à habitação adequadas" foram totalmente retirados e a proposta de Humphrey de 'direito aos cuidados médicos' tinha sido mudada para o direito ao 'mais alto padrão alcançável', o que não é a mesma coisa que ter um direto aos cuidados médicos explícito. (gn)

O pêndulo oscilou novamente para os direitos básicos no Grupo de Trabalho da Segunda Sessão da Comissão. Bogomolov, o delegado soviético, opôs-se ao vago palavreado do artigo e propôs que "o direito do indivíduo à correta proteção de sua saúde devesse ser expressamente formulado [...] e tornado barato e acessível". A presidenta Roosevelt respondeu que "nenhum detalhamento a mais era praticável, uma vez que as diferentes provisões para a proteção da saúde estavam estabelecidos em países diferentes".

Retornando à sua conexão precedente de alimentação, de habitação e de saúde, Cassin concordou com Bogomolov e propôs:

"Todos têm o direito à proteção de sua saúde, mediante boa moradia, alimentação adequada e cuidados médicos". (gn)

Isso deixou de fora a proibição discriminatória da OMS, o que levou Bogomolov a salientar que os direito aos cuidados médicos dizia especial respeito " à assistência médica das classes mais pobres", o que August Istendael da Federação Internacional dos Sindicatos Cristãos concordou. 
Carlos Rômulo das Filipinas fundiu todas essas sugestões em uma única sentença:

"Todos sem distinção de condições econômicas ou sociais têm o direito à preservação de sua saúde por intermédio de alimentação, de vestuário, de habitação e cuidados médicos adequados".

Aqui, temos a primeira referência ao direito ao vestuário, que até então não fazia parte do texto. Houve um precedente para ele na submissão cubana, que listava o direito de uma pessoa a condições de vida higiênicas e de vestimenta apropriadas para o clima em que se vive".

O Grupo de Trabalho adotou essa proposta filipina por 4 votos a 0 com 2 abstenções. Enquanto esses três direitos (à alimentação, ao vestuário e à habitação) estavam identificados como meios para a finalidade do cuidado médico, o texto filipino representou um retorno à linguagem dos direitos básicos que Humphrey tinha usado.(gn)

Na plenária da Segunda Sessão, Charles Dukeston, representante do Reino Unido, propôs trocar as palavras "por intermédio de alimentos, vestuário, habitação e cuidados médicos adequados" pelas palavras "por meio do padrão mais alto de alimentação, vestuário e cuidados médicos que os recursos do Estado ou da comunidade podem prover". Dukeston fez essa proposta, porque ele achou "ser um erro proclamar direitos sem mencionar os deveres dos beneficiários", uma conexão estrita que ele não insistiu no caso dos direitos civis e políticos que já tinham sido adotados. Ele sentia que, na terminologia do Grupo de Trabalho, faltava a provisão sobre os recursos, o que poderia "levar a incompreensão com respeito à parte que cabia ao Estado" na implementação desses novos direitos. (gn)

A emenda britânica passou com uma votação de 8 a 2 com 5 abstenções, o que levou ao seguinte texto do que era, então, o artigo 33: (gn)

Todos, sem distinção de condições econômicas e sociais, têm o direito à preservação de sua saúde mediante o mais alto padrão de alimentação, de vestuário, de habitação e de cuidados médicos que os recursos do Estado ou da comunidade 
possam prover. A responsabilidade do Estado e da comunidade para com a saúde e a segurança de seu povo podem ser realizadas somente por provisão adequada de serviços sociais e de saúde.

Esse texto põe os direitos "à alimentação, ao vestuário e aos cuidados médicos" de volta para o domínio das políticas públicas, pois o inicial "direito à preservação de sua saúde" estava limitado pelos recursos do Estado ou da comunidade. Essa restrição torna esses direitos relativos à capacidade de provisão do país ou da comunidade em que alguém vive. Nada foi dito a respeito da necessidade de cooperação internacional. Se o padrão mais alto alcançável em um certo período e lugar não for suficiente para alimentar a população, então, presumivelmente, aqueles famintos não têm o direito humano à alimentação, mesmo se houver abundância em outro lugar.(grifos nossos)

Em razão da Terceira Sessão da Comissão estar muito ávida para manter as coisas curtas e ao ponto, ela decidiu fundir o artigo sobre os direitos aos cuidados médicos que estavam sendo discutidos (artigo 33 da Segunda Sessão) com outro artigo ainda mais longo (então 34) sobre direitos à segurança social e à proteção da maternidade e das crianças. Essa fusão tornou-se nosso artigo 25. (gn)

O mais curto e, portanto, mais popular dessas propostas aglutinadas foi a indiano-britânica. Ela simplesmente afirmava:

Todos têm o direito a um padrão de vida adequado para a saúde e o bem-estar, incluindo segurança no caso de desemprego, invalidez, velhice ou falta de subsistência em circunstâncias além de seu controle. (E/CN.4/99)

Retirados foram os direitos explícitos à alimentação, ao vestuário e à habitação. Roosevelt disse que a delegação dela "favorecia" esse texto, mas sugeriu que o direito aos "serviços sociais necessários" fosse adicionado à lista de intitulamentos. Ela fez a sugestão, disse ela, "em razão de tornar claro que o termo 'segurança social' abrangesse o direito aos serviços assim como à proteção econômica". Ela foi apoiada nisso pelas delegações da Austrália e do Líbano e, posteriormente, por Metha, a delegada indiana, que demandava a reinserção de um parágrafo sobre infância e maternidade. (gn) 
Pavlov, delegado da União Soviética, rapidamente notou que o texto curto indiano-britânico "omitiu todas as referências" ao "direito do homem aos cuidados médicos e à habitação", ambos, ele argumentou, eram melhores lidados na União Soviética do que nos EUA.

Um subcomitê de rascunho, designado pelos delegados da França, da Índia e do Reino Unido, escolheu não incluir declarações explícitas sobre os direitos aos cuidados médicos, habitação, alimentação e vestuário, apesar de ele ter incorporado a sugestão de Roosevelt para que a lista incluísse o direito aos "serviços sociais". Pavlov novamente sentiu-se compelido a mencionar que "todas as referências à habitação e à assistência médica tinham sido suprimidos". A presidenta Roosevelt respondeu que esses tipos de direito estavam cobertos pelos direitos à "segurança social" e "um padrão de vida". Geoffrey Wilson, delegado britânico, sugeriu que "aqueles serviços estavam incluídos nos termos mais abrangentes usados no novo texto".(gn)

\section{O assunto veio à baila na Septuagésima Primeira Reunião da} Terceira Sessão.(gn) Naquele ponto, a Comissão aceitou a seguinte proposta da OIT:

Todos têm o direito a um padrão de vida e aos serviços sociais adequados para a saúde e o bem-estar de si e de sua família (e à segurança social) incluindo a proteção em casos de desemprego, doença, invalidez, velhice ou outra falta de subsistência em circunstâncias além do seu controle (SR.71/p.2).

A presidenta assinalou que uma votação em separado tinha de ser feita na frase entre parênteses. Ela também comunicou o fato de que a delegação da União Soviética tinha requisitado que a frase "segurança social, habitação e cuidados médicos" fosse incluída no texto da OIT. O requerimento comunista para a inclusão dos direitos à "habitação e cuidados médicos" falhou em restaurar os direitos à alimentação e ao vestuário que também foram eliminados. Por essa razão, a delegação chinesa propôs que todos os quatro direitos suprimidos fossem restabelecidos. (gn)

Rudolf Metall, o representante da OIT, "apoiou a sugestão do representante chinês de que as palavras "incluindo habitação e cuidados médicos, alimento e vestuário' devessem ser inseridas depois das palavras serviços sociais". 
Inicialmente, Roosevelt também pensou que a frase "alimentos, vestuário, habitação e cuidados médicos" devesse estar incluída no artigo, mas depois da argumentação do Wilson segundo a qual a emenda soviética não adicionava realmente nada de necessário à proposta da OIT à mesa, ela deu um passo para trás. Wilson disse que:

os cuidados médicos estavam cobertos duas vezes; a primeira pelas palavras 'padrão de vida' e novamente pela 'saúde e bem-estar`.Tanto habitação quanto alimentação e vestuário estavam cobertos pelo ' bem-estar de si e de sua família'.

A presidenta da CDH, então, cortou sua concessão em dois, dizendo que "ela apoiaria a inclusão de 'cuidados médicos e habitação' pelo bem da unanimidade, porém não aceitaria os direitos à alimentação e ao vestuário.(gn)

Alexei Pavlov defendeu suas propostas de forma vigorosa e bem estruturada, que incluíam afirmações explícitas dos direitos aos cuidados médicos e à habitação, mas, como dissemos, não em relação aos à alimentação e ao vestuário. Como ele tinha feito na reunião precedente, ele se engajou numa análise comparativa das políticas de habitação e cuidados médicos em seu país e nos EUA. Ele sentia que o "direito de um trabalhador à habitação deveria ser afirmado em termos concretos. Não havia igualdade de habitação em muitos países". (gn)

Roosevelt tinha se oposto à proposta soviética, porque "todo país tinha suas próprias concepções do que constituía habitação merecedora da dignidade de um ser humano". A frase e o direito seriam de implementação muito difícil. Pavlov concordou que "era impossível usar a mesma forma de palavras para todos", mas mencionou aos colegas um "memorando do presidente dos Estados Unidos ao Congresso, que tratava com o problema de milhões de pessoas jovens forçadas a viverem em favelas". Ele achava que o conceito de dignidade humana era "suficientemente evidente" para direcionar e condenar aqueles tipos extremos de condições. "Seres humanos, disse ele, "não deveriam viver como animais; eles não deveriam ser forçados a viver em favelas, barracos ou cavernas. A eles, deveria ser providenciada habitação adequada que não arriscaria a saúde deles ou de suas famílias". (gn) 
A emenda soviética demandando um parágrafo separado a respeito do direito à habitação foi rejeitada por 6 votos a 4, com 3 abstenções.(gn)

Roberto Fontaina, representante do Uruguai, disse que ele sentia que o parágrafo rejeitado "simplesmente era uma injunção para os Estados fornecerem moradias gratuitas"(SR.71/p.12). Pavlov imediatamente "replicou que o contexto e especialmente o último parágrafo de sua emenda claramente mostrava que ela não significava isso" e que "as possibilidades variavam de país a país". O último parágrafo afirmava que "o Estado e a sociedade deverão tomar todos os passos necessários para incluir legislação que garanta que toda pessoa tenha uma real oportunidade de gozar desses direitos".

Depois que os parágrafos separados [direito aos cuidados médicos ] patrocinados pela URSS tinham sido rejeitados, a Comissão estava pronta para votar o primeiro parágrafo da proposta da OIT.

Tendo proposto a reinserção da lista de cuidados médicos, P.C. Chang, o delegado chinês, duas vezes sentiu-se convidado a defender os direitos à alimentação e ao vestuário. Em um dado momento, Wilson do Reino Unido tinha dito que ele não achava "que havia qualquer necessidade para as palavras 'alimentação e vestuário' propostas pela emenda chinesa"(SR.71/p.11). Quando chegou a hora de votar, Wilson declarou-se "em favor de uma votação separada sobre se uma referência especial deveria ser feita em relação à alimentação e ao vestuário". (gn)

Chang respondeu que:

ele não via que possível objeção poderia haver em relação àquela frase, quando milhões de pessoas ao redor do mundo estavam privadas de comida e de vestuário".(gn)

Esses dois itens são primordiais na dieta confuciana da benevolência segundo a qual os bons reis servem seu povo ${ }^{93}$.

93 Com respeito à dieta confuciana da benevolência e da virtuosidade dos diplomatas envolvidos tanto na redação da Declaração quanto na nomogênese do direito à alimentação, segue um breve histórico-axiológico de uma das 64 leis do I Ching, estudo sobre as circunstâncias e a naturalidade: o Caldeirão.

Segundo Wu Jyh Chern, em sua obra, I-Ching, A Alquimia dos Números, na China, a transmissão tradicional dos ensinamentos é protagonizada por duas correntes: Confucionismo e Taoísmo. O Confucionismo é chamado de Ru Jia, a Família da Erudição, e está voltado para a questão da harmonia da vida cotidiana. Ele considera que, para a formação de 
Morsink afirma que:

Se não tivesse sido a intervenção de Chang em sua Septuagésima Primeira Reunião da Terceira Sessão da Comissão de Direitos Humanos, esses direitos [à alimentação e ao vestuário] provavelmente teriam se perdido na DUDH1948. (gn)

caráter de uma pessoa, é necessário que se cumpram seis estudos clássicos: I Ching, Ritos e Cerimônias, Poesia, Literatura, Música e História.

O I Ching é a base. No estudo dos Ritos e Cerimônias, aprende-se a arte da convivência social, i.e., o respeito às divindades, à natureza e às pessoas; na Poesia, aprende-se a sutileza de transcender a linguagem verbal; por intermédio da Literatura, desenvolve-se a aptidão para o entendimento das sagradas leituras da Antiguidade; com o estudo da Música, aperfeiçoa-se o diálogo entre os sentimentos dos seres e a natureza; e pelo estudo da História, compreende-se o passado, para enxergar no presente a projeção do futuro.

O Taoísmo preocupa-se com os mistérios do Universo e é chamado de Dao Jia, a Família do Caminho. Fundamenta-se nas Três Obras do Mistério(San Xuan): I Ching como 'Raiz', Tao Te Ching como 'Ramo' e Nan Hua Ching como 'Flor' do misticismo chinês.

Conclui-se que o I Ching, tanto para o Confucionismo quanto para o Taoísmo, é o primeiro e mais importante de todos os estudos. Ele nos descerra os segredos das duas tradições.

Caldeirão é um hexagrama inspirado num caldeirão chinês - que tem algumas características bem específicas - O caldeirão chinês bem tradicional é caldeirão feito de bronze - para fazer cozimento - , tem uma conformação com bojo, alças e argolas. Ele está apoiado sobre três pés - Estas alças eram usadas para carregar o caldeirão, quando a comida ficava pronta.

Pegavam as alças e carregavam o caldeirão de um lado para outro.

O caldeirão originalmente é um instrumento feito para cozinhar - preparar o alimento é uma das coisas mais nobres que a gente faz porque sem o alimento a gente morre.

O caldeirão passou a ter um outro sentido simbólico ao longo do tempo. Um primeiro sentido é de prosperidade, porque ele representa o próprio alimento, mas também de transformação, na verdade, ele está relacionado com transformação. Não é qualquer tipo de transformação, é a transformação que direciona para o refinamento. É uma transformação para elevar a qualidade, e quando a gente cozinha faz isso. Exemplo, pega um alimento que é duro, fica macio, pega um alimento que era tóxico e mediante o cozimento, elimina-se as toxinas e transforma aquele alimento em algo nutritivo. Algo que tem uma qualidade inferior, e depois do cozimento passa a ter uma qualidade superior. Por isso, o Caldeirão representa a transformação por meio de um refinamento.

Ao longo do tempo o caldeirão passou a ser utilizado como símbolo de poder - tanto que antigamente, quando mudava a Dinastia na China, mudava-se a Dinastia e, com isso, mudava-se o poder, então, a nova Dinastia tinha de promulgar novas Leis. Os princípios do novo governo como eram divulgados? Colocavam as Leis em relevo no bojo do caldeirão. Esse caldeirão era colocado na frente do palácio, na área pública para que todos pudessem conhecer quais eram os princípios e os caminhos propostos por aquele Governo, para trazer à nação: prosperidade que é o alimento, e a transformação. Como era que aquele Governo propunha fazer para que o povo pudesse crescer e desenvolver-se - tornar-se mais culto, elevar-se, transformar-se para cima, para o superior. Então sempre que trocava a Dinastia, trocava o Caldeirão.

Segundo o mestre Wu Jyh Chern, em sua obra, I-Ching, A Alquimia dos Números, o Caldeirão traz a mensagem da transformação e da renovação. O cozimento do alimento dentro do caldeirão representa o processamento que transforma o desconhecido em conhecido. Este hexagrama esclarece a importância de se cultivar o que é virtuoso. Todas as renovações benéficas dependem de um personagem virtuoso, por isso, o hexagrama alerta para o perigo de uma atitude desleal nos momentos de grande transformação. Uma transformação provocada por uma atitude desleal pode resultar em desastre e sofrimento. O hexagrama também fala da importância de se manter firmemente no caminho do equilíbrio, sem perder a esperança de uma renovação favorável. Conhecer profundamente a lei da relação fogo-água no "Caldeirão" é a chave da grande transformação. 
Momentos antes da votação, Fontaina do Uruguai disse que "ele não achava que as palavras 'alimentação e vestuário' eram necessárias, uma vez que a frase 'padrão de vida para a saúde e o bem-estar' era suficientemente clara" (SR.71/p.14).

\begin{abstract}
Chang "discordou que o termo 'padrão de vida' fosse suficientemente preciso. $O$ problema em questão dizia respeito não apenas à quantidade, mas também à qualidade da comida. Ele [...] não entendia o desejo de se evitar os dois principais aspectos de um padrão de vida adequado". (gn)
\end{abstract}

Depois desse debate, foi decidido por 11 votos a 3 incluir as palavras 'alimentação e vestuário'. Toda a emenda chinesa -"alimentação e vestuário, habitação e cuidados médicos" - foi adotada por 12 votos a nenhum, com 2 abstenções. (gn)

Esse foi o fim da Terceira Sessão da Comissão e agora temos a lista inteira de direitos básicos (à alimentação, ao vestuário, à habitação, aos cuidados médicos e aos serviços sociais) que a primeira sentença do artigo 25 diz estar incluso no direito de todos "ao padrão de vida adequado para a saúde e o bem-estar de si e da família".

Um dos efeitos negativos da fusão do direito aos cuidados médicos no artigo sobre segurança social é que o direito de uma pessoa à alimentação, vestuário, habitação, cuidados médicos e serviços sociais foram feitos todos dependentes de um membro da casa ou da família com um ganha-pão, que era ou um empregado ou, como o artigo diz, desempregado "por razões além de seu controle". Essa fusão, com efeito, matou, por muito tempo, a existência independente do direito aos cuidados médicos e outros direitos (alimentação, vestuário e habitação) que são meios para ajudar a pessoa a tornar-se e manter-se em boa saúde. (gn)

Como Pavlov assinalou ao Terceiro Comitê "a assistência médica não era meramente um item em um padrão de vida adequado, mas um direito específico". Em seu desejo por brevidade, a Terceira Sessão fundiu esses direitos no direito que os trabalhadores têm à segurança social para eles e para suas famílias.

No nível do Terceiro Comitê, quatro emendas que admitiam que a fusão da lista de cuidados médicos no artigo de segurança social era um erro foram submetidas. A delegação da Nova Zelândia submeteu uma versão do artigo que tinha como seu único 
sujeito a palavra 'todos' e que deu ao sujeito uma longa lista de direitos que consistia na fusão de duas listas que agora temos no primeiro parágrafo do artigo 25. Newlands da Nova Zelândia defendeu a retirada da referência à família, porque ela se opunha à ideia de que "a própria família [...] gozava do direito aos serviços sociais somente por intermédio do chefe da família". Essa omissão da família era a razão de alguns delegados não gostarem da versão simples da nova zelandesa.

A delegação cubana lidou com ambos problemas de uma vez, mediante proposta de dividir o primeiro parágrafo do artigo 25 em dois; o que, com efeito, deu o direito aos cuidados médicos um status mais próximo daquilo que gozava anteriormente. $\mathrm{O}$ primeiro parágrafo da emenda cubana afirmava o direito de toda pessoa "à saúde e ao bemestar" e o segundo o direito de toda pessoa à "segurança social". Cada um desses parágrafos continha sua própria lista, mas nenhuma continha a frase "adequada... para si e sua família", o que solucionou a "objeção familiar" que Newlands tinha levantado. Nenhuma dessas emendas foi à votação, ambas foram retiradas antes da votação. (gn)

O Terceiro Comitê não gostou da emenda cubana, porque, àquele momento, a frase "segurança social" já ocorria no artigo 22.

A conclusão que Morsinsk apresenta, e concordamos, é a seguinte:

Nós podemos concluir que os direitos cruciais têm um status independente. Vimos que os direitos à alimentação, ao vestuário, à habitação e aos cuidados médicos costumavam estar em um artigo por si mesmos e nós podemos trazer essa informação para o significado do artigo 25 .

Podemos admitir que os trabalhadores ou empregados são uma referência de grupo primária para a palavra "todos", mas essa admissão não nega o fato de que todos os outros também tenham esses direitos. Pelo contrário, a história de independência desses direitos demonstra que os autores acreditavam que todos os têm e que, depois disso, eles (inadvertidamente) assinalaram, com atenção especial, esses direitos no caso dos trabalhadores e empregados. Assim, esses 
direitos são possuídos por todos, e não apenas por trabalhadores e membros de suas famílias.

À leitora e ao leitor que nos seguiram até o fim desta introdução sobre a criação do direito à alimentação, podem considerar peculiar a extensão de algo que, por si, significa breve, introdutório; entretanto, em época de Kali ${ }^{94}$, estudar um dos princípios gerais do direito, reconhecidos pelas nações civilizadas ${ }^{95}$ (art. 38,b, CIJ ) e sua função como fonte do direito ${ }^{96}$ contribui para a realização da paz individual à internacional.

Em razão dessa afirmativa, gostaria de chamar a atenção da leitora e do leitor desta nomogênese do direito à alimentação, para o seguinte excerto $\operatorname{adaptado}^{97}$ do discurso de abertura de Eleanor Roosevelt de uma série de seminários na Universidade de Brandeis, em 17 de dezembro de $1954^{98}$ :

${ }^{94}$ TRAVASSOS, Lubélia. Kali Yuga e a Leis dos ciclos. "A Idade do Kālī Yuga começou quando o Avatāra Krishna abandonou o seu corpo físico, há exactamente 5.000 anos. A duração do ciclo maior do Kālī Yuga é de 432.000 anos, sendo o Kālī, o $4 .^{\circ}$ e o mais denso dos quatro Yugas ou Eras Cósmicas do Calendário Hindu, correspondendo, por analogia, à Idade de Ferro dos Gregos, período no qual os valores morais declinam e a materialidade sobrepuja a espiritualidade.

O termo "KĀLII" (negro) refere-se à Deusa Pārvatī, consorte/atributo de SHIVA, responsável pela morte de tudo o que é vil, grosseiro e decrépito. Segundo o Bhagavata Purāna, esta é uma Era de degradação humana, cultural, social, ambiental e espiritual, por isso é referida como Idade das Trevas, pela maioria da humanidade se encontrar longe da espiritualidade e de Deus "

${ }^{95}$ Artigo 38, b do Estatuto da Corte Internacional (CIJ).

96 Diz Miguel Reale: Outra contribuição que, penso eu, a teoria tridimensional vem trazer refere-se a uma renovada "teoria das fontes do direito", não superada, mas completada pela "teoria dos modelos do direito", os quais se distinguem em modelos jurídicos (de natureza prescritiva, inseparáveis das fontes de que promanam, sendo, assim, de ordem legal, costumeira, jurisprudencial ou negocial) e modelos doutrinários (de natureza hermenêutica, não necessariamente vinculados às fontes).

Desse modo, embora a Hermenêutica Jurídica possa condicionar a aplicação dos modelos jurídicos em função das respectivas fontes geradoras, ela se apresenta de maneira autônoma no plano da doutrina, mesmo porque cabe a esta dizer o que as fontes e os modelos significam. Põe-se, portanto, fim a vexata quaestio sobre se a doutrina é ou não fonte do direito, por ter ela natureza própria de caráter hermenêutico, bem diversa do que acontecia ao tempo em que o saber dos jurisconsultos possuía força vinculante.

Quanto à afirmação de que meu pensamento vacilaria entre uma teoria das fontes formais e uma teoria dos modelos jurídicos permito-me observar que, superado um primeiro momento, em que pensara poder substituir a teoria das fontes pela teoria dos modelos, acabei reconhecendo serem as fontes e os modelos do direito necessariamente complementares, tanto assim que os modelos jurídicos conservam a denominação das fontes das quais promanam.

Trata-se, porém, de pontos secundários de dúvida, porquanto, no que se refere aos pontos nucleares da teoria tridimensional do direito, não poderia pretender hermeneuta mais agudo e mais fiel, levando a termo um estudo marcado pela simpatia, sem a qual, no dizer dos pensadores escoceses do século XVIII, não há possibilidade de interpretação e comunicação autênticas. in REALE, Miguel. Teoria Tridimensional do Direito, situação atual, 5 ed. rev. e aum. - São Paulo: Saraiva, 1994.p.153 e sgts

${ }^{97}$ GUIA DE ESTUDOS 2008 do Concurso de Admissão à Carreira Diplomática, FUNAG,2009.

${ }^{98}$ SARAIVA, José Flávio Sombra. História das relações internacionais contemporâneas : da sociedade internacional do Século XIX à era da globalização, (Sombra organizador) São Paulo, Saraiva, 2008. No 
Ouvem-se pessoas dizendo: "Por que as Nações Unidas não têm feito isso ou aquilo?". A Organização das Nações Unidas funciona tão bem quanto seus membros a fazem funcionar, nem melhor nem pior. Então, a primeira coisa a observar é o tipo de engrenagem que foi concebida e o que ela foi incumbida de fazer.

Neste momento, nós devemos nos concentrar na época em que a Carta foi planejada. A guerra não havia acabado, e o sonho era este: a ideia de estabelecer uma organização, cujo objetivo era manter a paz.

Muitas partes do mundo tinham um conhecimento em primeira mão a respeito da guerra, cujo flagelo chegava à sua soleira. Nós não sabíamos o que era isso: ser invadido ou ser bombardeado.

Nós precisamos usar nossa imaginação, porque realmente devemos captar o que as Nações sentiam naquele momento e o que ainda sentem.

O que aconteceu, evidentemente, foi que jamais se alcançou a paz, e, assim, a ONU tem-se obrigado a enfrentar questões que não estavam em seu ideário no momento de sua fundação. O diálogo, por si próprio, pode ser de grande valor. Deve-se conceber a ONU como uma ponte; a Assembleia Geral, como um lugar onde se constroem pontes entre os povos.

capítulo 6, Dois Gigantes e um condomínio : da guerra fria à coexistência pacífica (1947-1968), Sombra Saraiva escreve a seguinte contextualização: "O curso das duas décadas que vinculam o ano de 1947 ao de 1968, no âmbito das relações internacionais, foi ditado pela supremacia de dois gigantes sobre o mundo. Os Estados Unidos e a União Soviética assenhorearam-se dos espaços e criaram um condomínio de poder que só foi abalado no final da década de 1960 e início da de 1970.

Existiram nuances no sistema condominial de poder. Da relação "quente" da guerra fria (1947-1955) à lógica da coexistência pacífica (1955-1968), as duas superpotências migraram da situação de desconfiança mútua para uma modalidade de convivência tolerável. Da corrida atômica do final dos anos 1940 e início dos anos 1950 às negociações para um sistema de segurança mundial sustentado no equilíbrio das armas nucleares, os dois gigantes evoluíram nas suas percepções acerca da sua capacidade que carregavam", e mais verdade do que nunca, ainda carregam! (grifos nossos) 
Dado que várias razões ligavam a DUDH1948 diretamente às promessas dos direitos humanos que os Estados-membros fizeram na Carta da ONU, podia-se esperar que o parágrafo operativo da DUDH fosse devotado à necessidade de ação legislativa.

Conforme uma interpretação com autoridade das sete referências da Carta aos direitos humanos, poder-se-ia pensar que os redatores teriam proposto a DUDH1948 como um padrão para a legislação e a codificação a ser seguida e implementada por todos os Estados-membros e todas as novas nações que se juntariam à Organização das Nações Unidas. Os redatores não puderam fazer isso tão facilmente, porque eles tinham, formalmente, barrado todas as referências ao Estado do documento deles. A resolução egípcia que os redatores já tinham adotado tinha, formalmente, acordado que a formulação de princípios relativos aos deveres dos Estados fossem incorporados em um instrumento apropriado".(gn)

Os instrumentos apropriados que seguiram foram o Pacto de Direitos Civis e Políticos e o Pacto Internacional de Direitos Econômicos, Sociais e Culturais. Tendo lidado com a questão dos deveres dos Estados nesse modo formal, os redatores não podiam demandar dos mesmos Estados como entidades mais diretamente direcionadas no parágrafo operativo.

Uma solução tinha de ser encontrada. O objetivo da educação dos direitos humanos proveu uma alternativa muito boa. ${ }^{99} \mathrm{O}$ Terceiro Comitê mudou o título do documento (de internacional para universal) com vistas a mudar o foco do documento para longe dos delegados e das nações que redigiram-na para as pessoas comuns, homens, mulheres e crianças para que a Declaração se dirigia primariamente.

São esses homens e mulheres comuns que os redatores tinham em mente quando destacaram a meta educacional da proclamação deles. Depois da frase "todo indivíduo e órgão da sociedade", os autores inseriram a cláusula " tendo essa declaração constantemente na mente". Essa cláusula era parte da submissão francesa que era em si um eco da Declaração Francesa de 1789. Essa declaração histórica tinha também como alvo primário a educação do povo francês para que, daí em diante, eles pudessem julgar se o Estado ou o governo deles desempenhava as funções pelas quais ele foi instituído, que era a de proteger os direitos humanos do povo francês.

${ }^{99}$ MORSINK, Johannes, The Universal Declaration of Human Rights : Origins, Drafting and Intent, University of Pennsylvania Press, 1999. ISBN 08122-3474-X (cloth).p.320 
A DUDH1948 pode servir somente como um padrão de cumprimento nas áreas de implementação e de gozo dos direitos listados. O documento visava a ser usado como um texto educativo para dizer às pessoas sobre os direitos inerentes que elas já têm. As pessoas podem medir o gozo dos direitos humanos em relação a esse padrão e ver aonde elas estão sendo reprimidas ou de que maneira a dignidade delas está sendo violada.O padrão com autoridade, na medida em que a DUDH1948 abrange, ajudará as pessoas a fazerem uma reclamação às autoridades, mesmo contra seus próprios governos. Contra esse padrão, o progresso de "todos os povos e de todas as nações" pode e deve ser medido.(gn)

Os versos seguintes capturam o dilema que confronta uma multidão de Afro-Jamaicanos e, seguramente, os povos do mundo em desenvolvimento globalmente. Parece ser nunca o suficiente. Parece nunca haver um fim ao sofrimento. De fato, a pressão e a tribulação parecem escalar na medida em que o mundo adentra a era técnico-científicainformacional. Mais uma vez, Bob Marley usou a imagem do dia a dia dos jamaicanos para representar um problema sensível e de longo alcance. 


\section{Them Belly Full (But We Hungry) ${ }^{100}$}

Them belly full but we hungry

\section{A hungry mob is an angry mob}

A rain a fall but the dirt it tough

A pot a cook but the food no 'nough

You're gonna dance to jah music, dance,

We're gonna dance to jah music, dance,

Forget your troubles and dance,

Forget your sorrows and dance,

Forget your sickness and dance,

Forget your weakness and dance

Cost of livin' gets so high

Rich and poor they start to cry

Now the weak must get strong

They say oh, what a tribulation

Them belly full but we hungry

\section{A hungry mob is an angry mob}

A rain a fall but the dirt it tough

A pot a cook but you no 'nough

${ }^{100}$ MARLEY, Bob, The Wailers. Natty Dread, 1974. Considerada uma transição importante na discografia de Bob Marley, Natty Dread foi o primeiro álbum lançado como Bob Marley \& the Wailers. Em 2003, o álbum foi classificado em 181 na lista dos 500 melhores álbuns de todos os tempos da revista Rolling Stone.

Them Belly Full é o único som do álbum que contém um provérbio ( Uma multidão faminta é uma multidão raivosa) que proporciona um excelente exemplo de como os provérbios transcendem o texto escrito. Them Belly Full constrasta a condição social dos que têm em relação daqueles que não têm, mas, mais do que isso, a música oferece uma receita para se lidar com as realidades de pobreza e de opressão, que transcende os males físicos e psíquicos causados por aquelas condições sociais : "We're gonna dance to Jah music, dance/ Forget your troubles and dance".

Essa música ocorre em um contexto de composições e de álbuns ativistas, como "Rebel Music, "So Jah Seh", "Revolution" e "Natty Dread", os quais continuam a expor a filosofia Rasta e criticam os graves suplícios do povo negro em relação ao poder do sistema branco, oferecendo encorajamento, sabedoria, inspiração; louvando Jah e tomando posicionamento político contrário à dominação política e econômica do Ocidente, bem como do imperialismo cultural. in PRAHLAD, Anand. Reggae Wisdom, Proverbs in Jamaican Music, 2001 
We're gonna chuck to jah music chuckin'

We're chuckin' to jah music, we're chuckin'

Them belly full but we hungry.

\section{A hungry mob is an angry mob}

A rain a fall but the dirt it tough

A pot a cook but the food no 'nough

\section{A hungry mob is an angry mob}

Meditar sobre a nutrição da condição humana é um problema de vida e de morte, ainda mais neste momento em que as mudanças climáticas começam a potencializar seus efeitos na agricultura ${ }^{101}$, sobretudo, na agricultura de subsistência ${ }^{102}$, até quando o Sol explodir.

101 Decreto $N^{\circ}$ 2.652/1998, promulga a Convenção-Quadro das Nações Unidas sobre Mudança do Clima, assinada em Nova York, em 9 de maio de 1992.

As partes desta Convenção, (i) Reconhecendo que a mudança de clima da Terra e seus efeitos negativos são uma preocupação comum da humanidade; (ii) Observando que as previsões relativas à mudança do clima caracterizam-se por muitas incertezas, particularmente, no que se refere a sua evolução no tempo, magnitude e padrões regionais; (iii) Reafirmando o princípio de soberania dos Estados na cooperação internacional para enfrentar a mudança do clima; (iv) Afirmando que medidas para enfrentar a mudança climática devem ser coordenadas, de forma integrada, com o desenvolvimento social e econômico, de maneira a evitar efeitos negativos neste último, levando plenamente em conta as legítimas necessidades prioritárias dos países em desenvolvimento para alcançar um crescimento econômico sustentável e erradicar a pobreza;

Convieram no seguinte:

\section{Artigo 2 Objetivo}

O objetivo final desta Convenção e de quaisquer instrumentos jurídicos com ela relacionados que adote a Conferência das Partes é o de alcançar, em conformidade com as disposições pertinentes desta Convenção, a estabilização das concentrações de gases de efeito estufa na atmosfera num nível que impeça uma interferência antrópica perigosa no sistema climático. Esse nível deverá ser alcançado num prazo suficiente que permita aos ecossistemas adaptarem-se naturalmente à mudança do clima que assegure que a produção de alimentos não seja ameaçada e que permita ao desenvolvimento econômico prosseguir de maneira sustentável

102 É necessário aprofundarmos, com base, nos estudos de Celso Furtado sobre a economia de subsistência, em sua obra Formação Econômica do Brasil, em virtude de, pela primeira vez na história da humanidade, os camponeses (sentido lato) não serem mais a maioria populacional da Terra, bem como os mais pobres entre pobres. 


\section{1 - O COMITÊ DE DIREITOS ECONÔMICOS, SOCIAIS E CULTURAIS E O SEU MODELO PRESCRITIVO ${ }^{103}$ : O PACTO INTERNACIONAL DE DIREITOS ECONÔMICOS, SOCIAIS E CULTURAIS}

Conforme Georges Saab, eminente professor de Direito internacional, afirma $^{104}$ :

O Direito Internacional, como todo Direito, não emerge do vácuo ou do vazio social, e nem sempre emerge no universo jurídico como um "big bang". Na maioria dos casos, o Direito Internacional é resultado do crescimento progressivo e imperceptível, intermediado pelo processo de desenvolvimento dos valores de uma sociedade; novas ideias aparecem e enraízam-se; elas fortalecem-se em valores que se tornam mais e mais imperativos na consciência social, ao ponto desses valores derem origem a uma convicção irresistível de que eles devem ser formalmente aprovados e protegidos. Esse é o ponto que marca o limiar do Direito.

O primeiro grande suporte ${ }^{105}$ internacional do pensamento jurídico sobre os direitos humanos foi a Declaração Universal de Direitos Humanos, aprovada em 1948. Como a Declaração Universal não tem natureza jurídica de um tratado, a sociedade internacional comprometeu-se a desenvolver os deveres dos Estados posteriormente, mediante a elaboração de dois pactos internacionais: um para os direitos econômicos,

\footnotetext{
103 A missão essencial do CDESC consiste em examinar os informes periódicos dos Estados-partes. in E/CN.4/2003/53 - Os Direitos Econômicos, Sociais e Culturais - Situação dos Pactos Internacionais de Direitos Humanos - Informe do sr. Hatem Kotrane, especialista independente encarregado de examinar a questão do projeto de protocolo facultativo do PIDESC. p.71.

104 ZIEGLER, Jean. The fight for the Right to Food: Lessons Learned, Palgrave Macmillan, 2011. ISBN:9780-230-28464-7.p.4. Cf. G. Abi-Saab, 'Les sources du droit international: essai de déconstruction', In M. Rama-Montaldo, Liber Amicorum en hommage au Professeur Eduardo Jimenez de Aréchaga, Montevideo, Fundación de Cultura Universitaria, 1994, pp. 29- 49.

105 Para significado preciso. cf. nota rodapé 2.p.5. Cap.1.1.Propósitos Dissertativos e a Posição do Tridimensionalismo Jurídico Concreto.
} 
sociais e culturais (PIDESC), e outro para os direitos civis e políticos (PICP). Esses pactos são instrumentos internacionais vinculantes que impõem obrigações jurídicas aos Estados que, ao ratificá-los, se obrigam a garantir a aplicação efetiva desses acordos na jurisdição doméstica, tanto constitucional quanto infraconstitucionalmente.

Em prefácio, escrito em 1979, à $2^{a}$ edição de sua Teoria Tridimensional do Direito, Miguel Reale destaca as necessidades jurídicas dos países em desenvolvimento, apresenta o contexto do Direito no pós-guerra, bem como fundamenta a Teoria Tridimensional desenvolvida por ele.

A iniciativa da Universidade do Chile, em Valparaíso, de incluir a presente monografia em sua coletânea intitulada Juristas Perenes, além do significado pessoal que naturalmente me envaidece, revela quanto as nações do impropriamente denominado "Terceiro Mundo" sentem e vivem a necessidade de uma compreensão antiformalista do Direito.(gn)

As perplexidades e os anseios inerentes à nossa vida cultural, na totalidade das suas projeções, desde as artísticas às econômicas e políticas, refletem-se no sentido de soluções jurídicas concretas, vinculadas à experiência e aos valores da vida cotidiana.(gn)

A Ciência do Direito, sobretudo a partir da Segunda Grande Guerra, vem se caracterizando por uma crescente luta contra o formalismo, o que implica repúdio às soluções puramente abstratas. Deseja-se, cada vez mais, correlacionar as soluções jurídicas com a situação concreta na qual vivem os indivíduos e os grupos. (gn)

Essa tendência, no campo do Direito, não é senão expressão das diretrizes e do movimento que caracterizam, de modo geral, a cultura contemporânea.

[...] A Ciência Jurídica, que é uma das componentes essenciais do mundo da cultura, passou a abandonar a colocação de seus problemas de maneira abstrata, 
evitando discussões meramente verbais, e, por conseguinte, certas contraposições genéricas ou absolutas que suscitaram, até bem pouco tempo, polêmicas infecundas.(gn)

Daí falar-se, especialmente nas últimas décadas, em Direito como experiência, terminologia que prefïro, e que é, aliás, o título de uma de minhas obras principais; em concreção jurídica, ou no Direito como vida humana objetivada, todas expressões que, apesar da ideia que as distinguem, correspondem, porém, a uma mesma aspiração no sentido de harmonizar a lógica das regras jurídicas com as exigências reais da vida social.(gn)

Nesse sentido, verificam- se, campo jurídico, algumas alterações de fundo, como a afirmação, por exemplo, de uma verdade, esquecida no clima individualista anterior, de que o legislador e o jurista devem ter sempre presentes alguns pressupostos básicos de ordem moral. [...] É impossível reduzir a vida jurídica a meras fórmulas lógicas ou a um simples encadeamento de fatos, devendo reconhecer-se a essencialidade dos princípios éticos, o que explica o frequente apelo que se volta a fazer a ideias, como de equidade, probidade, boa-fé etc., a fim de captar-se a vida social na totalidade de suas significações para o homem situado "em razão de suas circunstâncias".

Nesse contexto parece-me lícito afirmar que o tridimensionalismo jurídico tem o mérito de evitar a redução da Ciência do Direito a uma vaga Axiologia Jurídica, pelo reconhecimento de que não são menos relevantes os aspectos inerentes ao plano dos fatos ou à ordenação das normas, o que implica, penso eu, uma compreensão dialética e complementar dos três fatores operantes na unidade dinâmica da experiência jurídica.(gn) 
Adotada essa posição, o problema da "concreção jurídica" adquire mais seguros pressupostos metodológicos, permitindo- nos apreciar, de maneira complementar, as interdisciplinariedades das diversas pesquisas relativas à realidade jurídica, sob os prismas distintos da Filosofia do Direito, da Sociologia Jurídica, da Ciência do Direito, da Etnologia Jurídica etc. A compreensão unitária e orgânica dessas perspectivas implica o reconhecimento de que, não obstante a alta relevância dos estudos lógico-linquísticos, tudo somado, o que há de essencial no Direito é o problema de seu conteúdo existencial ${ }^{106}$. (gn)

Como todos os outros direitos econômicos e sociais, o direito à alimentação diz respeito à dignidade humana que fundamenta a Declaração Universal de Direitos Humanos. Também diz respeito à luta pela "Terceira Liberdade" do presidente Franklin Roosevelt - "Estar livre das necessidades e da fome". ${ }^{107}$

Por não ter natureza jurídica de um tratado, a Declaração Universal proporcionou o fundamento para o Pacto Internacional de Direitos Econômicos, Sociais e Culturais, segundo o qual incuti no direito à alimentação força legal. Apesar de os instrumentos internacionais em si não terem mecanismos para a aplicação da lei, esses acordos internacionais criam um precedente legal nos países que os ratificam, o que possibilita aos cidadãos ou às cortes cobrarem Estados para cumprirem a obrigação acordada. Esses documentos são negociados nos órgãos internacionais, mas a obrigação de cumprir, como, por exemplo, o direito à alimentação, ou mesmo os direitos humanos em geral, permanece intimamente ligada aos direitos de cidadania e é dependente da aplicação legal em nível nacional. ${ }^{108}$ (gn)

\footnotetext{
${ }^{106}$ REALE, Miguel. Teoria Tridimensional do Direito, situação atual, 5 ed. rev. e aum. - São Paulo: Saraiva, 1994,p.XIII/XV

${ }^{107}$ ZIEGLER, Jean. The fight for the Right to Food: Lessons Learned, Palgrave Macmillan, 2011. ISBN:9780-230-28464-7.p.15.

${ }^{108}$ FAO, Cuaderno de Trabajo sobre el derecho a la alimentación 1. El derecho a la alimentación en el marco internacional de los derechos humanos y en las constituciones. 2013. p.1
} 
A ideologia da Guerra Fria, estruturante do regime pós-guerra, também teve uma função decisiva no desenvolvimento (ou na insuficiência) do direito à alimentação e na erradicação da fome. Depois da criação da DUDH 1948, uma fissura desenvolveu-se entre as duas categorias de direitos que a Declaração tinha estruturado. Enquanto os Estados Unidos favoreciam os direitos negativos "civis e políticos" (que dizem respeito ao direito que um indivíduo tem de estar livre de violações), a União Soviética apoiava os direitos positivos "econômicos, sociais e culturais" (que dizem respeito ao direito que o indivíduo tem face ao Estado). A recusa de cada lado de reconhecer a categoria de direito apoiada por cada lado significou que, quando chegou o momento de elaborar os deveres dos Estados em relação aos direitos humanos, as Nações Unidas elaboraram dois Pactos Internacionais de direitos humanos separados ${ }^{109}$.

Dentre os instrumentos jurídicos internacionais, os tratados de direitos humanos constituem uma categoria especial em razão de ter como características, entre outras coisas, o fato de que as pessoas aparecem como as titulares dos direitos e os Estados como os titulares das obrigações ${ }^{110}$.(gn)

${ }^{109}$ WITTMAN, Hannah. Food Sovereignty: reconnecting food, nature and community. ISBN 979-1-55266374-5.p.20

${ }^{110}$ FAO, Cuaderno de Trabajo sobre el derecho a la alimentación 1. El derecho a la alimentación en el marco internacional de los derechos humanos y en las constituciones. 2013. p.1 


\subsection{1 - RITO DAS PROPOSIÇÕES NORMATIVAS DO}

\section{PIDESC}

Em 1948, a Assembleia Geral pediu à Comissão de Direitos Humanos que preparasse, com caráter prioritário, um projeto de pacto sobre direitos humanos e um projeto de medidas de aplicação. A Comissão estudou o texto do projeto de pacto em 1949 e, no ano seguinte, reviu os primeiros dezoito artigos, baseando-se em comentários aduzidos pelos Governos. Em 1950, a Assembleia Geral votou uma resolução declarando que «o gozo das liberdades civil e política e dos direitos econômicos, sociais e culturais estão interligados e são interdependentes». Então, a Assembleia decidiu incluir, no pacto sobre os direitos humanos, os direitos econômicos, sociais e culturais, bem como o reconhecimento explícito da igualdade do homem e da mulher em direitos afins, conforme previsto na Carta. Em 1951, a Comissão redigiu catorze artigos sobre direitos econômicos, sociais e culturais, baseando-se em propostas apresentadas pelos Governos e em sugestões de agências especializadas. Preparou também dez artigos sobre medidas de aplicação desses direitos, com base nas quais os Estados-partes no Pacto enviariam relatórios periódicos. Depois de um longo debate, na sessão de 1951, a Assembleia Geral pediu à Comissão que «elaborasse dois pactos sobre direitos humanos, sendo um relativo aos direitos civis e políticos e o outro, aos direitos econômicos, sociais e culturais». A Assembleia especificou que os dois pactos deveriam incluir tantas cláusulas similares quanto possível e que deveriam conter um artigo que garantisse que «todos os povos terão direito à autodeterminação».

Tendo considerado desde sua nona sessão os rascunhos dos Pactos Internacionais de Direitos Humanos, que foram preparados pela Comissão de Direitos Humanos e transmitidos à Assembleia Geral pela resolução 545 B (XVIII) do ECOSOC de 29 de julho de 1954, e tendo completado a elaboração dos Pactos em sua vigésima primeira sessão, Assembleia Geral das Nações Unidas aprovou, no dia 16 de dezembro de 1966, a Resolução 2200 (XXI), em que adotava e abria para assinatura, ratificação e adesão os seguintes instrumentos:
a) o Pacto Internacional de Direitos Econômicos, Sociais e Culturais ${ }^{111}$;
b) o Pacto Internacional de Direitos Civis e Políticos;
c) o Protocolo Opcional do Pacto de Direitos Civis e Políticos.

${ }^{111}$ O PIDESC foi promulgado e ratificado pelo Brasil por meio do Decreto 591 de 06/07/1992. 


\subsection{2 - OS MODELOS JURÍDICOS DO TRIDIMENSIONALISMO E O COMITÊ DE DIREITOS ECONÔMICOS, SOCIAIS E CULTURAIS.}

Antes de definir o direito à alimentação, positivado no artigo 11 do PIDESC, é importante entender a classificação feita por Miguel Reale a respeito dos "modelos" jurídicos.

A bem ver, as estruturas da experiência jurídica positivada são antes "modelos", por ser-lhes inerente um sentido paradigmático de conduta ou de ordenação. Tenho observado, em mais de uma oportunidade, que a teoria dos modelos jurídicos distintos dos modelos hermenêuticos não substitui a teoria das fontes do Direito, vem, sem dúvida alguma, completá-la, colocando-a em novos termos. Embora sem concordar com o normativismo jurídico formal de Kelsen, podemos aceitar a sua afirmação de que as normas constituem "o conteúdo material das fontes do Direito".(gn)

Toda a Ciência Jurídica atual, a partir de Savigny, baseia-se na teoria das fontes, isto é, a partir das regras enunciadoras de uma "classe de ação possível", para empregarmos palavras de Benedetto Croce. As fontes são, desse modo, retrospectivas, o que fez Karl Marx - que seguiu as aulas de Savigny - dizer, ironicamente, que este nos dá uma compreensão $a$ posteriori da história, de tal modo que "o barqueiro parece navegar, não sobre o rio, mas sobre suas nascentes". ${ }^{112}$

Os modelos, ao contrário, são prospectivos e resultam das fontes como estruturas de comportamento futuro. O termo "modelo jurídico" foi por mim proposto, preliminarmente, em comunicação ao Congresso Internacional de Viena, em 1968, e em $\underline{O}$ Direito como Experiência, do mesmo ano. $\mathbf{O}$ conceito de

${ }^{112}$ REALE, Miguel. Teoria Tridimensional do Direito, situação atual, 5 ed. rev. e aum. - São Paulo: Saraiva, 1994,p111. cf. WOLF Paul, Marx versus Savigny, in Anales de la Cátedra Francisco Suarez, nº18-19,19789,p.248. 
modelo, em todas as espécies de ciências, não obstante as suas naturais variações, está sempre ligado à ideia de planificação lógica e à representação simbólica e antecipada dos resultados a serem alcançados por meio de uma sequência ordenada de medidas ou prescrições. Cada modelo expressa, pois, uma ordenação lógica de meios e fins, assim como o "modelo arquitetônico", por exemplo, é um projeto que antecipa e condiciona a construção de um edifício. Coisa análoga ocorre com os modelos mecânicos, matemáticos e, penso eu, também com os jurídicos do Direito.(gn)

Há duas espécies de modelos do Direito: uns são de caráter puramente teórico (modelos dogmáticos ou hermenêuticos); outros são "prescritivos" e representam os modelos jurídicos (stricto sensu). Estes muito embora pressuponham uma elaboração doutrinária, possuem caráter prescritivo e obrigatório, pois representam a opção por determinadas formas de organização ou de conduta, consideradas "em vigor" pela autoridade que lhes confere coercibilidade.

$\mathrm{O}$ que distingue, em suma, os modelos doutrinários ou hermenêuticos, dos modelos jurídicos prescritivos, é que aqueles não são obrigatórios, enquanto nestes existe a previsão ou a prefiguração de uma "ordem de competências",ou, então, de uma "ordem da conduta", estando sempre determinadas as consequências que advêm de seu adimplemento ou de sua violação.(gn)

Observo, desde logo, que um modelo jurídico pode ser expresso por uma única regra de direito ou por um conjunto de regras interligadas, conforme a amplitude da matéria: em ambos casos, porém, há sempre uma "estrutura normativa" constituindo uma unidade de fins a serem atingidos, em virtude da decisão tomada pelo emanador do modelo.

É preciso notar, outrossim, que, quando emprego expressões como modelos do Direito ou modelos 
jurídicos, não me refiro a nenhum protótipo ideal, a algo que se ponha como alvo superior a ser atingido. Os modelos jurídicos, objeto de estudo por parte dos juristas, e por eles aplicados, são antes modelagens práticas da experiência, formas de viver concreto dos homens, podendo ser vistos como estruturas normativas de fatos segundo valores, instauradas em virtude de um ato concomitante de escolha e prescrição ${ }^{113}$.

Para acompanhar a efetivação do PIDESC foi criado o Comitê de Direitos Econômicos, Sociais e Culturais, o que foi feito por meio da Resolução 1985/17 do ECOSOC, órgão das Nações Unidas que, entre 1966 e 1985, era encarregado de monitorar a aplicação do tratado em apreço. O funcionamento do Comitê é regulado pela Resolução acima e pelo próprio Pacto (artigos 16-25). O Comitê é estreitamente vinculado ao ECOSOC, ao qual deve dirigir relatórios periódicos e recomendações que este, por sua vez, encaminhará à Assembleia Geral e a outros organismos do Sistema das Nações Unidas $^{114}$.

Os 160 Estados que ratificaram o Pacto Internacional de Direitos Econômicos, Sociais e Culturais ${ }^{115}$ estão obrigados à realização progressiva do direito à alimentação em âmbito nacional. $\mathrm{O}$ direito à alimentação e as medidas que devem ser efetivadas significam que os Governos não devem efetivar ações que resultem em crescentes níveis de fome, insegurança alimentar e má-nutrição. Também significa que os Governos devem proteger os povos de ações de terceiros que podem violar o direito à alimentação. Enfim, o direito à alimentação não é caridade, mas se trata de garantir que as pessoas tenham a capacidade de se alimentar com dignidade ${ }^{116}$.

113113 REALE, Miguel. Teoria Tridimensional do Direito, situação atual, 5 ed. rev. e aum. - São Paulo: Saraiva, 1994,p.111/2.

${ }^{114}$ PORTELA, Paulo Henrique Gonçalves. Direito Internacional Público e Privados, incluindo noções de direitos humanos e de direito comunitário. 3 ed. , editora juspodium. p.761.

${ }^{115}$ FAO, Cuaderno de Trabajo sobre el derecho a la alimentación 1. El derecho a la alimentación en el marco internacional de los derechos humanos y en las constituciones. 2013. p.3

${ }^{116}$ ZIEGLER, Jean. The fight for the Right to Food: Lessons Learned, Palgrave Macmillan, 2011. ISBN:9780-230-28464-7.p.16. 


\subsection{3 - A DUPLA VERTENTE DO DIREITO À}

\section{ALIMENTAÇÃO}

O direito humano à alimentação, previsto no artigo 11 do PIDESC, conta com uma dupla vertente: o direito fundamental de estar protegido contra a fome e o direito a uma alimentação adequada.(gn)

Tal qual todos os direitos humanos, o maior desafio com respeito ao direito à alimentação é o de encontrar maneiras mais efetivas de implementá-lo. Dessa maneira, cabem perguntas que tentam responder como esse direito pode ser realizado, concretamente, em nível nacional e como as autoridades públicas podem ser consideradas responsáveis por suas ações incompletas ou por suas omissões.

De acordo artigo 2.1. do PIDESC, cada Estado-parte está obrigado a tomar medidas, em particular medidas legislativas, para a realização progressiva dos direitos contidos no tratado.

$\S 1$. Cada Estado-parte no presente Pacto compromete-se a adotar medidas tanto por esforço próprio como pela assistência e cooperação internacionais, principalmente nos planos econômico e técnico, até o máximo de seus recursos disponíveis, que visem a assegurar, progressivamente, por todos os meios apropriados, o pleno exercício dos direitos reconhecidos no presente Pacto, incluindo, em particular, a adoção de medidas legislativas.

O Direito Internacional dos Direitos Humanos não obriga, formalmente, os Estados-partes a incorporarem as provisões do Pacto, literalmente, no direito doméstico. Em última instância, cada Estado-parte do PIDESC deve determinar o status jurídico que serão dados às provisões - nesse caso, o direito à alimentação - dentro do sistema jurídico. Dependendo do sistema jurídico e constitucional do país, as provisões do tratado internacional podem tornar-se lei nacional tanto por "incorporação automática," em que ela tem força de lei direta e imediatamente ${ }^{117}$, quanto por "incorporação legislativa", em que as provisões dos tratados devem ser implementadas por legislação doméstica para ter efeito

${ }^{117}$ FAO, Guide on Legislating for the Right to Food.2009, pg 1. Conhecido como "Sistema Monista," mesmo em países com esse sistema, algumas provisões de tratado internacional (denominadas provisões não autoaplicáveis) ou alguns aspectos das provisões do tratado podem requerer a implementação legislativa antes de serem aplicados por juízes nacionais. 
vinculante $^{118}$. Em alguns outros Estados, a execução doméstica de um tratado internacional ratificado ocorre por meio do método da transformação, qual seja, por meio de emenda de relevantes leis domésticas para torná-las consistentes com as obrigações dos tratados.

Diferentemente dos outros direitos de cunhos civil e político segundo os quais um indivíduo os goza como um sujeito ou como um membro de dado grupo social é difícil estabelecer precisamente em determinado momento quem seria diretamente afetado no evento em que os direitos econômicos, sociais e culturais estão em jogo. Uma objeção similar pode ser feita devido ao grau de dificuldade em determinar em tal evento, qual seria a autoridade responsável por tal violação. Por isso, em última instância, os direitos sociais dependem da assistência ativa do Estado, da assunção de dever ou de obrigação da parte do Estado para prover os recursos necessários à realização dessa categoria de direitos humanos.

De fato, ao considerar provisões relevantes do tratado internacional sobre o direito à alimentação, a maioria das obrigações sob esse direito não é autoaplicável, ou seja, o direito não tem aplicabilidade sem a ajuda da legislação. Além disso, a natureza complexa e interdisciplinar do direito à alimentação e sua interdependência em relação aos outros direitos humanos demandam ação legislativa, mesmo onde o PIDESC e outros tratados relevantes de direitos humanos sejam diretamente aplicáveis dentro da ordem jurídica nacional. Isso ocorre, porque a incorporação do direito à alimentação no sistema doméstico legal, por efeito da ação legislativa pode prover um alto nível de proteção desse direito humano. ${ }^{119}$ Dessa forma, qualquer pessoa que tenha seu direito à alimentação violado, em sua acessibilidade, em sua disponibilidade ou em seu aspecto de adequação, pode confiar na provisão legal incorporada e demandar um remédio apropriado perante autoridades judiciais e administrativas competentes.

Segundo o artigo 11 do Pacto Internacional de Direitos Econômicos, Sociais e Culturais:

1- Os Estados-partes no presente Pacto reconhecem o direito de toda pessoa a um nível de vida adequado para si próprio e para sua família, inclusive à alimentação, vestimenta e moradia adequadas, assim como uma melhoria contínua de suas condições de vida. Os Estados-partes tomarão medidas apropriadas para assegurar a consecução desse direito, reconhecendo, nesse sentido, a importância essencial da

\footnotetext{
${ }^{118}$ FAO, Guide on Legislating for the Right to Food.2009, pg1. Conhecido como "Sistema Dualista."

${ }^{119}$ FAO, Guide on Legislating for the Right to Food.2009, pg2
} 
cooperação internacional fundada no livre consentimento.

2. Os Estados-partes no presente Pacto, reconhecendo o direito fundamental de toda pessoa de estar protegida contra a fome, adotarão, individualmente e mediante cooperação internacional, as medidas, inclusive programas concretos, que se façam necessários para:

a) Melhorar os métodos de produção, conservação e distribuição de gêneros alimentícios pela plena utilização dos conhecimentos técnicos e científicos, pela difusão de princípios de educação nutricional e pelo aperfeiçoamento ou reforma dos regimes agrários, de maneira que se assegurem a exploração e a utilização mais eficazes dos recursos naturais.

b) Assegurar uma repartição equitativa dos recursos alimentícios mundiais em relação às necessidades, levando-se em conta os problemas tanto dos países importadores quanto dos exportadores de gêneros alimentícios

$\mathrm{O}$ direito de estar protegido contra a fome, intimamente vinculado ao direito à vida, considera-se como uma norma absoluta, o nível mínimo que se deve garantir a todas as pessoas, independentemente do nível de desenvolvimento alcançado pelo Estado $^{120}$.

O direito a uma alimentação adequada abarca muito mais, uma vez que esse direito comporta a necessidade de constituir um entorno econômico, político e social que permita às pessoas alcançar a segurança alimentar por seus próprios meios. ${ }^{121}$

${ }^{120}$ FAO, Cuaderno de Trabajo sobre el derecho a la alimentación 1. El derecho a la alimentación en el marco internacional de los derechos humanos y en las constituciones. 2013. p.4.

${ }^{121}$ ibidem.p.4 


\subsection{4 - FOME : VIOLAÇÃO DO ARTIGO 11 DO PIDESC}

Segundo o primeiro Relator Especial para o Direito à Alimentação, Jean Ziegler $^{122}$ :

Entre todos os direitos do homem, o direito à alimentação é, certamente, aquele que é mais constantemente e mais massivamente violado em nosso planeta.

Segundo as estimativas da Organização das Nações Unidas para a Alimentação e a Agricultura (FAO) ${ }^{123}$, o número de pessoas grave e permanentemente subalimentadas no planeta chegava, entre 2010-12, a 870 milhões. O número de pessoas famintas no mundo permanece inaceitavelmente alto. A vasta maioria vive em países em desenvolvimento, onde 850 milhões de pessoas, ou pouco menos de $15 \%$ da população, são estimadas estarem subnutridas. $60 \%$ de todas as pessoas subnutridas vivem em sete países: Bangladesh, China, República Democrática do Congo, Etiópia, Índia, Indonésia e Paquistão. $43 \%$ dessas pessoas famintas encontram-se na China e na Índia ${ }^{124}$.

O fenômeno da fome pode ser abordado de maneira simples ${ }^{125}$. A comida (ou o alimento), seja de origem vegetal ou animal (às vezes, mineral), é consumida pelos seres vivos com fins energéticos e nutricionais. Os elementos líquidos (como a água de origem mineral) - ou, dito de outra forma, as bebidas (consideradas alimento, quando são sopas, caldos etc) - são ingeridos com a mesma finalidade.Todos esses elementos, em conjunto, compõem o que se designa como alimentação.

Essa alimentação constitui a energia vital do homem. A unidade energética chamada reconstitutiva é a quilocaloria. Ela permite avaliar a quantidade de energia necessária ao corpo para se reconstituir. Uma quilocaloria contém mil calorias. Aportes energéticos insuficientes (subnutrição), uma carência de quilocaloria, provocam a fome e, depois, a morte. As necessidades calóricas variam em função da idade: setecentas calorias diárias para um lactente, mil para um bebê entre um e dois anos, 1.600 para uma

\footnotetext{
${ }^{122}$ ZIEGLER, Jean. Destruição Massiva- Geopolítica da Fome. éditions du Seuil, Paris, 2011. p.19

${ }^{123}$ FAO, WFP and IFAD. 2012. The State of Food Insecurity in the World 2012.

Economic growth is necessary but not sufficient to accelerate reduction of hunger and malnutrition. Rome, FAO. ISBN 978-92-5-107316-2

124 FAO, Cuaderno de Trabajo sobre el derecho a la alimentación.Evaluación del derecho a la alimentación.2013.p.8.

${ }^{125}$ ZIEGLER, Jean. Destruição Massiva- Geopolítica da Fome. éditions du Seuil, Paris, 2011. p.19 e sgts.
} 
criança de cinco anos. Quanto ao adulto, suas necessidades variam entre 2.000 e 2.700 calorias por dia, conforme o clima sob o qual vive e a natureza do trabalho que realiza. A Organização Mundial da Saúde (OMS) fixa em 2.200 calorias diárias o mínimo vital para um adulto. Abaixo desse mínimo, o adulto não consegue reproduzir satisfatoriamente a sua própria força vital.

Dolorosa é a morte pela fome. A agonia é longa e provoca sofrimentos insuportáveis. Ela destrói lentamente o corpo, mas também o psiquismo. A angústia, o desespero e um sentimento de pânico, de solidão e de abandono acompanham a decadência física.

A desnutrição severa e permanente provoca um sofrimento agudo e lancinante do corpo. Produz letargia e debilita, gradualmente, as capacidades mentais e motoras. Implica marginalização social, perda de autonomia econômica e, evidentemente, desemprego crônico pela incapacidade de executar um trabalho regular. Conduz inevitavelmente à morte.

A agonia provocada pela fome passa por cinco estágios.

Salvo raras exceções, um homem pode viver normalmente três minutos sem respirar, três dias sem beber e três semanas sem comer. Não mais. Então começa a agonia.

Entre crianças subalimentadas, a agonia se anuncia muito mais rapidamente. O corpo esgota primeiro as suas reservas de açúcar e depois as de gordura. As crianças entram num estado de letargia. Depressa perdem peso. Seu sistema imunitário colapsa. As diarréias aceleram a agonia. Parasitas bucais e infecções das vias respiratórias causam sofrimentos espantosos. Começa, então, a destruição da massa muscular. As crianças já não conseguem manter-se de pé. Como alguns pequenos animais, encolhem-se sobre si mesmas no chão. Seus braços pendem sem vida. Seus rostos assemelham-se àqueles dos idosos. Finalmente, sobrevém a morte.

No ser humano, os neurônios do cérebro formam-se entre zero e cinco anos. Se nesse lapso, a criança não receber uma alimentação adequada, suficiente e regular, ficará lesionada por toda a vida. Em contrapartida, um adulto que, atravessando o deserto do Saara, tenha sofrido uma pane em seu carro e, por isso, foi privado de alimentação por algum tempo, antes de ser salvo in extremis, poderá recuperar sem problema sua vida normal: uma "renutrição" administrada sob controle médico lhe permitirá restabelecer a totalidade de suas forças físicas e mentais. Vê-se, pois, que não é esse o caso de uma 
criança de menos de cinco anos privada de alimento adequado e suficiente. Mesmo se, ulteriormente, ela desfrutar de condições milagrosamente favoráveis - que seu pai encontre trabalho, que seja adotada por uma família com recursos etc -, seu destino estará selado. Será uma crucificada de nascimento, uma lesionada cerebral por toda a vida. Nenhuma alimentação terapêutica poderá assegurar-lhe uma vida normal, satisfatória e digna. Num grande número de casos, a subalimentação provoca as chamadas doenças da fome: a noma, o kwashiorkor etc. Ademais, ela debilita perigosamente as defesas imunitárias das suas vítimas.

A maldição da fome prolonga-se biologicamente. A cada ano, milhões de mulheres subalimentadas dão à luz crianças condenadas desde o nascimento. Estas já são vítimas de carências antes mesmo do seu primeiro dia sobre a Terra. Durante a gravidez, a mão subalimentada transmite essa maldição à sua criança. A subalimentação fetal provoca invalidez definitiva, danos cerebrais e deficiências motoras. Uma mãe esfaimada não pode aleitar seu bebê, nem dispõe dos recursos necessários para comprar um sucedâneo lácteo. Nos países do Sul, 500.000 mulheres morrem, anualmente, no parto, a maioria por falta prolongada de alimentos durante a gravidez.

Romper com este ciclo intergeracional é extraordinariamente importante: não é só uma questão ética fundamental, mas também uma prioridade para todo governo que se preocupe com a futura capacidade intelectual e econômica de sua população ${ }^{126}$.

\section{A fome é, pois, e de longe, a principal causa de morte e de desamparo}

\section{em nosso planeta. (gn)}

Para circunscrever melhor a geografia da fome ${ }^{127}$, a distribuição dessa destruição massiva sobre o planeta, é preciso, de início, recorrer a uma primeira distinção, qual se referem a ONU e suas agências especializadas: a "fome estrutural", de um lado, e, de outro, a "fome conjuntural".

A fome estrutural é própria das estruturas de produção insuficientemente desenvolvidas dos países do Sul. Ela é permanente, pouco espetacular e se reproduz biologicamente: a cada ano, milhões de mães subalimentadas dão à luz milhões de crianças deficientes. A fome estrutural significa destruição psíquica e física, aniquilação da dignidade, sofrimento sem fim.

${ }^{126}$ EIDE, Asbjorn. E/CN.4/Sub.2/1999/12 - O direito a uma alimentação adequada e a não padecer de fome.Estudo atualizado sobre o direito à alimentação apresentado pelo sr. Asbjorn Eide em cumprimento da decisão 1998/106 da Subcomissão de Prevenção de Discriminações e Proteção da Minorias.p.8.

${ }^{127}$ ZIEGLER, Jean. Destruição Massiva- Geopolítica da Fome. éditions du Seuil, Paris, 2011. p.24 
A fome conjuntural, em troca, é altamente visível. Irrompe periodicamente nas telas da televisão. Ela se produz quando, repentinamente, uma catástrofe natural - gafanhotos, uma seca ou inundações assolam um região - ou uma guerra destrói o tecido social, arruína a economia, empurra centenas de milhares de vítimas aos acampamentos de pessoas deslocadas no interior do país ou de refugiados para alémfronteiras. Nessas circunstâncias, não se pode semear nem colher. São destruídos os mercados, as estradas são bloqueadas e as pontes bombardeadas. As instituições estatais deixam de funcionar. Para milhões de vítimas amontoadas nos acampamentos, a última salvação está no Programa Alimentar Mundial (PAM) ${ }^{128}$.

\footnotetext{
${ }^{128}$ O Programa Mundial para a Alimentação (PAM) é a maior agência humanitária que combate a fome no mundo. Criada em 1961, teve se mandato definido pela Assembleia Geral nos seguintes termos:

"eliminar a fome e a pobreza no mundo, ao responder às necessidades urgentes e ao apoiar o desenvolvimento econômico e social"

O PAM deve visar, em particular, à redução das taxas de mortalidade infantil, à melhoria da saúde das mulheres grávidas e a lutar contra as carências de micronutrientes".

in ZIEGLER, Jean. Destruição Massiva- Geopolítica da Fome. éditions du Seuil, Paris, 2011
}

\section{5}




\section{3 - O PROCESSO AXIOLÓGICO-FACTUAL} NORMATIVO DOS DIREITOS ECONÔMICOS, SOCIAIS E CULTURAIS E A MODERNA REFLEXÃO DOS DIREITOS HUMANOS

Segundo Miguel Reale, a norma é a forma que o jurista usa para expressar o que deve ou não ser feito para a realização de um valor ou para impedir a ocorrência de um desvalor. Acontece, porém, que a norma jurídica está imersa no mundo da vida (Lebenswelt), ou seja, na nossa vivência cotidiana, no nosso ordinário modo de ver e de apreciar as coisas. Ora, o mundo da vida muda, então, acontece uma coisa que é muito importante e surpreendente: uma norma jurídica, sem sofrer qualquer alteração gráfica, como o artigo 11 do PIDESC, sem ter alteração alguma de uma vírgula passa a significar algo de diverso, em consonância com os princípios de equidade ${ }^{129}$.

Miguel Reale costuma oferecer a seguinte representação gráfica do "processo axiológico-factual normativo", que demonstra as alterações do alcance e do significado das normas jurídicas em virtude de alteração no plano dos fatos.

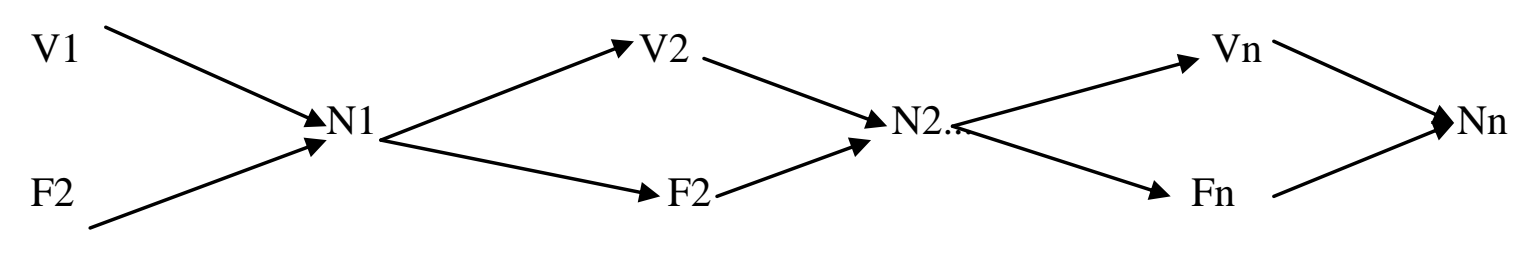

Esse gráfico serve para mostrar que uma norma jurídica, uma vez emanada, sofre alterações semânticas, pela superveniência de mudanças no plano dos fatos e dos valores, até se tornar necessária sua revogação ${ }^{130}$. Mas a norma não é uma coisa assim que se puxe para lá e para cá. Pontes de Miranda dizia, sabiamente, que a norma jurídica tem certa elasticidade. A norma é elástica. Mas chega um certo momento em que a elasticidade não resiste e a norma se rompe. Logo, as variações na interpretação da norma devem ser compatíveis com sua elasticidade. Pois bem, quando a norma deixa de corresponder às necessidades da vida, ela deve ser revogada, para nova solução normativa

\footnotetext{
${ }^{129}$ REALE, Miguel. Teoria Tridimensional do Direito, situação atual, 5 ed. rev. e aum. - São Paulo: Saraiva, 1994,p.125.

${ }^{130}$ idem.p.101.
} 
adequada, o que nos revela a riqueza das soluções que a vida jurídica apresenta ${ }^{131}$.

Alerta Miguel Reale ${ }^{132}$ que não é demais lembrar que essas alterações do alcance e significado das normas jurídicas é objeto de estudos especiais de Semântica Jurídica, uma das partes da Lógica Jurídica, que não é mais apenas a Lógica dos silogismos, o que demonstra que as variações operadas na vida jurídica dão nascimento a novos ramos do saber jurídico.

Dentro da moderna reflexão sobre os direitos humanos, frequentemente se distinguem três grandes grupos de atores (stakeholders) implicados na realização deles: os titulares de direitos, os titulares de obrigações e os titulares de responsabilidades ${ }^{133}$.

Os titulares de direitos são todos os seres humanos. Qualquer pessoa, pelo mero fato de sê-la, é sujeito de direitos humanos, o que lhe permite reclamar níveis mínimos de trato, de coberturas, de serviços e de oportunidades. É importante que os titulares de direitos possam desenvolver suas próprias capacidades de exercê-los, que sejam conscientes de sua realidade e possam tomar decisões sobre o próprio desenvolvimento. Contudo, existem acontecimentos e circunstâncias de diversas natureza política, econômica, cultural ou social - que podem influir, condicionar e limitar o exercício dos titulares de direitos humanos. Por isso, é conveniente constituir uma cidadania participativa e reivindicativa, consciente de seus direitos, com capacidade de reclamá-los.

No âmbito específico dos tratados de direitos humanos e, em particular os dois pactos da Carta Internacional de Direitos Humanos, os titulares de obrigacões são as instituições de cada Estado que tenha ratificado esses pactos, já que as obrigações em matéria de direitos humanos têm de ser cumpridas, principalmente, pelos Estados. Da mesma forma como apontamos para os titulares dos direitos, há fatores diversos que podem influir ou condicionar os titulares de obrigações para que deixem de cumprir seus deveres. Por isso, é necessário fortalecer as capacidades das instituições (titulares de obrigações) para que sejam conscientes de suas obrigações, respeitadoras dos direitos humanos, transparentes, que desenvolvam tanto a legislação necessária para proteger e

\footnotetext{
${ }^{131}$ ibidem.p. 127

132 ibidem.p. 126

133 FAO. $9^{\circ}$ Caderno de Trabalho sobre o direito à alimentação. Quem é quem no direito à alimentação.2013.p.2 e sgts.
} 
garantir os direitos de cidadania quanto as políticas inclusivas e participativas que promovam sua realização.

O conceito de titulares de responsabilidades é mais amplo e menos preciso, contudo os próprios textos dos instrumentos da Carta Internacional de direitos humanos nos dão pistas de quem podem ser considerados como titulares de responsabilidade. Nesse sentido, o preâmbulo da Declaração Universal de Direitos Humanos assinala que a Organização das Nações Unidas se compromete a cooperar com os Estados-membros para assegurar o respeito universal e efetivo aos direitos e liberdades fundamentais; portanto, apesar de o conjunto de organismos, de programas e de instituições integradas sob o guarda-chuva da ONU não terem a titularidade das obrigações - às quais correspondem a cada Estado-parte, de fato e de iure, esse conjunto têm uma responsabilidade em cooperar com os Estados.

O artigo 29 da Declaração Universal estabelece que, no exercício de seus direitos e no gozo de suas liberdades, toda pessoa estará sujeita somente às limitações estabelecidas pela lei, com o único fim de assegurar o reconhecimento e o respeito dos direitos e liberdades dos demais, bem como de satisfazerem as justas exigências da moral, da ordem pública e do bem-estar geral de uma sociedade democrática. Nessa mesma fundamentação, os preâmbulos de ambos pactos internacionais assinalam que o indivíduo, por ter deveres com respeito aos outros indivíduos e para com a comunidade a que pertence, está obrigado a procurar a vigência e a observância dos direitos reconhecidos nesses pactos. Por isso, entende-se que os indivíduos, a família, a comunidade, as organizações sociais e internacionais sejam titulares de responsabilidades na realização dos direitos humanos. 
A primeira agência especializada da ONU, a Organização para a Alimentação e a Agricultura (FAO), considera, a título de exemplo, os seguintes titulares de responsabilidades para a realização do direito humano à alimentação: (i) movimentos sociais/organizações não governamentais, (ii) instituições financeiras internacionais, com as de Bretton Woods, (iii) FAO, (iv) Programa Mundial para a Alimentação ${ }^{134}$, (v) FIDA ${ }^{135}$ (v) Comitê de Direitos Econômicos, Sociais e Culturais do PIDESC; (vi) Oficina do Alto Comissariado para os Direitos Humanos; (vii) Conselho de Direitos Humanos das Nações Unidas, (viii) Comitê Permanente das Nações Unidas sobre a Nutrição ${ }^{136}$.

Enquanto o direito à alimentação foi consagrado no Pacto Internacional de Direitos Econômicos, Sociais e Culturais desde 1966, esforços para desenvolver e clarificar o seu conteúdo são relativamente novos, especialmente em comparação com outros direitos reconhecidos pelo PIDESC - i.e. direitos trabalhistas. Um número de fatores pode explicar essa situação - entre eles, o fato de os direitos econômicos e sociais, por muito tempo, serem concebidos principalmente como direitos relacionados ao trabalho, sob o pressuposto de que, dado que as pessoas eram parte da força de trabalho formal e, por isso, tinham uma renda decente, a alocação primária dessa renda seria orientada para a satisfação das necessidades básicas, como a nutrição, a moradia e os cuidados médicos. Enquanto esse pressuposto parecia bem sedimentado empiricamente, suas premissas - a inclusão progressiva de toda a população no força de trabalho formal - era excessivamente

${ }^{134}$ O Programa Mundial para a Alimentação é a maior agência humanitária que combate a fome no mundo. Criada em 1961, teve se mandato definido pela Assembleia Geral nos seguintes termos: " eliminar a fome e a pobreza no mundo, ao responder às necessidades urgentes e ao apoiar o desenvolvimento econômico e social. O PAM deve visar, em particular, à redução das taxas de mortalidade infantil, à melhoria da saúde das mulheres grávidas e à lutar contra as carências de micronutrientes". in ZIEGLER, Jean. Destruição MassivaGeopolítica da Fome. éditions du Seuil, Paris, 2011

${ }^{135}$ O Fundo Internacional para o Desenvolvimento Agrícola, uma agência especializada das Nações Unidas (FIDA), foi constituída como uma instituição financeira internacional em 1977, como um dos maiores resultados da Conferência Mundial sobre a Alimentação de 1974.

A Conferência foi organizada em resposta às crises alimentares no início dos anos 1970, que afetaram principalmente os países africanos do Sahel. A Declaração Universal para a Erradicação da Fome e da Má-Nutrição resolveu que "Um Fundo Internacional para o Desenvolvimento Agrícola seria estabelecido imediatamente para financiar projetos de desenvolvimento agrícola que priorizassem a produção de comida em países em desenvolvimento".

Uma das principais conclusões que emergiram daquela conferência foi que as causas de segurança alimentar e de crises alimentares crônicas não eram tanto decorrentes de falhas na produção de alimentos, mas eram problemas estruturais relacionados à pobreza e ao fato de a maioria das populações pobres dos países em desenvolvimento estarem concentradas nas áreas rurais. http://www.ifad.org/governance/index.htm

${ }^{136}$ maiores detalhes sobre o Comitê de Segurança Alimentar serão vistos, quando tratarmos da Cúpula Mundial da Segurança Alimentar de 2009.p.211 e sgts. 
otimista tanto para os países em desenvolvimento, cujo ritmo de inclusão na força de trabalho formal é bem menor do que se pensava, quanto para os países desenvolvidos, onde trabalhos de longa duração e permanentes tornaram-se um exceção e não a regra.

A estratégia política de apoiar os direitos econômicos e sociais do trabalhador na força de trabalho formal provou-se ser muito limitada, pois ela enfraquece ou nega proteção àqueles que têm poucas chances de serem incorporados na força de trabalho formal, e que não têm laços de dependência com alguém que está no mercado formal de trabalho. O paradoxo é que esse grupo está frequentemente incluído na categoria dos mais vulneráveis na sociedade - ou seja, os mais necessitados, os quais deveriam ser os alvos preferenciais dos direitos econômicos e sociais. Nesse sentido, desde o relatório pioneiro de Eide Asbjorn sobre o direito à alimentação adequada de meados da década de 1980,esforços internacionais têm sido devotados para o desenvolvimento do conteúdo dos direitos econômicos e sociais além dos contratos de trabalho formais. Mesmo dentro desse processo, enquanto alguns direitos, como os direitos à saúde, à educação e à moradia, têm juntado bastante atenção de especialistas e dos Estados, o conteúdo do direito à alimentação - junto com o direito à água mais recentemente positivado- só começou a ser desenvolvido de modo sistemático recentemente nas últimas três décadas. Os padrões legais com respeito ao conteúdo do direito à alimentação são, portanto, comparativamente recentes em relação aos padrões desenvolvidos para a justiciabilidade, sem referência a outros direitos.

Outro problema particular é o fato de, enquanto outros direitos econômicos e sociais, como os direitos à saúde e à educação, terem reconhecimento constitucional mais amplo ao redor do mundo, esse não é o caso do direito à alimentação, e, portanto, há muito menos países que reconhecem, expressamente, a provisão constitucional desse direito.

Esses fatores podem criar algumas dificuldades na identificação de uma firme base legal para que se leve um caso de direito à alimentação à corte. Se não existe uma base constitucional expressa para o direito à alimentação, e tampouco há uma base estatutária clara, a justicialização direita dele com base no Pacto Internacional de Direitos Econômicos, Sociais e Culturais e em documentos não vinculantes como a Observação Geral \#12 ou as Diretrizes Voluntárias da FAO, perante cortes nacionais com pouco ou nenhum conhecimento de direito internacional, pode ser uma aposta altamente incerta. Esse é o caso mesmo em sistemas jurídicos (monistas) em que o direito internacional é 
diretamente parte da Lei nacional e pode ser diretamente invocado perante às cortes. As dificuldades aumentam em sistemas duais, em que o direito internacional não é automaticamente incorporado na jurisdição nacional. Além disso, o direito à alimentação é um direito relativamente "novo" e falta-lhe um corpo jurisprudencial consistente para que adjudique novos casos e se aplique novos fatos.

Enquanto essas limitações podem constituir obstáculos para a justiciabilidade, elas não são insuperáveis, uma vez que a maioria das limitações são efeitos da falta da tradição jurisprudencial em identificar o direito à alimentação como um direito autônomo. Não existe impedimento conceitual para definir o conteúdo - ou alguns aspectos dele - do direito à alimentação em um estatuto legislativo ou para incluir o direito à alimentação nas constituições. A experiência de aplicação direta dos instrumentos e de padrões de direitos humanos também é uma prática crescente nas cortes nacionais em diferentes partes do mundo. E a ausência de precedentes jurídicos é apenas o estado das coisas que pode ser gradualmente alterado, quando os casos começarem a serem decididos pelas cortes e se acumularem.

Mesmo nos casos em que o direito à alimentação não estar diretamente consagrado numa constituição nem definido por um estatuto legislativo, nem mesmo quando o direito internacional não puder ser diretamente invocado perante as cortes domésticas - e de fato raros são os casos dele ser invocado nas cortes nacionais experiências de direito comparado destacam um número de modos indiretos de proteger o direito à alimentação por meio de sua judicialização. Algumas dessas experiências podem ser elencadas na África do Sul, Brasil, Argentina, Índia, por exemplo ${ }^{137}$.

${ }^{137}$ COURTIS, Christian. The right to Food as a Justiciable Right: Challenges and Strategies. Max Planck Yearbook of United Nations Law, Volume 11, 2007.p.317-337. 


\section{1 - A SEMÂNTICA JURÍDICA DO DIREITO À ALIMENTAÇÃO E O MODELO DOUTRINÁRIO DA TEORIA TRIDIMENSIONAL DO DIREITO}

Os instrumentos internacionais não vinculantes estabelecem diretrizes, princípios e impõem obrigações morais aos Estados signatários, entretanto os Estados não estão obrigados juridicamente a cumprir suas disposições. Apesar disso, os instrumentos não vinculantes têm contribuído, significativamente, para o desenvolvimento do direito internacional dos direitos humanos. Eles adotam a forma de declarações, de recomendações ou de resoluções ${ }^{138}$.

Antes de analisar esses documentos não vinculantes, bem como os órgãos responsáveis pela feitura e aplicação, é necessário examinar a concepção e a função do modelo doutrinário (ou hermenêutico), conforme foi estabelecido por Miguel Reale.

Em suas palavras :

[...]Os modelos dogmáticos ou hermenêuticos, cujo conjunto corresponde à doutrina ou ao Direito científico, conforme terminologia de Savigny, têm por fim, no campo da Ciência Jurídica, dizer o que os modelos jurídicos significam, isoladamente ou no todo do ordenamento, operando, assim, como uma forma de metalinguagem jurídica.(gn)

Essa referência aos modelos dogmáticos e hermenêuticos já nos leva à terceira estrutura fundamental da experiência jurídica que é a relativa aos princípios e categorias que governam o processo interpretativo das normas jurídicas, tendo-se em vista a sua aplicação ou operabilidade.

Não há direito sem interpretação, como se sabe, desde que foi revelado o círculo vicioso que se oculta na velha parêmia interpretatio cessat in claris $^{139}$, visto como a afirmação de clareza já é o resultado de um ato hermenêutico. O que subsiste, no caso, é a advertência de que o intérprete não deve desviar o sentido de uma regra

\footnotetext{
${ }^{138}$ FAO, Cuaderno de Trabajo sobre el derecho a la alimentación 1. El derecho a la alimentación en el marco internacional de los derechos humanos y en las constituciones. 2013. p.4.

139 o brocardo interpretatio cessat in claris sintetiza o entendimento de que a lei não precisa ser interpretada quando ela for clara ("cessa a interpretação, na clareza").
} 
jurídica, quando este é manifesto. O que é importante, todavia, é salientar a essencialidade do momento hermenêutico, quando a doutrina constitui os "modelos dogmáticos", cuja função é dizer o que os "modelos jurídicos prescritivos" significam. Não basta, com efeito, demonstrar que cada momento da vida jurídica corresponde a uma estrutura complexa, onde diferentes elementos se relacionam ou se contrapõem numa "totalidade de sentido", pois é preciso, também, demonstrar-se a qualidade hermenêutica dessa estrutura.(gn)

Já tive a oportunidade de salientar a ligação essencial entre "norma" e "situação normada", o que corresponde à paralela correlação entre "ato normativo" e "ato interpretativo", a partir da observação fundamental de que não há norma sem que haja interpretação. Resulta desse fato que, ao procurar compreender a norma jurídica, ou seja, ao querer determinar o alcance da prescritividade valorativa inerente à fórmula legal objetivada, o intérprete refaz, de certa forma, o caminho do legislador: vai da norma ao fato, mas tendo presentes os fatos e valores que condicionaram o aparecimento desta, bem como fatos e valores supervenientes.(gn)

É por essa razão que o ato hermenêutico também ocorre numa estrutura que é sincrônica ou homóloga à do ato normativo. Entre um e outro não pode haver interrupção: quando esta se dá, a vida jurídica entra em crise pela verificação da insuficiência ou superamentos dos modelos normativos em vigor, impondo-se a sua substituição.

Como se vê, desde a colocação do problema do Direito Natural até à nomogênese jurídica e a sua interpretação, verificamos que a experiência jurídica não pode ser plenamente entendida sem se ter presente a complexidade de sua estrutura, que não é uma estrutura estática, mas dinâmica, suscetível de ser vista nos quadros de um "historicismo axiológico".

Por essas razões é possível dizer que, desde a análise dos princípios transcendentais da ordem jurídica até a empírica interpretação de suas normas particulares, a vida do direito desdobra-se mediante suas estruturas e modelos, cuja natureza e níveis são diversos, mas todos interligados pelo comum propósito de uma objetiva conexão entre meios e fins, ou seja, entre a realidade e a ideia de justiça.(gn) 
Podemos, em conclusão, asseverar que, numa projeção sucessiva, correlacionam-se e desdobram-se três estruturas jurídicas fundamentais: a do Direito Natural, como esquema normativo de exigências transcendentais; a do Direito Positivo, como ordenamento normativo de fatos e valores no plano experiencial; e a da Hermenêutica Jurídica, a qual, além de esclarecer o significado das regras positivas, assegura-lhes contínua atualização e operabilidade ${ }^{140}$.

Os principais instrumentos não vinculantes que reconhecem o direito à alimentação são os seguintes ${ }^{141}$ :

- Declaração Universal sobre a Erradicação da Fome e da MáNutrição, adotada em 1974.(FAO)

- Relatórios, Recomendações e Observações Gerais do Comitê de Direitos Econômicos, Sociais e Culturais, criado em 1987.

- Declaração de Roma sobre Segurança Alimentar Mundial e Plano de Ação da Cúpula Mundial sobre a Alimentação, adotados em 1996. (FAO)

- Aprovação pelo Comitê de Direitos Econômicos, Sociais e Culturais da Observação Geral \#12, "O direito à uma alimentação adequada", em que se definem as distintas obrigações que impõem aos Estados o PIDESC em relação ao direito à alimentação.

- Relatórios e Recomendações do Relator Especial sobre o direito à alimentação, cuja função foi criada em 2000. (Conselho de Direitos Humanos a partir de reforma da Comissão em 2006)

${ }^{140}$ REALE, Miguel. Teoria Tridimensional do Direito, situação atual, 5 ed. rev. e aum. - São Paulo: Saraiva, 1994,p.112/114.

${ }^{141}$ Nota informativa do Relator Especial sobre o direito à alimentação de 2010. 
- Aprovação dos Objetivos de Desenvolvimento do Milênio, em que inclui o objetivo 1 de erradicar a pobreza extrema e a fome até 2015.(Assembleia Geral das Nações Unidas) ${ }^{142}$

- Declaração de Roma sobre Segurança Alimentar, adotada em 2002, em que se pediu o estabelecimento de um grupo de trabalho intergovernamental com o fim de elaborar diretrizes voluntárias para alcançar a realização progressiva do direito à uma alimentação adequada.(FAO)

- Diretrizes Voluntárias da FAO sobre o direito à alimentação, aprovadas em 2004. Elas proporcionam orientações aos Estados para o cumprimento das obrigações que lhes correspondem em relação ao direito à alimentação.

- Conferência Mundial sobre Segurança Alimentar (2009), com a reforma do Comitê de Segurança Alimentar, de modo a torná-lo mais inclusivo a todos os interessados.

142 A Declaração do Milênio é um documento produzido pela Organização das Nações Unidas, decorrente da Cúpula do Milênio (2000), cuja aprovação contou com a assinatura de mais de 189 Estados-membros, representados diretamente por mais de 100 de chefes de Estado, 47 chefes de Governo, 3 Príncipes, 5 VicePríncipes, 3 Primeiros-Ministros e 800 delegados.

Nesse documento, cuja natureza jurídica toma a forma da resolução AGNU 55/2, a Assembleia Geral da ONU, na figura dos Chefes de Estado e de Governo, adotou como valores e princípios, entre outros, o que se depreende do parágrafo 3 da Declaração do Milênio: " Nós reconhecemos que, além de nossas responsabilidades separadas para com nossas sociedades individuais, temos uma responsabilidade coletiva de confirmar os princípios da dignidade humana, da igualdade e da equidade em nível global. Como líderes, nós temos um dever,portanto, com todas as pessoas do mundo, especialmente com as mais vulneráveis e, em particular, com as crianças do mundo, a quem o futuro pertence"

Após a assinatura da Carta de São Francisco, a Declaração do Milênio é o documento que representa um dos maiores compromissos assumidos de forma praticamente consensual pelos Chefes de Estado e de Governo, em que os Estados-membros manifestaram a determinação e a vontade de mudar o mundo, por meio da promoção da paz global, do respeito e da defesa dos direitos humanos, da luta pela erradicação da pobreza, da defesa da democracia, da sustentabilidade ambiental e da promoção dos princípios da dignidade e da equidade humanas. Entre diversos objetivos fundamentais identificados pela resolução, o objetivo primeiro, erradicação da pobreza e da fome, merece ser destacado 


\section{2 - O MODELO HERMENÊUTICO DO DIREITO À} ALIMENTAÇÃO DA ORGANIZAÇÃO DAS NAÇÕES UNIDAS PARA A ALIMENTAÇÃO E A AGRICULTURA (FAO)

\subsection{1 - O HISTORICISMO AXIOLÓGICO DA FAO: ORIGEM E FUNÇÃO}

Até meados do século XX, a fome era como um tabu: o silêncio cobria os túmulos, o massacre era fatal. Como a peste na Idade Média, a fome era considerada como um flagelo insuperável, de tal natureza que a vontade humana, diante dela, nada podia fazer. Mais do que nenhum outro pensador, Thomas Malthus contribuiu para essa visão fatalista da história da humanidade. Se a consciência coletiva europeia, na alvorada da modernidade, permaneceu surda e cega em face do escândalo da morte pela fome de milhões de seres humanos, se até mesmo acreditou encontrar nesse massacre cotidiano uma judiciosa forma de regulação demográfica, tudo isso se deve, em grande parte, a Malthus e à sua grande ideia de "seleção natural"143. Até meados do século XX, a ideologia malthusiana teve efeitos deletérios sobre a consciência ocidental. Ela tornou a maioria dos europeus surdos e cegos diante dos sofrimentos das vítimas, especialmente das colônias. Os famintos haviam se convertido, no sentido etnológico do termo, em tabu ${ }^{144}$.

A experiência coletiva de sofrimento causado pela fome entre os povos europeus teve, no imediato pós-guerra, consequências positivas. Repentinamente, terminada a Segunda Guerra Mundial, o tabu foi quebrado e rompido o silêncio - e Malthus lançado na lixeira da História. Os horrores da guerra, do nazismo, dos campos de extermínio, os sofrimentos e a fome compartilhados provocaram um extraordinário despertar da consciência europeia.

\footnotetext{
${ }^{143}$ ZIEGLER, Jean. Destruição Massiva- Geopolítica da Fome. éditions du Seuil, Paris, 2011. p.77.

${ }^{144}$ ibidem.p. 81
} 
Em seus Manifestos filosóficos, traduzidos por Louis Althusser, Ludwig Feuerbach escrevia ${ }^{145}$ :

A consciência, entendida em seu sentido mais estrito, só existe para um ser que tem por objeto a sua própria espécie e a sua própria essência. [...] Ser dotado de consciência é ser capaz de ciência. A ciência é a consciência das espécies. Ora, apenas um ser que tem por objeto sua própria espécie, a sua própria essência, está capacitado para colocar-se como objeto, em suas significações essenciais, a coisas e seres distintos dele mesmo.

Grandes pesquisadores e profetas pacientes, a quem antes ninguém prestava atenção, viram repentinamente como seus livros vendiam-se às centenas de milhares de exemplares e se traduziam em grande número de idiomas. A figura universalmente conhecida desse movimento é um médico mestiço, natural do miserável Nordeste brasileiro, Josué Apolônio de Castro - seu livro Geopolítica da Fome, publicado em 1951, deu a volta ao mundo. Também outros, de nacionalidades e gerações diferentes, exerceram uma influência profunda sobre a consciência coletiva ocidental - dentre eles, Tibor Mende, René Dumont, o padre Pierre. ${ }^{146}$

Saindo da longa noite do nazismo, uma evidência começava a se colocar, tardando anos a impor-se aos países e aos seus dirigentes: a erradicação da fome é da responsabilidade dos homens - nesse terreno, não existe nenhuma fatalidade. O inimigo pode ser vencido: basta implementar um determinado número de medidas concretas e coletivas para tornar efetivo e objeto de justiça o direito à alimentação.(gn)

Por meio de sua obra científica, Geopolítica da Fome, Josué de Castro derrotou a lei malthusiana da necessidade. Demonstrou que a fome derivava de políticas conduzidas pelos homens e que ela poderia ser vencida, eliminada pelos homens. Nenhuma fatalidade preside o massacre. Trata-se de pesquisar suas causas e combatêlas.(gn)

\footnotetext{
${ }^{145}$ ibidem.p.82 L. Feuerbach, Manifestes philosophiques, tradução de L. Althusser (Paris: PUF, 1960, p. 57-58). [O filósofo alemão L. Feuerbach (1804--1872) teve importante influência sobre a jovem intelectualidade de seu país nos anos 1840;; crítico materialista da filosofia de Hegel (1770--1831), dele está traduzida ao português A essência do cristianismo, Campinas, Papirus, 1988.

${ }^{146}$ ibidem p.13.
} 
Nas palavras do próprio Josué de Castro, a explicação do título da obra:

Embora degradada pela dialética nazista, a palavra geopolítica conserva seu valor científico. [...] Ela procura estabelecer as correlações existentes entre os fatores geográficos e os fenômenos de caráter político.[...] Poucos fenômenos influíram tanto sobre o comportamento político dos povos quanto o fenômeno alimentar e a trágica necessidade de comer. ${ }^{147}$

Fundada em outubro de 1946, com o estímulo de Josué de Castro e seus companheiros,- isto é, um ano e meio depois da criação das Nações Unidas -,44 Estadosmembros da ONU criaram, em Quebec, a Organização para a Alimentação e a Agricultura (FAO), sua primeira instituição especializada. A FAO é o principal organismo nos assuntos relacionados com a alimentação. Ela sediou a Conferência Mundial sobre a Alimentação de 1974, organizou em conjunto com a Organização Mundial de Saúde (OMS) a Conferência Internacional sobre a Nutrição de 1992, organizou as Cúpulas Mundiais sobre a Alimentação de 1996, 2002 e 2009, bem como coordenou os esforços da comunidade internacional para o estabelecimento das diretrizes voluntárias para a realização do direito à alimentação em 2004.

No preâmbulo do tratado constitutivo da FAO, estipula-se que um dos propósitos básicos da organização é o de "liberar a humanidade da fome".

A FAO foi instalada em Roma, com a tarefa de desenvolver a agricultura de víveres e velar pela igual distribuição de alimentos. Em 1946, ela lançou sua primeira campanha mundial contra a fome.

${ }^{147}$ CASTRO, Josué. Geopolítica da Fome. Casa do Estudante do Brasil. RJ, 1951. 
Citamos o artigo $1^{\circ}$ de seu Ato Constitutivo ${ }^{148}$ :

1. A Organização reúne, analisa, interpreta e difunde todas as informações relativas à nutrição, à alimentação e à agricultura. No presente Ato, a palavra agricultura engloba a pesca, os produtos do mar, as florestas e os produtos brutos da exploração florestal;

2. A Organização estimula e se necessário, recomenda toda a ação de caráter nacional e internacional que interesse: à pesquisa científica, tecnológica, social e econômica em matéria de nutrição, alimentação, e agricultura; à melhoria de ensino e da administração, em matéria de nutrição, alimentação e agricultura, bem como a divulgação de conhecimentos teóricos e práticos relativos à nutrição e à agricultura, à conservação dos recursos naturais e à adoção de métodos aperfeiçoados de produção agrícola; a melhoria das técnicas de transformação, comercialização e distribuição de produtos alimentares e agrícolas; à instituição de sistemas eficazes de crédito agrícola no plano nacional e internacional; à adoção de uma política internacional que toca a acordos sobre produtos agrícolas.

148 A sociedade internacional não é composta apenas por Estados. Com efeito, outros entes atuam no âmbito das relações internacionais, dentre as quais entidades criadas e formadas por Estados, com estrutura e personalidade jurídica próprias e com o objetivo de administrar a cooperação internacional em temas de interesse comum. Tais sujeitos de Direito Internacional são as organizações internacionais, também conhecidos como organizações intergovernamentais.

As organizações internacionais são criadas por meio de um tratado, concluído entre os Estados que conceberam sua existência, que funciona como "Ato Constitutivo " da entidade e estabelece sua estrutura, seus objetivos, sua forma de funcionamento, seus órgãos, os processos decisórios da entidade. in PORTELA, Paulo Henrique Gonçalves. Direito Internacional Público e Privados, incluindo noções de direitos humanos e de direito comunitário. 3 ed., editora juspodium. p. 233 


\subsection{1 - A CÚPULA MUNDIAL DA ALIMENTAÇÃO DE 1974 E SUA PROPOSTA NORMATIVA DE SEGURANÇA ALIMENTAR}

A Declaração Universal sobre a Erradicação da Fome e Má-Nutrição foi aprovada em 16 de novembro de 1974 pela Conferência Mundial da Alimentação (FAO), convocada pela Assembleia Geral das Nações Unidas em sua resolução 3180 (XXVIII) de 17 de dezembro de 1973. A Assembleia Geral em sua resolução 3348 (XXIX) incorporou-a em 17 de dezembro de 1974.

A Conferência Mundial da Alimentação foi promovida pela FAO e atendida por representantes de 135 países em resposta à crise mundial de alimentos que atingiu seu ápice em 1972 quando muitas partes do mundo experimentaram colheitas pobres, o que levou a uma venda massiva de grãos americanos para a União Soviética e, por conseguinte, eliminou efetivamente o excedente de grãos no mercado internacional. A essas condições agregaram-se o colapso da pesca da anchova peruana, o que reduziu, enormemente, a oferta de peixe usado para ração animal, e o embargo de petróleo de 1973, que aumentou o custo da produção agrícola industrial ${ }^{149}$.

A crise mundial de alimentos forçou os representantes da sociedade internacional a reconsiderarem suas abordagens em relação à alimentação e à fome. Segurança alimentar entrou pioneiramente no discurso oficial na Declaração da Conferência Mundial da Alimentação, em que demandava um compromisso internacional em relação à segurança alimentar mundial. Apesar de a segurança alimentar não estar, explicitamente, definida na declaração, o termo é usado extensivamente.

O artigo $\mathrm{G}$ da Declaração Universal sobre a Erradicação da Fome e da Má-nutrição afirma:

O bem-estar de todos os povos do mundo depende, em boa parte, da produção e da distribuição adequadas dos alimentos, assim como do estabelecimento de um sistema mundial de segurança alimentar que assegure a disponibilidade suficiente de alimentos a preços razoáveis em todo momento. Independentemente das flutuações e dos caprichos

${ }^{149}$ WITTMAN, Hannah. Food Sovereignty: reconnecting food, nature and community. ISBN 979-1-55266374-5.p.22. 
periódicos do clima e sem nenhuma pressão política nem econômica, e que facilite assim, entre outras coisas, o processo de desenvolvimento dos países em vias de alcançá-lo.

Por toda a Declaração, a segurança alimentar é discutida no contexto de estoques nacionais de alimentos e de desenvolvimento nacional. Quando não é discutida em nível do Estado nacional, a segurança alimentar faz referência à manutenção de estoques de comida suficientes em nível internacional mediante a cooperação entre governos soberanos. Em vez de os preços serem determinados pelo livre mercado, "preços razoáveis" devem ser garantidos sem entraves originados de circunstâncias naturais, políticas e econômicas. Ao garantir a disponibilidade em nível macro, justificava-se a facilitação das metas de desenvolvimento nacional ${ }^{150}$.

Além do desenvolvimento de um novo conceito, como o da segurança alimentar, a Conferência Mundial da Alimentação solenemente declarou que:

1.Todo homem, mulher e criança tem o direito inalienável de estar livre da fome e da má-nutrição de modo que desenvolva completamente e mantenha suas faculdades físicas e mentais. A sociedade já tem os recursos suficientes, a habilidade organizacional e a tecnologia e, portanto, a competência para alcançar esse objetivo. Com efeito, a erradicação da fome é um objetivo comum de todos os países que integram a comunidade internacional, em especial dos países desenvolvidos e de outros que se encontram em condições de prestar ajuda.

A Declaração continua ao afirma, em seu parágrafo 2, que é uma responsabilidade fundamental dos governos "trabalharem juntos para uma maior produção de comida e uma distribuição de comida entre países e dentro dos países mais equitável e eficiente". Além disso, prioridade deve se dada em atacar "a má-nutrição crônica e as enfermidades por carência que afetam os grupos mais vulneráveis e de ingressos baixos".

150 ibidem p. 23. 


\subsubsection{1 - A RELAÇÃO ENTRE NORMA E PROPOSTA}

\section{NORMATIVA}

O conceito de segurança alimentar sofreu uma importante evolução nos últimos 50 anos. Em suas primeiras formulações, destacava-se a disponibilidade dos alimentos. Assim, por exemplo, a Declaração Universal sobre a Erradicação da Fome e da Má-Nutrição (1974) falava do "estabelecimento de um sistema mundial de segurança alimentar que assegurasse a disponibilidade suficiente de alimentos a preços razoáveis em todo momento, independentemente de flutuações e de caprichos periódicos do clima e sem nenhuma pressão política nem econômica".

A evolução do conceito de segurança alimentar ao longo das décadas seguintes fez serem incorporados aspectos muito relevantes, como o acesso, os aspectos nutricionais, os sistemas de sustentação, as estratégias de enfrentamento, o valor cultural dos alimentos, etc ${ }^{151}$.

No final dos anos 1970 e início dos anos 1980, uma mudança relevante ocorreu no discurso referente à segurança alimentar. A mudança conceitual que emergiu realça o poder de compra individual como cerne analítico (linhas de pobreza em relação à renda) e é apoiada por prescrições políticas que favorecem a liberalização dos mercados agrícolas e uma função decrescente dos governos nacionais. Dessa forma, o conceito reformulado reflete, fortemente, o discurso neoliberal e a estrutura do projeto de globalização com ênfase em um regime corporativo para a alimentação ${ }^{152}$.

É impossível precisar a exata origem dessa mudança, uma vez que ela aparece simultaneamente entre acadêmicos trabalhando com temas de segurança alimentar e nas organizações internacionais que tinham originado o conceito. Para entender a natureza dessa reconceitualização, talvez seja melhor começar com o trabalho do prêmio Nobel de Economia, Amartya Sen.

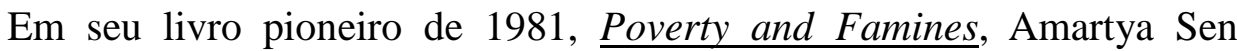
analisou as causas das maiores crises alimentares, para provar que o nível nacional de disponibilidade de comida não se traduzia, necessariamente, em acesso de comida em nível individual. Usando seu próprio conceito de "intitulamento alimentar", Amartya Sen demonstrou que as maiores crises alimentares podiam ocorrer em países onde a

${ }^{151}$ FAO, Cuaderno de Trabajo sobre el derecho a la alimentación 1. El derecho a la alimentación en el marco internacional de los derechos humanos y en las constituciones. 2013. p.9.

${ }^{152}$ WITTMAN, Hannah. Food Sovereignty: reconnecting food, nature and community. ISBN 979-1-55266374-5.p.24. 
disponibilidade geral de comida era suficiente, pelo simples fato de uma certa região ou um grupo ocupacional perde, de forma inesperada, a habilidade econômica para obter comida. Se uma família não tem recursos para comprar alimentos (ela sofre de falha de intitulamento), seus membros passarão fome, independentemente da disponibilidade geral de alimentos num país. Além disso, Amartya Sen apontou que muitas famílias têm diferentes alocações de comida entre seus membros, em que homens frequentemente têm maiores acessos à alimentação do que mulheres e crianças.

As duas maiores mudanças teoréticas contidas no trabalho de Amartya Sen - a redução da escala de análise e o foco no acesso econômico dos alimentos também ocorriam nas Nações Unidas. A definição de segurança alimentar mais comumente usada foi elaborada com base na reformulação do conceito de segurança alimentar na Cúpula Mundial sobre a Alimentação (1996):

Existe segurança alimentar, quando todas as pessoas têm, em todo o momento, acesso material e econômico a alimentos saudáveis e nutritivos suficientes para satisfazerem suas necessidades alimentícias e as preferências alimentares com vistas a levar uma vida ativa e saudável ${ }^{153}$ :

Identificam-se, assim, os quatro pilares básicos da segurança alimentar: (i) disponibilidade, (ii) acessibilidade, (iii) estabilidade, (iv) uso dos alimentos.

Em um grande contraste de como a segurança alimentar foi conceitualizada na imediata ocorrência da crise mundial de alimentos de 1972-3, essa nova definição se apóia no acesso individual em substituição à disponibilidade do estoque nacional. Essas descobertas tiveram grandes repercussões na política de segurança alimentar, bem como na avaliação, que sofreu uma mudança paralela de ênfase do estoque nacional para a quantidade de caloria individual diária.

Apesar de essas mudanças apresentarem um avanço na definição e na avaliação de segurança alimentar, esse novo entendimento também ecoa o discurso neoliberal do projeto de globalização ${ }^{154}$, que tinha começado a tomar forma nos anos 1980.

153 FAO, Cuaderno de Trabajo sobre el derecho a la alimentación 1. El derecho a la alimentación en el marco internacional de los derechos humanos y en las constituciones. 2013.p.9.

${ }^{154}$ Chamamos de "Consenso de Washington" um conjunto de acordos informais concluídos, durante os anos 1980 e 1990, entre as principais sociedades transcontinentais ocidentais (corporações e atores não estatais), os bancos de Wall Street, o Banco de Reserva Federal Americano (FED), o Banco Mundial e o Fundo Monetário Internacional (Organizações Internacionais, nas quais a UE e os Estados Unidos têm poder de veto 
Hodiernamente, segurança alimentar diz respeito às escolhas microeconômicas as quais os indivíduos respondem no livre mercado, ao invés de escolhas políticas as quais os governos respondem. A FAO destaca, explicitamente, esse viés sobre a escolha individual na publicação de seu relatório de $1997^{155}$ :

Segurança Alimentar diz respeito tanto às estratégias individuais para a sobrevivência e o bem-estar quanto aos programas nacionais e investimentos públicos na produção de alimentos e geração de renda.

Esse realce nas decisões de mercado dos indivíduos é parte da ideologia hegemônica neoliberal. Ela também acompanha o inquestionável tratamento de comida como sendo uma commodity ${ }^{156}$.

O relatório do Banco Mundial de 1993, Overcoming Global Hunger, resume bem as implicações desse novo conceito de segurança alimentar:

$\mathrm{Na}$ prática, alimento é uma commodity. Acesso à alimentação é uma função da renda e da distribuição de ativos, assim como do bom ou mau funcionamento da produção alimentar e dos sistemas de mercado. Dessa perspectiva, o acesso à alimentação é governado pelos mesmos fatores que governam o acesso de quaisquer outras mercadorias. É por essa razão que a fome e a pobreza estão tão intrinsecamente ligados ${ }^{157}$.(gn)

O discurso neoliberal do projeto de globalização, com suas tendências individualizantes e mercadológicas, afastou, em meados da década de 1990, o discurso centrado no Estado do projeto de desenvolvimento como a influência primária da segurança alimentar.

em forma de cotas).

Esses acordos informais tinham - e ainda têm como metas - a liquidação de todas as instâncias regulamentadoras, a liberalização dos mercados e a instauração de uma governança global do Estado mínimo, o que em outras palavras significa um mercado mundial unificado e autorregulamentado, entre outros mecanismos a Lei da Oferta e Demanda na Economia, e a LEX MERCATORIA em Direito. Os princípios do "Consenso de Washington" foram teorizados, em 1989, por John Williamson, então, economista-chefe e vicepresidente do Banco Mundial. in ZIEGLER, Jean. Destruição Massiva- Geopolítica da Fome. éditions du Seuil, Paris, 2011.

${ }^{155}$ FAO, 1997.Investindo em Segurança Alimentar.Roma.p.3

${ }^{156}$ WITTMAN, Hannah. Food Sovereignty: reconnecting food, nature and community. ISBN 979-1-55266374-5.p.25.

${ }^{157}$ Banco Mundial. Overcoming Global Hunger. Washington.1993.p.134 
O uso do termo segurança alimentar pela FAO, apesar de menos diretamente influenciada pelas doutrinas neoliberais, também destaca a orientação de mercado em substituição da intervenção estatal. Apesar de a FAO não ter abandonado seu posicionamento tradicional, segundo o qual os governos nacionais devem intervir em nome de seus cidadãos mais vulneráveis, uma importante função do Estado é o de atrair investimento estrangeiro e o de habilitar o funcionamento do livre mercado. Dessa forma, consta no Plano de Ação produzido pela Cúpula Mundial sobre a Alimentação de 1996 o seguinte compromisso ${ }^{158}$ :

4. Os dirigentes do mundo deverão esforçar-se para assegurar que as políticas de comércio alimentar e agrícola e de comércio em geral contribuam para fomentar a segurança alimentar para todos por intermédio de um sistema de comércio mundial leal e orientado ao mercado.

\section{Mesmo na ONU, livre mercado parece ter se tornado uma prioridade} inquestionável $^{159} \cdot$ (gn)

Aos mercados agrícolas atualmente estão confiados a manutenção da segurança alimentar, enquanto a responsabilidade primária do Estado é a de garantir um ambiente econômico que atraia investimentos estrangeiros. Essa ênfase no mercado altera, consideravelmente, a possibilidade de ação estatal, uma vez que a segurança alimentar é um conceito baseado nas necessidades que estabelecem uma meta que deve ser alcançada por meio de programas e políticas estatais, enquanto o direito à alimentação é um conceito de natureza jurídica, em que há os titulares de direitos (as pessoas) e os titulares de obrigações (os Estados) ${ }^{160}$.

Dessa forma, a segurança alimentar pode ser considerada um corolário do direito à alimentação: o Estado deve adotar medidas necessárias para garantir a segurança alimentar a todas pessoas que se encontrem sob sua jurisdição. Em seus esforços nacionais para identificar os grupos que padecem de insegurança alimentar, os Estados deveriam examinar - periodicamente ou quando circunstâncias especiais provoquem mudanças importantes, inclusive as graves depressões econômicas - quem

${ }^{158}$ EIDE, Asbjorn. E/CN.4/Sub.2/1999/12 - O direito a uma alimentação adequada e a não padecer de fome.Estudo atualizado sobre o direito à alimentação apresentado pelo sr. Asbjorn Eide em cumprimento da decisão 1998/106 da Subcomissão de Prevenção de Discriminações e Proteção da Minorias.p.12.

${ }^{159}$ WITTMAN, Hannah. Food Sovereignty: reconnecting food, nature and community. ISBN 979-1-55266374-5.p.26.

${ }^{160}$ FAO, Cuaderno de Trabajo sobre el derecho a la alimentación 1. El derecho a la alimentación en el marco internacional de los derechos humanos y en las constituciones. 2013.p.9. 
pode ser os afetados e as diferentes formas que se podem afetar os distintos grupos segundo sua vulnerabilidade crônica ou transitória ${ }^{161}$.

\subsubsection{2 - QUEM SÃO OS FAMINTOS DO SÉCULO XXI?}

Quem são os mais expostos à fome ${ }^{162}$ no início do século XXI? ${ }^{163}$

Os três grandes grupos de pessoas mais vulneráveis são, na terminologia da FAO, os pobres rurais, os pobres urbanos, e as vítimas das catástrofes naturais ou de conflitos armados.

Detenhamo-nos sobre as duas primeiras categorias.

1. Os pobres rurais. A maioria dos seres humanos que não têm o suficiente para comer pertence às comunidades rurais dos países do Sul. Muitos não dispõem de água potável, nem eletricidade. Nessas regiões, serviços de saúde pública, de educação e de higiene são, em geral, inexistentes. Dos 7,4 bilhões de seres humanos que habitam o planeta, pouco menos da metade vive em zonas rurais.

Desde o início dos tempos, as populações camponesas - agricultores e criadores (como também pescadores)- estão na primeira fila das vítimas da miséria e da fome: atualmente, dos 1.2 bilhão de seres humanos que, segundo os critérios do Banco Mundial, vivem na "extrema pobreza" (ou seja, com uma renda diária inferior a 1,25 dólar), $75 \%$ vivem nos campos.

Inúmeros camponeses vivem na miséria por uma ou outra das três razões seguintes: (i) uns são trabalhadores migrantes sem terra ou arrendatários superexplorados pelos proprietários. Assim, no Norte de Bangladesh, os arrendatários muçulmanos devem entregar a seus senhores da terra indianos, que vivem em Calcutá, quatro quintos de sua colheita. (ii) Outros, se têm terra, não possuem títulos de propriedade suficientemente sólidos. É o caso dos posseiros no Brasil, que ocupam pequenas superfícies de terras improdutivas ou vagas, fazendo uso delas sem ter documentos que provem que elas lhes pertencem. (iii) Outros, ainda, se possuem terra própria, a dimensão e a qualidade desta são

${ }^{161}$ EIDE, Asbjorn. E/CN.4/Sub.2/1999/12 - O direito a uma alimentação adequada e a não padecer de fome.Estudo atualizado sobre o direito à alimentação apresentado pelo sr. Asbjorn Eide em cumprimento da decisão 1998/106 da Subcomissão de Prevenção de Discriminações e Proteção da Minorias.p.20.

162 o termo fome é usado como sinônimo de subnutrição crônica, conforme terminologia usada pela FAO, em seu O Estado da Insegurança Alimentar no Mundo 2013.

${ }^{163}$ ZIEGLER, Jean. Destruição Massiva- Geopolítica da Fome. éditions du Seuil, Paris, 2011. p.25 e sgts 
insuficientes para que possam alimentar decentemente sua família.

Poucos homens e mulheres na Terra trabalham tanto, em circunstâncias climáticas tão adversas e por um ganho mínimo, como os camponeses do hemisfério sul. Raros, entre eles, são os que podem poupar algo para precaver-se contra as sempre ameaçadoras catástrofes naturais e as perturbações sociais. Mesmo quando, durante alguns meses, há alimentação abundante, ressoam tambores em festa, celebram-se matrimônios em grandes cerimônias caracterizadas pela partilha, mesmo então, a ameaça continua onipresente.

90\% dos camponeses do Sul só têm, como instrumentos de trabalho, a enxada, a foice e o machete. Sem tração, os agricultores do Sul permanecerão confinados em sua miséria.

2. Os pobres urbanos ${ }^{164}$. Nas callampas de Lima, nos slums de Karachi, nas smoke mountains de Manila ou nas favelas de São Paulo, as mães de família, para comprar alimentos, têm de se limitar a um orçamento familiar muito restrito. O Banco Mundial estima em 1.2 bilhão de pessoas "extremamente pobres" que vivem com menos de 1,25 dólar por dia.

Em Paris, Genebra ou Frankfurt, uma dona de casa gasta, em média, de $10 \%$ a $15 \%$ do orçamento familiar na compra de alimentos. No orçamento familiar da dona de casa de Manila, a parte destinada à alimentação varia de 80 a $85 \%$ dos seus gastos totais.

No início do século XXI, as pessoas que passam fome se encontram, majoritariamente, entre os consumidores pobres que tiveram reduzido seu poder aquisitivo e têm que destinar, em média, $40 \%$ de seus ingressos para adquirir alimentos (em alguns países, os setores da população mais pobres destinam mais de 70\%). Os preços dos alimentos afetam os mais pobres dos pobres, ou seja, aqueles que carecem de terras, os lares a cargo de mulheres e a população pobre do meio urbano ${ }^{165}$. O menor aumento de preços no mercado provoca, nas favelas, a angústia, a fome, a desintegração familiar, a catástrofe.

\footnotetext{
164 ibidem,p.31.

165 FAO, Cuaderno de Trabajo sobre el derecho a la alimentación.Evaluación del derecho a la alimentación.2013.p.9.
} 
O corte entre os pobres urbanos e os pobre rurais não é, evidentemente, tão radical quanto parece à primeira vista, porque, na realidade, também $43 \%$ dos 2.7 bilhões de trabalhadores sazonais, pequenos proprietários e rendeiros que constituem a imensa maioria dos miseráveis que vivem nos campos devem, em determinados momentos do ano, comprar alimentos no mercado da cidade ou das aldeias vizinhas - já que a colheita anterior não foi suficiente para sustentar a família até a próxima. O trabalhador rural sofre, pois, com os preços elevados do alimento de que tem a mais absoluta necessidade para sobreviver, o que infelizmente confirma a tese central de toda a obra de Josué de Castro segundo a qual Alain Bué a resume com base nessa constatação: "quem tem dinheiro come, quem não tem morre de fome ou se torna um inválido" ${ }^{166}$.

A distribuição da fome no mundo é extremamente desigual. Em 2010, ela se apresentava $\operatorname{assim}^{167}$ :

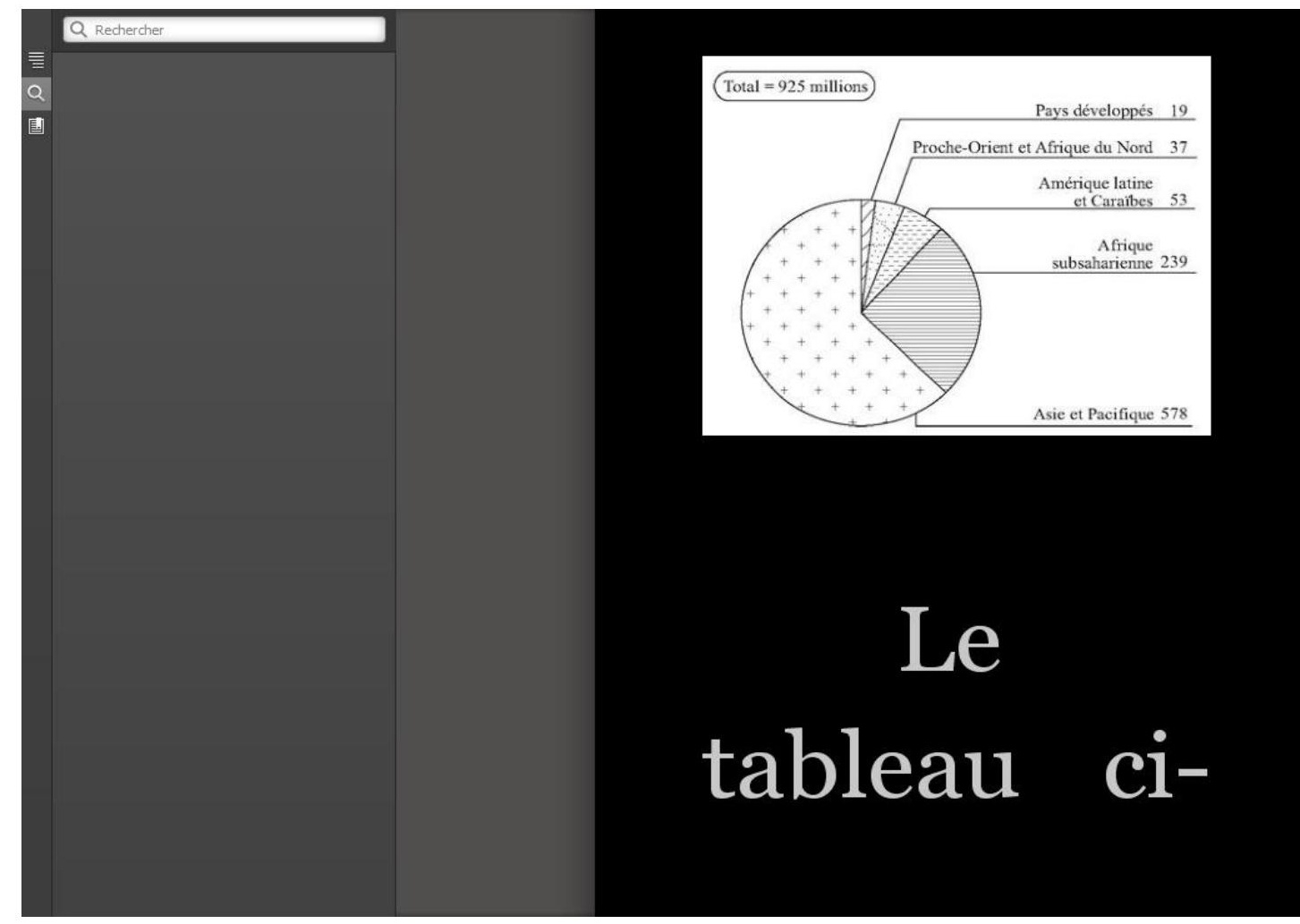

166 ibidem.p.87. Bué Alain," La tragique necessité de manger", in Politics (Paris, outubro--novembro de 2008). Alain Bué foi assistente de Josué de Castro no Centre Universitaire Expérimental de Vincennes, criado em 1968 (depois, Universidade de Vincennes). Professor da Universidade de Paris VIII, é hoje, na França, seu herdeiro intelectual e o guardião de sua obra.

167 Gráfico foi extraído do Relatório sobre a insegurança alimentar no mundo (Roma, FAO, 2010) in ZIEGLER, Jean. Destruição Massiva- Geopolítica da Fome. éditions du Seuil, Paris, 2011 
A tabela abaixo permite perceber a variação do número total de vítimas da fome no decorrer do século $\mathrm{XX}^{168}$.

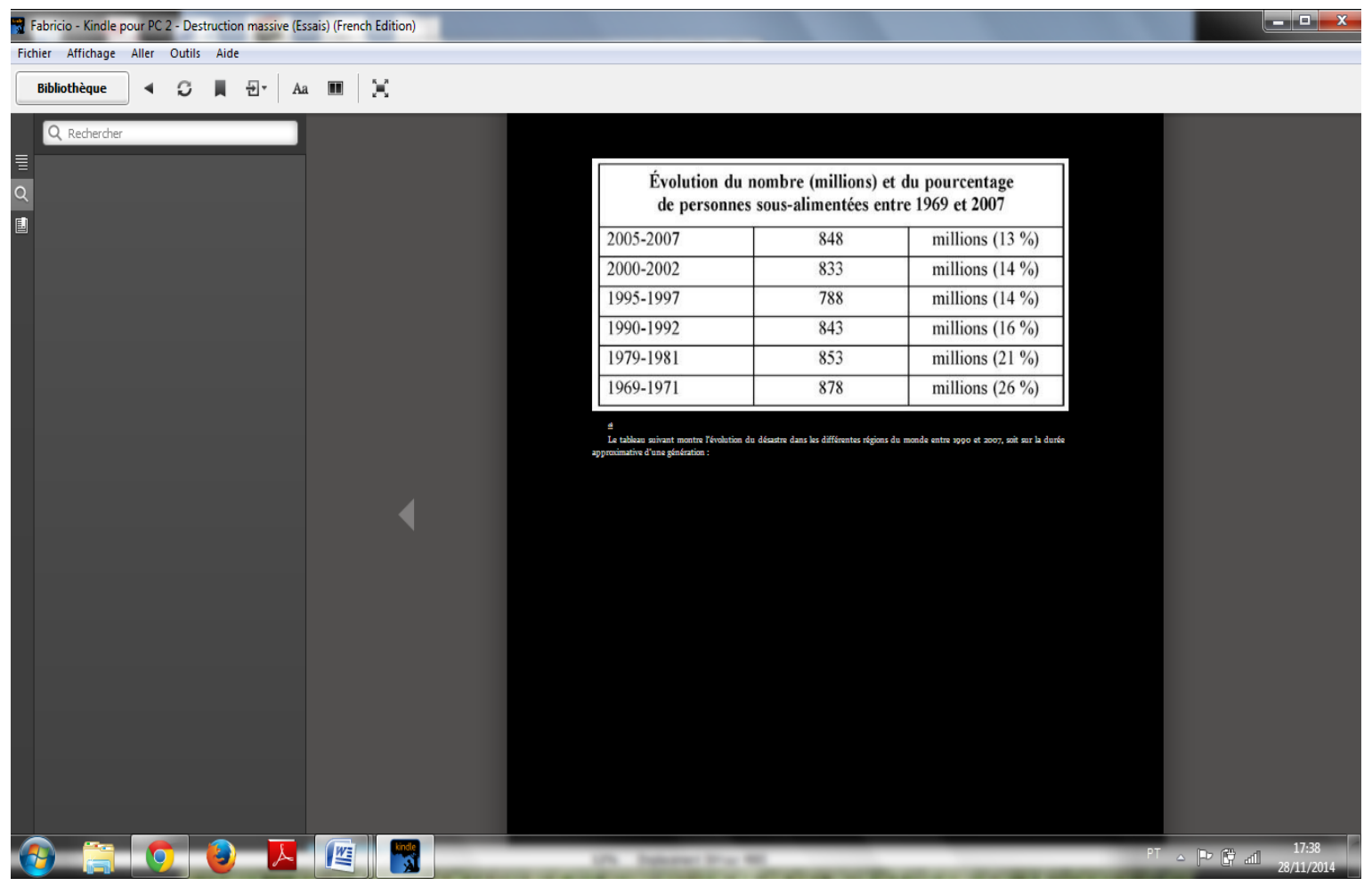

168 Gráfico foi extraído do Relatório sobre a insegurança alimentar no mundo (Roma, FAO, 2010) in ZIEGLER, Jean. Destruição Massiva- Geopolítica da Fome. éditions du Seuil, Paris, 2011 


\subsection{1 - A CÚPULA MUNDIAL DA ALIMENTAÇÃO (1996)}

Não obstante a Declaração Universal de Direitos Humanos situar todos os direitos humanos em um mesmo nível, a atenção prestada no plano internacional aos direitos econômicos, sociais e culturais foi sumamente escassa por vários decênios. Uma série de importantes conferências mundiais imprimiram um impulso considerável ao reconhecimento e à promoção desses direitos: a Cúpula Mundial em favor da Infância de 1990, a Conferência das Nações Unidas sobre o Meio Ambiente e o Desenvolvimento de 1992, a Conferência Internacional de Direitos Humanos de 1993, a Conferência Internacional sobre a População e o desenvolvimento de 1994, a Cúpula Mundial sobre o Desenvolvimento Social de 1995, a Quarta Conferência Mundial sobre a Mulher de 1995 e a Segunda Conferência das Nações Unidas sobre os Assentamentos Humanos de 1996. Essas conferências representaram ritos em um processo com vistas a uma melhor compreensão da relação entre o direitos humanos e o desenvolvimento, e um reconhecimento de que os direitos econômicos, sociais e culturais são tão indispensáveis quanto os civis e políticos. ${ }^{169}$.

A Declaração Universal data de 1948 e a Conferência Mundial da Alimentação ocorreu em 1996. Dessa forma, levou quase meio século para que fosse produzido o primeiro plano de ação coerente com a intenção de tornar o direito à alimentação uma realidade. Um caso similar é aquele da Convenção das Nações Unidas sobre a Prevenção e a Repressão do Crime de Genocídio, que data de 1948, enquanto o Estatuto de Roma do Tribunal Penal Internacional, responsável por aplicá-la, foi adotado somente em $1998^{170}$. (gn)

O progresso mais importante no que diz respeito o direito à alimentação foi consequência da Cúpula Mundial sobre a Alimentação, realizada em 1996 na sede da FAO com a participação de 180 nações.

Tendo em conta que a Declaração de Roma sobre a Segurança Alimentar Mundial e o Plano de Ação da Conferência Mundial sobre a Alimentação foram aprovados pela Cúpula e, portanto, por todos os dirigentes do mundo, os compromissos neles contraídos são considerados de primordial importância jurídica, política e moral para a comunidade mundial.

\footnotetext{
${ }^{169}$ ibidem.p.10.

${ }^{170}$ ZIEGLER, Jean. The fight for the Right to Food: Lessons Learned, Palgrave Macmillan, 2011. ISBN:9780-230-28464-7.p.5.
} 


\subsection{2 - A DECLARAÇÃO DE ROMA SOBRE A SEGURANÇA ALIMENTAR E SEU PLANO DE AÇÃO}

Os governos reunidos em Roma declararam que consideravam intolerável e inaceitável que mais de 800 milhões de pessoas em todo o mundo, em particular nos países em desenvolvimento, não dispusessem de alimentos suficientes para satisfazerem suas necessidades nutricionais básicas. Reconheceram que esse estado das coisas não era consequência da falta de fornecimento de alimentos. Observaram que esses fornecimentos haviam aumentado consideravelmente e que as limitações radicavam no acesso aos alimentos. Os problemas residiam na contínua insuficiência dos ingressos familiares para comprar alimentos, assim como na instabilidade da oferta e da demanda e nas catástrofes naturais e de origem humana. ${ }^{171}$

Assinalaram também que os problemas da fome e da insegurança alimentar tinham dimensões mundiais, e que era provável que persistissem e, inclusive, se agravassem dramaticamente em algumas regiões se não se adotasse com urgência uma ação decidida e concertada, especialmente dados o crescimento previsto da população mundial e a tensão a que estavam submetidos os recursos naturais. Os dirigentes do mundo prometeram, portanto, consagrar sua vontade política e sua dedicação comum e nacional a conseguir a segurança alimentar para todos e a realizar um esforço constante para erradicar a fome de todos os países, com o objetivo imediato de reduzir o número de pessoas desnutridas à metade do nível de 1996 não mais tarde do que o ano de 2015.

A Declaração de Roma definiu sete compromissos que formam a base para alcançar a segurança alimentar sustentável para todos. Os governos participantes da conferência comprometeram-se a implementar, monitorar e seguir o Plano de Ação da Conferência em todos os níveis e em cooperação com a comunidade internacional (compromisso 7). Na Declaração de Roma, os governos reafirmaram o direito de todos a terem acesso à alimentação segura e nutritiva, consistente com o direito à alimentação adequada e o direito fundamental de todos estarem livres da fome. A Declaração também deu um mandato específico para o Alto Comissariado para os Direitos Humanos ${ }^{172}$ de

${ }^{171}$ EIDE, Asbjorn. E/CN.4/Sub.2/1999/12 - O direito a uma alimentação adequada e a não padecer de fome.Estudo atualizado sobre o direito à alimentação apresentado pelo sr. Asbjorn Eide em cumprimento da decisão 1998/106 da Subcomissão de Prevenção de Discriminações e Proteção da Minorias.p.12

172 O Alto Comissariado das Nações Unidas para os Direitos Humanos (OHCHR) é o principal órgão da ONU encarregado de promover e de proteger os direitos humanos. Ele foi criado pela Resolução 48/141 da 
melhor definir os direitos relacionados à alimentação e propor modos de implementar e de efetivá-lo.(gn)

O Plano de Ação traça os objetivos e ações relevantes para a implementação prática dos sete compromissos. Os cinco objetivos seguintes foram definidos no Plano de Ação:

Objetivo 7.1: Adotar medidas dentro do marco nacional de cada país com vista a melhorar a segurança alimentar e permitir o cumprimento dos compromissos contraídos no Plano de Ação da Conferência Mundial sobre a Alimentação;

Objetivo 7.2: Melhorar a cooperação subregional, regional e internacional, e mobilizar os recursos disponíveis, para apoiar os esforços nacionais com o objetivo de conseguir o mais rápido possível uma segurança alimentar sustentável no mundo;

Objetivo 7.3: Vigiar ativamente a aplicação do Plano de Ação da Conferência Mundial sobre a Alimentação;

Objetivo 7.4: Esclarecer o conteúdo do direito a uma alimentação suficiente e do direito fundamental de todas as pessoas a não padecerem de fome, como se declara no PIDESC e em outros instrumentos internacionais e regionais pertinentes, e prestar atencão especial atencão à aplicacão e à realizacão plena e progressiva deste direito como meio de conseguir a seguranca alimentar de todos. (gn)

Objetivo 7.5: Compartilhar as responsabilidades de consecução da segurança alimentar para todos, de maneira que a aplicação do Plano de Ação da Cúpula Mundial sobre a Alimentação se leve a cabo ao nível mais baixo possível em que possa conseguir da melhor forma seu objetivo.

Assembleia Geral da ONU de 1993, com base na recomendação da Conferência Mundial sobre Direitos Humanos de Viena (1993).

O OHCHR é parte da estrutura da Secretaria Geral da ONU e inclui, entre suas competências específicas, o apoio aos demais órgãos da ONU envolvidos com a matéria, abrangendo a coordenação das atividades que desenvolvem e o esforço para que todas as áreas das Nações Unidas incluam considerações relativas à proteção da dignidade humana no tratamento dos temas de sua competência.

As dimensões do trabalho do Alto Comissariado são três: a contribuição para a elaboração de novas normas de direitos humanos, o monitoramento de sua observância pelos Estados e a sua aplicação. in in PORTElA, Paulo Henrique Gonçalves. Direito Internacional Público e Privados, incluindo noções de direitos humanos e de direito comunitário. 3 ed. , editora juspodium. p.756 


\section{O objetivo 7.4 refere-se, pois, diretamente ao direito à alimentação.}

No Plano de Ação, pede-se que os governos, em associação com todos os participantes da sociedade civil, procedam com o seguinte ${ }^{173}$ :

a) Fazer todo o possível para aplicar as disposições do artículo 11 do PIDESC e as disposições pertinentes de outros instrumentos internacionais.

b) Instar os países que ainda não são partes do PIDESC a aderirem-no o mais rápido possível.

c) Convidar o Comitê de Direitos Humanos, Sociais e Culturais a prestar atenção especial ao Plano de Ação no marco de suas atividades e a continuar vigiando a aplicação das medidas concretas que se estipulam no artigo 11 do Pacto.

d) Convidar os órgãos pertinentes criados em razão de tratados e os organismos especializados competentes das Nações Unidas a estudarem o modo como poderiam contribuir com a aplicação posterior do direito à alimentação, no marco do seguimento coordenado pelo Sistema das Nações Unidas das recomendações das principais conferências e cúpulas internacionais da ONU, inclusive a Conferência Mundial sobre Direitos Humanos, dentro dos limites de seus mandatos. (gn)

e) Convidar o Alto Comissariado das Nações Unidas para os Direitos Humanos a definir melhor, em consulta com os órgãos pertinentes criados em razão de tratados e em colaboração com os organismos especializados e programas pertinentes do sistema das Nações Unidas e com os mecanismos intergovernamentais apropriados, os direitos relacionados com a alimentação que se mencionam no artigo 11 do Pacto, bem como propor formas de aplicar e de realizar esses direitos como meio de realizar os compromissos e objetivos da Cúpula Mundial sobre a Alimentação, tendo em conta a possibilidade de estabelecer diretrizes voluntárias encaminhadas a alcançar a segurança alimentar para todos. (gn)

173 EIDE, Asbjorn. E/CN.4/Sub.2/1999/12 - O direito a uma alimentação adequada e a não padecer de fome.Estudo atualizado sobre o direito à alimentação apresentado pelo sr. Asbjorn Eide em cumprimento da decisão 1998/106 da Subcomissão de Prevenção de Discriminações e Proteção da Minorias.p.13. 


\section{5 - O COMITÊ DE DIREITOS ECONÔMICOS, SOCIAIS}

\section{E CULTURAIS E SEU MODELO DOUTRINÁRIO: AS OBSERVAÇÕES GERAIS \# 12- E/C.12/1999/5}

Para a aplicação do objetivo 7.4 do Plano de Ação da Cúpula Mundial sobre Alimentação de 1996, o Alto Comissariado para os Direitos Humanos firmou um memorando de entendimento com a FAO, bem como adotou outras várias medidas para iniciar a cooperação com organismos pertinentes e órgãos criados em razão de tratados. Isso significou, em termos institucionais de autoridades, que houve uma comunicação entre agências especializadas, conforme artigo 63.2 Carta da ONU ${ }^{174}$. Enquanto o Alto Comissariado responde à Assembleia Geral, a FAO responde ao ECOSOC e à Assembleia Geral.

O Comitê de Direitos Humanos, Sociais e Culturais, órgão do PIDESC, celebrou, no dia 1 de dezembro de 1997, um dia de debate geral sobre o direito à alimentação, ao qual assistiram a Alta Comissária e especialistas convidados. No dia seguinte, seguiu-se a primeira consulta de especialistas sobre esse tema. Entre outras coisas, recomendou-se que o Comitê de Direitos Econômicos, Sociais e Culturais preparasse e aprovasse uma observação geral sobre o direito à alimentação, o que este se dispôs a fazer.

Em novembro de 1998, o Escritório do Alto Comissariado para os Direitos Humanos organizou uma segunda consulta, copatrocinada pela FAO em Roma. Em abril de 1999, a Alta Comissária informou à Comissão de Direitos Humanos (sob competência do ECOSOC: 1946-2006) sobre as conclusões dessa consulta ${ }^{175}$.

O rito mais importante até a data do processo de acompanhamento foi a preparação e a aprovação, em 12 de maio de 1999, pelo Comitê de Direitos Econômicos, Sociais e Culturais em seu $20^{\circ}$ período de sessões, da Observação Geral 12

\footnotetext{
${ }^{174}$ Artigo 63.2 Carta da ONU- O Conselho Econômico e Social poderá coordenar as atividades das entidades especializadas, por meio de consultas e recomendações às mesmas e de recomendações à Assembleia Geral e aos membros das Nações Unidas.

${ }^{175}$ EIDE, Asbjorn. E/CN.4/Sub.2/1999/12 - O direito a uma alimentação adequada e a não padecer de fome. Estudo atualizado sobre o direito à alimentação apresentado pelo sr. Asbjorn Eide em cumprimento da decisão 1998/106 da Subcomissão de Prevenção de Discriminações e Proteção da Minorias.p.14.
} 
(E/C.12/1999/5) sobre o direito à alimentação adequada (artigo 11 PIDESC) ${ }^{176}$.

Do compromisso da Cúpula Mundial sobre Alimentação (1996) para uma melhor definição do direito à alimentação consagrado no artigo 11, houve uma resposta institucional, cujo processo foi descrito acima, que culminou na aprovação da Observação Geral 12 pelo Comitê de Direitos Econômicos, Sociais e Culturais. Esse foi um passo da máxima importância no processo com vistas ao esclarecimento do conteúdo do direito à alimentação e das medidas que deveriam ser adotadas para sua realização. Tendo em conta de que se trata da interpretação do órgão criado em razão de um tratado, cuja responsabilidade é a de vigiar a aplicação pelos Estados-partes do direito à alimentação adequada, a Observação Geral 12 representa o documento de maior peso em relação ao direito à alimentação. O resultado líquido dessas atividades realizadas desde a Cúpula Mundial sobre a Alimentação (1996) foi o de ter esclarecido o conteúdo do direito à alimentação e à nutrição; ter-se difundido a consciência da importância de se adotar medidas mais decididas para pôr em prática o direito à alimentação ${ }^{177}$.

176 Desde, pelo menos, 1983, a Subcomissão para a Prevenção da Discriminação e a Proteção de Minorias tinha apontado um Relator Especial para o direito à alimentação. Um relatório inicial do Relator em 1984 (E/CN.4/SUB.2/1984/22 e Anexos.1 e 2), foi seguido por um relatório final submetido em 1987.

Depois de muitos anos de trabalho, outro relatório ínterim (E/CN.4/SUB.2/1998/9) atualizando aqueles estudos foi apresentado à Subcomissão para a Promoção e a Proteção dos Direitos Humanos em sua Quinquagésima Sessão. Em agosto de 1999, o Relator Especial, Asbjorn Eide, apresentou um relatório final atualizado (E/CN.4/SUB.2/1999/12) - o qual, segundo ele, deve ser lido em conjunto com sua atualização de 1998 -, sendo adotado pela Subcomissão de Promoção e Proteção de Direitos Humanos. in ZIEGLER, Jean. The fight for the Right to Food: Lessons Learned, Palgrave Macmillan, 2011. ISBN:978-0-230-28464-7.p.10. ${ }^{177}$ EIDE, Asbjorn. E/CN.4/Sub.2/1999/12.p.15 sgts 


\section{1 - O DIREITO À ALIMENTAÇÃO E A DIGNIDADE}

\section{HUMANA}

O artigo 11 do PIDESC centra-se nas dimensões mais amplas do direito à alimentação. $O$ direito à alimentação forma parte do direito mais amplo a um nível de vida adequado ${ }^{178}$. O direito a um nível de vida adequado - ou à subsistência - sintetiza a preocupação central de todos os direitos econômicos e sociais, que é o de integrar todas as pessoas em uma sociedade mais humana. O propósito fundamental da promoção do direito a uma alimentação adequada é o de conseguir o bem-estar nutricional de cada criança, mulher e homem. O estado nutricional do ser humano está determinado por, pelo menos, três conjuntos importantes de condições que se inter-relacionam com a alimentacão, com a saúde e a assistência, e com a educacão como dimensão transversal. A alimentação, por si, não é suficiente para assegurar uma boa nutrição do indivíduo. O direito a uma alimentação adequada é um componente necessário, porém insuficiente por si só, do direito a uma nutrição adequada. A plena realização desse segundo direito depende, também, dos êxitos paralelos nos setores da saúde, da assistência às pessoas vulneráveis e da educação ${ }^{179}$.

O princípio básico do sistema de direitos humanos é o de todos nascerem livres e iguais em dignidade e em direitos e [...] deverem comportar-se fraternalmente uns com os outros (artigo 1 DUDH1948). O Comitê afirma em sua observação geral (§4) que

o direito a uma alimentação adequada está inseparavelmente vinculado à dignidade inerente da pessoa humana e é indispensável para o gozo de outros direitos humanos consagrados na Carta Internacional de Direitos Humanos. Ele é também inseparável da justiça social, pois requer a adoção de políticas econômicas, ambientais e sociais adequadas, nos planos nacional e internacional, orientadas para a erradicação da pobreza e para o gozo de todos os direitos humanos por todos.

\footnotetext{
${ }^{178}$ O direito a um nível de vida adequado está consagrado no artigo 25 da Declaração Universal dos Direitos Humanos, no artigo 11.1 do PIDESC e no artigo 27 da Convenção sobre os Direitos das Crianças.

179 Os instrumentos mais recentes, em particular a Convenção sobre os Direitos das Crianças, reconhecem este direito mais amplo à nutrição, assim como sua característica transversal em relação aos muitos outros direitos, incluídos os civis e políticos.
} 


\section{2 - OS PRINCIPAIS ASPECTOS DO DIREITO À}

ALIMENTAÇÃO

Na Observação Geral \# 12, o Comitê DESC expressa o conteúdo básico do direito à alimentação adequada, nos seguintes termos (§6):

$\mathrm{O}$ direito à uma alimentação adequada é realizado, quando todo homem, mulher e criança, só ou em comunhão com outros, tem acesso físico e econômico em qualquer momento à alimentação adequada ou aos meios para sua aquisição. O direito à alimentação adequada não deverá ser interpretado de modo restritivo ou restrito, que o equaciona ao mínimo necessário de calorias, de proteínas e outros nutrientes específicos. $\mathrm{O}$ direito à alimentação adequada deverá ser realizado progressivamente, porém os Estados têm a obrigação central de realizar todas as ações necessárias para mitigar e aliviar a fome... mesmo em ocasiões de desastres naturais.

Em continuação, figuram algumas considerações do Comitê DESC em sua observação geral 12 sobre a estrutura e os principais aspectos do conteúdo do direito à alimentação, quais sejam: a dignidade, a adequação e sustentabilidade da disponibilidade de alimentos, e o acesso a eles.

O conceito de adequação vem determinado, em boa medida, pelas condições sociais, econômicas, culturais, climáticas, ecológicas, mas há também alguns elementos básicos que se aplicam em todas as circunstâncias. Ao esclarecer o conteúdo do termo "adequado", a observação geral ( $\$ 7$ a 11) expõe, com certo detalhe, o significado dos subconceitos de necessidades alimentares, sem substâncias nocivas e aceitáveis para uma cultura ou para consumidores determinados.

O conceito de "sustentabilidade" entranha os conceitos de disponibilidade e de acessibilidade de longo prazo, e está intimamente vinculado ao conceito de alimentação adequada ou de segurança alimentar, o que implica a possibilidade de acesso aos alimentos por parte das gerações presentes e futuras. 
O conceito de sustentabilidade é explicado em termos de disponibilidade e acessibilidade - física e econômica - para diferentes grupos de pessoas ( $\$ 12$ e 13). A gestão sustentável dos recursos naturais deve ser feita de forma que se garanta a disponibilidade dos alimentos suficientes não só para as gerações presentes, mas também para as futuras ${ }^{180}$.

A disponibilidade compreende a possibilidade de a pessoa alimentar-se diretamente do que a terra ou outros recursos naturais produzem, ou por intermédio de um sistema eficaz de distribuição, de processamento e de comercialização, que permita transferir os alimentos desde o lugar de produção até onde seja necessário segundo a demanda. Todas as pessoas devem ter acesso, tanto em termos econômicos quanto físicos, à alimentos suficientes e adequados. A acessibilidade implica que os custos associados à aquisição dos alimentos necessários para um regime alimentício adequado devem estar a um nível tal que não ponham em perigo a provisão e a satisfação de outras necessidades básicas $^{181}$.

Esse grau de detalhamento é muito útil, porque oferece a oportunidade de os Estados-partes informarem, de maneira mais pormenorizada, sobre a realização do direito à uma alimentação adequada, que só alcança seu pleno significado, quando a "alimentação" engloba também o desfrute de outros direitos que, em última instância, determinam a acessibilidade e constituem um verdadeiro veículo de saúde nutricional ${ }^{182}$.

A existência do direito humano à alimentação deu origem às obrigações para os Estados.

A índole das obrigações jurídicas dos Estados-partes é enunciada no artigo 2 do PIDESC e foi tratada na Observação Geral \#3 (1990) do Comitê (DESC). A principal obrigação é a de adotar medidas para lograr progressivamente o pleno exercício do direito à uma alimentação adequada. A realização progressiva impõe a obrigação de avançar o mais rapidamente possível para que o objetivo seja alcançado. Cada um dos Estados-partes se compromete a adotar medidas para garantir que toda pessoa que se encontre sob sua jurisdição tenha acesso mínimo a alimentos essenciais, suficientes,

\footnotetext{
${ }^{180}$ FAO, Cuaderno de Trabajo sobre el derecho a la alimentación 1. El derecho a la alimentación en el marco internacional de los derechos humanos y en las constituciones. 2013. p.5.

${ }^{181}$ ibidem.p.5.

${ }^{182}$ EIDE, Asbjorn. E/CN.4/Sub.2/1999/12.p.17.
} 
inócuos e nutritivamente adequados para protegê-la da fome ${ }^{183}$.

Os direitos econômicos e sociais, da mesma forma que todos os demais direitos humanos, são violados com frequência, porém tem havido certa controvérsia com respeito à definição sobre o que constitui uma violação desses direitos, incluindo o direito à alimentação. Esse assunto é tratado na Observação Geral \#12 (§17 a 20).

O PIDESC é violado, quando um Estado não garante a satisfação de, pelo menos, o nível mínimo essencial necessário para estar protegido contra a fome. As limitações de recursos não eximem da responsabilidade o Governo, que deve demonstrar que tem feito todo o possível para utilizar todos os recursos de que dispõe com vistas a cumprir, de modo prioritário, essas obrigações mínimas. Toda discriminação no acesso aos alimentos, assim como aos meios e aos direitos para obtê-los constituem uma violação do Pacto. As violações podem ser produzidas por atos realizados diretamente pelos Estados ou por outras entidades insuficientemente reguladas pelos Estados. Os atores não estatais também têm responsabilidades e o Estado deve criar um meio que facilite o exercício dessas responsabilidades. No que diz respeito ao setor empresarial privado, seja nacional ou transnacional, um código de conduta deveria ser aprovado e usado ${ }^{184}$.

${ }^{183}$ Observação Geral \#12 - O direito à uma alimentação adequada (artigo 11 §14).

${ }^{184}$ EIDE, Asbjorn. E/CN.4/Sub.2/1999/12.p.18 


\section{3 - AS OBRIGAÇÕES DOS ESTADOS EM RELAÇÃO AO DIREITO À ALIMENTAÇÃO}

Asbjorn Eide, em seu memorável relatório sobre o direito à alimentação adequada, estabelece três obrigações principais que podem ser parafraseadas a seguir: respeitar, proteger e satisfazer o direito à alimentacão.

Segundo o próprio autor ${ }^{185}$ :

Meu estudo de 1987 foi realizado com a intenção de contribuir para o esclarecimento da natureza e dos níveis de obrigações dos Estados em relação aos direitos econômicos e sociais. Com base em meu trabalho anterior, introduzi um marco analítico que permite avaliar as obrigações dos Estados em três níveis: a obrigação de respeitar, a obrigação de proteger e a obrigação de facilitar e satisfazer os direitos humanos. Esse marco analítico resultou-se bem útil e tem sido amplamente usado desde então.

Esses três níveis de obrigações foram, posteriormente, definidos pelo Comitê DESC em sua Observação Geral \# 12 sobre o direito à alimentação adequada, antes de terem sido aceitos pelos Estados nas Diretrizes Voluntárias sobre o Direito à Alimentação de $2004^{186}$. (gn)

${ }^{185}$ EIDE, Asbjorn. E/CN.4/Sub.2/1999/12.p.17.

${ }^{186}$ ZIEGLER, Jean. The fight for the Right to Food: Lessons Learned, Palgrave Macmillan, 2011. ISBN:9780-230-28464-7.p.18. 


\subsection{1 - A OBRIGAÇÃO DE RESPEITAR O DIREITO À}

ALIMENTAÇÃ $\mathbf{O}^{187}$

A obrigação de respeitar significa que um Governo não deve, arbitrariamente, tirar o direito à alimentação das pessoas nem dificultar o acesso à comida delas. A obrigação de respeitar o direito à alimentação é, efetivamente, uma obrigação negativa, pois essa obrigação acarreta limites ao exercício do poder estatal que pode ameaçar o acesso existente das pessoas à alimentação. Por fim, a obrigação de respeitar exige que os Estados não adotem medidas que tenham como resultado impedir, limitar ou privar as pessoas da possibilidade de alimentar-se por seus próprios meios.

As violações do dever de respeitar ocorreriam, por exemplo, se um Governo arbitrariamente despejasse ou desalojasse pessoas de suas terras, especialmente se a terra for o meio de subsistência primário delas; se um Governo tirasse as provisões de segurança social sem estar certo de que as pessoas vulneráveis terem modos alternativos de se alimentarem; ou se um Governo introduzisse, deliberadamente, substâncias tóxicas na cadeia alimentar, uma vez que o direito à alimentação implica acesso à comida que seja "livre de substâncias adversas".Em situações de conflitos armados, essa obrigação de respeitar significaria que as tropas de um Governo não devem destruir recursos produtivos nem devem bloquear, atrasar ou desviar ajuda humanitária para as populações civis.

${ }^{187}$ ibidem.p.18 e sgts. 


\subsection{2 - A OBRIGAÇÃO DE PROTEGER O DIREITO À}

ALIMENTAÇÃO.

A obrigação de proteger significa que o Governo tem de aprovar e aplicar leis que impeçam pessoas ou organizações poderosas de violarem o direito à alimentação. A obrigação de proteger requer que os Estados regulamentem atores não estatais, incluindo corporações ou indivíduos que possam ameaçar o direito à alimentação de outras pessoas. Um governo deve também estabelecer órgãos para investigar e prover remédios efetivos, incluindo acesso à justiça, caso esse direito seja violado.

Por exemplo, se um Governo não intervém, quando um indivíduo poderoso despeja as pessoas de suas terras, então, o Governo viola a obrigação de proteger o direito à alimentação. Um Governo também falharia em proteger o direito à alimentação, se ele restasse inerte caso uma companhia poluísse o fornecimento de água de uma comunidade.

Para proteger o direito à alimentação, o Governo deve também agir, caso o acesso à comida fosse negado com base no gênero, raça ou outras formas de discriminação. Ele também pode, por exemplo, introduzir leis que protejam os consumidores contra produtos alimentares nocivos ou contra modos de produção insustentáveis. A proteção do direito à alimentação poderia incluir a introdução de rótulos nos alimentos ou legislação sobre o uso de pesticidas ou de alimentos geneticamente modificados. 


\subsection{3 - A OBRIGAÇÃO DE SATISFAZER O DIREITO À} ALIMENTAÇÃO

A obrigação de satisfazer (facilitar e prover) o direito à alimentação significa que um Governo deve adotar medidas positivas para (i) facilitar o exercício do direito à alimentação, aplicando políticas e programas que melhorem a capacidade da população para se alimentarem por si mesmas; (ii) tornar efetivo o exercício desse direito, fornecendo alimentos diretamente para as pessoas ou grupos que, por razões que estão além de seu controle, não podem alimentar-se por seus próprios meios, garantindo o mínimo para ninguém padecer de fome no país; (iii) promover o conhecimento pleno dos direitos humanos - em concreto, do direito à alimentação - tanto por parte dos agentes e funcionários dependentes do Estado quanto por parte do setor privado ${ }^{188}$.

A Observação Geral \#12 (\$15) resume essa obrigação da seguinte maneira:

...quando um indivíduo ou grupo está incapacitado, por razões além do controle deles, de gozar do direito à alimentação adequada de acordo com os meios à disposição deles, os Estados têm a obrigação de prover o direito à alimentação diretamente.

A obrigação de satisfazer é uma obrigação positiva, uma vez que isso significa que um Governo tem de procurar identificar ativamente os grupos vulneráveis e implementar políticas para melhorar o acesso dessas pessoas à alimentação adequada, bem como a capacidade delas de se alimentarem. Essa obrigação de realizar (facilitar) poderia significar o incremento das perspectivas de empregos por meio da introdução de um programa de reforma agrária para os grupos sem terras ou a promoção de oportunidades de empregos alternativas. Essa obrigação poderia, também, incluir programas alimentares em escolas de modo a melhorar a nutrição da criança.

\footnotetext{
${ }^{188}$ FAO, Cuaderno de Trabajo sobre el derecho a la alimentación 1. El derecho a la alimentación en el marco internacional de los derechos humanos y en las constituciones. 2013.p.7
} 
A obrigação de prover vai além da obrigação de facilitar, mas somente tem efeito, quando a segurança alimentar das pessoas estiver ameaçada por razões que estão além do controle delas. Como um último recurso, assistência direta pode ser fornecida por intermédio de redes de segurança, como os programas de vale alimentação ou provisões de segurança social para assegurar a erradicação da fome. Esse apoio deve ser provido como uma questão de direito, ao invés de caridade, de modo a garantir-se a dignidade humana.

Um Governo violaria suas obrigações de satisfazer o direito à alimentação, se ele deixasse as pessoas passarem fome, quando elas se encontrassem desesperadamente necessitadas e não tivessem outro modo de conseguir ajuda. Um apelo do Estado por ajuda humanitária, quando ele próprio não tiver condições de garantir o direito à alimentação da população, também recai sob essa terceira obrigação. Os Estados que não fazem esse apelo, em razão de negligência ou de orgulho nacional inapropriado, ou que deliberadamente atrasam esses chamados, estão violando suas obrigações, assim como no caso da Etiópia sob a ditadura de Haile Mengistu no início dos anos 1980. 


\subsection{4 - OBRIGAÇÃO DE COOPERAR E DE PRESTAR ASSISTÊNCIA $^{189}$}

Animados pelo espírito do artigo 56 da Carta das Nações Unidas, pela Declaração de Roma sobre Segurança Alimentar Mundial (1996), pelas disposições do parágrafo 2 do artigo 2, pelo artigo 11, pelo parágrafo 2 do artigo 15 e pelo artigo 23 do PIDESC, os Estados-partes devem reconhecer a função fundamental que corresponde à cooperação internacional e devem reafirmar sua decisão de adotar, em colaboração com outros Estados ou em separado, medidas que assegurem a plena realização do direito à uma alimentação adequada.

Tanto a cooperação internacional quanto a ajuda internacional são fundamentais para a realização do direito de toda pessoa à uma alimentação adequada. Os Estados devem abster-se de impor medidas que possam interferir na possibilidade de outro Estado de realizar o direito à alimentação de seus habitantes. Em nenhum caso, os alimentos serão usados como mecanismo de pressão política, nem se condicionará a ajuda humanitária a certas questões econômicas ou políticas, nem se estabelecerão bloqueios comerciais que impeçam que o alimento chegue a outro país, nem se imporão sanções que afetem o abastecimento da população.

A obrigação de cooperar também implica que os Estados, cujos recursos sejam extremamente limitados, devem solicitar assistência internacional, quando for preciso para evitar que se produza uma situação de fome extrema ${ }^{190}$.

${ }^{189}$ Comitê DESC, Observação Geral \#12. E/C.12/1999/5, §36,37

${ }^{190}$ FAO, Cuaderno de Trabajo sobre el derecho a la alimentación 1. El derecho a la alimentación en el marco internacional de los derechos humanos y en las constituciones. 2013.p.7 


\subsection{5 - A OBRIGAÇÃO DE PROVER O MÍNIMO BÁSICO DE SUBSISTÊNCIA}

Há uma evidente obrigação mínima e central sobre todos os Estados de proverem, pelo menos, um nível essencial mínimo de direitos econômicos, sociais e culturais, incluindo o direito à alimentação, independentemente da limitação de realização progressiva. Esse conceito de realização progressiva não pode ser usado para justificar persistentes injustiças e desigualdades. A realização progressiva requer que os Governos tomem medidas imediatas para melhorar, de forma contínua, a capacidade das pessoas alimentarem-se e, por fim, erradicarem a fome. De acordo com a Observação Geral \#12, a limitação da realização progressiva reside nos seguintes termos firmados pelo parágrafo 6:

...os Estados têm a obrigação central de realizar todas as ações necessárias para mitigar e aliviar a fome... mesmo em ocasiões de desastres naturais.

Essa obrigação mínima essencial é uma obrigação imediata, apesar dela ainda estar sujeita aos recursos disponíveis. Conforme o Comitê esclareceu no parágrafo 17 da Observação Geral \#12:

...Ao determinar quais medidas ou omissões constituem uma violação ao direito à alimentação, é importante distinguir entre a falta de capacidade e a falta de vontade de um Estado para cumprir suas obrigações. No caso de um Estado-parte aduzir que a limitação de seus recursos o impediu de facilitar o acesso à alimentação àquelas pessoas que não são capazes de obter comida por si mesmas, o Estado tem de demonstrar que fez todos os esforços possíveis para usar todos os recursos de que dispõe com o fim de cumprir, de forma prioritária, essas obrigações mínimas. Essa obrigação emana do parágrafo 1 do artigo 2 do Pacto, segundo o qual se obriga a cada Estado-parte tomar as medidas necessárias até o máximo de recursos que disponha, conforme assinalou anteriormente o Comitê em sua Observação Geral \#3, parágrafo 10.(gn) 


\subsection{6 - A OBRIGAÇÃO DE NÃO REGRESSÃO}

A noção de realização progressiva do direito à alimentação também implica o "princípio de não regressão", o que significa que os Governos não devem adotar políticas regressivas que levam à deterioração no acesso à comida. O que os Governos devem fazer, portanto, é adotarem um plano de ação com metas concretas e com cronogramas estabelecidos, bem como monitorarem o progresso no decorrer do tempo para mensurar a realização progressiva.

Os esforços nacionais para monitorarem a Meta 1 do desenvolvimento do Milênio sobre erradicação da fome proporciona um passo importante nessa direção, entretanto os Governos devem também ser demandados para explicarem e prestarem contas com respeito a quaisquer regressões na realização do direito à alimentação. 


\subsection{7 - A OBRIGAÇÃO DE NÃO DISCRIMINAÇÃO}

De acordo com o direito internacional, a proibição da discriminação não está sujeita à limitação da realização progressiva. A obrigação de não discriminar é um dever imediato, e a discriminação no acesso à alimentação com base na raça, cor, sexo, língua, religião, opinião política, origem social e nacional, propriedade, nascimento ou outra condição, conforme definido no artigo 2, parágrafo 2 do PIDESC, não pode ser justificada em quaisquer circunstâncias, incluindo baixos níveis de recursos. Isso significa que o Estado deve garantir que os recursos sejam compartilhados de forma equitativa, independentemente do nível dos recursos, e que grupos específicos não sejam discriminados na distribuição dos recursos pelo Estado. 


\section{6 - O MODELO HERMENÊUTICO DO CONSELHO DE DIREITOS HUMANOS: RELATORIA ESPECIAL DO DIREITO ̀̀ ALIMENTAÇÃO}

Desde 1979, mecanismos especiais têm sido criados pelas Nações Unidas para examinar as situações de países específicos ou temas com a perspectiva dos direitos humanos. A Comissão de Direitos Humanos das Nações Unidas, substituída pelo Conselho de Direitos Humanos em Junho de 2006, têm mandatado especialistas para estudarem temas específicos de direitos humanos. Esses especialistas constituem o que é conhecido como os mandatos ou mecanismos ou sistemas de procedimentos especiais dos direitos humanos estabelecidos pelo Conselho, para fazer frente a situações concretas nos países ou a questões temáticas em todo o mundo.

O Relator Especial é um especialista independente nomeado pelo Conselho de Direitos Humanos, para examinar e apresentar relatório periódicos a respeito da situação de um país ou de um assunto específico de direitos humanos ${ }^{191}$ ao Conselho de Direitos Humanos e à Assembleia das Nações Unidas. Atualmente há 36 mandatos temáticos e 13 mandatos por país ${ }^{192}$.

Dentro da crescente preocupação que se foi produzindo com respeito ao direito à alimentação ao longo da década de 1990, destaca-se a criação do mandato do Relator Especial para o Direito à Alimentação. Esse posto foi originariamente estabelecido na $56^{\text {a }}$ sessão da Comissão de Direitos Humanos em Abril de 2000 de acordo com a resolução 2000/10. Após a substituição da Comissão pelo Conselho de Direitos Humanos em Junho de 2006, o mandato foi aprovado e estendido pelo Conselho por meio de sua resolução 6/2 de 27 de Setembro de 2007. Entre 2000 e 2008, o posto ficou a cargo do Professor Jean Ziegler, da Suiça. De 2008 até Abril de 2014, o posto ficou a cargo do Professor Olivier De Schutter. Desde Junho de 2014, a Relatoria Especial para o Direito à Alimentação é ocupada pela sra. Hilal Elver, da Turquia.

A função do Relator Especial para o Direito à Alimentação é o de garantir que os Estados estejam cumprindo suas obrigações de respeitar, de proteger e de satisfazer o direito à alimentação de todas as pessoas. A Comissão de Direitos Humanos criou o posto

\footnotetext{
${ }^{191}$ http://www.ohchr.org/EN/Issues/Food/Pages/FoodIndex.aspx

${ }^{192}$ FAO, Cuaderno de Trabajo sobre el derecho a la alimentación 9. Quien es quien en el derecho a la alimentación. 2013.p.22.
} 
de Relator Especial para o Direito à Alimentação "para responder plenamente à necessidade de uma abordagem integrada e coordenada na proteção e na promoção do direito à alimentação" 193 .

O Relator Especial para o Direito à Alimentação implementa seu mandato mediante diferentes meios e atividades. Determinadas por diferentes resoluções do Conselho de Direitos Humanos as funções do mandato compreendem, entre outras, as seguintes ${ }^{194}$ :

i) O Relator Especial apresenta relatórios anuais para o Conselho de Direitos Humanos e para a Assembleia Geral sobre as atividades e os estudos assumidos com relação à implementação do mandato;

ii) O Relator Especial monitora a situação do direito à alimentação ao redor do mundo. $\mathrm{O}$ posto identifica tendências gerais relacionadas ao direito à alimentação e empreende visitas aos países, os quais fornecem ao Relator Especial informações em primeira mão a respeito da situação do direito à alimentação em países específicos;

iii) $\mathrm{O}$ Relator Especial transmite aos Estados e a outras partes consideradas casos alegados de violações do direito à alimentação;

iv) O Relator Especial promove a plena realização do direito à alimentação por intermédio do diálogo com relevantes atores, ao participar de seminários, conferências, encontros de especialistas.

Nos informes elaborados pela Relatoria Especial sobre o Direito à Alimentação, desde 2000, tem-se gerado um corpo de documentação muito interessante em que se desenvolve e se aprofunda o conceito de direito humano à alimentação, seus componentes e se analisam os diversos aspectos que incidem na realização do direito à $\operatorname{alimentação~}^{195}$.

As principais temáticas abordadas até o ano 2014 nos informes da Relatoria Especial sobre o Direito a alimentação são as seguintes: (a) $\mathrm{O}$ direito à alimentação na legislação internacional, (b) Medidas concretas para favorecer a introdução do direito à alimentação na legislação nacional; (c) Obstáculos para a realização do direito à alimentação, (d) Justiciabilidade do direito à alimentação, (e) Direito Humanitário

\footnotetext{
${ }^{193}$ Resolução 2001/25 de 20 de Abril da Comissão de Direitos Humanos, conforme foi aprovada pelo Conselho Econômico e Social em 2001. in ZIEGLER, Jean. The fight for the Right to Food: Lessons Learned, Palgrave Macmillan, 2011. ISBN:978-0-230-28464-7.p.386.

${ }^{194}$ http://www.ohchr.org/EN/Issues/Food/Pages/FoodIndex.aspx

${ }^{195}$ FAO, Cuaderno de Trabajo sobre el derecho a la alimentación 10.Formación sobre el derecho a la alimentación. 2013.p.21 e sgts.
} 
Internacional, (f) Água e direito à alimentação, (g) Comércio Internacional e Segurança Alimentar, (h) Soberania Alimentar, (i) Empresas Transnacionais e o direito à alimentação, (j) Defesa do direito à alimentação na era da globalização, (l) Direito à alimentação das crianças e dos refugiados da fome, (m) Crise alimentar e o direito à alimentação, (n) $\mathrm{O}$ papel do multilateralismo frente a crise alimentar, (o) Agroindústria e o direito à alimentação, (p) Aquisição e arrendamento de terra em larga escala (land grabbing), (q) Acesso à terra, reforma agrária e o direito à alimentação, (r) Gênero, direitos das mulheres e direito à alimentação, (s) Direito à alimentação nas populações indígenas, (t) Responsabilidades de organizações internacionais no direito à alimentação, (u) Políticas de sementes e o direito à alimentação, (v) Nexo entre agricultura, alimentação e saúde, (x) Impacto dos biocombustíveis no direito à alimentação, (z) Desertificação, degradação da terra e direito à alimentação. 


\section{7 - O MODELO HERMENÊUTICO DA FAO: CÚPULAS MUNDIAIS DA ALIMENTAÇÃO (2002,2009) E AS DIRETRIZES VOLUNTÁRIAS (2004)}

O direito humano à alimentação foi reconhecido na Declaração Universal de Direitos Humanos, aceito como obrigação vinculante por 160 Estados que ratificaram o Pacto Internacional de Direitos Econômicos, Sociais e Culturais, e reafirmado nas Cúpulas Mundiais sobre a Alimentação de 1996, 2002 e 2009.

\section{1 - A CÚPULA MUNDIAL DA ALIMENTAÇÃO: CINCO ANOS DEPOIS (CMA+5 - 2002)}

A Cúpula Mundial da Alimentação foi realizada em Roma, em Junho de 2002, para revisar o progresso com respeito aos compromissos acordados na Declaração de Roma, resultado de negociações diplomáticas na Cúpula de 1996. O compromisso central feito pelos governos em 1996 foi o de reduzir pela metade o número de vítimas da fome até 2015. Apesar desse compromisso, logo ficaria evidente que poucas ações tinham sido tomadas com respeito àqueles compromissos. A conclusão da Cúpula de 2002 dizia respeito à frustrante realidade de que poucos progressos tinham sido feitos com relação à meta. Cinco anos depois da Declaração de Roma (1996), ainda havia 815 milhões de famintos, de acordo com a $\mathrm{FAO}^{196}$.

A situação era ainda pior do que as estatísticas agregadas da FAO sugerem. Se o impressionante progresso da China fosse retirado das estatísticas, a fome mundial tinha aumentado desde 1996. De acordo com o Instituto Internacional de Pesquisa para Políticas Alimentares (IFPRI), o número de pessoas cronicamente má-nutridas ou em insegurança alimentar aumentou em 40 milhões nos anos 1990, descontando os progressos em segurança alimentar da China. Países em que o número de pessoas subnutridas aumentou incluíam o Afeganistão, Bangladesh, a República Democrática do Congo, Índia, Iraque, Kenia, a República Popular da Coréia, a República Unida da Tanzânia e Uganda. No continente africano, a situação na maioria dos países estava pior do que nos dez anos anteriores à $\mathrm{CMA}+5$. Na média, um terço de toda a população dos países subsaarianos

${ }^{196}$ FAO. O Estado da Insegurança Alimentar no Mundo, Roma, 2001. 
sofriam de fome crônica severa e desnutrição. A FAO relatou que, dos 91 países que informaram a implementação dos compromissos de 1996, "poucos se algum" poderiam ter alegado progresso substantivo na erradicação da fome ${ }^{197}$.

A Declaração Final da Cúpula (2002), adotada após três dias de intensas negociações, foi frustrante em termos de soluções propostas para a fome mundial, ao reconhecer que a meta de diminuir pela metade o número de famintos não seria atingida até 2015. Poucas soluções concretas foram propostas, exceto aquelas que estimulavam o livre comércio e o progresso biotecnológico. Esses últimas propostas, durante as negociações entre os representantes dos vários governos, revelaram-se muito controversas, por causa das diferentes avaliações em relação aos impactos potenciais dessas medidas em relação ao problema da fome ${ }^{198}$.

O conceito de direito à alimentação foi ardentemente debatido nas negociações para a Declaração Final. Havia pressão política de alguns governos para substituir o direito à alimentação pelo conceito de segurança alimentar, entretanto o direito humano à alimentação é muito mais forte do que o conceito de segurança alimentar. O direito à alimentação inclui todos os elementos da segurança alimentar - o que inclui disponibilidade, acessibilidade e uso do alimento -, mas vai além em razão de destacar o conceito de prestação de contas. Uma abordagem baseada em direitos evidencia o fato, segundo o qual a realização progressiva da redução da fome é uma obrigação legal, e não apenas escolha ou preferência. Ao final, depois de intensas negociações diplomáticas, o direito à alimentação foi reafirmado na Declaração Final, e os Governos concordaram em elaborar um conjunto de diretrizes voluntárias sobre o direito à alimentação.

A Declaração Final reafirma no seu terceiro parágrafo preambular "o direito de todos a terem acesso a alimentos seguros e nutritivos" e no parágrafo 10 "Convida o Conselho da FAO a estabelecer um Grupo de Trabalho Intergovernamental, para elaborar nos próximos dois anos um conjunto de diretrizes voluntárias para apoiar os esforços dos Estados-membros a alcançarem a realização progressiva do direito à alimentação adequada no contexto da segurança alimentar nacional". Esses importantes desenvolvimentos da $\mathrm{CMA}+5$ representaram pequenas sementes de esperança na luta contra a fome.

${ }^{197}$ FAO, Comitê sobre a Segurança Alimentar Mundial, $27^{\mathrm{a}}$ sessão. Fomentando a Vontade Política de Combater a Fome, Roma, 2001.

${ }^{198}$ ZIEGLER, Jean. The fight for the Right to Food: Lessons Learned, Palgrave Macmillan, 2011. ISBN:9780-230-28464-7.p7 e sgts. 
Esses êxitos diplomáticos e doutrinários foram conseguidos graças aos esforços de um variado número de países e de grupos, em especial, o Grupo dos 77, a Noruega, a Suiça, a Alemanha, a França, Cuba e Venezuela pela luta pela inclusão do direito à alimentação e das diretrizes voluntárias para a implementação do direito à alimentação na Declaração Final. 


\section{2 - DIRETRIZES VOLUNTÁRIAS EM APOIO À REALIZAÇÃo PROGRESSIVA DO DIREITO À ALIMENTAÇÃO ADEQUADA NO CONTEXTO DA SEGURANÇA ALIMENTAR NACIONAL (2004)}

Na Declaração da Cúpula Mundial sobre a Alimentação: Cinco Anos Depois (CMA+5), de junho de 2002, a sociedade internacional reafirmou a importância de reforçar o respeito a todos os direitos humanos e liberdades fundamentais, bem como convidou o Conselho da FAO a estabelecer um "Grupo de Trabalho Intergovernamental [...] com vistas a elaborar [...] um conjunto de diretrizes voluntárias, para apoiar os esforços dos Estados-membros encaminhados para alcançar a realização progressiva do direito à uma alimentação adequada no contexto da segurança alimentar nacional".

O Grupo de Trabalho foi criado em novembro de 2002, e reforçaram-se as relações de trabalho de diversos titulares de responsabilidades, em particular entre o Alto Comissariado das Nações Unidas para os Direitos Humanos e o Relator Especial para o direito à alimentação. Depois de dois anos de intensas e construtivas negociações e debates entre os membros do Grupo de Trabalho Intergovernamental e sua Mesa, assim como representantes das partes interessadas e a sociedade civil, o Conselho da FAO aprovou as Diretrizes Voluntárias em novembro de 2004.

Nas palavras do Diretor-Geral da FAO, à época, Jacques Diouf:

As Diretrizes Voluntárias representam a primeira tentativa de os governos interpretarem um direito econômico, social e cultural, e de se recomendar medidas que necessitam serem adotadas para a realização do direito à alimentação. $\mathrm{O}$ objetivo das Diretrizes Voluntárias é o de proporcionar orientação prática aos Estados com respeito aos seus esforços para conseguir a realização progressiva do direito à alimentação no contexto da segurança alimentar nacional, para alcançar as metas do Plano de Ação da Cúpula Mundial sobre a Alimentação (1996).

As partes interessadas poderiam beneficiar-se também dessas orientações. As Diretrizes Voluntárias abarcam 
todas as medidas distintas as quais os Governos devem considerar no âmbito doméstico, com o fim de estabelecer um entorno propício para que suas populações possam alimentar-se por si mesmas com dignidade, bem como criar redes de segurança apropriadas para aqueles que não têm condições de se alimentarem.

As Diretrizes podem ser empregadas para reforçar e melhorar os marcos de desenvolvimento existentes, especialmente em relação às dimensões sociais e humanas, colocando os direitos das pessoas de forma mais resoluta no centro do desenvolvimento. (gn)

As Diretrizes Voluntárias representam um passo em direção à integração dos direitos humanos no labor dos organismos que se ocupam da alimentação e da agricultura, como a FAO, tal como foi solicitado pelo Secretário Geral das Nações Unidas no contexto de seu programa de reforma da ONU.

As Diretrizes constituem um mecanismo adicional para lutar contra a fome e a pobreza, assim como acelerar a consecução dos objetivos de desenvolvimento do Milênio.

A FAO está comprometida em reforçar sua capacidade, com a ajuda dos Estados-membros, para ajudar os Governos desejosos da aplicação das Diretrizes Voluntárias. Com isso, a organização espera ter a oportunidade de cooperar com os governos e outros agentes fundamentais que desejem aplicar à redução da pobreza enfoques baseados nos direitos e que estejam interessados em realizar o direito à uma alimentação adequada no contexto da segurança alimentar nacional por meio da aplicação das Diretrizes Voluntárias.

Esforçar-se para conseguir que toda criança, mulher e homem disponha de uma alimentação adequada de forma habitual não é apenas um imperativo moral e um investimento que produz enormes benefícios econômicos, mas também equivale a 
realização de um direito humano básico ${ }^{199}$.

As Diretrizes Voluntárias consideram uma ampla gama de importantes considerações e princípios, como a igualdade e a ausência de discriminação, a participação e a inclusão, a obrigação de prestar contas e o Estado de direito, e o princípio de que todos os direitos humanos são universais, indivisíveis e interdependentes e, por isso, estão relacionados entre si. Os alimentos não deveriam ser usados como instrumentos de pressão política e econômica ${ }^{200}$.

Ao elaborar as Diretrizes, o Grupo de Trabalho Intergovernamental contou com a participação ativa de organizações internacionais, organizações não governamentais (ONGs) e representantes da sociedade civil. A aplicação dessas diretrizes, que é fundamentalmente responsabilidade dos Estados, será favorecida pela contribuição de todos os membros da sociedade civil em seu conjunto, incluídos os setores privados e as ONGs.

Essas diretrizes voluntárias constituem um instrumento prático baseado em direitos humanos dirigidos a todos os Estados. Não estabelecem obrigações juridicamente vinculantes nem para os Estados nem para as Organizações Internacionais, nem podem ser interpretadas de modo que suas disposições emendam, modificam ou alteram os direitos e obrigações dimanadas do direito internacional e nacional. Incentiva-se os Estados a aplicarem essas diretrizes voluntárias, quando elaborarem suas estratégias, políticas, programas e atividades, sem fazer quaisquer discriminações em razão da raça, cor, sexo, idioma, religião, opinião política, origem social ou nacional, posição econômica, nascimento ou qualquer outra condição social.

Apesar de as Diretrizes Voluntárias não serem um código de conduta que muitos Estados e organizações não governamentais estavam advogando, elas ainda assim são um importante marco de progresso. O processo de elaboração das diretrizes ajudou a fortalecer o entendimento dos Governos com relação ao direito à alimentação. A elaboração das diretrizes proporcionou um importante espaço para a reafirmação dos direitos humanos na luta pela erradicação da fome e desnutrição, bem como o desenvolvimento de uma melhor compreensão das obrigações internacionais com respeito

\footnotetext{
${ }^{199}$ FAO, Diretrizes Voluntárias em Apoio à Realização Progressiva do Direito à uma Alimentação Adequada no Contexto de Segurança Alimentar Nacional.Roma, 2005.ISBN 978-92-5-305336-0. p. iii e iv.

${ }^{200}$ ibidem.p. 3 e sgts.
} 
ao direito à alimentação ${ }^{201}$. O processo também proporcionou um importante fórum para a discussão e o compartilhamento de experiências para combater a fome e para esclarecer o direito à alimentação, conforme prometido no objetivo 7.4 do Plano de Ação de 1996.

As Diretrizes Voluntárias foram e ainda são inovadoras, no sentido de que elas proporcionam uma definição internacionalmente aceita do direito à alimentação (gn). A definição adotada pelos Governos segue, de perto, a definição adotada pelo Comitê de Direitos Econômicos, Sociais e Culturais. Ela também segue a interpretação oferecida pelo Comitê, segundo a qual os Estados estão obrigados a respeitarem, protegerem e satisfazerem o direito à alimentação adequada. Essa interpretação tem importantes implicações para a aceitação de todos os direitos econômicos, sociais e culturais.

O parágrafo 17 das Diretrizes Voluntárias afirma que:

...os Estados-partes do PIDESC têm a obrigação de respeitar, promover e proteger, bem como realizar ações apropriadas para alcançar, progressivamente, a plena realização do direito à alimentação adequada. Os Estados-partes devem respeitar os acessos existentes à alimentação adequada, ao não tomar quaisquer medidas que resultem em impedimento ao acesso, e devem proteger o direito de todos à alimentação adequada, ao agirem de modo que as empresas e os indivíduos não privem outros indivíduos do acesso deles à alimentação adequada.

Os Estados-partes devem promover políticas que tenham a intenção de contribuir para a realização progressiva do direito das pessoas à alimentação adequada, ao engajarem-se, proativamente, em atividades que busquem fortalecer o acesso e o uso dos recursos e dos meios que garantam a sobrevivência das pessoas, o que inclui a segurança alimentar.

${ }^{201}$ ZIEGLER, Jean. The fight for the Right to Food: Lessons Learned, Palgrave Macmillan, 2011. ISBN:9780-230-28464-7.p.8 e sgts. 
Os Estados-partes devem, na medida em que seus recursos permitam estabelecer e manter redes de segurança ou outra assistência, para protegerem aqueles que estão incapacitados de se alimentarem por si.

As Diretrizes Voluntárias também são vanguardistas no reconhecimento da dimensão internacional relacionada ao direito à alimentação, no tratamento de questões de comércio internacional, ajuda alimentar e embargos, por exemplo. Isso é importante, porque esse reconhecimento amplia o entendimento do direito à alimentação para além da tradicional relação entre Estado e súditos. Essa compreensão ampliada tem como alvo o maior reconhecimento das responsabilidades "extraterritoriais".

Esse conjunto de diretrizes também trata dos atores não governamentais, encorajando responsabilidade direta pelo direito à alimentação, bem como o aperfeiçoamento de regulamentações do mercado para garantir a segurança alimentar.

As Diretrizes Voluntárias também demonstram como o direito à alimentação pode ser incorporado nas estratégias de governos e de instituições. Elas mostram como os principais princípios de direitos humanos - não discriminação, participação, transparência, prestação de contas e acesso à justiça - podem ser incorporados na segurança alimentar por meio de uma abordagem baseada em direitos.

Elas instam os Estados a promoverem desenvolvimento econômico baseado numa concepção ampla que seja favorável às políticas de segurança alimentar (diretriz 2.1), que busquem o uso econômico, agrícola, pesqueiro e florestal da terra de modo inclusivo e não discriminatório, bem como a promoção de políticas de reformas fundiárias apropriadas (diretriz 2.5) e a incorporação do direito à alimentação em estratégias de redução de pobreza.

As Diretrizes Voluntárias encorajam os Estados a reconhecerem as deficiências dos mecanismos de mercado, de modo que protejam o meio ambiente e os bens públicos (diretriz 4.10), e que, particularmente, para as mulheres (diretriz 8.3) e grupos vulneráveis (diretriz 8.1): 
...os Estados devem respeitar e proteger os direitos individuais relativos aos recursos, como a terra, a água, as florestas, a pesca e os rebanhos sem qualquer discriminação. Quando for necessário e apropriado, os Estados devem empreender uma reforma agrária, assim como outras reformas de políticas em consonância com suas obrigações em matéria de direitos humanos e em conformidade com o Estado de direito, a fim de assegurar um acesso eficaz e equitativo às terras, bem como reforçar o crescimento em favor dos pobres. Atenção especial deve ser dada a grupos, como os pastores nômades e os povos indígenas, e a relação deles com os recursos naturais.

As Diretrizes Voluntárias também exortam os Estados a estabelecer mecanismos para informar o público de seus direitos e para melhorar o acesso à justiça em relação ao direito à alimentação (diretriz 7). Um maior reconhecimento do direito à alimentação adequada em jurisdição nacional e a garantia de acesso à justiça para todos e todas, com a prioridade para os mais pobres e mais vulneráveis, melhorarão de forma significativa a realização do direito à alimentação ${ }^{202}$.

Por fim, as Diretrizes Voluntárias têm o potencial para promover impactos muito positivos na luta pelo direito à alimentação. É essencial que elas sejam adotadas como um instrumento prático para orientar as políticas e os programas governamentais, de modo a terem um impacto real na erradicação da fome e da insegurança alimentar no mundo ${ }^{203}$.

${ }^{202}$ ZIEGLER, Jean. The fight for the Right to Food: Lessons Learned, Palgrave Macmillan, 2011. ISBN:9780-230-28464-7.p.9.

${ }^{203}$ ibidem.p. 9 


\section{3 - A CÚPULA DA SEGURANÇA ALIMENTAR (2009)}

A cúpula mundial sobre segurança alimentar, realizada em Roma, reuniu 60 chefes de Estado e uma grande quantidade de representantes de organizações intergovernamentais para tratar da desnutrição que afeta aproximadamente 1 bilhão de pessoas no mundo.

O encontro, ocorrido entre os dias 16 e 18 de novembro, foi realizado pela Organização das Nações Unidas para a Agricultura e a Alimentação (FAO, sigla em inglês), baseada em Roma. A Cúpula visou à revitalização do Comitê das Nações Unidas sobre Segurança Alimentar ${ }^{204}$ (CFS, sigla em inglês) e à superação dos desafios globais relacionados à fome no mundo, no entanto a declaração oficial resultante da reunião foi amplamente criticada por sua falta de substância.

204 O Comitê sobre Segurança Alimentar foi estabelecido em 1974 como um órgão intergovernamental para servir de fórum no Sistema das Nações Unidas para revisar e acompanhar políticas relativas à segurança alimentar, incluindo a produção e os acessos físico e econômico à alimentação. in Committee on Food Security Information Note. http://www.fao.org/fileadmin/templates/cfs/Docs0910/InfoNote/CFS_General_Info_Note_EN.pdf 


\subsection{1 - DISCURSO DE ABERTURA E ANÁliSE DA CRISE ALIMENTAR (2007-2008)}

Um dos pontos interessantes com respeito a essa Cúpula foi a participação do Papa Bento XVI para tomar a palavra na sessão inaugural do encontro mundial sobre a segurança alimentar ${ }^{205}$.

Dada a lucidez e a objetividade da análise papal acerca do contexto de crise financeira e alimentar à época do encontro, consideramos importante destacar algumas observações in verbis ${ }^{206}$.

A comunidade internacional está a enfrentar, ao longo destes últimos anos (2007-2009), uma grave crise econômica e financeira. As estatísticas demonstram o crescimento dramático do número de quantos sofrem de fome, e para ela concorrem o aumento dos preços dos produtos alimentares, a diminuição dos recursos econômicos das populações mais pobres, bem como o acesso limitado ao mercado e à alimentação. E tudo isto tem lugar, ao mesmo tempo em que se confirma o dado de que a terra é capaz de alimentar suficientemente todos os seus habitantes. Com efeito, não obstante em determinadas regiões ainda subsistam baixos níveis de produção agrícola, também por causa das mudanças climáticas, globalmente esta produção é suficiente para satisfazer tanto as exigências atuais como as que são previsíveis para o futuro. Estes dados indicam a ausência de uma relação de causa e

${ }^{205}$ A Santa Sé é entidade que comanda a Igreja Católica Apostólica Romana.

Ela é um sujeito de direito internacional, cujo status foi adquirido ao longo de séculos de influência na vida mundial, que remontam à época em que o poder temporal do Papado era amplo e abrangia a capacidade de estabelecer regras de conduta social válidas para o mundo inteiro, de resolver conflitos internacionais e de governar os Estados Pontifícios. Na atualidade, o Santo Padre ainda goza de status e prerrogativas de Chefe de Estado e continua a ter certa ascendência na sociedade internacional, como provam suas reiteradas manifestações em assuntos de interesse internacional. in PORTELA, Paulo Henrique Gonçalves. Direito Internacional Público e Privados, incluindo noções de direitos humanos e de direito comunitário. 3 ed. , editora juspodium. p.156.

206 http://www.vatican.va/holy_father/benedict_xvi/speeches/2009/november/documents/hf_benxvi_spe_20091116_fao_po.html 
efeito entre o crescimento da população e a fome, e isto é confirmado ulteriormente pela destruição deplorável de produtos alimentares em vista de manter certos lucros.

Na Carta Encíclica Caritas in veritate, observei que "a fome não depende tanto de uma escassez material, mas sobretudo da escassez de recursos sociais, o mais importante dos quais é de natureza institucional; isto é, falta um sistema de instituições econômicas que seja capaz de garantir um acesso regular e adequado..., à alimentação e à água e também de enfrentar as carências relacionadas com as necessidades primárias e com a emergência de reais e verdadeiras crises alimentares (...)".

Sucessivamente, acrescentei: "O problema da insegurança alimentar há de ser enfrentado numa perspectiva de longo prazo, eliminando as causas estruturais que a provocam e promovendo o desenvolvimento agrícola dos países mais pobres por meio de investimentos em infraestruturas rurais, sistemas de irrigação, transportes, organização dos mercados, formação e difusão de técnicas agrícolas apropriadas, isto é, capazes de utilizar o melhor possível os recursos humanos, naturais e socioeconômicos mais acessíveis em nível local, para garantir a sua manutenção de longo prazo" (‥ 27).

Neste contexto, é necessário impedir o recurso a determinadas formas de subvenções que prejudicam gravemente o setor agrícola, assim como a persistência de modelos alimentares orientados unicamente para o consumo, e desprovidos de uma perspectiva de maior envergadura e, acima de tudo, o egoísmo, que permite que a especulação penetre até no mercado dos cereais, colocando a alimentação ao mesmo nível das outras mercadorias.

A própria convocação deste encontro demonstra, num certo sentido, a debilidade dos mecanismos contemporâneos da segurança alimentar e a necessidade de voltar a considerá-los.

\section{3}


Efetivamente, não obstante os países mais pobres estejam mais amplamente integrados na economia mundial do que no passado, o funcionamento dos mercados internacionais torna-os mais vulneráveis, obrigando-os a recorrer à ajuda das instituições intergovernamentais, que oferecem uma assistência preciosa e indispensável. No entanto, o conceito de cooperação deve estar em coerência com o princípio de subsidiariedade. É necessário envolver "as comunidades locais nas opções e nas decisões relativas ao uso da terra cultivável" (ibidem), uma vez que o desenvolvimento humano integral exige opções responsáveis da parte de todos e requer uma atitude solidária que não considere a assistência ou a emergência como uma oportunidade lucrativa para aqueles que põem à disposição os recursos ou para certos grupos privilegiados que se encontram entre os beneficiários.

Aos países que têm necessidade de assistência externa, a comunidade internacional tem o dever de responder mediante os instrumentos da cooperação, sentindo-se corresponsável pelo seu desenvolvimento, "através da solidariedade feita de presença, de acompanhamento, de formação e de respeito" (ibid., n. 47). No interior deste contexto de responsabilidade, insere-se o direito que cada país tem de definir o próprio modelo econômico, prevendo os modos para garantir a sua liberdade de escolha e de finalidades. Em tal perspectiva, a cooperação deve tornar-se um instrumento eficaz, livre de vínculos e de interesses que podem absorver uma parte não indiferente dos recursos destinados ao desenvolvimento. Além disso, é importante ressaltar o modo como a vereda da solidariedade para com o desenvolvimento dos países mais pobres pode constituir inclusive um caminho de solução da crise global contemporânea. Com efeito, ajudando estas nações mediante planos de financiamento inspirados pela solidariedade, a fim de que elas mesmas consigam prover à satisfação das exigências de consumo e de desenvolvimento que lhes são próprias, não só se favorece a prosperidade econômica no 
seu interior, mas também se podem ter repercussões positivas sobre o desenvolvimento humano integral em outros países (cf. $\underline{i b i d}$., $\mathrm{n}$. 27).

Atualmente, ainda subsiste um nível desigual de desenvolvimento no seio das nações e entre as nações, o que determina, em numerosas regiões da terra, condições de precariedade, que depois acentuam o contraste entre a pobreza e a riqueza. Esta constatação não diz respeito só aos modelos de desenvolvimento, mas também e sobretudo à própria percepção que se tem de um fenômeno como a insegurança alimentar: existe o risco concreto de que a fome venha a ser considerada como estrutural, como uma parte integrante da realidade sociopolítica dos países mais vulneráveis, e seja, por conseguinte, objeto de um sentido de desânimo resignado, ou até de indiferença. Não é assim, e não deve ser assim!

Para combater e debelar a fome, é essencial começar a redefinir os conceitos e os princípios até aqui aplicados nas relações internacionais, de maneira a responder à seguinte interrogação: o que pode orientar a atenção e a ação dos Estados que dela deriva rumo às necessidades dos mais desfavorecidos?

Não se deve procurar uma resposta no perfil operacional da cooperação, mas sim nos princípios que a devem inspirar. É unicamente em nome da pertença comum à família humana universal que se pode exigir de cada povo, e, portanto, de cada país, que seja solidário, isto é, que esteja disposto a assumir responsabilidades concretas para ir ao encontro das necessidades do próximo, para favorecer uma verdadeira partilha fundamentada sobre amor. 


\subsection{2 - OBJETIVOS ESTRATÉGICOS DECLARADOS PELA CÚPULA}

Ao aprovar a Declaração, os Chefes de Estado e de Governo, bem como os representantes da Comunidade Europeia decidiram pelos quatro objetivos estratégicos seguintes:

7.1 - Assegurar uma ação urgente nos planos nacional, regional e mundial com vista à plena realização do primeiro Objetivo de Desenvolvimento do Milênio e do objetivo da Cúpula Mundial sobre a Alimentação de 1996, que consistem em reduzir à metade a proporção e o número, respectivamente, de pessoas que sofrem com a fome e a má-nutrição até o ano de 2015.

7.2 - Juntar nossos esforços e competências para trabalhar na Aliança Mundial para a Agricultura, a Segurança Alimentar e a Nutrição - aproveitando as estruturas existentes para melhorar a governança e a cooperação -, para promover uma melhor coordenação nos planos mundial, regional e nacional e garantir que se expressem e que levem em consideração os interesses nacionais e regionais. Por conseguinte, os Chefes de Estado e de Governo comprometem-se a executar plenamente a reforma do CFS, o qual, como principal plataforma internacional e intergovernamental inclusiva para uma ampla gama de partes interessadas comprometidas em trabalharem juntas, é um componente central dos nossos esforços para promover a Aliança Mundial para a Agricultura, a Segurança Alimentar e a Nutrição.

7.3 - Inverter a tendência de diminuição do financiamento nacional e internacional para a agricultura, a segurança alimentar e o desenvolvimento rural nos países em desenvolvimento e promover novos investimentos com o objetivo de incrementar a produção agrícola sustentável e a produtividade da agricultura, reduzir a pobreza e obrar pelo êxito da segurança alimentar e o acesso aos alimentos para todos.

7.4 - Enfrentar de forma proativa os desafios que impõem a mudança climática para a segurança alimentar mundial e as necessidades de adaptação da agricultura, assim como aumentar a capacidade de resposta dos produtores agrícolas em relação às mudanças climáticas, com especial atenção para os pequenos agricultores e as populações vulneráveis. 


\subsection{3 - PRINCÍPIOS DE ROMA E O COMITÊ SOBRE A SEGURANÇA ALIMENTAR (CFS)}

Com vista a alcançar esses objetivos estratégicos, a comunidade internacional baseou seus compromissos e ações nos cinco Princípios de Roma para a segurança alimentar sustentável, que estão elencados a seguir:

1 - Investir em planos nacionais que tenham por finalidade canalizar recursos para associações e programas bem desenhados e baseados em resultados.

2 - Fomentar a coordenação estratégica nos planos nacional, regional e mundial para melhorar a governança, promover uma melhor destinação de recursos, para evitar a duplicação de esforços e corrigir insuficiências nas respostas.

A Aliança Mundial para a Agricultura, a Segurança Alimentar e a Nutrição lutará para conseguir a coordenação estratégica dos esforços nos planos nacional, regional e mundial, baseando-se em estruturas já existentes, garantindo-se o caráter inclusivo da participação e promovendo um autêntico enfoque de baixo para cima baseado nas experiências e na evolução sobre o terreno.

Por conseguinte, a comunidade internacional acolhe, com beneplácito, os esforços do CFS para assegurar que se escutem todas as vozes de todas as partes interessadas - especialmente as mais afetadas pela insegurança alimentar. Aprovamos a função do CFS como plataforma para o debate e a coordenação, com o fim de fortalecer uma atuação em colaboração entre os governos, organizações regionais, organismos internacionais, organizações não governamentais (ONGs), organizações da sociedade civil, organizações de produtores de alimentos, organizações do setor privado, de uma maneira que respeite o contexto específico e as necessidades concretas de cada país.

A comunidade internacional apoia plenamente as importantes funções do CFS, em particular nas áreas da coordenação em nível mundial, a convergência das políticas, assim como a facilitação do apoio e assessoramento aos países e regiões. No contexto do plano de execução estabelecido na reforma do CFS, este Comitê assumirá, gradualmente, funções adicionais tais como a de fomentar a coordenação nos planos nacional e regional, promover a prestação de contas e divulgar as melhores práticas em 
todos os níveis e elaborar um marco estratégico para a segurança alimentar e a nutrição ${ }^{207}$.

3 - Fomentar um planejamento dual e amplo da segurança alimentar que compreenda: a) medidas diretas destinadas às pessoas mais vulneráveis para fazer imediatamente frente à fome e b) programas sustentáveis a médio e longo prazo sobre agricultura, segurança alimentar, nutrição e desenvolvimento rural a fim de eliminar as causas fundamentais da fome e da pobreza, entre outros meios por intermédio da realização progressiva do direito a uma alimentação adequada.

4 - Assegurar um papel importante do sistema multilateral através da constante melhora da eficiência, capacidade de resposta, coordenação e eficácia das instituições multilaterais.

5 - Garantir o compromisso substancial e duradouro de todos os associados em investir na agricultura assim como na segurança alimentar e nutrição, proporcionando de maneira oportuna e previsível os recursos necessários para planos e programas plurianuais.

No encerramento do evento, o diretor-geral da FAO, Jacques Diouf, expressou descontentamento com a falta de acordo em torno de "metas e prazos que permitissem melhor monitoramento e implementação". Olivier De Schutter, relator especial das Nações Unidas para o Direito à Alimentação, notou que as antigas abordagens para resolver o problema da fome fracassaram em razão da "falta de responsabilidade e acompanhamento dos compromissos firmados Cúpula após Cúpula".

207 Durante o ano de 2009, o CFS submeteu-se a reformas para torná-lo mais efetivo por meio da inclusão de um grupo mais abrangente de partes interessadas e do aumento de sua competência para promover políticas para reduzir a segurança alimentar.

A perspectiva de um Comitê reformado é a de ser a mais inclusiva plataforma internacional e intergovernamental para todos os interessados trabalharem juntos para garantir a segurança alimentar e nutricional para todos e todas. O CFS reformado trabalhará de forma coordenada em apoio aos processos empreendidos pelos países cuja meta é segurança alimentar.in Committee on Food Security Information Note 


\section{8 - O COMITÊ DE DIREITOS ECONÔMICOS, SOCIAIS E CULTURAIS E SEU MODELO PRESCRITIVO: O PROTOCOLO FACULTATIVO DO PIDESC ${ }^{208}$}

Em 1990, materializou-se a ideia do Comitê DESC iniciar o estudo sobre um Protocolo Facultativo que estabeleceria a possibilidade de comunicações individuais em casos de violações dos direitos contidos no PIDESC. Em 1993, os Estados participantes da Conferência de Viena reafirmaram a indivisibilidade e a interdependência de todos os direitos humanos e recomendaram à Comissão de Direitos Humanos que cooperasse com o Comitê DESC para o estudo de um protocolo facultativo.

O Comitê DESC apresentou um esboço de protocolo facultativo (E/CN.4/1997/105) à Comissão de Direitos Humanos em 1996. Nele, todos os direitos substancialmente reconhecidos no PIDESC poderiam ser objeto de recursos. Essa colocação muito ampla do Comitê pretende ser um critério global no sentido de que todo Estado que se adere ao protocolo facultativo deverá aceitar que o procedimento estabelecido para a apresentação das comunicações e denúncias seja aplicado para todos os direitos enunciados nos artigos 2 a 15 do PIDESC ${ }^{209}$.

Ainda que vários Estados fossem a favor desse projeto de protocolo, apenas houve avanços nesse processo em 2001, quando a Comissão nomeou um especialista independente, Hatem Kotrane, encarregado de examinar a questão de um projeto de protocolo facultativo do PIDESC.

Em seu $57^{\circ}$ período de sessões, a Comissão de Direitos Humanos decidiu, em sua resolução 2001/30, nomear um especialista independente encarregado de examinar a questão de um projeto de protocolo facultativo do Pacto Internacional de Direitos Econômicos, Sociais e Culturais, tendo em conta (i) o informe do Comitê de Direitos Humanos, Econômicos, Sociais e Culturais à Comissão acerca de um projeto de protocolo facultativo (E/CN.4/1997/105), (ii) as observações formuladas a respeito pelos Estados, organizações intergovernamentais e organizações não governamentais, assim

${ }^{209}$ E/CN.4/2003/53 - Os Direitos Econômicos, Sociais e Culturais - Situação dos Pactos Internacionais de Direitos Humanos - Informe do sr. Hatem Kotrane, especialista independente encarregado de examinar a questão do projeto de protocolo facultativo do PIDESC. p.23 e sgts. 
como (iii) o informe do seminário sobre justiciabilidade dos direitos econômicos, sociais e culturais. A Comissão pediu para o especialista apresentar um relatório à Comissão em sua $58^{\mathrm{a}}$ sessão, a fim de ela estudar as possíveis medidas complementares e as ações futuras, e, em particular, a possível criação de um grupo de trabalho, de composição aberta, para debater o projeto de protocolo facultativo do Pacto.

Em sua $58^{\text {a }}$ sessão, a Comissão aprovou a resolução 2002/24, em que "tomou nota com interesse o informe do especialista independente encarregado de examinar a questão do projeto de protocolo facultativo do PIDESC e as recomendações formuladas por ele". Nesse sentido, a Comissão decidiu "estabelecer, em sua 59a sessão, um grupo de trabalho com vistas a estudar as opções relativas à elaboração de um protocolo facultativo do PIDESC", bem como decidiu prorrogar o mandato do especialista independente para que estudasse as seguintes questões:

i) A questão do caráter e do alcance das obrigações dos Estados-partes de acordo com o Pacto;

ii) A questões conceituais sobre a justiciabilidade dos direitos econômicos, sociais e culturais, com particular referência à experiência adquirida nos últimos anos na aplicação dos instrumentos e dos mecanismos de direitos humanos universais, regionais e nacionais;

iii) a questão da conveniência e da viabilidade de um mecanismo encarregado de examinar as denúncias com respeito ao Pacto e a questão da complementaridade entre os distintos mecanismos.(gn)

O especialista independente realizou amplas consultas.

Em 2 de junho de 2002, foi enviada uma nota verbal aos Estados, assim como cartas a organizações e especialistas interessados, nas quais lhes era pedido contribuições em relação às três questões acima. Em 15 de novembro de 2002, o especialista independente já tinha recebido respostas da Argentina, de Cuba, da Itália, do México, dos Países Baixos, de Portugal, da República Islâmica do Irã, da República Tcheca, da Suécia, da Tailândia, da Organização Mundial de Saúde e de um grupo de 56 organizações não governamentais. O Alto Comissariado preparou também uma nota de conjunto que abarcava as três questões mencionadas. De sua parte, a Comissão Internacional de Juristas organizou uma mesa redonda sobre as mesmas questões e apresentou um informe ao especialista independente $\mathrm{e}^{210}$

${ }^{210}$ Comitê DESC, Observação Geral \#12. E/C.12/1999/5E/CN.4/2003/53 - Os Direitos Econômicos, Sociais 


\section{1. - A CONVENIÊNCIA E A VIABILIDADE DO PROTOCOLO COMO MECANISMO DE DENÚNCIA}

No que concerne a conveniência e a viabilidade de um mecanismo encarregado de examinar as denúncias apresentadas em razão do Pacto, o especialista independente "confia haver contribuído para que se tome uma maior consciência da conveniência de reconhecer a justiciabilidade do conjunto de direitos econômicos, sociais e culturais" $^{211}$.

Nas palavras do especialista independente, "a experiência adquirida nos últimos anos na aplicação dos instrumentos e mecanismos internacionais, regionais e nacionais de direitos humanos, permite, sem dúvida, reduzir sensivelmente o conteúdo dos argumentos derivados da soberania dos Estados. Nesse sentido, destacam-se argumentos soberanistas, como o risco de um procedimento de denúncia em razão do Pacto poder servir, às vezes, de pretexto para que o órgão internacional encarregado da questão se veja obrigado a examinar, detalhadamente, a política econômica, social e cultural de um país, com a conseguinte ingerência inaceitável em âmbito que o Estado teria, normalmente, uma competência exclusiva em direito internacional".

A juízo do especialista independente, esses argumentos não podem constituir um obstáculo decisivo na justiciabilidade dos direitos econômicos, sociais e culturais. [...] Um protocolo facultativo do Pacto permitiria dar maior efetividade ao Pacto, pois os Estados-partes do Pacto comprometeram -se a garantir o pleno exercício dos direitos nele reconhecidos e a cooperarem com vista a realizar os objetivos acordados no PIDESC. Um protocolo facultativo permitiria confirmar mais uma vez os princípios reconhecidos na Declaração e Programa de Ação de Viena, segundo os quais os direitos humanos são "universais, indivisíveis e interdependentes e estão relacionados entre si", sendo assim que não podem ser objeto de tentativa alguma de hierarquização.

Além dessas, podem-se obter outras vantagens com base no estabelecimento de um mecanismo encarregado de examinar as denúncias apresentadas em

e Culturais - Situação dos Pactos Internacionais de Direitos Humanos - Informe do sr. Hatem Kotrane, especialista independente encarregado de examinar a questão do projeto de protocolo facultativo do PIDESC. p.5 e sgts.

${ }^{211}$ ibidem.p. 20 e sgts. 
virtude do Pacto, em particular ${ }^{212}$ :

\section{a) Aplicação do direito de toda pessoa a interpor um recurso.}

Uma das principais orientações do direito internacional em matéria de direitos humanos é, sem dúvida, o direito de toda pessoa a interpor um recurso em caso de violação de seus direitos fundamentais. Um mecanismo encarregado de examinar as denúncias apresentadas por particulares constituirá uma medida importante para o exercício desse direito no plano internacional.

\section{b) Desenvolvimento do direito internacional.}

A elaboração de um procedimento de exame de denúncias apresentadas em razão do Pacto contribuirá, sem dúvida, graças ao exame de casos concretos e de situações reais, para a elaboração de um corpo coerente de princípios que abarque o conjunto de direitos enunciados no Pacto e que são suscetíveis de adquirir, progressivamente, uma autoridade reconhecida por todos, tanto meios internacionais quanto pelos países onde os direitos econômicos e sociais poderão ser usados para elaborar as legislações nacionais.

Os princípios assim estabelecidos serviriam de complemento ao trabalho metódico que se tem realizado nos últimos anos para explicar a natureza e o alcance dos direitos econômicos, sociais e culturais, graças às Observações Gerais do Comitê DESC encarregado de examinar os informes apresentados pelos Estados e as resoluções da Comissão de Direitos Humanos. Nesse processo, falta um elo, a saber: um mecanismo de exame das denúncias apresentadas por particulares que seja capaz de desenvolver a jurisprudência no plano internacional fundando-se em fatos concretos.

\section{c) Unidade dos Direitos Econômicos, Sociais e Culturais em seu}

conjunto.

O protocolo facultativo será o único mecanismo que permite às pessoas obterem reparações por violações de quaisquer direitos reconhecidos no PIDESC. Muito embora seja certo que existam outros mecanismos encarregados de examinarem as denúncias com respeito às questões econômicas, sociais e culturais no plano internacional,

${ }^{212}$ ibidem.p.21. 
o PIDESC é o único instrumento global consagrado a esse conjunto de direitos.

Um mecanismo de exame das denúncias apresentadas em virtude do Pacto contribuirá para respaldar mais ativamente o princípio da indivisibilidade e da interdependência no âmbito mesmo da categoria dos direitos econômicos sociais e culturais. Então, um grande número de temas poderão versar sobre vários direitos, sendo assim que uma violação do direito à alimentação estará vinculada, por exemplo, ao direito à moradia ou à saúde.

\section{$8.2 \quad$ - A VIGÊNCIA DO PROTOCOLO E A JUSTICIABILIDADE DOS DIREITOS ECONÔMICOS, SOCIAIS E CULTURAIS}

O protocolo facultativo foi adotado pela Assembleia Geral das Nações Unidas em 10 de Dezembro de 2008, data simbólica do sexagésimo aniversário da DUDH1948, e confere ao Comitê de Direitos Econômicos, Sociais e Culturais a competência de receber e de considerar queixas de presumidas vítimas de violações dos direitos incluídos no PIDESC, bem como conduzir investigações em casos de graves ou sistemáticas violações. A capacidade das vítimas reclamarem de violações dos direitos delas a mecanismos internacionais dá sentido aos direitos consagrados na Carta Internacional de Direitos Humanos e outros tratados de direitos humanos. Na sequência da décima ratificação, o protocolo facultativo passou a viger em 5 de Maio de 2013. O protocolo conta com 45 assinaturas e com 12 Estados-partes.

Na perspectiva de um membro do Comitê DESC, Eibe Riedel:

O protocolo facultativo influenciará o desenvolvimento dos direitos econômicos, sociais e culturais tanto quanto o protocolo facultativo do Pacto Internacional de Direitos Civis e Políticos tem influenciado. Como sabemos, o conteúdo exato das normas é refinado por meio da prática do Comitê, ou seja, suas Observações Gerais, suas declarações, seus diálogos com os Estados-partes, e também suas comunicações individuais, para quando o tempo for propício sentidos mais claros das normas sejam elaborados. 
O objetivo do protocolo facultativo é o de seduzir o Estado a pôr em vigor as recomendações baseadas nas obrigações internacionais de direitos humanos. Outro efeito do protocolo DESC será o de vermos exemplos concretos e individuais de como certo direito pode ser implementado, quando comparado com o procedimento regular dos relatórios periódicos, que cobrem temas com base numa perspectiva mais ampla e, portanto, capturam com menos atenção o nível doméstico. Esses casos individuais podem ter um escopo limitado, mas, em alguns casos, podem servir como um marco para a interpretação de casos similares $^{213}$.

$\mathrm{Na}$ celebração do primeiro aniversário da vigência do protocolo facultativo do PIDESC, em conferência do dia 9 de Abril de 2014, a Alta Comissária, Navi Pillay, destacou que "o protocolo facultativo capacita indivíduos cujos direitos econômicos, sociais e culturais tenham sido violados - e que não tenham conseguido encontrar reparações em nível nacional - a submeterem os casos deles ao Comitê de Direitos Econômicos, Sociais e Culturais. Logo, o protocolo contribui para garantir, significativamente, o acesso à justiça, assim como induz os Estados a adotarem remédios adequados nacionalmente" 214 .

Após longa luta pela exigibilidade e justiciabilidade dos direitos econômicos, sociais e culturais, com o protocolo facultativo, abre-se o acesso à justiça internacional. Com a participação das vítimas, avança-se na defesa desses direitos, os quais também são chamados direitos à justiça e à igualdade, que têm como finalidade principal garantir o bem-estar econômico, uma justiça social real e progressiva, e o acesso de todos à cultura do conjunto social, buscando a distribuição dos benefícios do progresso e do desenvolvimento e nivelando desigualdades ${ }^{215}$.

O novo procedimento contribuirá para que se prossiga no esclarecimento

213 ALTO COMISSARIADO das NAÇÔES UNIDAS para os DIREITOS HUMANOS. PERIÓDICO Da Divisão de Tratados de Direitos Humanos \#18 Out-Dez.2012. Entrevista com Eide Ridel (CDESC) sobre procedimentos de comunicações individuais.p.3

214 Discurso da Alta Comissária para a celebração de primeiro aniversário da vigência do Protocolo Facultativo do Pacto Internacional de Direitos Econômicos, Sociais e Culturais. 9 abril de 2014. in http://www.ohchr.org/EN/NewsEvents/Pages/DisplayNews.aspx?NewsID=14493\&LangID=E

215 VILLAGRA, Soledad. Protocolo Facultativo ao PIDESC: uma ferramenta para exigir os DESC. Assunção.2008.INESC.Plataforma Dhesca Brasil ISBN-978 85-87386-20-5.p.12 
e identificação das obrigações dos Estados com relação aos DESCs, impulsionando o desenvolvimento de uma jurisprudência internacional e nacional para sua proteção. Ao mesmo tempo, este novo mecanismo do Comitê DESC coloca em prática o aclamado princípio da indivisibilidade e interdependência de todos os direitos humanos, já que os direitos econômicos, sociais e culturais por muito tempo permaneceram em desvantagem em relação aos direitos civis.

O protocolo estabelece quatro formas de apresentar denúncias perante o Comitê DESC sobre as violações aos direitos do PIDESC cometidas por um Estado-parte. A primeira e mais esperada é por intermédio de comunicações individuais: por pessoas ou grupos de pessoas. A segunda é por meio da adoção de medidas provisionais. A terceira é a queixa de um Estado-parte contra outro, via comunicação entre eles, sempre que houver uma ratificação expressa de ambos Estados ao artigo 10.1 ${ }^{216}$. A última forma é o procedimento de investigação (ativado com a ratificação expressa do Estado-parte ao artigo $11.1^{217}$ ) para violações graves ou sistemáticas dos direitos, quando o Comitê DESC recebe informação confiável deste tipo de violações.

\footnotetext{
${ }^{216}$ Artigo 10.1 Procedimento entre Estados. Qualquer Estado-Parte signatário do presente Protocolo pode a qualquer tempo declarar, conforme este artigo, que reconhece a competência do Comitê para receber e considerar comunicações em que um Estado- Parte alega que outro Estado-Parte não está cumprindo com suas obrigações previstas neste Pacto.

Comunicações de acordo com o presente artigo podem ser recebidas e consideradas somente se forem submetidas por um Estado-Parte que tenha feito uma declaração reconhecendo a competência do Comitê para tal. Nenhuma comunicação será recebida pelo Comitê se ela concerne um Estado-Parte que não fez tal declaração.

${ }^{217}$ Artigo 11.1.Procedimento de Investigação. Um Estado-Parte signatário do presente Protocolo pode a qualquer tempo declarar que reconhece a competência do Comitê estabelecida no presente artigo.
} 


\section{9 - CONCLUSÃO: FOME-DOME-MEDO do MUNDO da VIDA: O DIREITO À ALIMENTAÇÃO E A ESQUIZOFRENIA DO PODER}

"Assim ouvimos. Certa ocasião, o Abençoado estava em Uruvela às margens do rio Neranjara ao pé de uma figueira-dos-pagodes, pouco tempo depois de ter alcançado a perfeita iluminação - ele ficou sentado em meditação sob a sombra dessa árvore por sete dias sem parar, sensível à felicidade da libertação. Ao final de sete dias, após emergir daquela concentração, ele examinou o mundo com o olho de um Buda. Ao fazer isso, ele viu seres ardendo com muitas febres e em chamas com o fogo da cobiça, da raiva e da delusão. Então, dando-se conta do significado disso, o Abençoado nessa ocasião exclamou" 218 :

O mundo está em chamas.

Afligido pelo contato, nomeia a doença -"eu".

Pois qualquer que seja a concepção, o fato é sempre distinto desta ${ }^{219}$.

Tornando-se distinto, o mundo é suportado pelo existir e pelo ser, atormentado pelo existir e pelo ser, mas se delicia com esse mesmo existir e ser.

Onde há deleite, há medo. Aquilo que amedronta causa sofrimento.

[...] Este sofrimento surge na dependência das aquisições. Com o fim de todo o apego, nenhum sofrimento é produzido.

Olhem para o mundo, os seres atormentados pela

\footnotetext{
${ }^{218}$ BUDA, Gotama. Loka Sutta (o Mundo). Udana III.10.O Udana, o terceiro livro do Khuddaka Nikaya que consiste de oitenta suttas curtos, recebe esse nome do pronunciamento feito ao final de cada discurso, em geral sob a forma de versos, prefaciados pela frase "Então, dando-se conta do significado disso, o Abençoado nessa ocasião exclamou".

Os oitenta suttas estão organizados em oito vagas, ou capítulos. in http://www.acessoaoinsight.net/sutta/udana.php

${ }^{219}$ Os cinco agregados (forma, sensação, percepção, consciência, formações) são tratados como doença, visto que são, essencialmente, insatisfatórios e a base do sofrimento, mas em razão da ignorância, do entendimento incorreto e do desejo sensual, as pessoas comuns equivocam-se, ao considerá-los como permanentes, constantes, prazerosos e como um "eu" ou "meu".

Não importa como as pessoas concebam - por serem impermanentes, insatisfatórios e não-eu - a realidade será distinta da concepção deludida.
} 
ignorância não estão libertos do deleite por aquilo que existe.

Todos os tipos de ser e de existir, em qualquer lugar, de qualquer modo, são impermanentes, sujeitos ao sofrimento, cuja natureza é a mudança.

Vendo isso como na verdade é, com correta sabedoria, o desejo por ser e por existir é abandonado, sem, no entanto, deliciar-se com o não existir e o não ser.

Nibbana é o completo desapego e cessação, realizado com a completa destruição do desejo.

Baseado nas experiências do primeiro Relator Especial para o Direito à Alimentação, descriminaremos os principais obstáculos à efetivação desse direito básico $^{220}$. Segundo Jean Ziegler, no começo de seu mandato de relator, ele identificou sete problemas maiores que diretamente afetam ou impedem a realização do direito à alimentação.

1) Problemas ligados ao comércio internacional;

2) Serviço da dívida externa e seu impacto na segurança alimentar;

3) Desenvolvimento da biotecnologia e seu impacto no acesso à alimentação;

4) Guerras e o destrutivo impacto delas na segurança alimentar;

5) Corrupção;

6) Acesso à terra e ao crédito;

7) Discriminação contra as mulheres e seu impacto na segurança alimentar.

Nas palavras do próprio relator:

Hoje, estou convencido de que um dos maiores obstáculos à realização do direito à alimentação é a esquizofrenia no sistema das Nações Unidas e nas políticas estatais, as quais, de um lado, apoiam a promoção do direito à alimentação, mas, ao mesmo tempo, agem para o enfraquecer.(gn)

${ }^{220}$ ZIEGLER, Jean. The fight for the Right to Food: Lessons Learned, Palgrave Macmillan, 2011. ISBN:9780-230-28464-7 
O primeiro aspecto dessa "esquizofrenia" é a existência de contradições internas profundas na comunidade internacional. De um lado, as agências das Nações Unidas, como a FAO, o Programa Alimentar Mundial, o Programa das Nações Unidas para o Desenvolvimento e o Fundo das Nações Unidas para a Infância enfatizam a justiça social e os direitos humanos e fazem um trabalho excelente na promoção do direito à alimentação, como evidenciado, por exemplo, pelas Diretrizes Voluntárias da FAO para o Direito à Alimentação. De outro lado, as instituições de Bretton Woods, juntamente com o Governo dos Estados Unidos da América e a Organização Mundial do Comércio recusam- -se a reconhecer a mera existência de um direito humano à alimentação e impõem aos Estados mais vulneráveis o "Consenso de Washington", que enfatiza a liberalização, a desregulamentação, a privatização e a compressão dos orçamentos domésticos dos Estados. Um modelo que, em muitos casos, produz maiores desigualdades.

Alguns Governos e importantes organizações intergovernamentais apoiam a teoria neoliberal. Essa teoria não reconhece a existência dos direitos humanos econômicos, sociais e culturais, bem como sustenta que somente os direitos políticos e civis são direitos humanos. De acordo com essa teoria totalmente irracional, somente um mercado mundial totalmente liberalizado, privatizado e unificado pode, gradualmente, eliminar a fome e a desnutrição no mundo. A evidência mostra o contrário liberalização e privatização têm progredido rapidamente na maioria dos países durantes os últimos 10 anos (2000-2010), ao mesmo tempo em que, mais pessoas do que nunca sofrem de grave ou permanente subnutrição. 
O segundo aspecto dessa "esquizofrenia" é o de muitos Estados não serem de modo algum coerentes tanto quanto suas próprias práticas são consideradas. Muito frequentemente, uma parte de um Governo assume a proteção e a promoção do direito à alimentação, enquanto outra parte de um governo toma decisões ou implementa políticas que diretamente minam esse direito. Por exemplo, enquanto os Governos se comprometem a sustentar um desenvolvimento baseado em direitos, eles podem também adotar políticas comerciais, financeiras, monetárias que têm efeitos negativos nos direitos humanos de outros países. Os governos votam pelo direito à alimentação no Conselho de Direitos Humanos da ONU e votam contra ele na Organização Mundial do Comércio, uma vez que grandes disparidades no poder econômico dos Estados significam que os Estados poderosos negociam regras de comércio que não são nem livres nem justas. Essas regras afetam severamente pequenos produtores e ameaçam a segurança alimentar, especialmente em países em desenvolvimento que precisaram liberalizar seu setor agrícola em maior grau do que os países desenvolvidos.

Para nós, diante de todo o exposto, consideramos que as obrigações internacionais e nacionais dos Estados são tratadas, esquizofrenicamente, com linguagens essencialmente diversas, de sorte que há uma colisão entre os princípios pro homine com o da livre iniciativa em termos de reciprocidade entre obrigações estatais e direitos.humanos e direito negocial. Entendemos que a responsabilidade dos Estados perante as obrigações referentes aos Pactos Internacionais, em especial, àquelas referentes aos direitos econômicos, sociais e culturais, devam ser entendidas e tratadas de modo objetivo, uma vez que as consequências da omissão, da negligência, da imperícia e da imprudência dos Estados em relação ao bem-estar dos povos com suporte na Carta Internacional de Direitos Humanos, em última análise, levam à completa desestabilização da ordem pública, como, por exemplo, atos revolucionários, insurreições e revoltas da fome. 
Enquanto os direitos humanos fundamentam sua reciprocidade em práticas de cooperação e de solidariedade em favor do indivíduo, de grupos minoritários e do povo, a reciprocidade do mercado baseia-se na ênfase em termos bancário, o que significa que a abstenção dos governos na interferência dos trabalhos do livre mercado é a condição sine qua non da facilidade em se liberar empréstimos e promover investimentos produtivos ou de capitais nas políticas estatais e na iniciativa privada.

Dessa forma, a prática de linguagens diferentes com respeito às obrigações dos Estados nacionais tem sua expressão mais explícita nas agendas de desenvolvimento internacional e domésticas. Em especial, nesse domínio do desenvolvimento sobre qual modelo seguir, isto é, um modelo orientado para o mercado ou um modelo baseado em direitos, nunca foi tão atual o paradoxo do asno de Buridan. $\mathrm{O}$ paradoxo conhecido como o asno de Buridan não foi originado pelo próprio Jean Buridan. É encontrado na obra De Caelo, de Aristóteles, onde o autor pergunta como um cão diante de duas refeições igualmente tentadoras poderia racionalmente escolher entre elas.

Buridan em nenhum momento discute este problema específico mas sua relevância é que ele defende um determinismo moral pelo qual, salvo por ignorância ou impedimento, um ser humano diante de cursos alternativos de ação deve sempre escolher o maior bem. Buridan defendia que a escolha devia ser adiada até que se tivesse mais informação sobre o resultado de cada ação possível. Escritores posteriores satirizaram este ponto de vista imaginando um burro que, diante de dois montes de feno igualmente acessíveis e apetitosos, deveria deter-se enquanto pondera por uma decisão.

Por enquanto, os críticos de Buridan prevalecem, pois entre a razão de mercado e o direito à alimentação a antinomia é absoluta.

As obrigações internacionais constantes nos Pactos de 1966 são as mesmas, quais sejam de os Estados resguardarem e promoverem a dignidade humana por intermédio de condições culturais, políticas, econômicas, civis e sociais que permitam o desenvolvimento pleno e livre da personalidade humana, maior aspiração individual, e, com efeito, a autodeterminação dos povos em escala do Estado nacional. O respeito e a promoção da dignidade humana representam formas de cultivo da vida e de respeito à morte. 
"Isso foi dito pelo Abençoado, dito pelo Arahant, assim ouvimos"221:

Se os seres soubessem, como eu sei, os resultados de dar e de compartir, eles não comeriam sem antes terem dado, nem permitiriam que a mácula do egoísmo tome conta das suas mentes. Mesmo se fosse o seu último bocado, a sua última mordida, eles não comeriam sem terem compartido, se houvesse alguém com quem compartir. Mas porque os seres não sabem, como eu sei, os resultados de dar e de compartir, eles comem ser terem dado. A mácula do egoísmo toma conta das suas mentes.

Se os seres soubessem aquilo que o Grande Sábio disse, que o resultado da generosidade produz tão grande fruto, então, subjugando a mácula do egoísmo com a mente luminosa, eles dariam no momento apropriado para os nobres, onde uma oferenda produz grandes frutos.

Tendo dado comida como uma oferenda para aqueles dignos de oferendas, muitos doadores, quando aqui falecem, do estado humano, vão para o paraíso.

Eles, tendo ido para o paraíso, regozijam-se, desfrutando dos prazeres sensuais, sem egoísmo, eles participam do resultado da generosidade.

${ }^{221}$ BUDA, Gotama. Dana Sutta (Generosidade). Itivuttaka 26 O Itivuttaka, o quarto livro do Khuddaka Nikaya que consiste de 112 suttas curtos divididos em quatro grupos, recebe esse nome da afirmação no começo de cada um dos discursos: isto (iti) foi dito (vuttam) pelo Abençoado (Bhagavata).

Essa coleção como um conjunto é atribuída a uma discípula leiga chamada Khujjuttara, que trabalhava no palácio do Rei Udena de Kosambi como criada de uma das suas rainhas, Samavati. Como a Rainha não podia sair do palácio para ouvir os discursos do Buda, Khujjuttara ía no lugar dela, memorizava aquilo o que o Buda dizia e depois regressava ao palácio oara ensinar a Rainha e as suas 500 damas de companhia.

Pela sua dedicação, o Buda mencionou que Khujjuttara era a principal das suas discípulas leigas em termos de aprendizado. Ela também foi uma professora muito eficaz: quando os apartamentos íntimos do palácio foram mais tarde consumidos num incêndio, matando a Rainha e as suas acompanhantes, o Buda comentou (no Udana VII.10) que todas aquelas mulheres haviam realizado pelo menos o primeiro estágio da iluminação. in http://www.acessoaoinsight.net/sutta/udana.php 
10 - $\underline{\text { ANEXO }}$

DA EVOLUÇÃO DO PENSAMENTO DE SIGMUND FREUD DURANTE A PAX BRITANNICA E OS 20 ANOS DE CRISE (1919-1939) OU O MUNDO DA VIDA DESCOBRE O INSTINTO DE MORTE

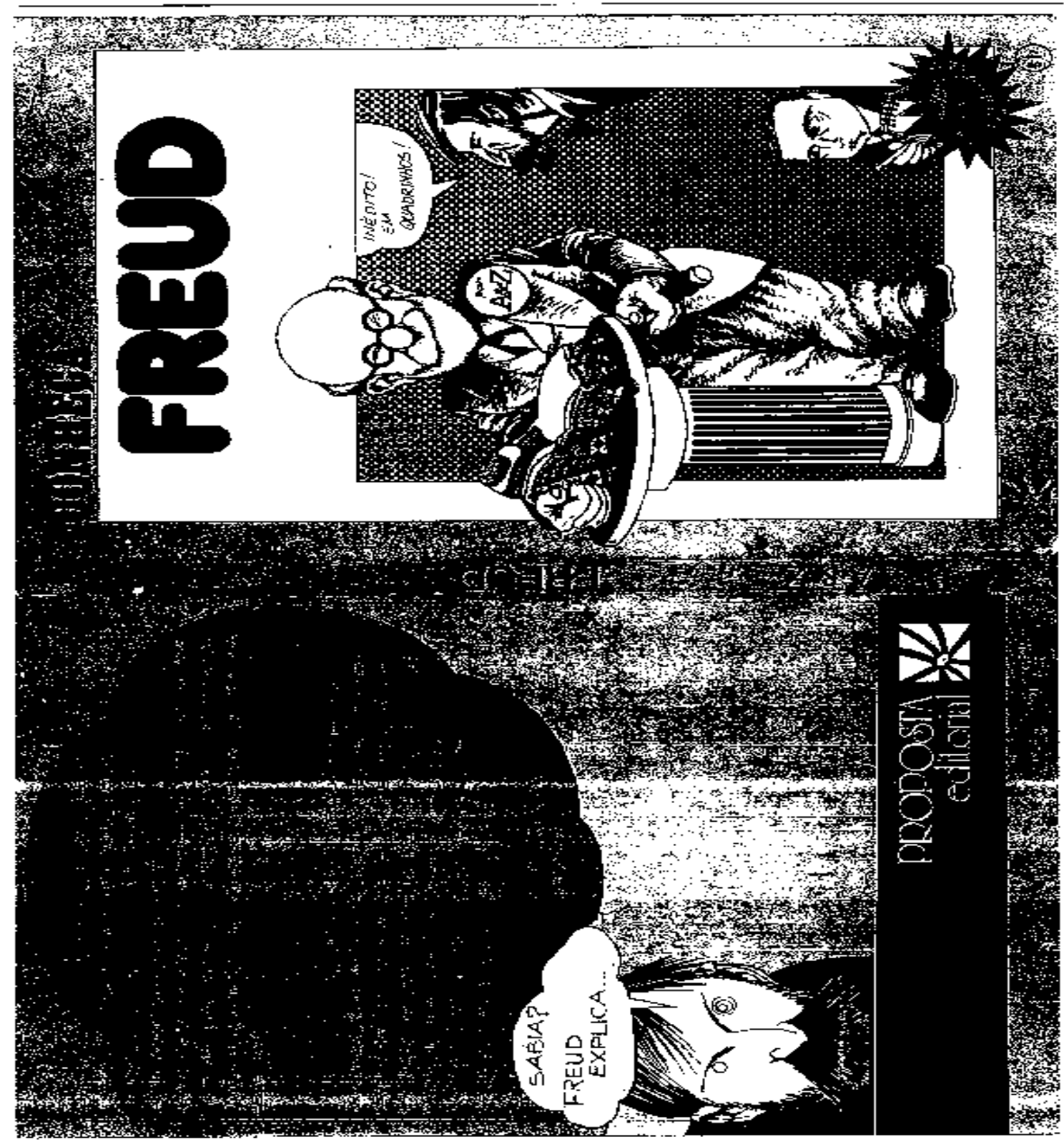

222

${ }^{222}$ APPIGNANESI, Richard(texto), ZARATE, Oscar (ilustração). Conheça Freud.Proposta Editorial Ltda, 1979, São Paulo. 
F'oud ditla que o gonho funcinta comn um madalo, am minlalura, ge ume teuroso.

Mas se sonhar a normal, como pode en:äo procuzir sinais de compertamento neurot|co?

Vajemos álguns pass.js que deram ä Fraud, pele pri:neir a vaz, evidéncias sotore ar ldsisa do inconzciẹnte.

Vimos como o conteúdo manltesto da 50 r.hic expseasa, irdiratamente, um deseio sexual latente com a ajuda oe siknolos. A csta "substituiçăo" de um dezejo, por um objeto marlfosis, Freud chatou de deslocamento.

Tarrbem na netrose, da-se um deglocatnenio.

A energis emcolongl de deacocacta da representaça patogénica (tc orlgem doentia), pars os eintoma. E lero ocores incronsclentemente.

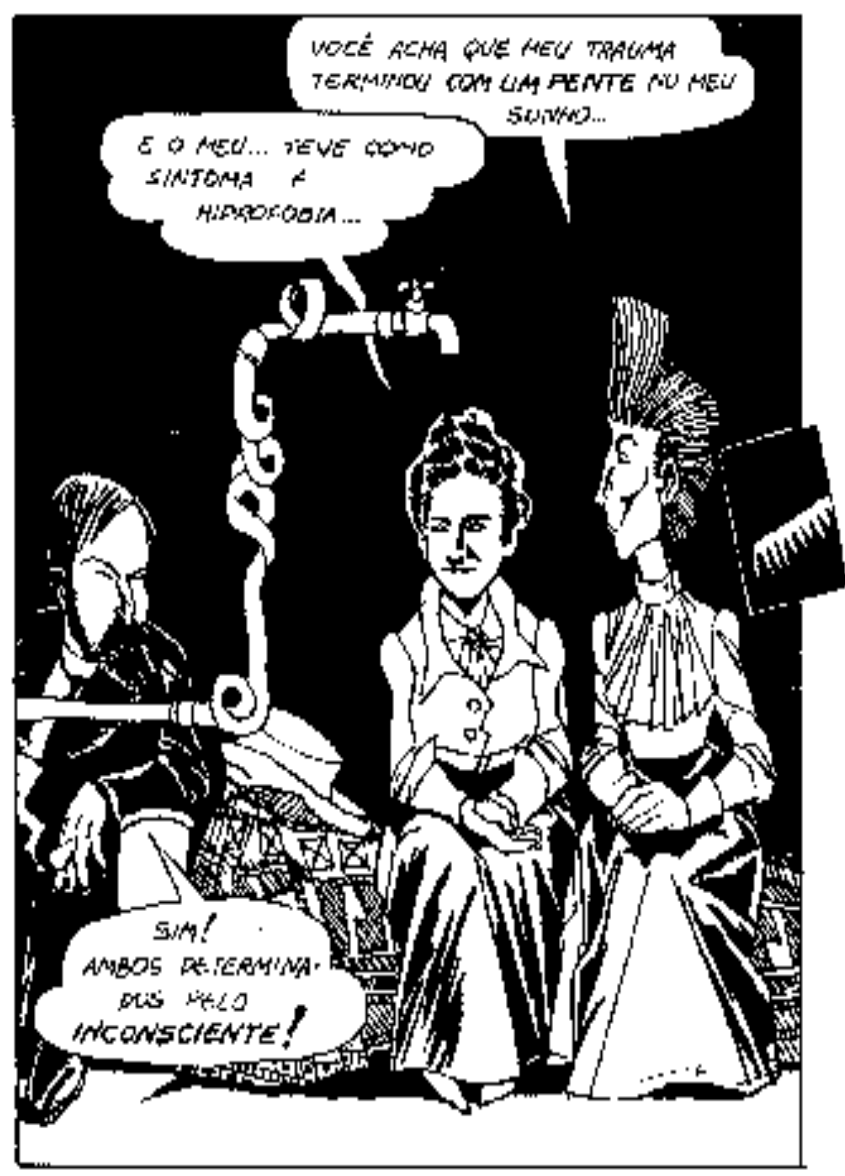

$\operatorname{sen}$ 
E passamos oniăo à segunda descoberte de Freud, que revolucín iou o que sabiamos sobte a constiáncis humana.

\section{O INCONSCIENTE}

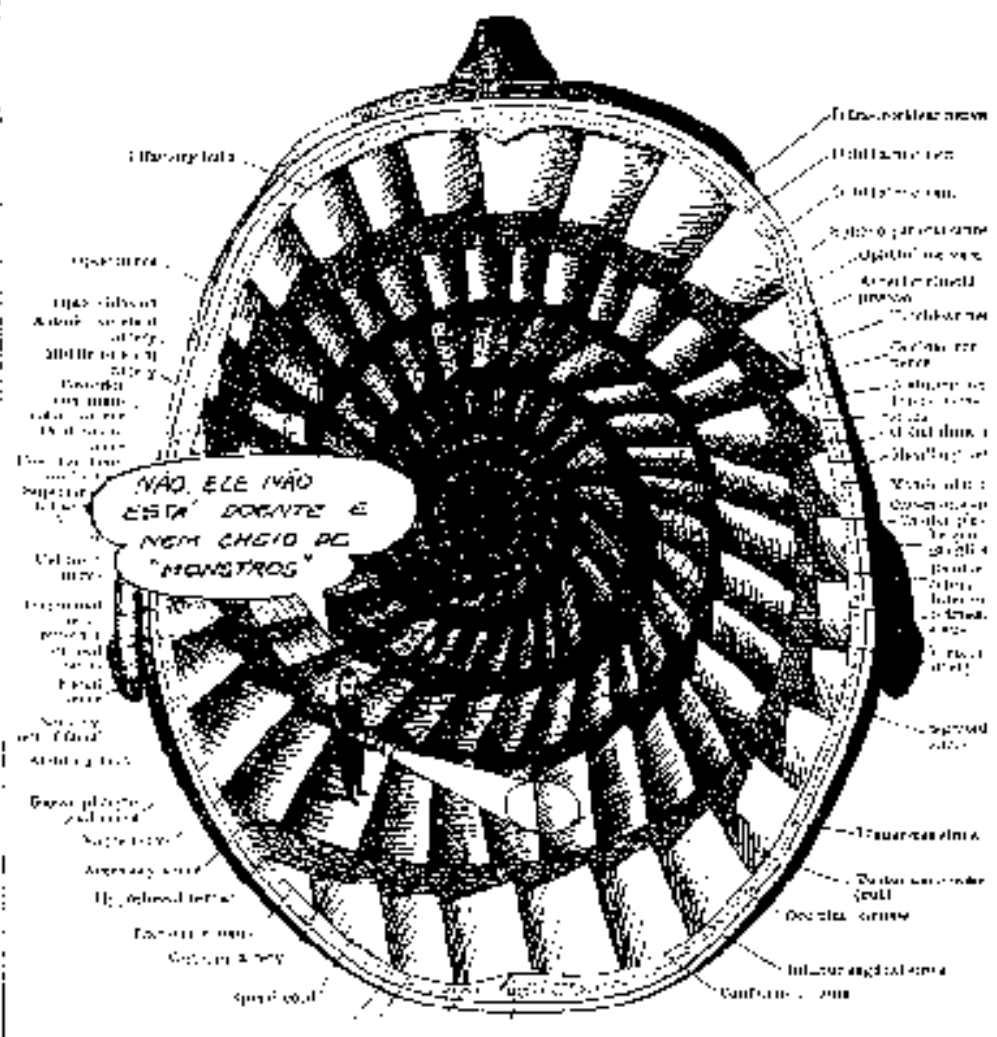

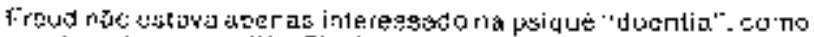
geraimnnlo sa acredita. Eledesenvolvsu uma losria jeral da psiziuè

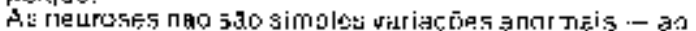

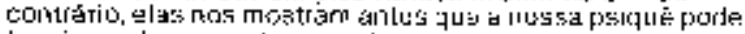
lurırjicrer de uma outia marienir,

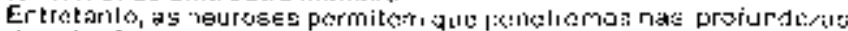

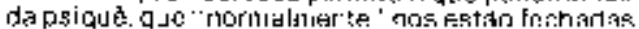


Freud dividla a psiq Jڤ em dusa partes;

1. O pró-consciente, que abares todas an lifias o lemtranças, que podesm se 10rnar conscienles.

2. O incorschente que aloja todas as necessitades, desolos e In stintos, na maloria sex jais, a algumas vezes de naturaza detirulive

Os desedos inconscientes recebem energia cos instint:

firlcar basicos.

Freud chamou a satlsfaçă dos desejos degtes impulgos primários de..

\section{O PRINCIPIO DO PRAZER}

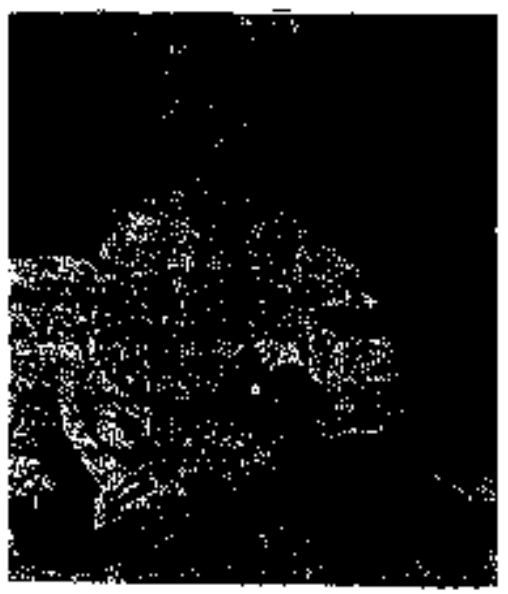

Q principio do prazer pode, lacilmente, ir de ereontro a conflilos com as aliuntader rionscile letes da paique que se ocupam em evliar o parigo, em se adequar a feslideje e go comportamento civilizado C préconsciente opera om uma forma de "persar." mais conirolada, disciplingda. Ele leva em consideracto as exigencias da iéalidade e pode tulerar um adlamentodz. antislaças dos instlnos.

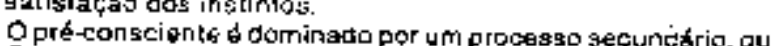
Freud thamou de:

O PFINCIPIO DA REALICADE

Cer1a vez, F reud at Itmou gue a forma mass cirli zada do principto da Fealidiade seria... a CIENCIA 
Q que asontece quando a psiquéé dominada pelo proceaso primario de satıstaçăo dos in atintos. isto ê, pelo Principio Jo Prazer?

Obearvemos um cxchplo nón-saxual; um horem faminto esta perdirlo na floresta, sem comida..

Se a iddia primfiria ce

"romida " dombiflar o homern. ela sera incapaz de pénser er. cotho satigfazer sua fomb.

Mas quando p’oual 白e o processo secuncario, o do Priracipio de Realidade, ele prode "эsquecer" a comide por algurm tempg, vara pensa em comroconsegulila.
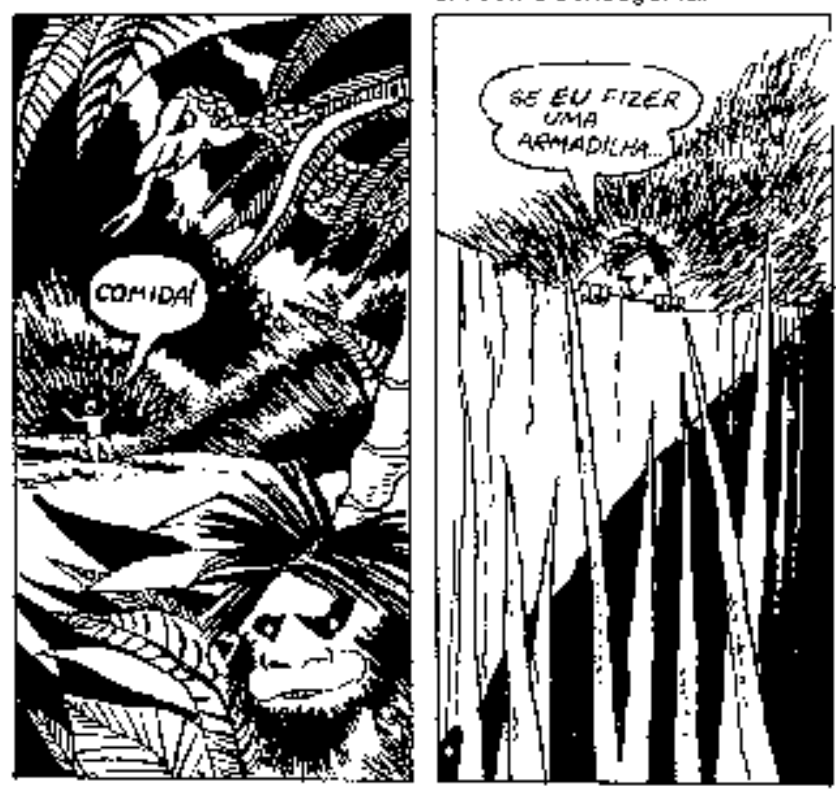

As ideias do processo prlmál ic utédonninami p infonsc er te sāo impilsivas, tesorganlzad ss a llbgicos.

Por isiso, segundu frewh, topo o pensaman to huthanc s, uli parte. um comaromisso, E, em parte. ura iurlitu wulru o pré-consciente $\mathrm{c}$ inconecente. 


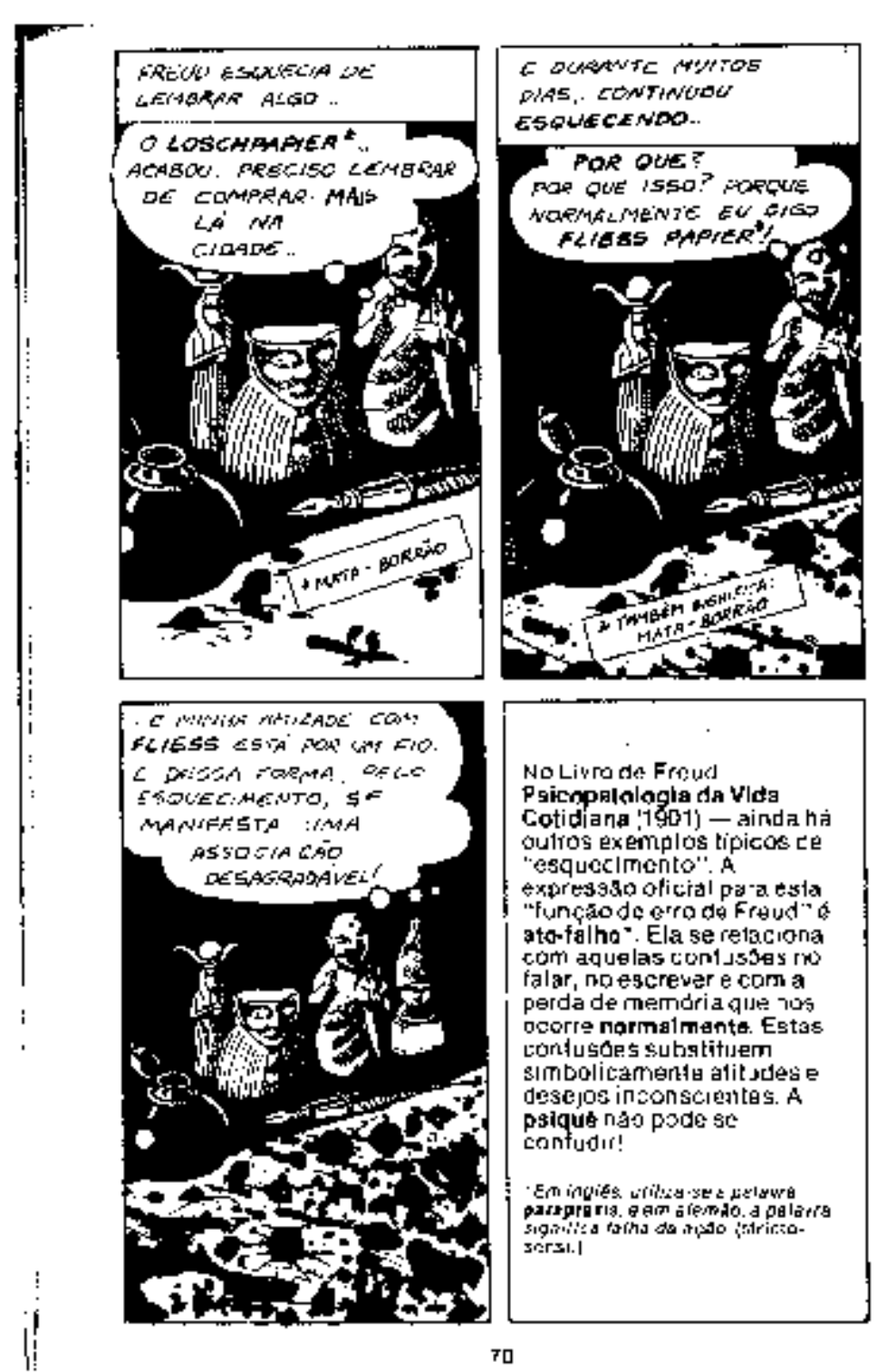


Em 1905, Freud publica os seus ThËS ENSAIOS SOARE A SEXUALIDADE.

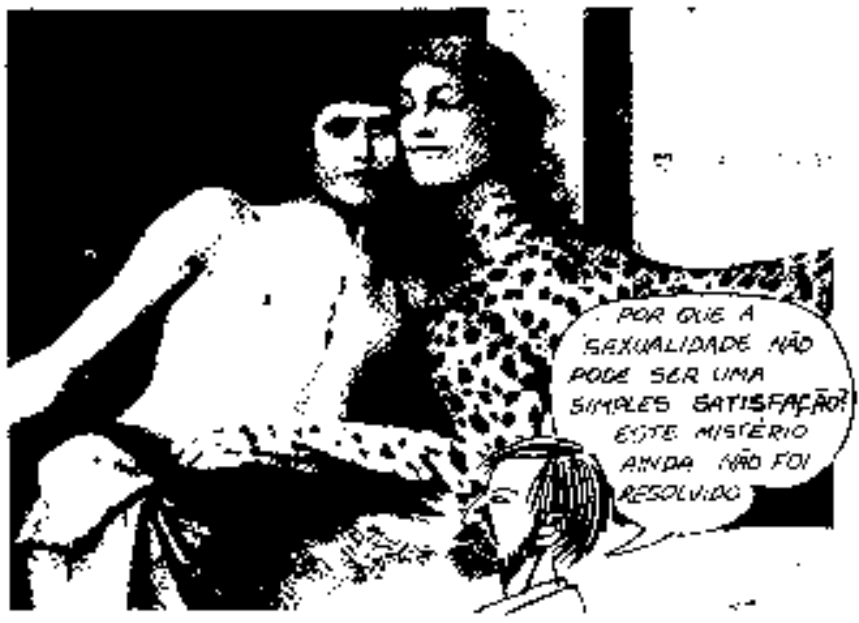

O sirmples prazer sexusa nuo o tao si nples. Comoe :rateda, en gyeral. a sexualicace?

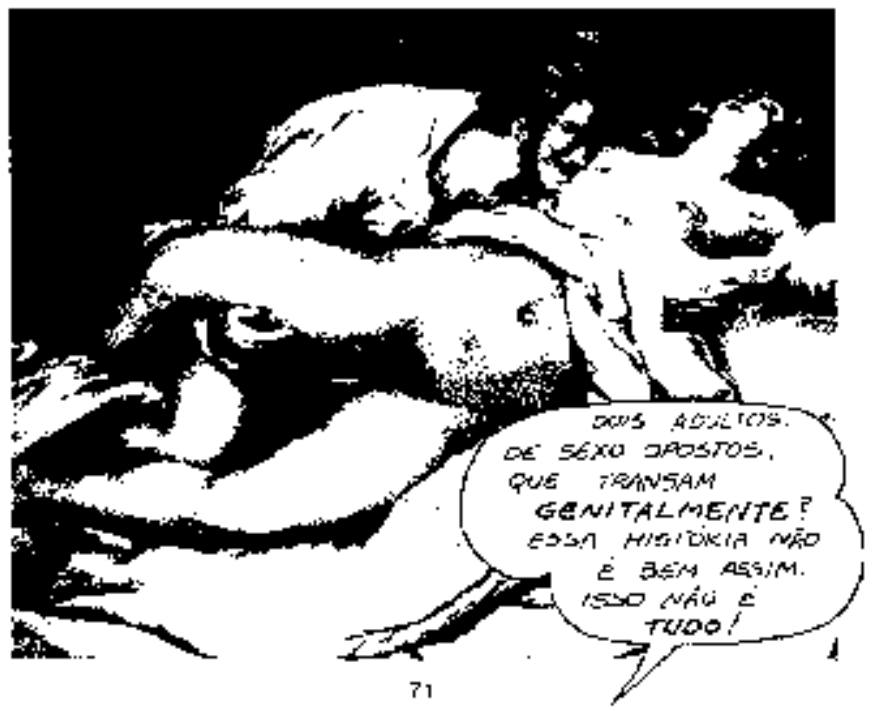




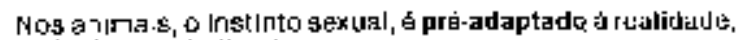
tologlcaltisile linádo.

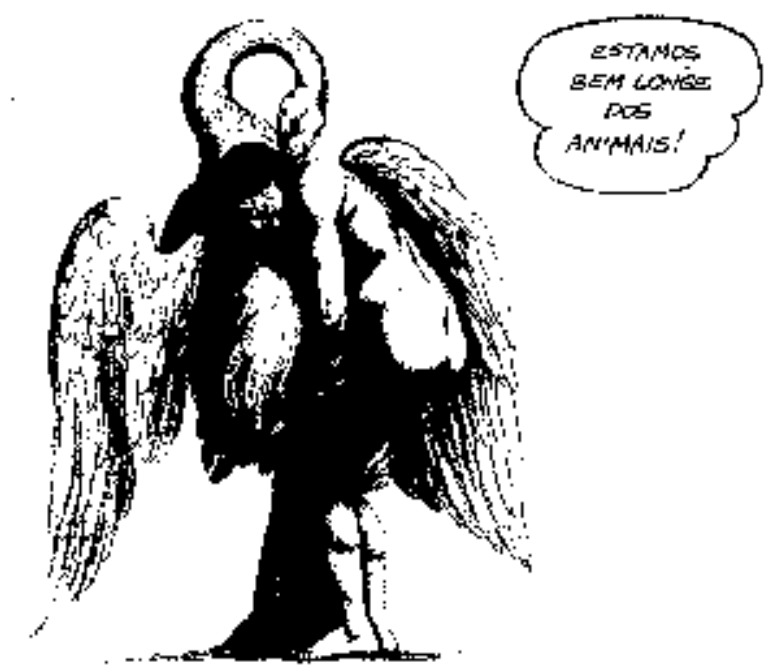

"Somente in ser humallo a rida sexül percored dais momen1os, Juriantc a infancia e na puberd eulte. E istse conhecido somente pelo ser humano, o que naturalmente.

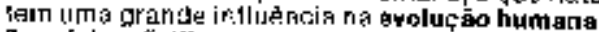
(hominizaçă".

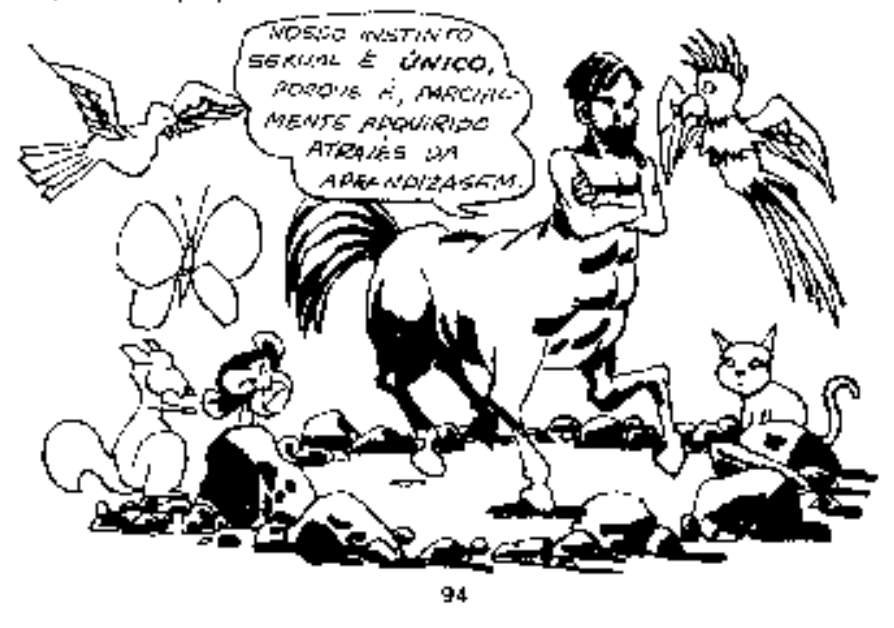




\section{SABER SIGNIFICA SAÚDE?}

Nos somos ? quando nosso in 1peto de saber năo ériilide.

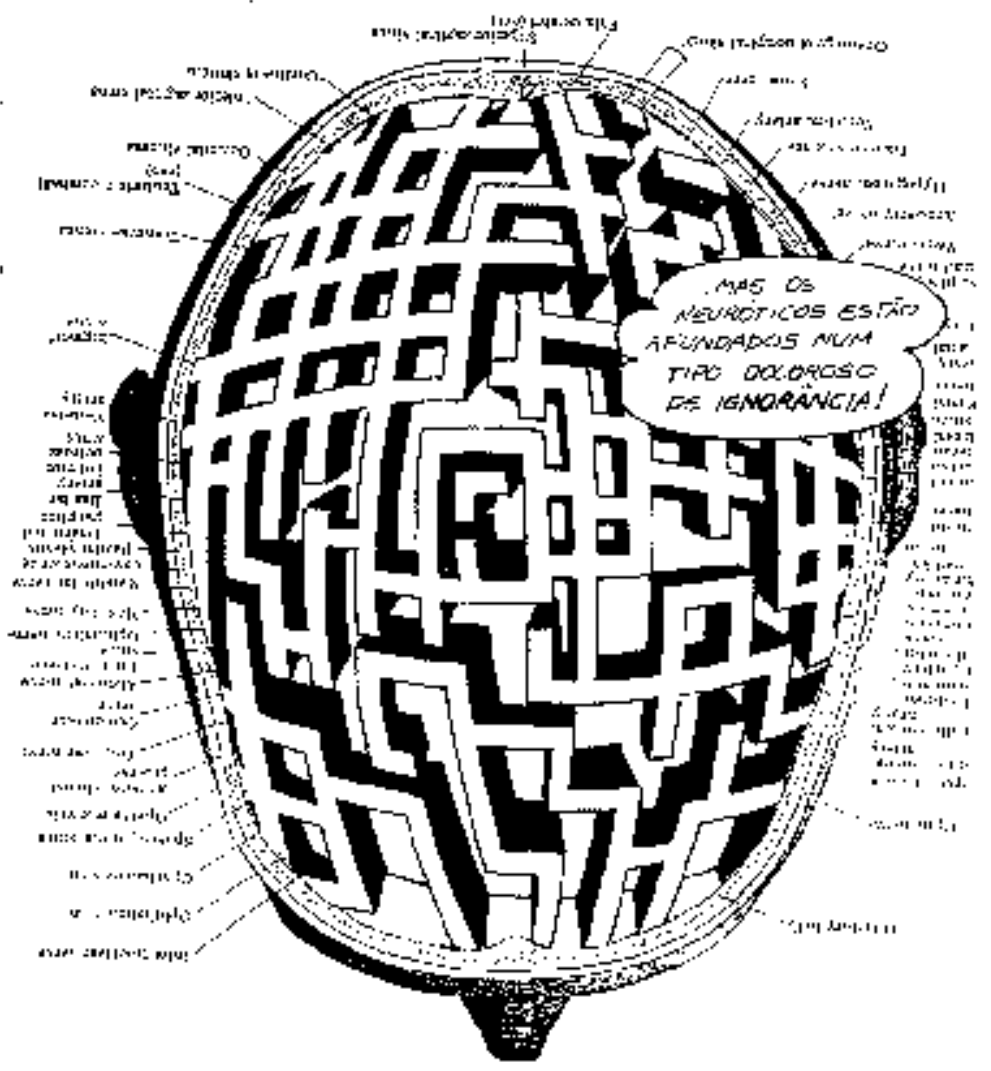

Qual è a "ignoráncla Jos neurotirus?" A.lguma colsa os impede

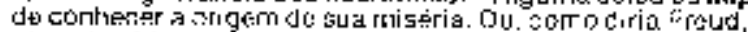

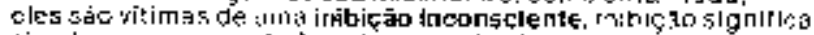
sirrplesmen:e um relrsimento no conhacimerito da o'gen ito protilema, que determina n mbdels de somportamento rigido de umenturblin.s. 
Freud buscou a xigem dos problemas neurathços na inlancla. Alputia coisa pode ler saído errado no processo de

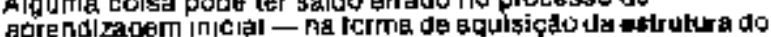

aprendlzagem In|cial -

A日 coisas so pasegm a日sim:

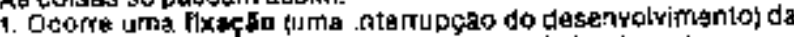
libido em uma determınaoa tase da Intancía icfal, anal,

$$
\text { eqdipianal. }
$$

2. isto pode levar a uma maresnbo (retarno) a fase "|lxada", o que lave adlierentes farmas de heurose.

Os neuróticng ác, Heralmente, "enlätados", "cegog". Em uma fixaote gnat, por exemplo, o cormponamento obsesslyo mostrase en todes as toms posg|vels.

O avaro obsessio pela ordem trabalhos incompletos

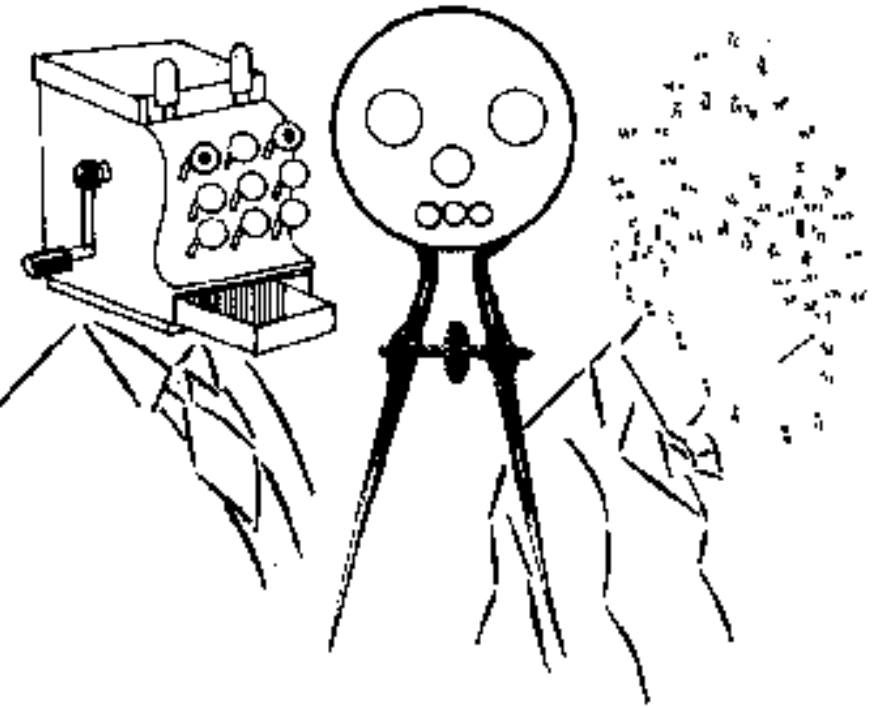

Gorosoienlemente, a avarz asld ocupado om conservar c set dintiolo, Mas Inconsclentements, els "segura" o dinhairo como valar stmbolico, 550 ciado aos saus excrementos 19 tase anal. ldeias obsessiugs subsistem ainda que náfo colrncidam cọm a parte conscienle da personalldade. 


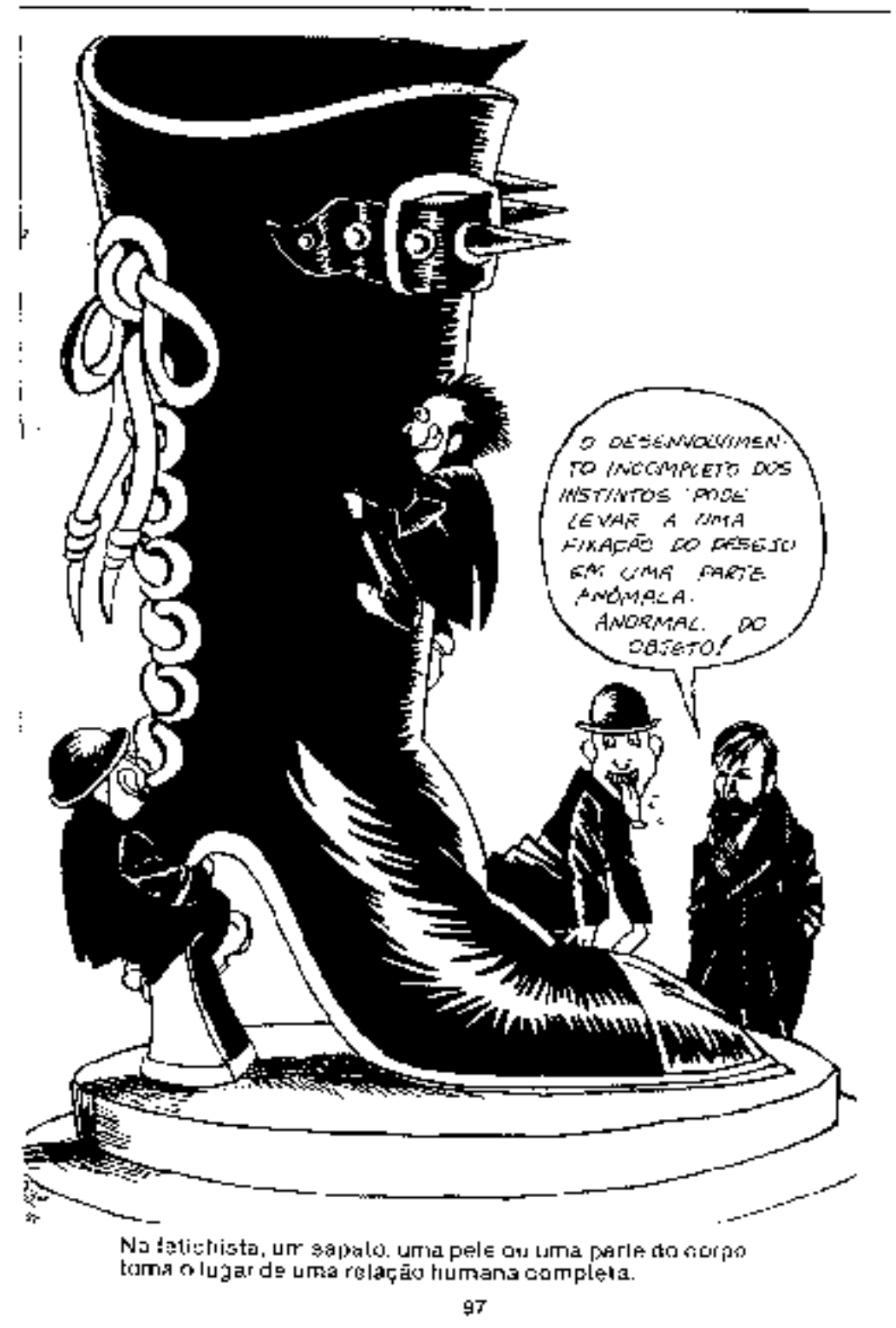

242 
Esta hosilldade é combreers/vel. Com a sud tercalr contruista

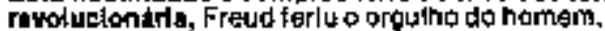

\section{it RGVOCOFAO}

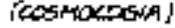

A TERRA IE POETANTO A Hermantosar) NASO E

O GGNTRO

DO UNGERSO.

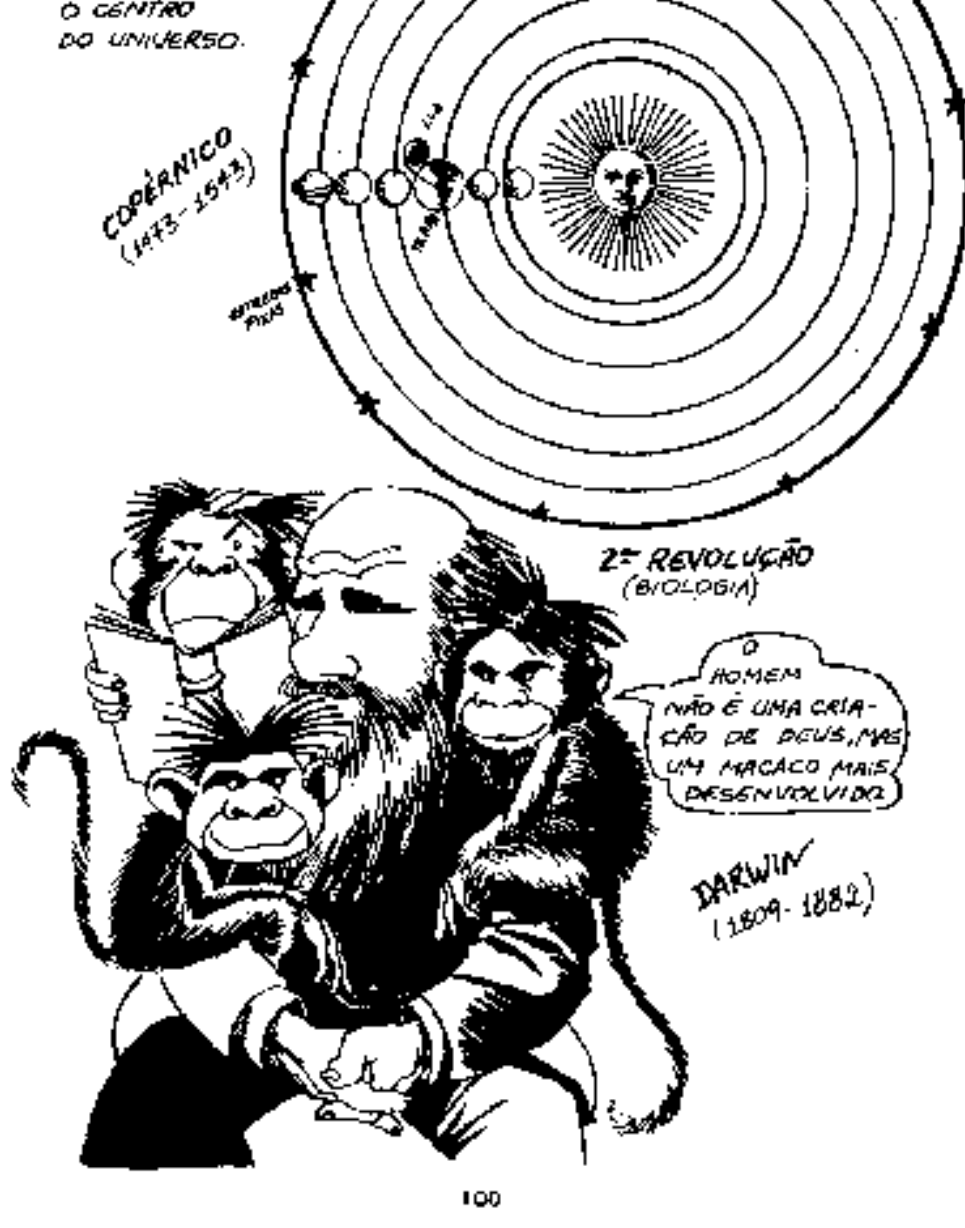




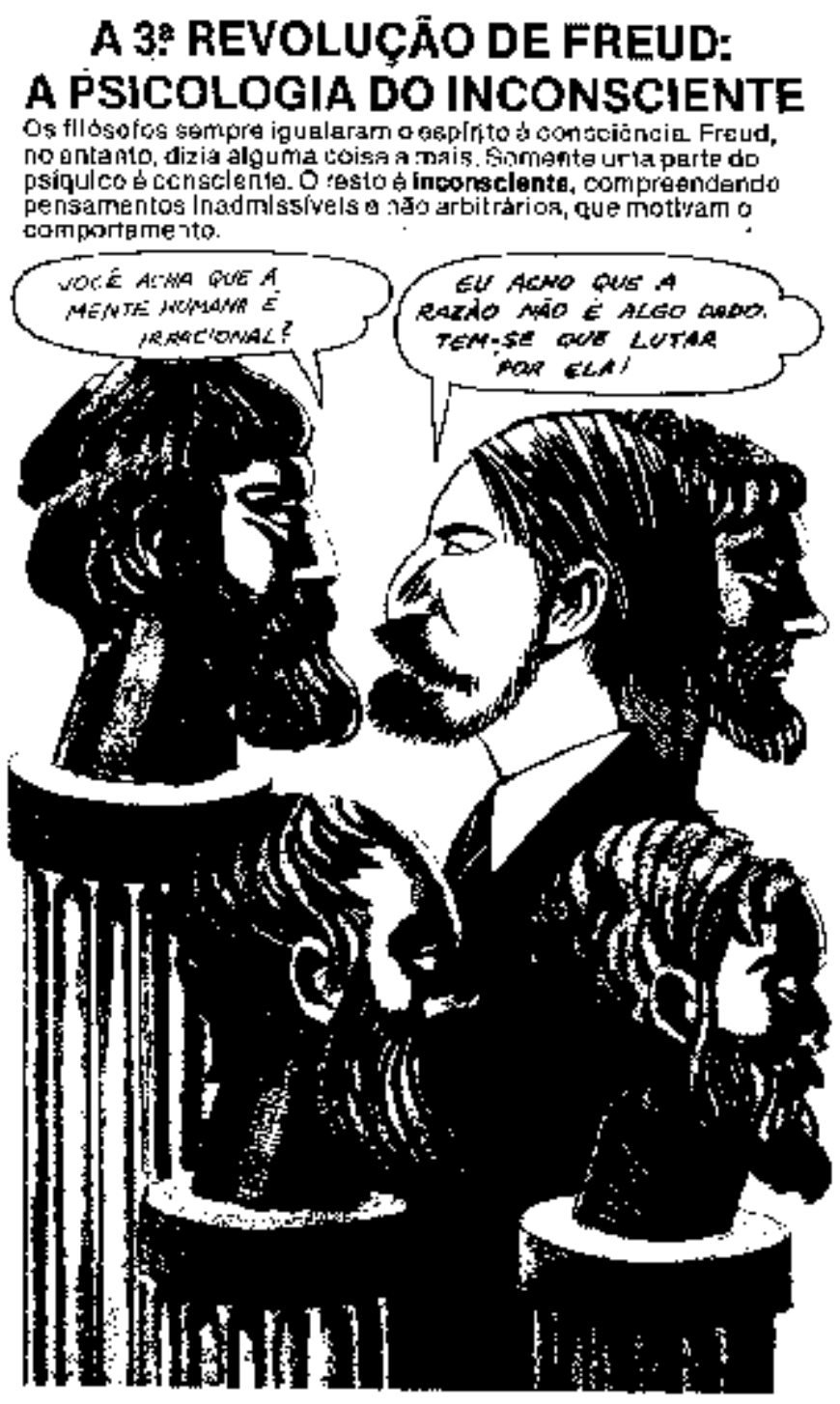

101 
A CAMINHO DO' 'INSTINTO DE MORTE' (1955-1919)

Freud cor:inuava a procurar por uma teorla satlsiatcria sobre og confilios Instintlros.

Drarip 1895 ele pensaya que o comportamenio humano tinha como basa duas tendenclas contrarlas: o principlo do prazer e principio de realindade. Estes principios estar am 1.07dos ao sistema nerroso.

1. O principlo do prazer eur prosesgo primário, no sentido de que

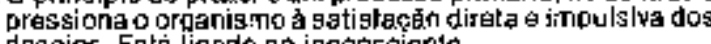
Jesejos. Enka ligedo ad inconsciente

2. 0 p rinclpiz da realidacte perrnliti ao organismo tolerar un

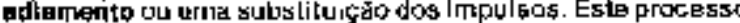

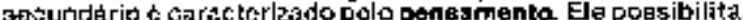
em certa medida, a suspe nsho rins impul gos bexuais e desvla sua enereia para o pensamer lo pafa o trabahto e para diversato.

Ofamoso ritecanismtó de subF maçấo depende Jo princlpio da realidade; ao cortrario do çe se pansa comurrerte, néco consiate em urta repressado dos jmpulsos sexuais, mas eri tain encaminhamanto da energia libidinal a urrąa adequaşa necessárla a realidade.

Frewd reconhece sgora que o principio do prazer e o prlncipia da reatidade náo gáo verdade iramenle antagóniros, pais os dais

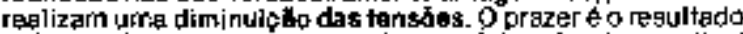
psiquico do descarregamento do uma determinada quantia de excitaçác, estlmulos ou tersas produzida no orgănismo. Oprincipio isa realldade chege ao meamo resuatado, com a ajuda deum proceseo de adlamento a de refreaniento - ó prazor.

Mas agora, Freud pergun lava:

como a repetic in dg uma experiancia desadgradave se errcaixa cun a pirrifipiu de $\mu^{-2}$ detr

TODO COMPORTAMENTO ESTÁ A SERVIÇO DA REDUÇÃO DETENSÄO 


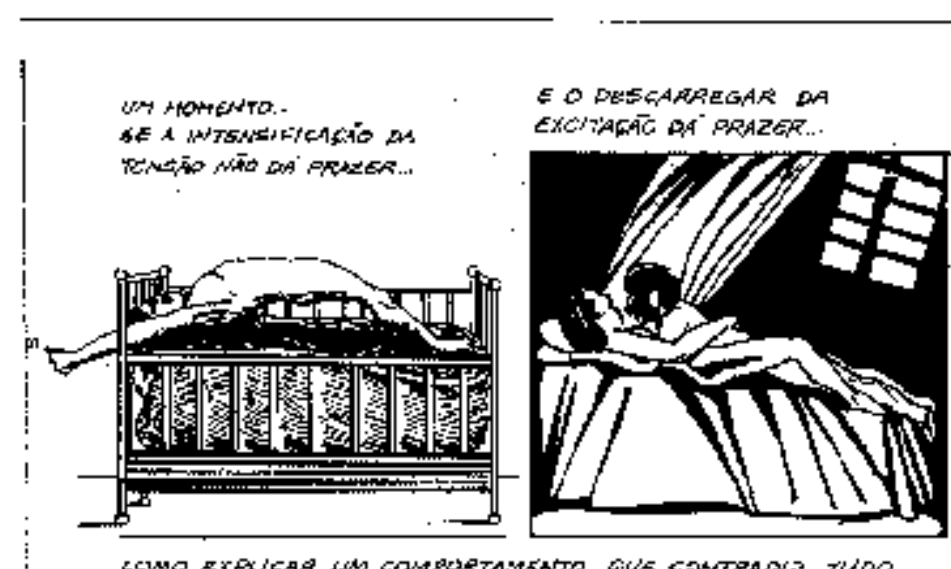

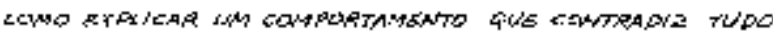

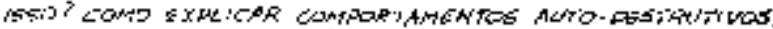
Camo $I$ MASOLU/SMO?

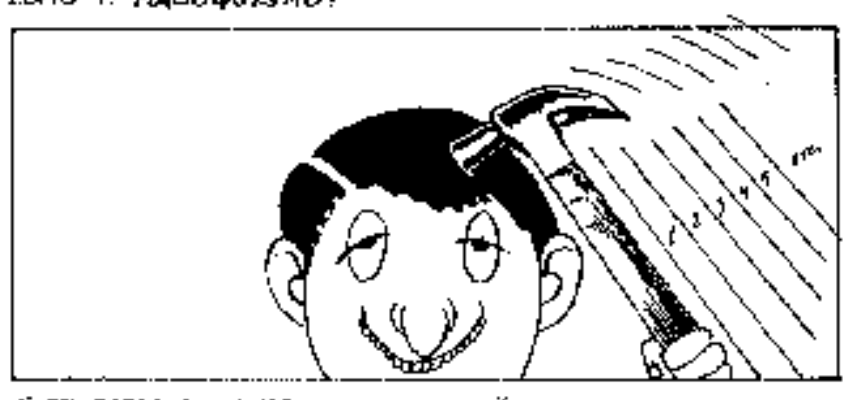

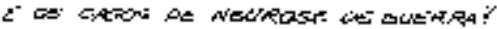

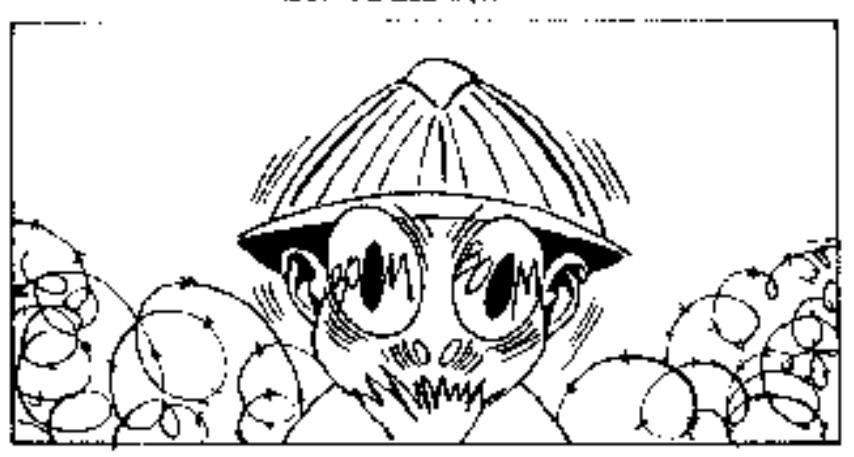

145 
Em novembro de 1919, no King's College, em Cambridge, John Maynard Keynes, escreveu o seguinte, no prefácio de sua obra As Consequências Econômicas da $\mathrm{Paz}^{223}$ :

O AUTOR deste livro esteve associado temporariamente ao Tesouro inglês, durante a guerra, tendo servido como seu representante oficial na Conferência de Paz de Paris até 7 de junho de 1919; substituiu também o Chancellor of the Exchequer no Conselho Econômico Supremo, deixando essas funções quando ficou evidente que não se poderia esperar uma modificação substancial na minuta das condições da paz. As razões da sua objeção ao Tratado, e na verdade a toda a política da conferência no referente aos problemas econômicos da Europa, ficarão claras nos capítulos que seguem, de caráter inteiramente público e que se baseiam em fatos conhecidos em todo o mundo. (grifos nossos)

No capítulo 1, Keynes introduz sua opinião textualmente:

Uma característica marcante da humanidade é a capacidade de se adaptar ao meio. Poucos dentre nós percebem, com convicção, a natureza intensamente incomum, instável, complexa, temporária e não confiável da organização econômica da Europa Ocidental na última metade do século.

Achamos que algumas de nossas vantagens posteriores, das mais peculiares e temporárias, são naturais e permanentes; pensamos que é possível contar com elas, e, com base nesta premissa, fazemos os nossos planos. Sobre Alicerces frágeis e terreno arenoso, planejamos o aprimoramento da sociedade e criamos nossas plataformas políticas; seguimos o rumo das nossas

${ }^{223}$ KEYNES, John Maynard (1883-1946). As Consequências Econômicas da Paz(1919), tradução de Sérgio Bath; prefácio Marcelo de Paiva Abreu. São Paulo, Imprensa Oficial do Estado, Brasília, Editora Universidade de Brasília, 2002. Coleção Clássicos IPRI, v.3. 
animosidades e ambições particulares, e nos achamos com uma margem suficiente para promover o conflito civil na família europeia, em vez de mitigá-lo.

Movido por ambição insana e autoestima desastrosa, o povo alemão derrubou as bases sobre as quais todos vivemos e construímos, mas os porta-vozes do povo francês e do inglês correram o risco de completar a ruína iniciada pelo Estado germânico com uma paz que, levada a efeito, deverá prejudicar ainda mais, em vez de restaurar, a organização complexa e delicada já prejudicada e tornada vulnerável pela guerra, graças à qual os europeus podem empregar-se e viver.

$\mathrm{Na}$ Inglaterra, o aspecto aparente da vida não nos ensina ainda a sentir que chegamos ao fim de toda uma era. Estamos preocupados em recolher os fios de nossas vidas onde os deixamos cair, com uma única diferença: muitos de nós parecemos bem mais ricos do que antes. Onde antes da guerra gastávamos milhões, aprendemos, neste momento, a gastar centenas de milhões, aparentemente sem qualquer problema. Naturalmente, não exploramos, ao máximo, as possibilidades da nossa vida econômica. Por isso, esperamos não só um retorno às comodidades de 1914, mas uma ampliação e intensificação desses confortos. Todas as classes fazem planos: os ricos para gastar mais e poupar menos, os pobres para gastar mais e trabalhar menos, no entanto, talvez só na Inglaterra (e nos Estados Unidos) seja possível ser tão inconsciente. No continente europeu, a terra move-se sem que ninguém perceba. Não se trata apenas de uma questão de extravagância ou de "problemas trabalhistas", mas de vida e de morte, de fome e de sobrevivência, as tremendas convulsões de uma civilização moribunda. (grifos nossos) 
Para quem viveu em Paris a maior parte dos seis meses que sucederam o armistício, uma visita ocasional a Londres era uma experiência estranha. A Inglaterra ainda se encontra fora da Europa, cujos tremores silenciosos não a alcançam. A Europa está afastada e a Inglaterra não é parte do seu corpo e da sua alma. Mas a Europa continental é una: França, Alemanha, Itália, Áustria, Holanda, Rússia, Romênia e Polônia vibram juntas - têm uma só estrutura e civilização. Floresceram juntas, juntas foram sacudidas por uma guerra em que nós, ingleses, a despeito da enorme contribuição e dos grandes sacrifícios que fizemos (embora em menor grau do que os Estados Unidos da América) ficamos de fora economicamente. Assim, esses países podem decair juntos. Este é o sentido destrutivo da Paz de Paris. Se a guerra civil europeia deve terminar com a França e a Itália usando, abusivamente, seu poder momentâneo de sua vitória para destruir a Alemanha e a Áustria-Hungria, que jazem prostradas, estão convidando a sua própria destruição, por estarem tão profunda e indissoluvelmente ligadas às suas vítimas, por vínculos econômicos e espirituais ocultos.

De qualquer forma, um inglês que participou da conferência de Paris e durante aqueles meses pertenceu ao Conselho Econômico Supremo das Potências Aliadas, deveria tornar-se um europeu nos seus cuidados e na sua opinião (uma experiência nova para ele). Ali, no centro nervoso do sistema europeu, suas preocupações britânicas em boa parte desapareceriam, e ele seria perseguido por outros espectros, mais assustadores.

Paris foi um pesadelo, e todos estavam envolvidos por uma atmosfera de morbidez. Um sentido de catástrofe iminente assombrava o frívolo cenário: a futilidade e mesquinharia do homem diante dos grandes eventos que o confrontavam; o significado ambíguo e o irrealismo das decisões; a ligeireza, a cegueira, a insolência, os gritos confusos de ira - havia 
ali todos os elementos da tragédia antiga. Sentado ao lado das decorações teatrais dos salões oficiais franceses, podia-se especular, se os rostos peculiares de Wilson e Clemenceau, com sua cor fixa e caracterização imutável, eram ,de fato, rostos, e não as máscaras tragicômicas de algum estranho drama ou de um espetáculo de marionetes.

Os procedimentos, em Paris, tinham todos esse ar de extraordinária relevância e, ao mesmo tempo, de pouca importância. As decisões tomadas pareciam prenhes de consequências para o futuro da sociedade humana; contudo, o contexto insinuava que as palavras não tinham peso - eram fúteis, insignificantes, sem efeito, dissociadas dos fatos. Sentia-se, fortemente, a impressão, descrita por Tolstoy em Guerra e Paz, e por Thomas Hardy em Os Dinastas, de acontecimentos que caminhavam para a sua conclusão, sem sofrer qualquer influência das celebrações dos estadistas reunidos em conselho:

\section{O Espírito dos Anos}

Vê como essa gente enlouquecida Abandona toda a visão larga e toda a contenção Em troca de uma negligência imanente.

Nada resta, além da vingança entre os fortes e Entre os fracos uma ira impotente.

\section{Espírito da Piedade}

Que dá força a essa vontade

Para agir de forma tão insensata?

\section{Espírito dos Anos}

Já te disse que é inconsciente, ela opera sem julgar, como um ser possuído. 
Em Paris, onde os que trabalhavam no Conselho Econômico Supremo recebiam, quase que a cada hora, relatos sobre a miséria, a desordem e a desorganização de toda a Europa Central e Oriental, nos países aliados como nos inimigos, e ouviam dos representantes financeiros da Alemanha e da Áustria o testemunho da terrível exaustão dos seus países ${ }^{224}$, uma visita ocasional à sala quente e seca do Presidente da Casa, onde os quatro cumpriam o seu destino em uma intriga árida e vazia, só aumentava esse sentido de pesadelo.

Em Paris, os problemas da Europa eram terríveis e clamavam por solução, fazendo que o retorno ocasional a Londres, que parecia não se preocupar com eles, fosse um pouco desconcertante. Porque, em Londres, esses problemas eram muito distantes, e só nos ocupavam-nos de nossos próprios problemas, menos graves. Em Londres, acreditava-se que Paris estava criando uma grande confusão, mas não havia muito interesse pelo assunto. Dentro desse espírito, o povo inglês recebeu o Tratado ali

${ }^{224}$ A Alemanha transferiu 8 bilhões de marcos ouro ( $£ 400$ milhões) até maio de 1921 , equivalentes a $20 \%$ da renda nacional alemã em 1921, mas muito abaixo do valor de $£ 1$ bilhão de pagamentos interinos estabelecidos na conferência de Versalhes....

A Alemanha pagou apenas $75 \%$ das reparações devidas no ano, a partir de maio de 1921, e continuou pagando muito aquém dos níveis fixados em janeiro de 1922, o que levou à ocupação do Ruhr pelos franceses e belgas em janeiro de 1923. Seguiu-se um período de sérias perturbações internas em 1923-1924 bem retratadas pela hiperinflação, só interrompido quando foi possível com um acordo entre industriais, governo alemão e aliados, culminando na estabilização monetária alemã e na negociação do Plano Dawes em 1924. Foi concedido um importante empréstimo à Alemanha e as reparações foram muito reduzidas, flutuando entre 0,8 e 2 bilhões de marcos entre 1924 e 1928, cerca de $10 \%$ dos pagamentos previstos inicialmente só para o serviço da primeira tranche.

De fato, entre 1925 e 1928, os empréstimos dos EUA à Alemanha superaram folgadamente os pagamentos de reparações por parte da Alemanha. De uma forma indireta tornou-se concreta a idéia de Keynes que, de alguma forma, os EUA pagariam a conta. Com a retração de capitais norte-americanos já em 1928, os pagamentos de reparações foram mais uma vez reduzidos por meio do Plano Young de 1929, que também incluiu um grande empréstimo à Alemanha. Com a moratória Hoover de 1931, que afetava tanto reparações quanto empréstimos interaliados, os pagamentos seriam interrompidos. Os pagamentos totais da Alemanha entre 1918 e 1931, somando valores correntes, totalizariam 22,9 bilhões de marcos (pouco mais de $£$ 1,2 bilhão), 17,3\% das reparações fixadas inicialmente.

Mas, razão ou pretexto, os pagamentos de reparações, somados à exploração pela direita na Alemanha de que a derrota de 1918 deveu-se à "facada nas costas", isto é, à traição da esquerda na frente doméstica, alimentariam a sede por novo acerto de contas em 1939. in Prefácio à edição brasileira de As consequências Econômicas da Paz, por Marcelo de Paiva Abreu. 
negociado, mas não o leu.

Este livro foi escrito sob à influência de Paris, não de Londres; escrito por quem, embora inglês, se considera também um europeu, e, em razão de uma experiência recente muito vívida, não pode desinteressar-se pelo desdobramento do grande drama histórico destes dias, que destruirá grandes instituições, mas poderá, também, criar um novo mundo.

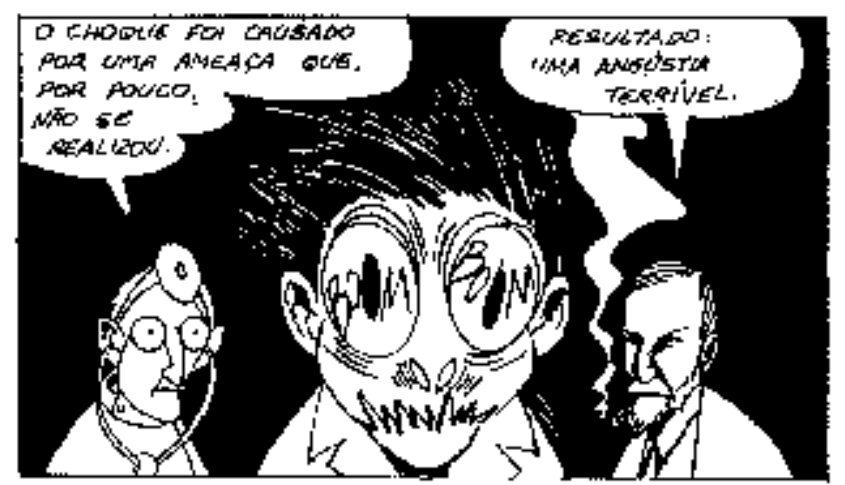

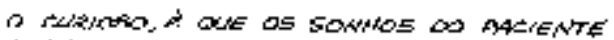

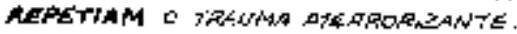
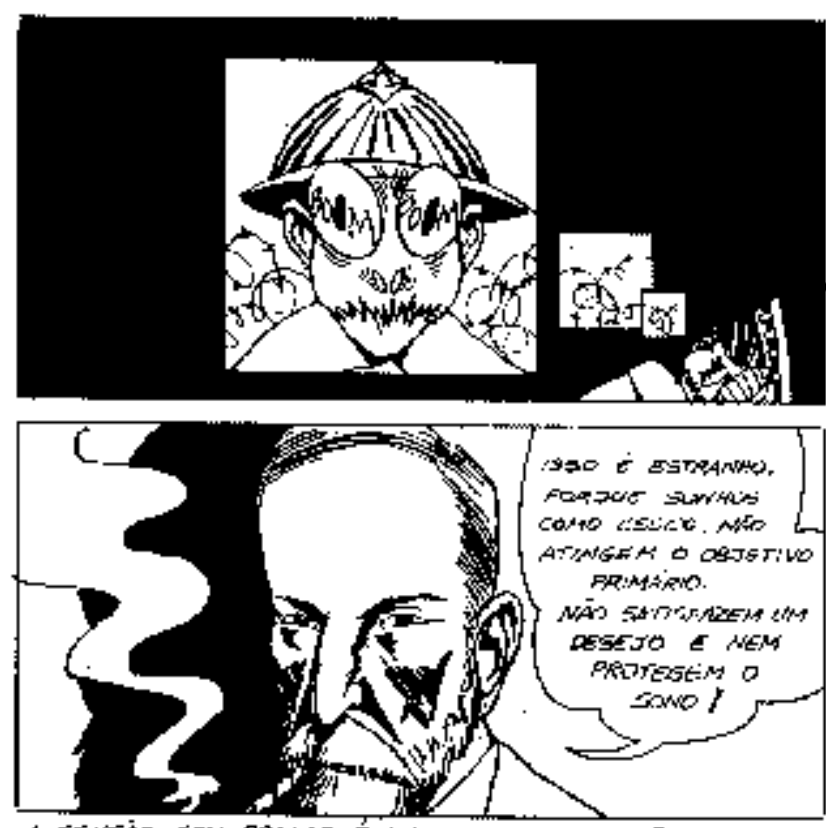

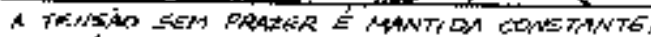
ATEAVES AA REDRTIFĀ

$14 E$ 


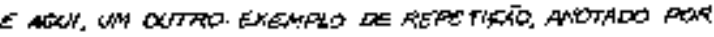
FRAS:

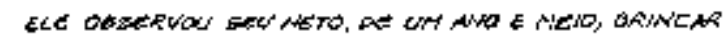
स.

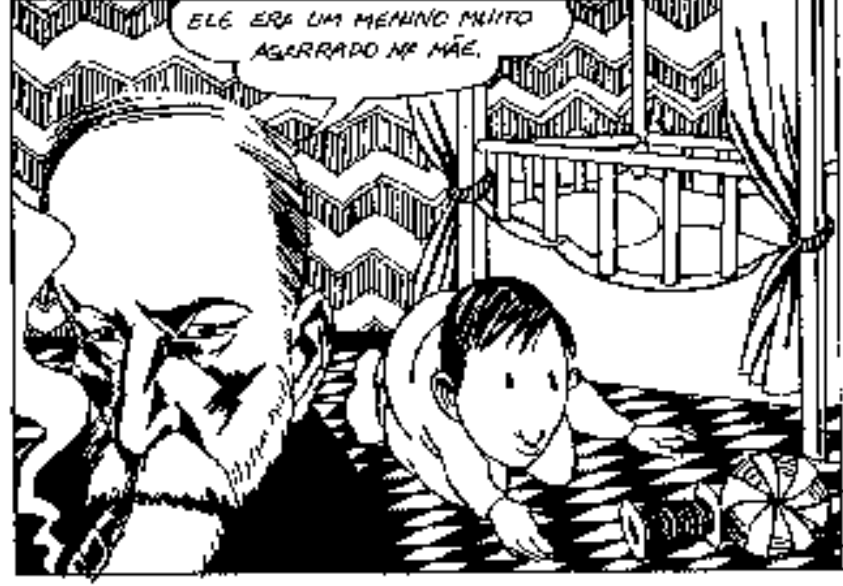

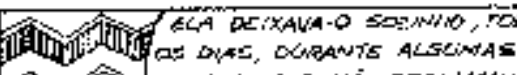

Aी [I]

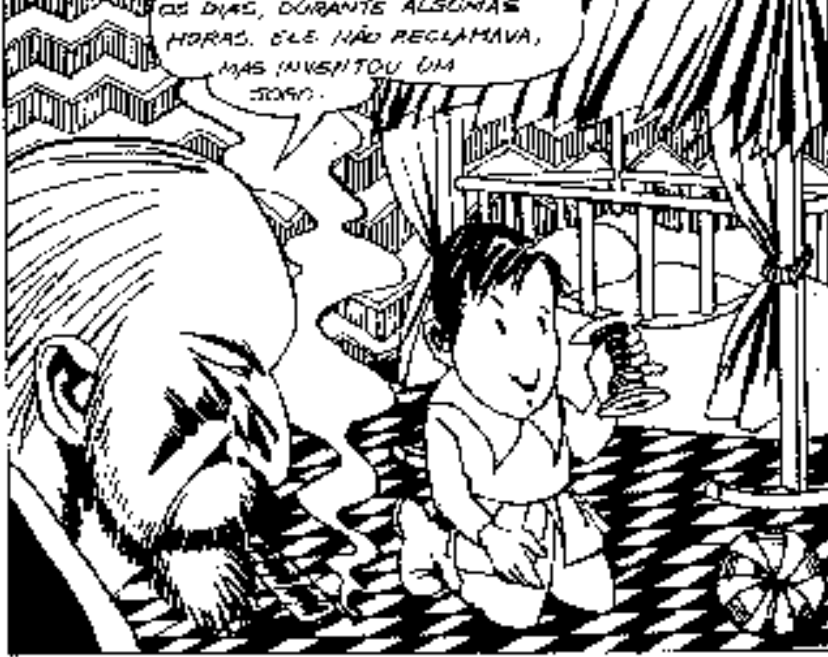

147 


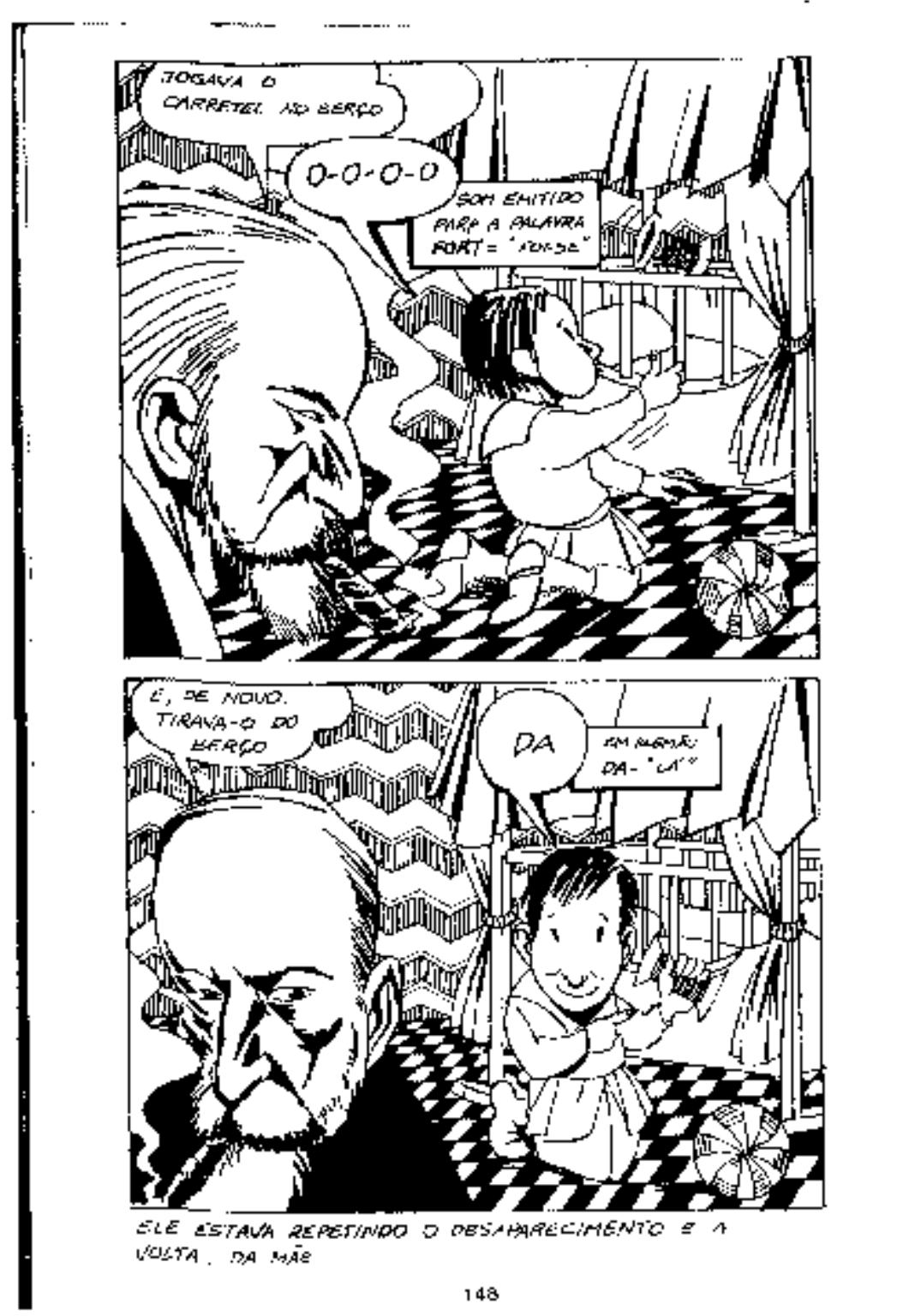


Na conclusão do Prefácio de Marcelo de Paiva Abreu para a edição brasileira do livro As Consequências Econômicas da Paz, assim, conclui o prefaciante:

Por três vezes, entre 1815 e 1945, colocou-se, de forma dominante no cenário internacional, a escolha do formato da paz na Europa. Em 1815, a restauração monárquica na França permitiu que a reconciliação européia se fizesse em torno dos objetivos da Santa Aliança e à sombra da balança de poder perseguida na $\mathrm{Pax}$ Britannica.

O mundo unipolar britânico facilitava a manutenção da paz no centro do sistema. A disputa pela hegemonia no continente, entretanto, tornou-se de administração crescentemente difícil para uma Grã-Bretanha em declínio, primeiro industrialmente, e, logo em seguida, também financeira, política e militarmente. Com o declínio da França, a Alemanha surgiu como potência hegemônica continental no Salão dos Espelhos de Versalhes em 1871.

As duas guerras mundiais podem ser vistas, na sua origem, como generalizações, através do dominó dos sistemas de alianças, de conflitos franco-alemães pela preeminência na Europa, agravados por disputas imperiais envolvendo interesses britânicos, norte-americanos, japoneses e russos ou soviéticos.

Na conferência de Versalhes, em 1919, a nascente ameaça soviética não foi suficiente para conter de forma significativa os anseios nacionais da Alemanha e da França que continuaram referidas a projetos nacionais baseados em ilusões hegemônicas. Keynes brandiu Lênin, mas em vão: a ameaça bolchevique não tornou mais razoáveis os senhores de Versalhes e, menos ainda, os seus sucessores. 
Só em 1945, a consciência da real ameaça soviética no plano político e principalmente militar, fez com que as elites européias concentrassem os seus esforços na busca de uma solução pacífica do conflito pela hegemonia européia ocidental. Ironicamente, demandas de sacrifícios políticos muito mais exigentes do que em 1919 foram atendidas em face das realidades do mundo bipolar e da dependência militar da Europa em relação aos Estados Unidos. Apurações de responsabilidades, monstruosas no caso da Alemanha hitlerista, foram quase que perfunctórias. Foram lançadas as bases da unificação econômica da Europa continental e a paz européia tem repousado firmemente desde então na parceria entre Berlim e Paris.

Com o benefício da visão retrospectiva é curioso constatar que, mesmo depois de outra guerra mundial em que os franceses sofreram diretamente de forma muito mais intensa as conseqüências de uma política expansionista da Alemanha, o compromisso político franco-alemão acabou sendo possível. Já a Grã-Bretanha continuou em dúvida quanto ao ponto de referência principal de sua política externa, ajustando-se ao colapso do Império: ou Estados Unidos, ou Europa Continental sob a hegemonia (franco)-alemã. Passados mais de oitenta anos ainda é verdade o que Keynes escreveu em 1919: “A Inglaterra (sic) ainda permanece fora da Europa. 
MAS AGORA, FAEUP PERGENTAW:

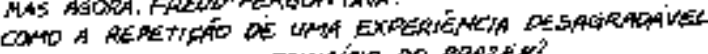

SO ENCAIXA COM O PONCINO DO PROEER?

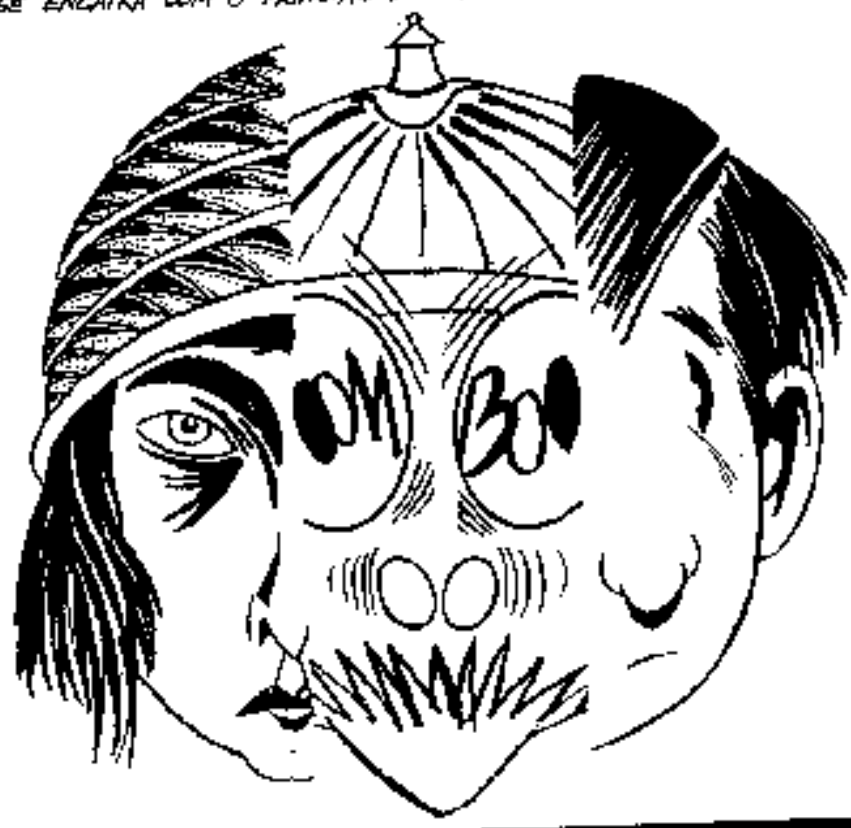

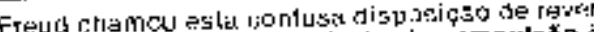

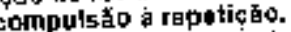

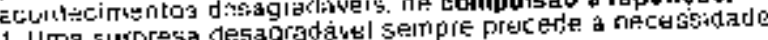

de irtsetir.

2. Normalmentia, a ansiadade é gue nos prepera diante da expeclatura de petico.

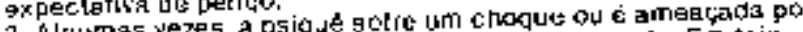

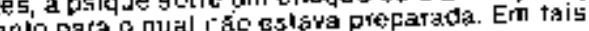

um

casos, a ensedave ó que, normalmenle nos pretege

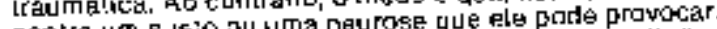

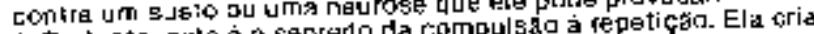
4. Partentio eate e o segredo da compula oulday palavtas. a

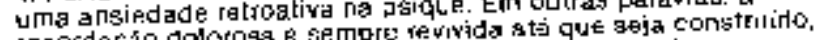
recordacho doloross e sempre revivida ste que seja con

Em sou livro Para alóm do principio do prazer '1920), Freud

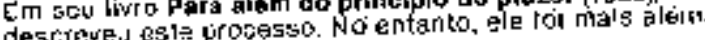




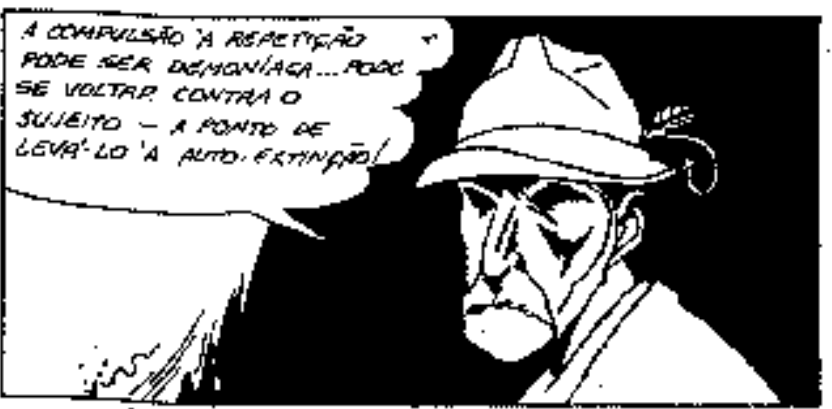

TAL EWDENCIA LEUR FAEUO A PROALR UM OUTAO TIPO DE INSTINTO - INSTINTO DE MORYEF

\section{Instinto de morte ou TANATOS (do grego, Morte)}

A LUTA DO 54LMATO, CONTEA

A COPPENTE, AN\&A WUTAP.

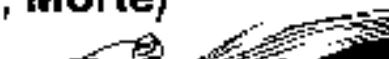

NOPRER

... Aes:30\%AR..
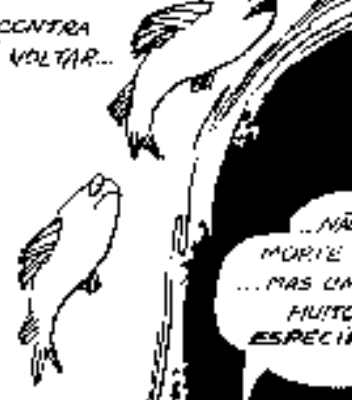

.

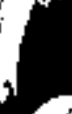

.NAD CMA MCNEIE CXNAQXER antro IsPet istof
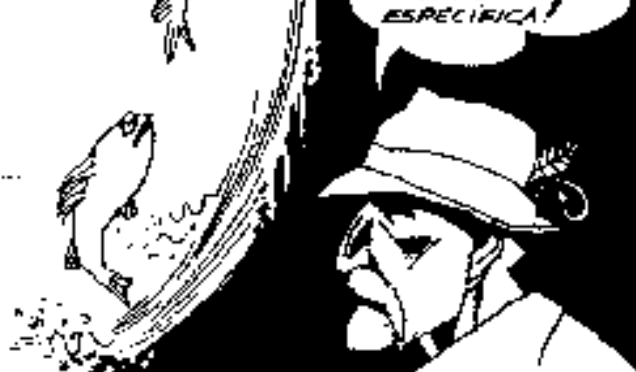

U organisino se defer de contra todas as ameaças de mort

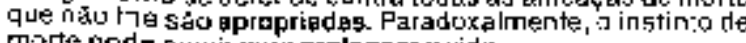
marte poda ativir pura pralongar a vida. 


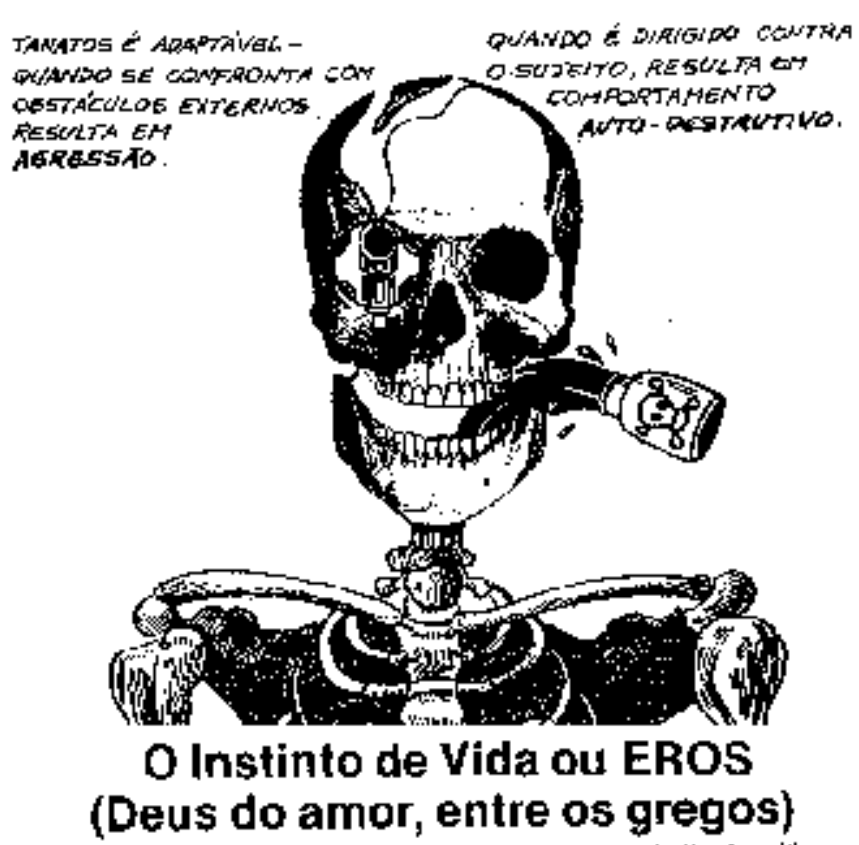

A vida de um individuo se r'ovimenta para uma murte "nalural".

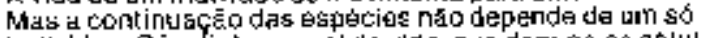

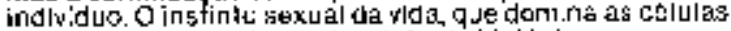

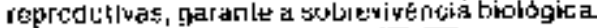

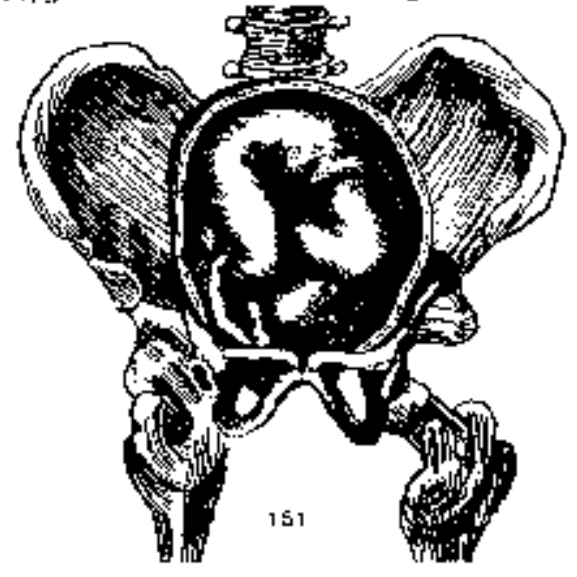


1. A Finalidade da ativldade vsiquica conslste am diminule as tensoes que foram provocadas por uma agl taçád externa u. ilusinlua.

2. O siolems nervaso de un cyanismo \& regulada peloptncipio de const incia - utha landencia para preservar a estebilidade.

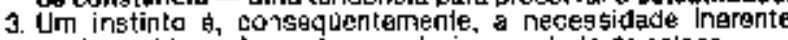
em toda yida organıca de reproduzir um estado de colsas antorior. Mas até onde val este tendancla à cornstrvidyơ

4. Cornotoda netérla vlva é formada por matérias nú vivas. n\$o orgśnićas, há, Iabvez sara alem do principı do prazer, im insilnto, cujo objerivo seja tecuperar a estado de inercia Inorgânica.

5 A compulsa a repellęa o un princlpro unstinliva regressivo. que aspira a uin usiadó de completa ausencla de energia: morte.

\section{O OBJETIVO de OUALOUER VIDA E A MORTE}

\section{OS ANOS DE SOFRIMENTO}

1920: oflina de rrevd, Soriai, s "lavorlta"; morre com 26 andos.

1623: Onetu piedilelu de Frend, or tino de Solis, marre ans $A$ anos e meic.

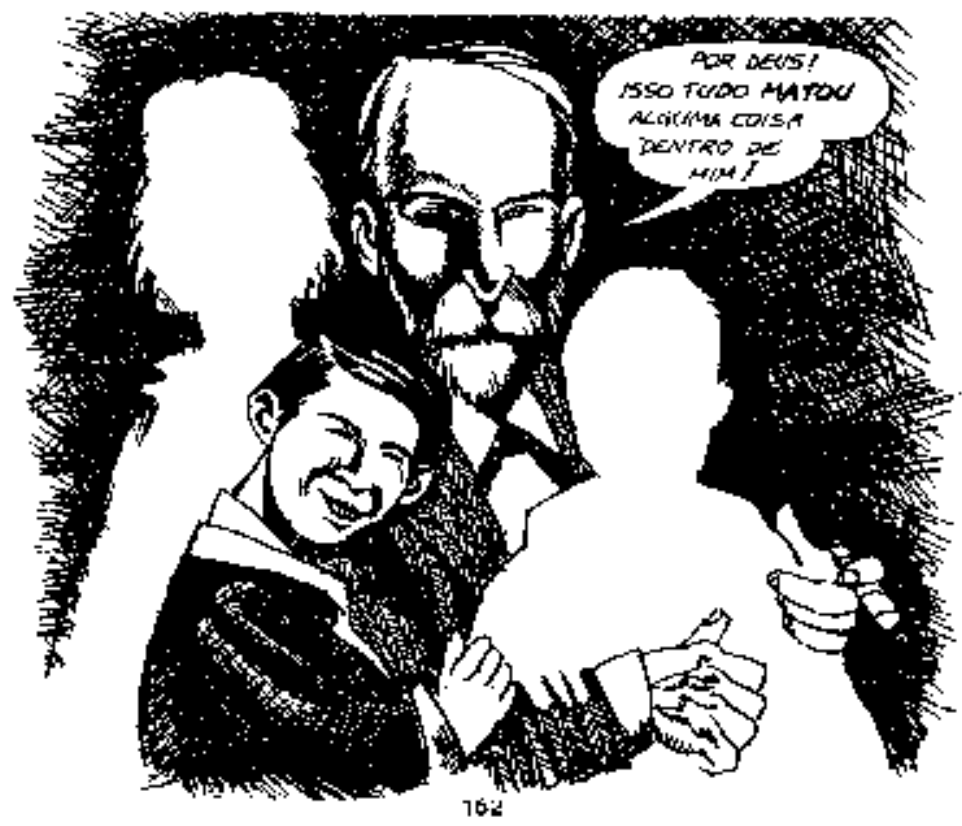


Freud destrulu a concepçác i radlclonał dạ moral e da consiolencia.

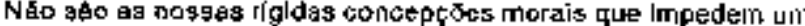
comportamento agressivo.

Ad conkrário, desenyolvemos concepcses merais, porque renunciąmos à agressán.

广o que ocorre com as religlces? Em seu livro o tuturo de uma

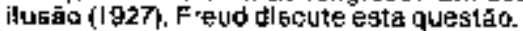

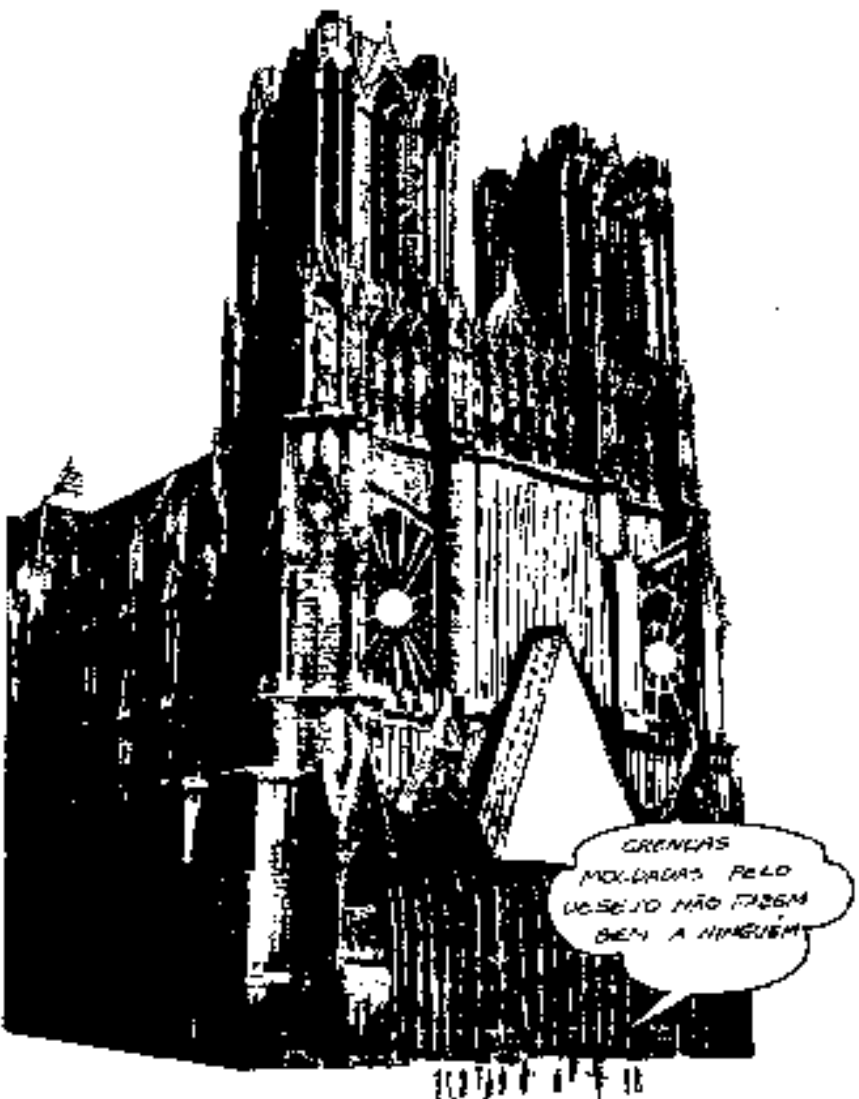

Freud era In!mifo de todas as rellgiobs. Ele nac linha esperanza na "conscitzeia" baseda em uma parte raprimida da

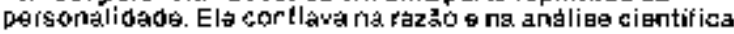
160 


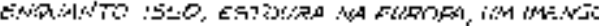

CON: $2 ; 70$ socisi.

1914 - A PRIMEIRA GUERRA

MUNDIAL - 1918

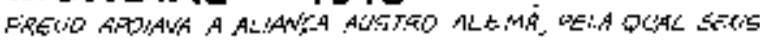
WAOS CONGATIAA

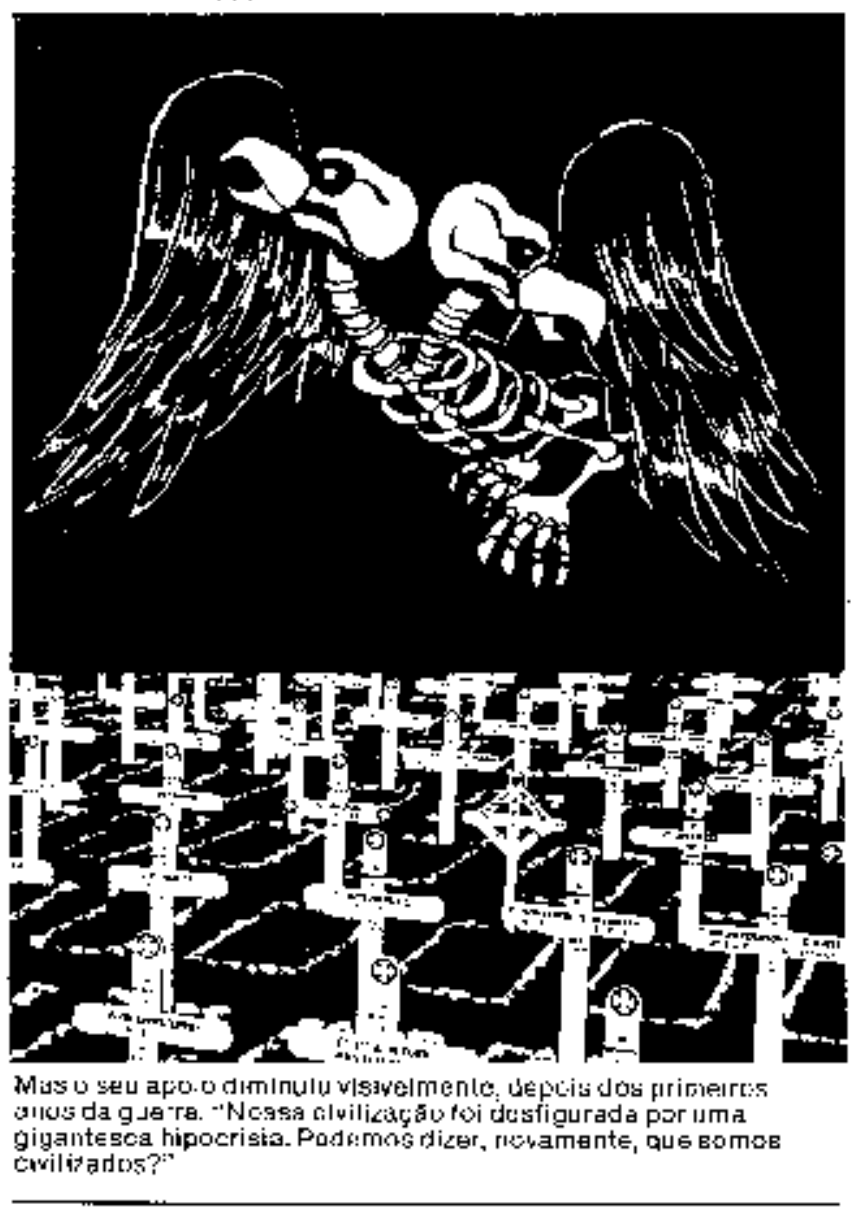

135 


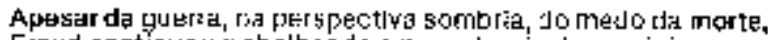
Froud cortinuou : abalhando em sua touria do narcisismo.

\section{LUTO E MELANCOLIA (1915)}

Melancolla (aqui represe ?ládé cm um quadrode Dïrer, em 1514) \&um yelho nome para a depressino psicolica.

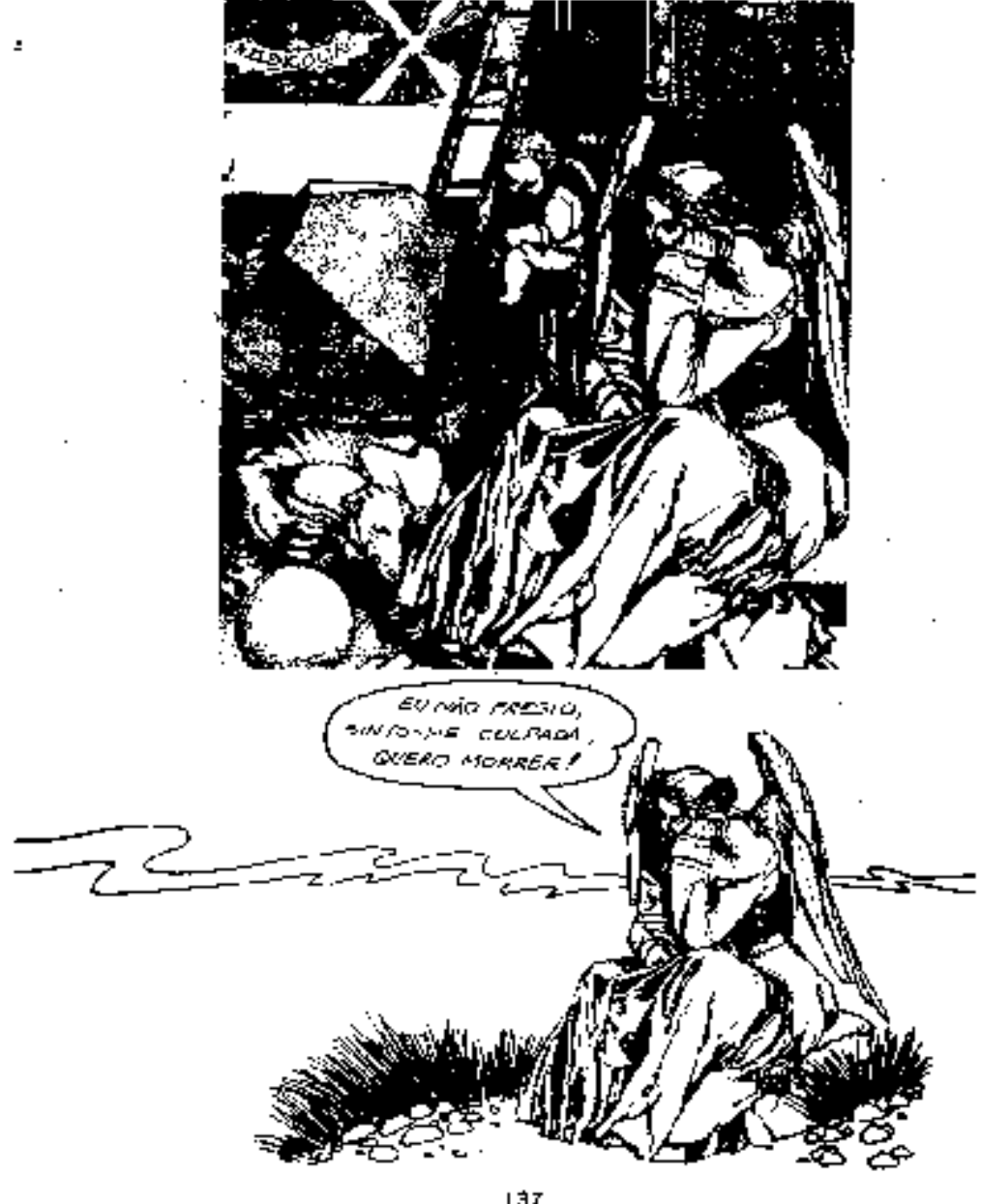

137 
Täo Ing: haja algum ll oo de relaço erótic в o prublema pode scr tratido.

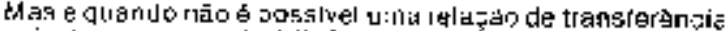

kej. de ambr, scia de 6dic? ISto pode sig jiflcer lut o packenle

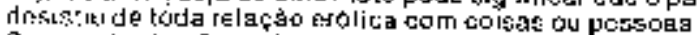

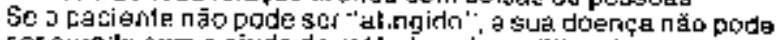

5er curada com a ajuda do mél.odo pslicanalíliço da

transly réricia.

Estês lidsus illc $\lrcorner$ rávelg ou psicolıct 5, r reud chamou de

narcisistas. 0 que ele queriat dizer $c .3 m$ isso?

\section{O MITO DE NARCISO}

toutra veltha lenda grega, gobit urt adolescerle.

maravilhosam ente belo, Que sc apaixonou por sh mesmo, pela sua propria imacem. Frıștrado, porque ná poderla se aproprlar de sl mosmo, desaparece e se iranstorma numa flor- o nomiso

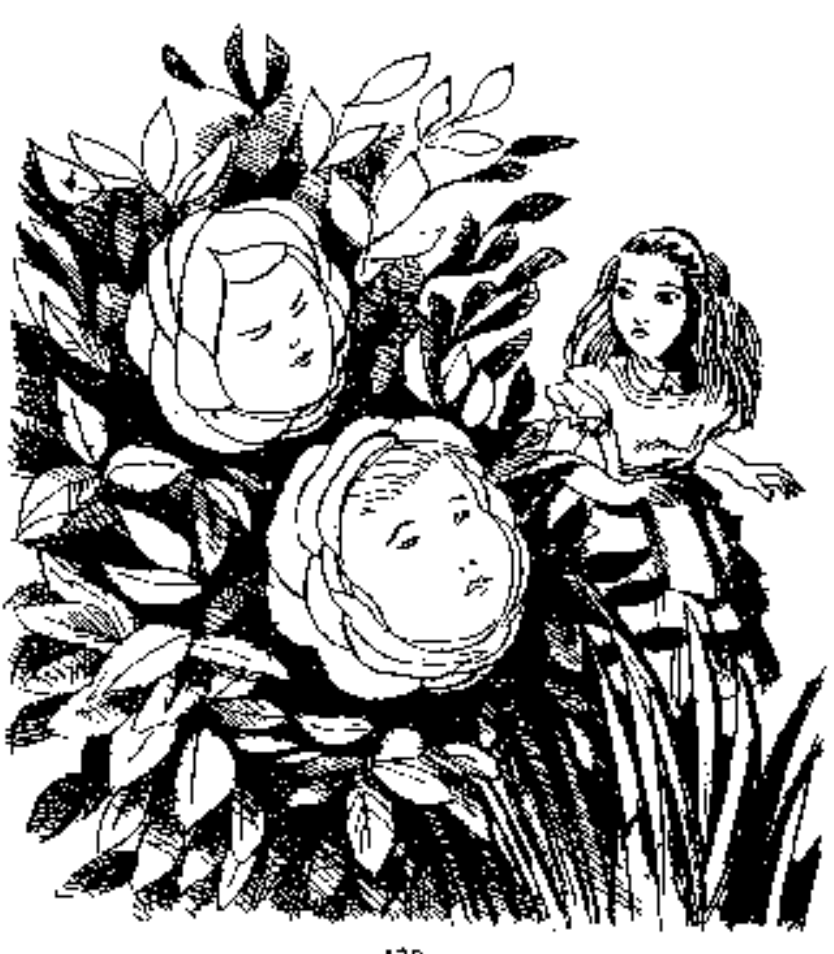

930 


\section{O NARCISISMO NORMAL}

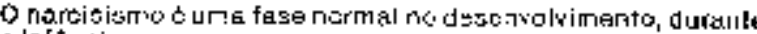
a Infäneis.

Durante a consiruçăo de scu Ego io "E.tu"!, a criança busca a sua priferia imacer. cspelha-se.

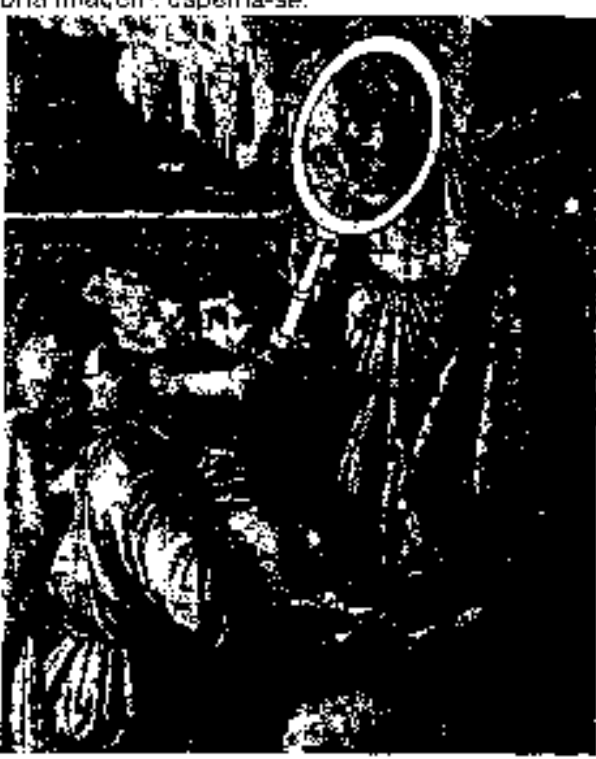

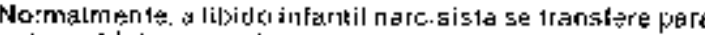

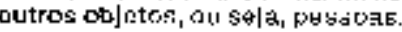

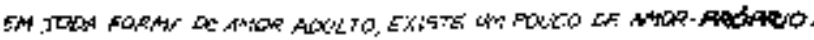

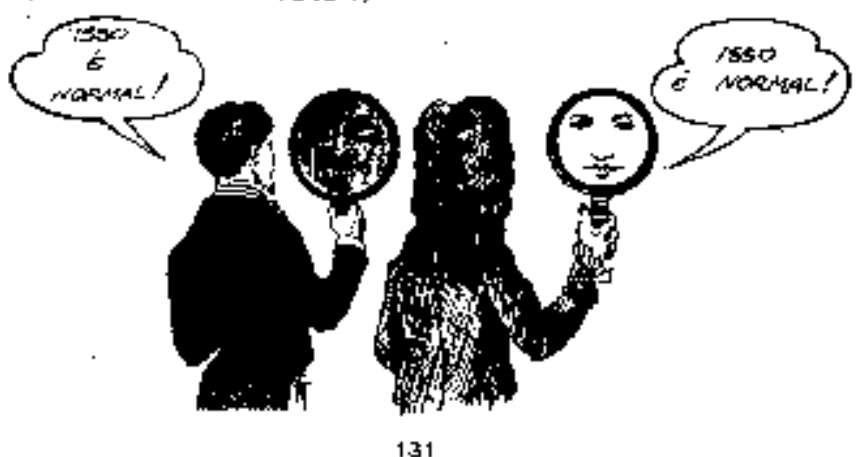




\section{E sovre o arnor ao que nos gostarlamos ut: «ur? Também ह́}

तormal?

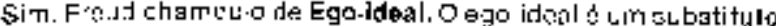

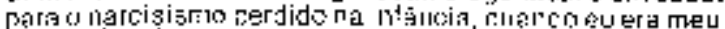
proprioideal.

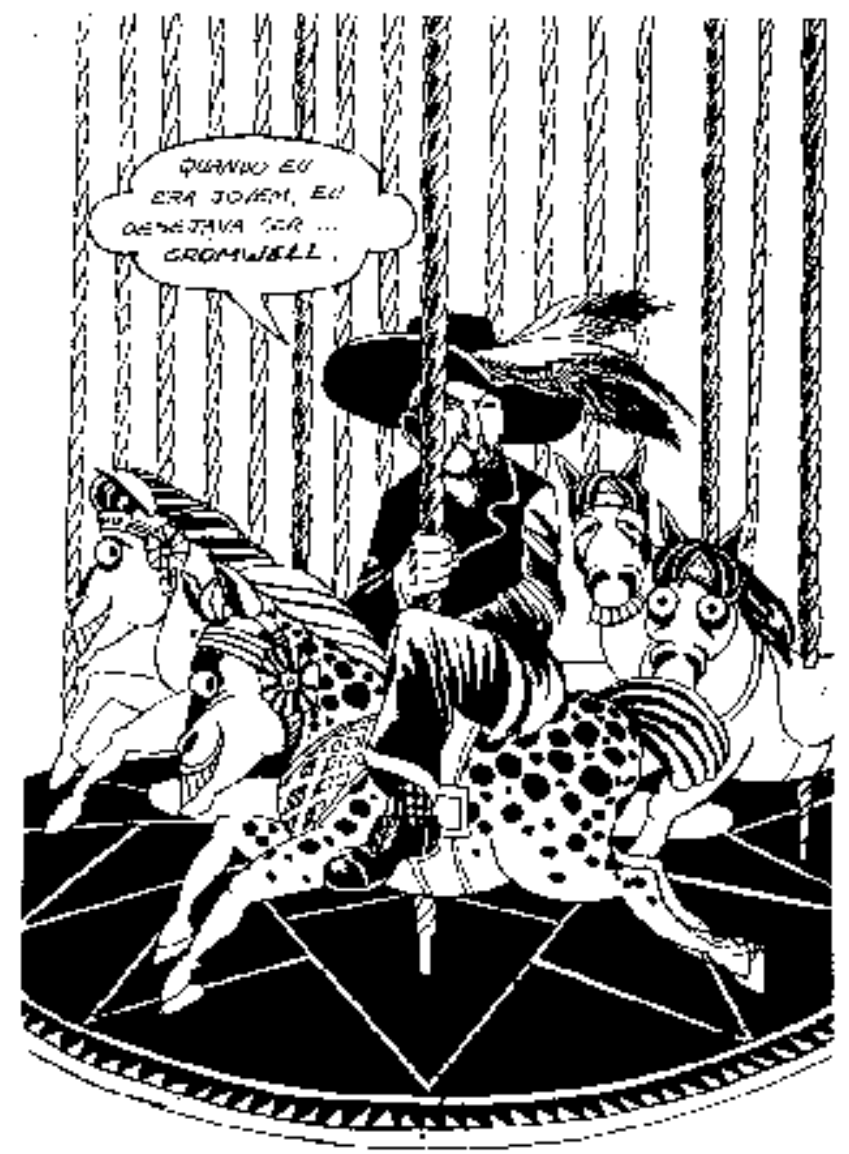

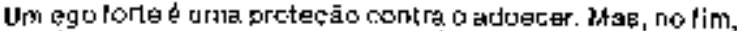
prenisamos come adoecercmos so salimos frusl adns por sajsa rk, nossa Incapacidade pria amiar. 
NARCISISMO ANORMAL

o que acunlece se a libido se recolne de riundo é dirigida da volta $9 \circ$ Ego?

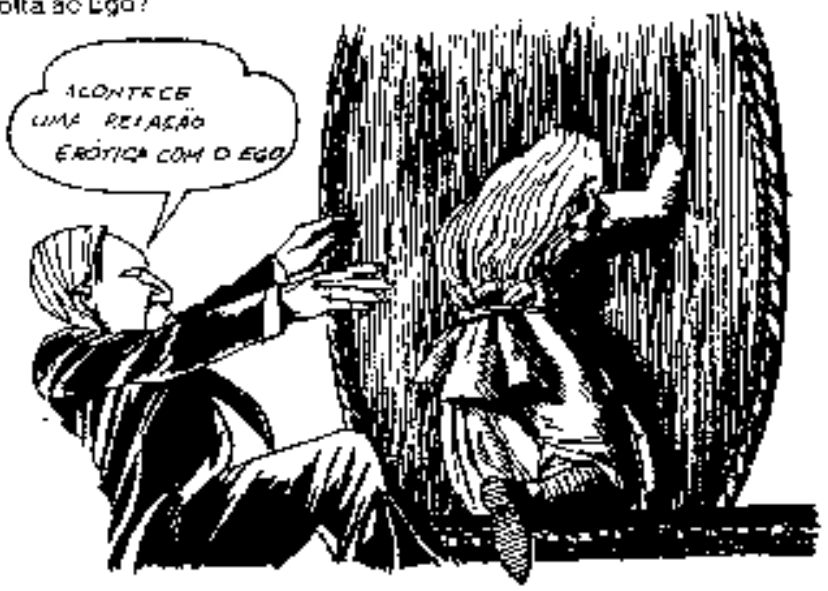

Eossa rearegabo ho marcisiano Infantil ponte lavar a sorlas

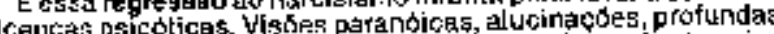
depressctes, hipotondrla, estulsoireniá, mequemanią etc. saio manifesiacoes de um estado narcisiatō psicotico.

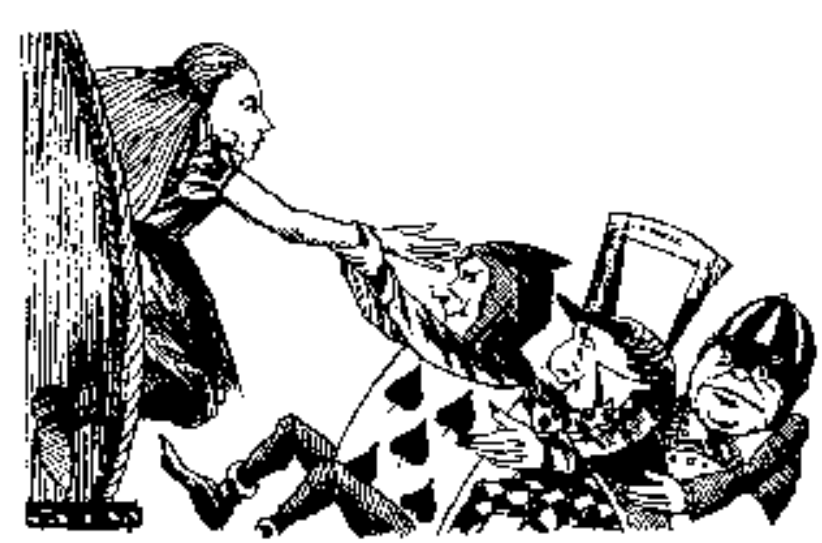

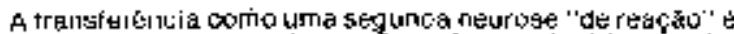
Impossivcl, porque o paclenta nag pode eser atlinçldo por relaçots ersticas axtarnags 


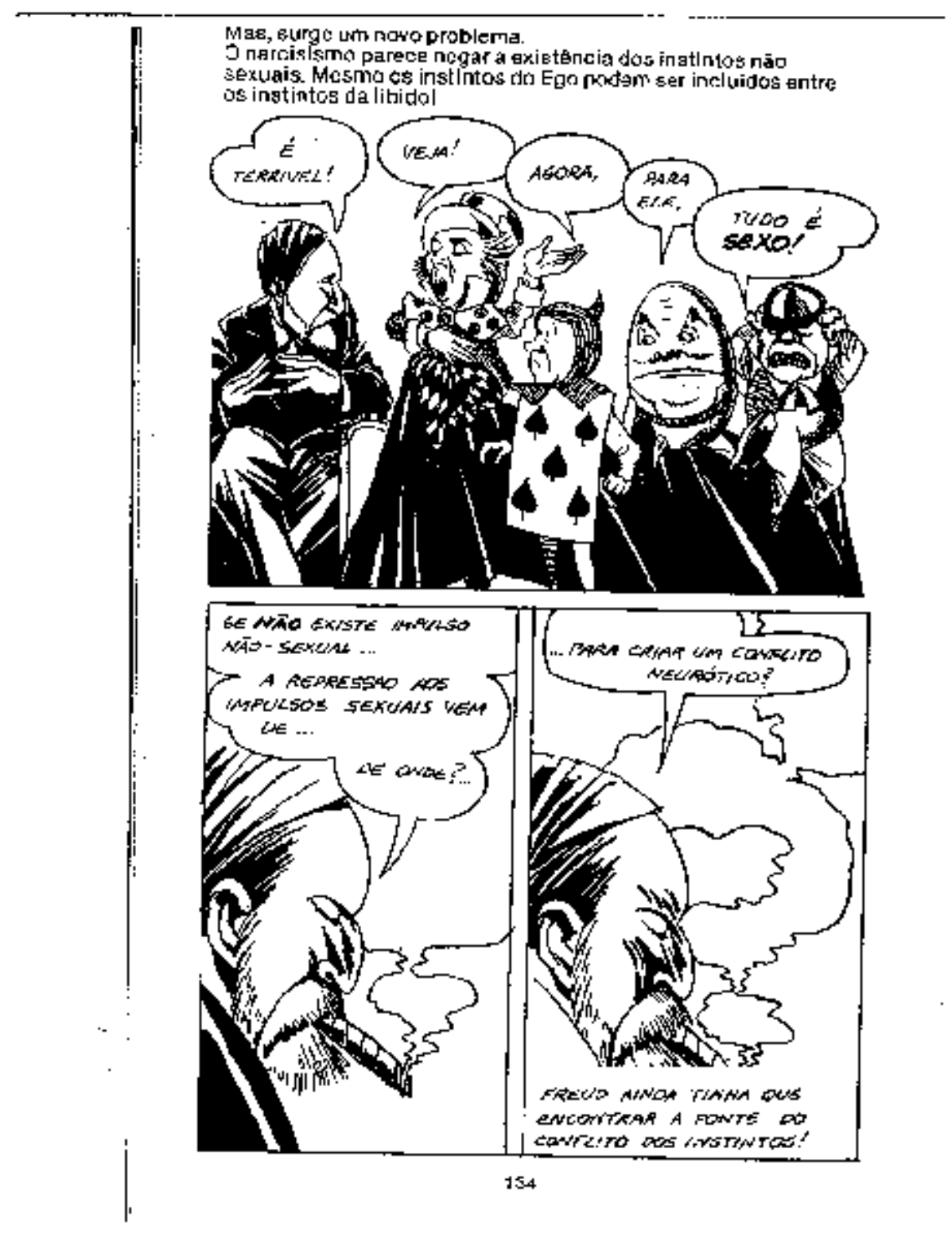




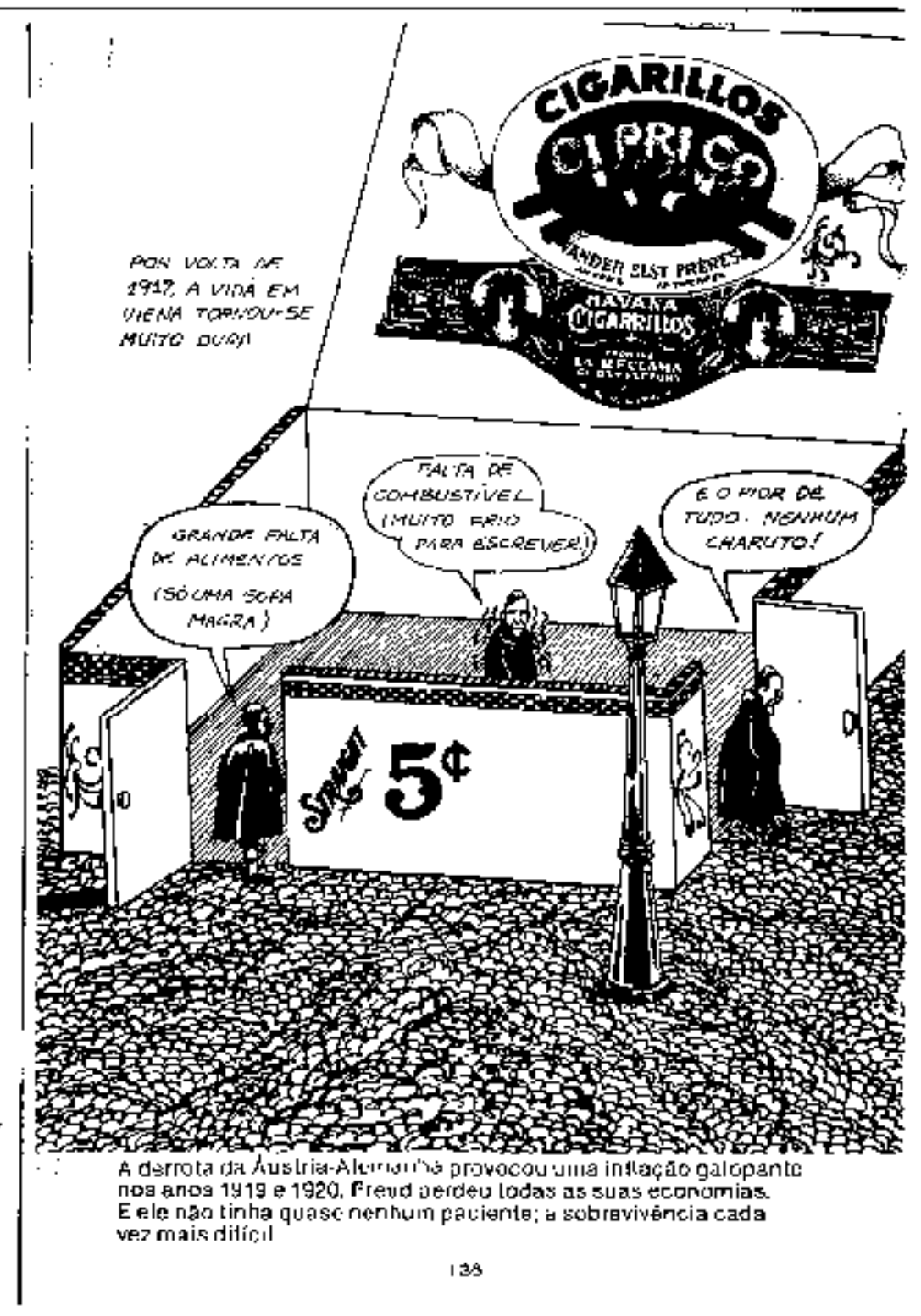


A Prime ra Guerra parecia ser a prova mals terrivel pata a lata

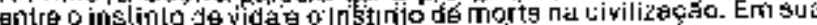
cbra, 0 mal-estar na Ediuri [193 ), Frevid queationa o valor da civilizegsa.

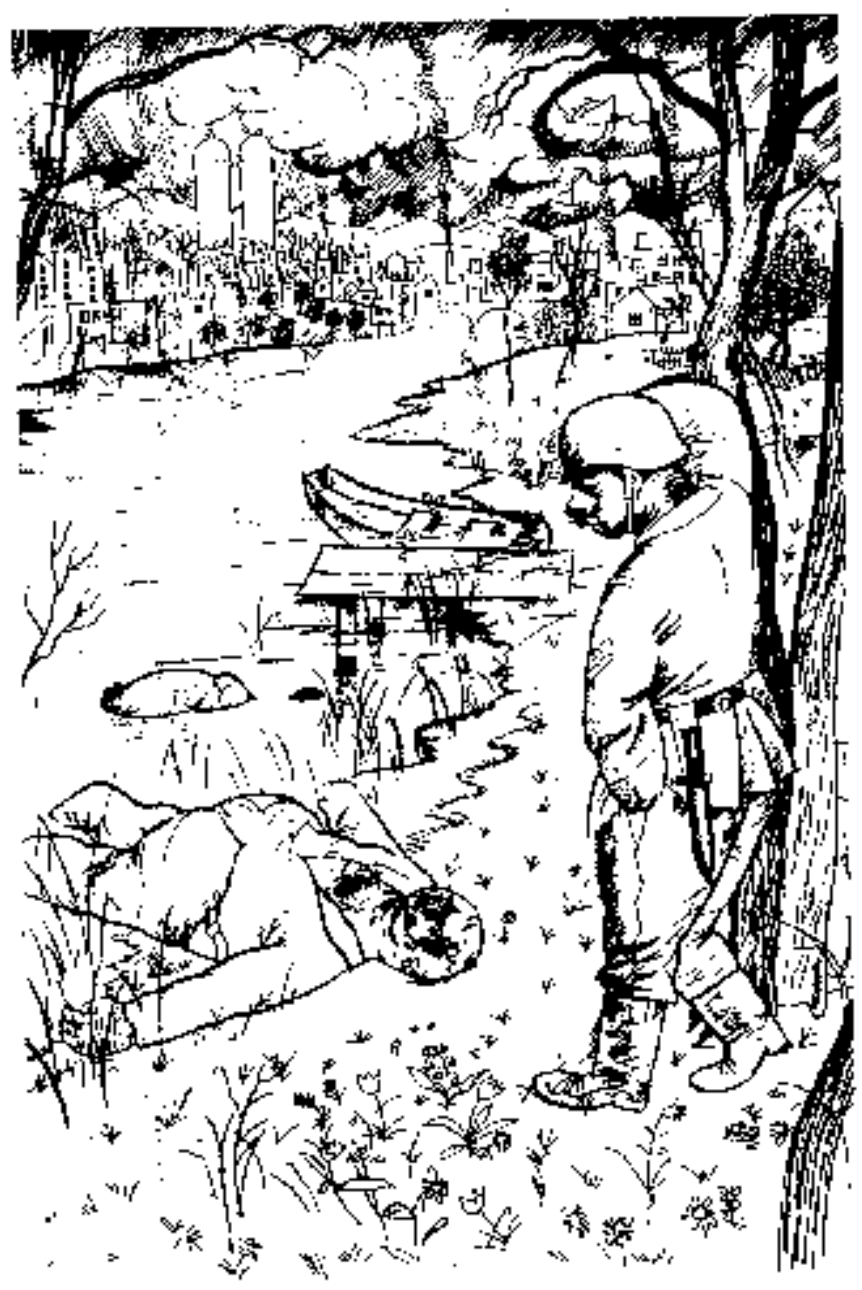

101 


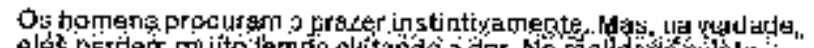
datio oxlste. melores possibjilidades ce experlmentar a frusiracinci do que 0 prazer. Por lzsio a misiorie dos homens rehunciaur ED praze. se, como compansáça, a civilizacáso proporclona-Ihes menios suf̣imento.

MAS A RQANAE QUESTHO है...

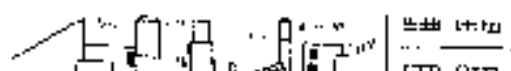

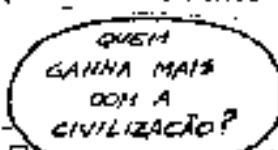

畔 整
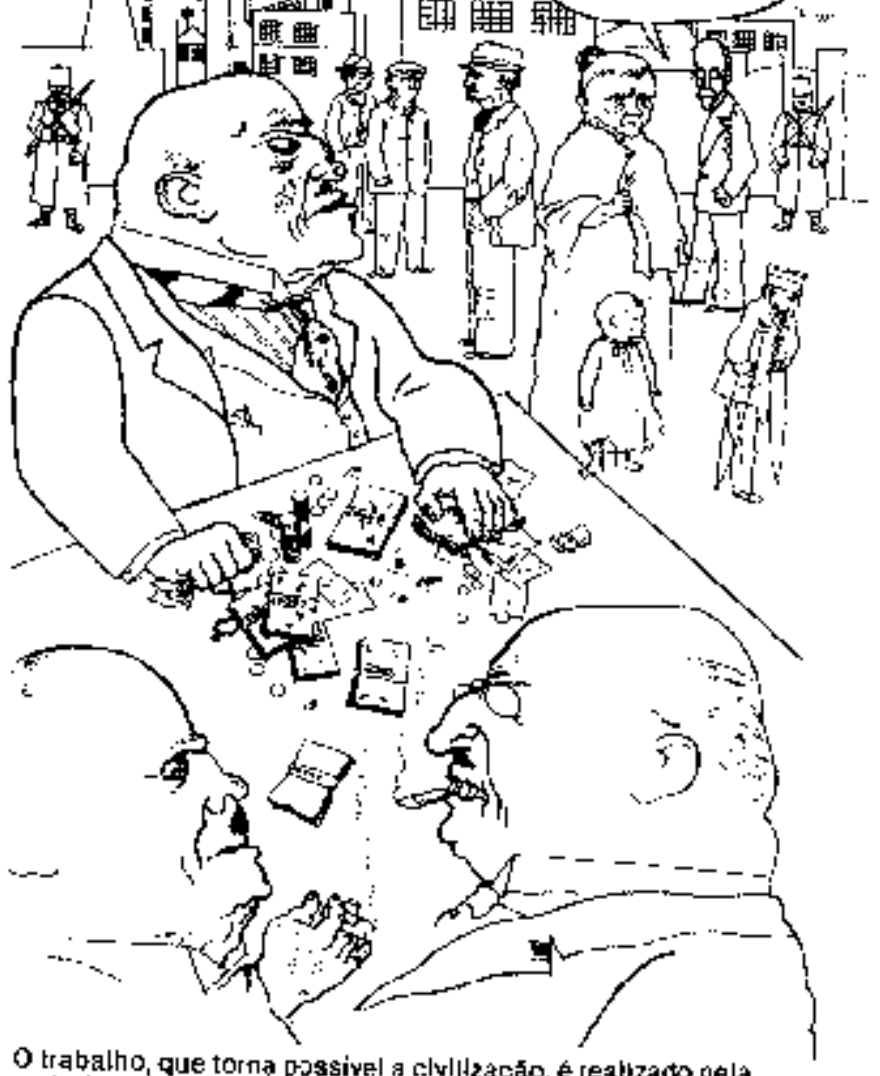

O trabalho, que torna possivel a clvl|dzaçác é reabzaob pela maioria oprimida de um povo, que tem participaçn minlma-na riqueza produzida

Nesle pon10, Freud coincid la coin Marx. 
Potsdam, 30 de julho de $1932^{225}$.

Prezado Professor Freud,

A proposta da Liga das Nações e de seu Instituto Internacional para a Cooperação Intelectual, em Paris, de que eu convidasse uma pessoa, de minha própria escolha, para um franco intercâmbio de pontos de vista sobre algum problema que eu poderia escolher, oferece-me excelente oportunidade de conferenciar com o senhor a respeito de uma questão que, da maneira como as coisas estão, parece ser o mais urgente de todos os problemas que a civilização tem de enfrentar.

Este é o problema: existe alguma forma de livrar a humanidade da ameaça de guerra?

É do conhecimento geral que, com o progresso da ciência de nossos dias, esse tema adquiriu significado de assunto de vida ou morte para a civilização, tal como a conhecemos; não obstante, apesar de todo o empenho demonstrado, todas as tentativas de solucioná-lo terminaram em lamentável fracasso.

Ademais, acredito que aqueles cuja atribuição é atacar o problema de forma profissional e prática, estão apenas adquirindo crescente consciência de sua impotência para abordá-lo, e agora possuem um vivo desejo de conhecer os pontos de

225 Ao incluir o Pacto da Sociedade das Nações, ou seja, seu tratado constitutivo, no próprio Tratado de Versalhes, que terminou, formalmente, com a Primeira Guerra Mundial, os fundadores da instituição deixaram transparecer que se tratava de uma união dos vencedores contra os vencidos, especialmente contra a Alemanha. Logo, a instituição que deveria estar acima dos Estados e servir à paz transformou-se, de fato e de direito, num instrumento de opressão constantemente criticado por Berlim, Roma, Tóquio e Moscou.

Após a concordância da derrotada Alemanha com o ingresso na Sociedade das Nações (SDN), em 1926, como consequência dos Acordos de Locarno, foi possível imaginar uma nova era nas relações europeias. Neste mesmo ano, foi fundado em Paris, no âmbito da SDN, o instituto Internacional de Cooperação Intelectual (IICI).

O objetivo do $\mathrm{IICl}$ era o de fortalecer a colaboração entre intelectuais de cultura e nacionalidades distintas, a fim de criar condições propícias ao surgimento de um novo humanismo, com o escopo de respaldar os esforços da SDN em prol da paz. É neste diálogo entre culturas que se insere a troca de correspondências, datadas de 1932, entre Einstein e Freud. in Um diálogo entre Einstein e Freud: por que a guerra? apresentação de Deisy de Freitas Lima Ventura, Ricardo Antônio Silva Seitenfus - Santa Maria: FADISMA, 2005. 
vistas de homens que, absorvidos pela busca da ciência, podem mirar os problemas do mundo sob a perspectiva que a distância permite.

Quanto a mim, o objetivo habitual de meu pensamento não me permite uma compreensão interna das obscuras regiões da vontade e do sentimento humano. Assim, na indagação ora proposta, posso fazer pouco mais do que procurar esclarecer a questão em referência e, preparando o terreno das soluções mais óbvias, possibilitar que o senhor proporcione a elucidação do problema mediante o auxílio do seu profundo conhecimento da vida instintiva do homem.

Existem determinados obstáculos psicológicos cuja existência um leigo em ciências mentais pode obscuramente entrever, cujas inter-relações e filigranas ele, contudo, é incompetente para compreender; estou convencido de que o senhor será capaz de sugerir métodos educacionais situados mais ou menos fora dos objetivos da política, os quais eliminarão esses obstáculos.

Como pessoa isenta de preconceitos nacionalistas, pessoalmente vejo uma forma simples de abordar o aspecto superficial (isto é, administrativo) do problema: a instituição, por meio de acordo internacional, de um organismo legislativo e judiciário para arbitrar todo conflito que surja entre nações. Cada nação submeter-se-ia à obediência às ordens emanadas desse organismo legislativo, a recorrer às suas decisões em todos os litígios, a aceitar irrestritamente suas decisões e a pôr em prática todas as medidas que o tribunal considerasse necessárias para a execução de seus decretos.

Já de início, todavia, defronto-me com uma dificuldade: um tribunal é uma instituição humana que, em relação ao poder de que dispõe, é inadequada para fazer cumprir seus veredictos, está muito sujeito a ver suas decisões anuladas por pressões extrajudiciais. Este é um fato com que temos de contar; a lei e o poder inevitavelmente andam de mãos dadas, e as decisões jurídicas se aproximam mais da justiça ideal exigida pela comunidade (em cujo nome e em cujos interesses esses veredictos são pronunciados), na medida em que a comunidade tem efetivamente o poder de impor o respeito ao seu ideal jurídico. 
Atualmente, porém, estamos distantes de possuir qualquer organização supranacional competente para emitir julgamentos de autoridade incontestável e garantir absoluto acatamento à execução de seus veredictos. Assim, sou levado ao meu primeiro princípio; a busca da segurança internacional envolve a renúncia incondicional, por todas as nações, em determinada medida, à sua liberdade de ação, ou seja, à sua soberania, e é absolutamente evidente que nenhum outro caminho pode conduzir a essa segurança.

O insucesso, malgrado sua evidente sinceridade, de todos os esforços, durante a última década, no sentido de alcançar essa meta, não deixa lugar à dúvida de que estão em jogo fatores psicológicos de peso que paralisam tais esforços.

Alguns desses fatores são mais fáceis de detectar. $\mathbf{O}$ intenso desejo de poder, que caracteriza a classe governante em cada nação, é hostil a qualquer limitação de sua soberania nacional. Essa fome de poder político está acostumada a medrar, graças às atividades de um outro grupo cujas aspirações são de caráter econômico, puramente mercenário. Refiro-me especialmente a esse grupo reduzido, porém decidido, existente em cada nação, composto de indivíduos que, indiferentes às condições e aos controles sociais, consideram a guerra, a fabricação e venda de armas simplesmente como uma oportunidade de expandir seus interesses pessoais e ampliar a sua autoridade pessoal. O reconhecimento desse fato, no entanto, é simplesmente o primeiro passo para uma avaliação da situação atual.

Logo surge outra questão: como é possível a essa pequena súcia dobrar a vontade da maioria, que se resigna a perder e a sofrer com uma situação de guerra, a serviço da ambição de poucos? (Ao falar em maioria, não excluo os soldados, de todas as graduações, que escolheram a guerra como profissão, na crença de que estejam servindo à defesa dos mais altos interesses de sua raça e de que o ataque seja, muitas vezes, o melhor meio de defesa).

Parece que uma resposta óbvia a essa pergunta seria que a minoria, a classe dominante atual, possui as escolas, a imprensa e, geralmente,também a Igreja, sob seu poderio. Isto possibilita organizar e dominar as emoções das massas e tornálas instrumento desta minoria. Ainda assim, nem sequer essa resposta proporciona uma 
solução completa. Daí surge uma nova questão: como esses mecanismos conseguem tão bem despertar nos homens um entusiasmo extremado, a ponto de estes sacrificarem suas vidas?

Pode haver apenas uma resposta. É porque o homem encerra dentro de si um desejo de ódio e de destruição.

Em tempos normais, essa paixão existe em estado latente, emerge apenas em circunstâncias anormais: é, contudo, relativamente fácil despertá-la e elevá-la à potência de psicose coletiva. Talvez aí esteja o ponto crucial de todo o complexo de fatores que estamos considerando, um enigma que só um especialista na ciência dos instintos humanos pode resolver.

Com isso, chegamos à nossa última questão.

É possível controlar a evolução da mente do homem, de modo a torná-lo à prova das psicoses do ódio e da destrutividade?

Aqui não me estou referindo tão somente às chamadas massas incultas. A experiência prova que é, antes de todas, a chamada Intelligentzia a mais inclinada a ceder a essas desastrosas sugestões coletivas, de vez que o intelectual não tem contato direto com o lado rude da vida, mas a encontra em sua forma sintética mais fácil na página impressa.

Para concluir: até aqui somente falei das guerras entre nações, aquelas que se conhecem como conflitos internacionais. Estou, porém, bem consciente de que o instinto agressivo opera sob outras formas e em outras circunstâncias. (Penso nas guerras civis, por exemplo, devidas à intolerância religiosa, em tempos precedentes, hoje em dia, contudo, devidas a fatores sociais; ademais, também nas perseguições a minorias raciais)

Foi deliberada a minha insistência naquilo que é a mais típica, mais cruel e extravagante forma de conflito entre os homens, pois aqui temos a melhor ocasião de descobrir maneiras e meios de tornar impossíveis qualquer conflito armado. 
Sei que nos escritos do senhor podemos encontrar respostas, explícitas ou implícitas, a todos os aspectos desse problema urgente e obsessivo. Mas seria da maior utilidade para nós todos que o senhor apresentasse o problema da paz mundial sob o enfoque das suas mais recentes descobertas, pois uma tal apresentação bem poderia demarcar o caminho para novos e frutíferos métodos de ação.

Muito cordialmente,

Albert Einstein ${ }^{226}$

${ }^{226}$ Com o acesso de Hitler ao poder, Albert Einstein renunciou à cidadania alemã e mudou-se para os Estados Unidos. Alí, passou seus últimos vinte e cinco anos de vida, trabalhando no Instituto de Estudos Superiores de Princeton, cidade em que morreu em 18 de abril de 1955.

Assim que houve as explosões de Hiroshima e Nagasaki, Einstein uniu-se aos cientistas que buscavam uma maneira de impedir o uso futuro da bomba e propôs a formação de um governo mundial com base no embrião constituído pelas Nações Unidas. 
Freud continuava se pergintando: como os hamens se

identiflçam com um grupo ou uma sociedade?

a apropriaḉa libidinosa de um ob|eto pode tambarm se dar em

escala megaiva.

Os individuos coldceam um a o mestomo ob]elo no lugardo

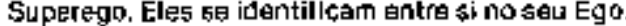

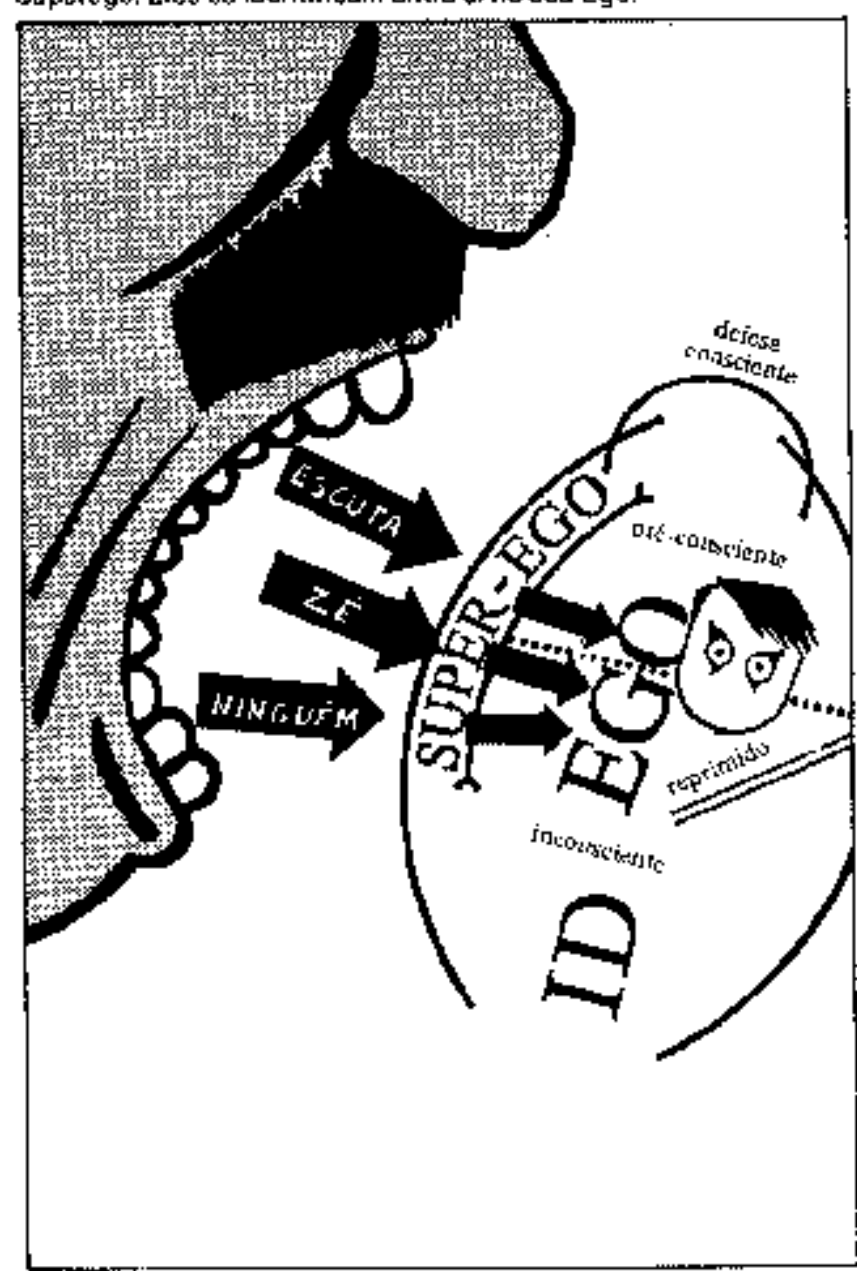

$1+5$ 
Viena, setembro de 1932.

Prezado Professor Einstein,

Quando soube que o senhor pretendia convidar-me para um intercâmbio de pontos de vista sobre um assunto que lhe interessava e que parecia merecer o interesse de outros além do senhor, aceitei prontamente. Esperava que o senhor escolhesse um problema situado nas fronteiras daquilo que é atualmente cognoscível, um problema em relação ao qual cada um de nós, físico e psicólogo, pudesse ter o seu ângulo de abordagem especial, e no qual pudéssemos nos encontrar, sobre o mesmo terreno, embora partindo de direções diferentes.

O senhor apanhou-me de surpresa, no entanto, ao perguntar o que pode ser feito para proteger a humanidade da maldição da guerra.

Inicialmente me assustei com o pensamento de minha - quase escrevi de nossa - incapacidade de lidar com o que parecia ser um problema prático, um assunto para Estadistas. Depois, no entanto, percebi que o senhor havia proposto a questão, não na condição de cientista da natureza e físico, mas como filantropo: o senhor estava seguindo a sugestão da Liga das Nações, assim como Fridtjof Nansen, o explorador polar, assumiu a tarefa de auxiliar as vítimas famintas e sem teto da guerra mundial.

Além do mais, considerei que não me pediam para propor medidas práticas, mas sim apenas que eu delimitasse o problema para evitar a guerra tal como ela se configura aos olhos de um cientista da psicologia.

Também nesse ponto, o senhor disse quase tudo o que há a dizer sobre o assunto. Embora o senhor se tenha antecipado a mim, ficarei satisfeito em seguir no seu rastro e me contentarei com confirmar tudo o que o senhor disse, ampliando-o com o melhor do meu conhecimento ou das minhas conjeturas.

O senhor começou com a relação entre o direito e o poder.

Não se pode duvidar de que seja este o ponto de partida correto de nossa investigação. Mas, permita-me substituir a palavra "poder" pela palavra, mais dura e crua, 'força'?

Atualmente, direito e força se nos afiguram como antíteses. 
No entanto, é fácil mostrar que um se desenvolveu da outra e, se nos reportarmos às origens primeiras e examinarmos como essas coisas se passaram, resolve-se o problema facilmente.

Perdoe-me se, nessas considerações que se seguem, eu trilhar chão familiar e comumente aceito, como se isto fosse novidade. $O$ fio de minhas argumentações o exige. É, pois, um princípio geral que os conflitos de interesses entre os homens são resolvidos pelo uso da força. É isto o que se passa em todo o reino animal, do qual o homem não tem motivo por que se excluir. No caso do homem, sem dúvida, ocorrem também conflitos de opinião que podem chegar a atingir a mais raras nuanças da abstração e que parecem exigir alguma outra técnica para sua solução.

Esta é, contudo, uma complicação a mais.

No início, numa pequena horda humana, era a superioridade da força muscular que decidia quem tinha a posse das coisas ou quem fazia prevalecer sua vontade. A força muscular logo foi suplementada e substituída pelo uso de instrumentos: o vencedor era aquele que tinha as melhores armas ou aquele que tinha a maior habilidade no seu manejo.

A partir do momento em que as armas foram introduzidas, a superioridade intelectual já começou a substituir a força muscular bruta; mas o objetivo final da luta permanecia o mesmo: uma ou outra facção tinha de ser compelida a abandonar suas pretensões ou suas objeções, por causa do dano que lhe havia sido infligido pelo desmantelamento de sua força.

Conseguia-se esse objetivo de modo mais completo, se a força do vencedor eliminasse para sempre o adversário, ou seja, se o matasse. Isto tinha duas vantagens: o vencido não podia restabelecer sua oposição e o seu destino dissuadiria outros de seguirem seu exemplo.

Ademais disso, matar um inimigo satisfazia uma inclinação do instinto, que mencionarei posteriormente.

À intenção de matar opor-se-ia a reflexão de que o inimigo podia ser utilizado na realização de serviços úteis, se fosse deixado vivo e num estado de intimidação. Nesse caso, a violência do vencedor contentava-se com subjugar, em vez de matar, o vencido. Foi este o início da idéia de poupar a vida de um inimigo, mas a partir daí o vencedor teve de contar com a oculta sede de vingança do adversário vencido e sacrificou uma parte de sua própria segurança. 
Esta foi, por conseguinte, a situação inicial dos fatos: domina o maior poderio, a força bruta ou a força fundamentada intelectualmente. Como sabemos, esse regime foi modificado no transcurso da evolução. Havia um caminho que se estendia da violência ao direito ou à lei.

Que caminho era este? Penso ter sido apenas um: o caminho que levava ao reconhecimento do fato de que à força superior de um único indivíduo, podia-se contrapor a união de diversos indivíduos fracos: a união faz a força. A violência podia ser derrotada pela união, e o poder daqueles que se uniam representa, agora, a lei, em contraposição à força de um indivíduo só. Vemos, assim, que a lei é a força de uma comunidade.

Todavia, ela é ainda violência, pronta a se voltar contra qualquer indivíduo que se lhe oponha. Ela funciona pelos mesmos métodos e persegue os mesmos objetivos. A única diferença real reside no fato de que aquilo que prevalece não é mais a violência de um indivíduo, mas a força da comunidade. A fim de que a transição da violência a esse novo direito ou justiça pudesse ser efetuada, contudo, uma condição psicológica teve de ser preenchida. A união da maioria devia ser estável e duradoura.

Se apenas fosse posta em prática com o propósito de combater um indivíduo isolado e dominante, e fosse dissolvida depois da derrota deste, nada se teria realizado. A pessoa, a seguir, que se julgasse superior em força, haveria de mais uma vez tentar estabelecer o domínio por meio da violência, e o jogo se repetiria ad infinitum. A comunidade deve manter-se permanentemente, deve organizar-se, deve estabelecer regulamentos para antecipar-se ao risco de rebelião e deve instituir autoridades para fazer com que esses regulamentos, as leis, sejam respeitados, e para superintender a execução dos atos legais de força.

O reconhecimento de uma entidade de interesses como estes levou ao surgimento de vínculos emocionais entre os membros de um grupo de pessoas unidas, sentimentos comuns, que são a verdadeira fonte de sua força. Acredito que, com isso, já tenhamos todos os elementos essenciais: a força suplantada pela transferência do poder a uma unidade maior, que se mantém unida por laços emocionais entre os seus membros. O que resta dizer não é senão uma ampliação e uma repetição desse fato.

A situação é simples enquanto a comunidade consiste em apenas poucos indivíduos igualmente fortes. As leis de uma tal associação irão determinar o grau em que, 
se a segurança da vida comunal deve ser garantida, cada indivíduo deve abrir mão de sua liberdade pessoal de utilizar a sua força para fins violentos.

Um estado de equilíbrio dessa espécie, porém, só é concebível teoricamente. Na realidade, a situação complica-se pelo fato de que, desde os seus primórdios, a comunidade abrange elementos de força desigual : homens e mulheres, pais e filhos, e logo, como conseqüência da guerra e da conquista, também passa a incluir vencedores e vencidos, que se transformam em senhores e escravos.

A justiça da comunidade, então, passa a exprimir graus desiguais de poder nela vigentes. As leis são feitas por e para os membros governantes e deixa pouco espaço para os direitos daqueles que se encontram em estado de sujeição. Dessa época em diante, existem na comunidade dois fatores em atividade que são fonte de inquietação relativamente a assuntos da lei, mas que tendem, ao mesmo tempo, a um maior crescimento da lei.

Primeiramente, são feitas, por certos detentores do poder, tentativas, no sentido de se colocarem acima das proibições que se aplicam a todos, isto é, procuram escapar do domínio pela lei para o domínio pela violência. Em segundo lugar, os membros oprimidos do grupo fazem constantes esforços para obter mais poder e ver reconhecidas na lei algumas modificações efetuadas nesse sentido, isto é, fazem pressão para passar da justiça desigual para a justiça igual para todos. Essa segunda tendência torna-se especialmente importante se uma mudança real de poder ocorre dentro da comunidade, como pode ocorrer em conseqüência de diversos fatores históricos. Nesse caso, o direito pode gradualmente adaptar-se à nova distribuição do poder; ou, como sucede com maior freqüência, a classe dominante se recusa a admitir a mudança e a rebelião e a guerra civil seguem-se, com uma suspensão temporária da lei e com novas tentativas de solução mediante a força, terminando pelo estabelecimento de um novo sistema de leis.

Ainda há uma terceira fonte da qual podem surgir modificações da lei, e que, invariavelmente, se exprime por meios pacíficos: consiste na transformação cultural dos membros da comunidade. Isto, porém, faz parte propriamente de outra correlação e deve ser considerado posteriormente.

Vemos, pois, que a solução violenta de conflitos de interesses não é evitada sequer dentro de uma comunidade. As necessidades cotidianas e os interesses comuns, inevitáveis ali onde pessoas vivem juntas num lugar, tendem, contudo, a 
proporcionar a essas lutas uma conclusão rápida, e, sob tais condições, existe uma crescente probabilidade de se encontrar uma solução pacífica.

Outrossim, um rápido olhar pela história da raça humana revela uma série infindável de conflitos entre uma comunidade e outra, ou diversas outras, entre unidades maiores e menores entre cidades, províncias, raças, nações, impérios, que quase sempre se formaram pela força das armas. Guerras dessa espécie terminam ou pelo saque ou pelo completo aniquilamento e conquista de uma das partes.

É impossível estabelecer qualquer julgamento geral das guerras de conquista. Algumas, como as empreendidas pelos mongóis e pelos turcos, não trouxeram senão malefícios. Outras, pelo contrário, contribuíram para a transformação da violência em lei, ao estabelecerem unidades maiores, dentre as quais o uso da força se tornou impossível e nas quais um novo sistema de leis solucionou os conflitos. Desse modo, as conquistas dos romanos deram aos países próximos ao Mediterrâneo a inestimável pax romana, e a ambição dos reis franceses de ampliar os seus domínios criou uma França pacificamente unida e florescente.

Por paradoxal que possa parecer, deve-se admitir que a guerra poderia ser um meio nada inadequado de estabelecer o reino ansiosamente desejado de paz 'eterna', pois está em condições de criar as grandes unidades dentro das quais um poderoso governo central torna impossíveis outras guerras. Contudo, ela falha quanto a esse propósito, pois os resultados da conquista são geralmente de curta duração: as unidades recentemente criadas esfacelam-se novamente, no mais das vezes, devido a uma falta de coesão entre as partes que foram unidas pela força. Ademais, até hoje as unificações criadas pela conquista, embora de extensão considerável, foram apenas parciais, e os conflitos entre elas ensejaram, mais do que nunca, soluções violentas. $\mathrm{O}$ resultado de todos esses esforços bélicos levou a humanidade trocar as numerosas e realmente infindáveis guerras menores por guerras menos frequentes, contudo muito mais destrutivas.

Se nos voltarmos para os nossos próprios tempos, chegamos à mesma conclusão a que o senhor chegou por um caminho mais curto. As guerras somente serão evitadas com certeza, se a humanidade se unir para estabelecer uma autoridade central a que será conferido o direito de arbitrar todos os conflitos de interesses. Nisto estão envolvidos claramente dois requisitos distintos: criar uma instância suprema e dotá-la do necessário poder. Uma sem a outra seria inútil. A Liga das Nações é destinada a ser uma instância dessa espécie, mas a segunda condição não foi preenchida: a 
Liga das Nações não possui poder próprio, e só pode adquiri-lo se os membros da nova união, os diferentes Estados, se dispuserem a cedê-lo. E, no momento, parecem escassas as perspectivas nesse sentido.

A instituição da Liga das Nações seria totalmente ininteligível se fosse ignorado o fato de que houve uma tentativa corajosa, como raramente (talvez jamais em tal escala) se fez antes. Ela é uma tentativa de fundamentar a autoridade sobre um apelo a determinadas atitudes idealistas da mente (isto é, o poder de influir peremptoriamente) que, de outro modo, desprende do poderio. Já vimos que uma comunidade se mantém unida por duas coisas: o império da violência e os vínculos afetivos - tecnicamente chamamos de identificações - entre seus membros. Se estiver ausente um dos fatores, é possível que a comunidade se mantenha ainda pelo outro fator.

As idéias a que se faz o apelo só podem, naturalmente, ter importância se exprimirem afinidades importantes entre os membros, e pode-se perguntar quanta força essas idéias podem exercer. A história nos ensina que, em certa medida, elas foram eficazes. Por exemplo, a idéia do panhelenismo, o sentido de ser superior aos bárbaros de além-fronteiras; idéia que foi expressa com tanto vigor no conselho anfictiônico, nos oráculos e nos jogos, foi forte a ponto de mitigar os costumes guerreiros entre os gregos, embora, é claro, não suficientemente forte para evitar dissensões bélicas entre as diferentes partes da nação grega, ou mesmo para impedir uma cidade ou confederação de cidades de se aliar com o inimigo persa, a fim de obter vantagem contra algum rival.A identidade de sentimentos entre os cristãos, embora fosse poderosa, não conseguiu, à época do Renascimento, impedir os Estados Cristãos, tanto os grandes quanto os pequenos, de buscar o auxílio do sultão em suas guerras de uns contra os outros.

E atualmente, não existe idéia alguma que, espera-se, venha a exercer uma autoridade unificadora dessa espécie. Na realidade, é por demais evidente que os ideais nacionais, pelos quais as nações se regem nos dias de hoje, atuam em sentido oposto.

Algumas pessoas tendem a profetizar que não será possível pôr um fim à guerra, enquanto a forma comunista de pensar não tenha encontrado aceitação universal. Mas esse objetivo, em todo caso, está muito remoto, atualmente, e talvez só pudesse ser alcançado após as mais terríveis guerras civis. Assim sendo, presentemente, parece estar condenada ao fracasso a tentativa de substituir a força real pela força das idéias. Estaremos fazendo um cálculo errado, se desprezarmos o fato de que a lei, 
originalmente, era força bruta e que, mesmo hoje, não pode prescindir do apoio da violência.

Passo agora a acrescentar algumas observações aos seus comentários.

O senhor expressa surpresa ante o fato de ser tão fácil inflamar nos homens o entusiasmo pela guerra, e suspeita que algo, um instinto de ódio e de destruição, obra neles, facilitando essa excitação. Também nisto apenas posso exprimir meu inteiro acordo. Acreditamos na existência de um instinto dessa natureza, e durante os últimos anos temo-nos ocupado realmente em estudar suas manifestações.

Permita-me que me sirva dessa oportunidade para apresentar-lhe uma parte da teoria dos instintos que, depois de muitas tentativas hesitantes e muitas vacilações de opinião, foi formulada pelos que trabalham na área da psicanálise.

De acordo com nossa hipótese, os instintos humanos são de apenas dois tipos: aqueles que tendem a preservar e a unir, os quais denominamos eróticos, exatamente no mesmo sentido em que Platão usa a palavra Eros, em seu Symposium, ou sexuais, com uma deliberada ampliação da concepção popular de sexualidade; e aqueles que tendem a destruir e matar, os quais agrupamos como instinto agressivo ou destrutivo.

Como o senhor vê, isto não é senão uma formulação teórica da universalmente conhecida oposição entre amor e ódio, que talvez possa ter alguma relação básica com a polaridade entre atração e repulsão, que desempenha um papel na sua área de conhecimentos. Entretanto, não devemos ser demasiado apressados em introduzir juízos éticos de bem e de mal. Nenhum desses dois instintos é menos essencial do que o outro; os fenômenos da vida surgem da ação confluente ou mutuamente contrária de ambos.

Ora, é como se um instinto de um tipo dificilmente pudesse operar isolado; está sempre acompanhado ou, como dizemos, amalgamado por determinada quantidade do outro lado, que modifica o seu objetivo, ou, em determinados casos, possibilita a consecução desse objetivo. Assim, por exemplo, o instinto de autopreservação certamente é de natureza erótica; não obstante, deve ter à sua disposição a agressividade, para atingir seu propósito. 
Dessa forma, também o instinto de amor, quando dirigido a um objeto, necessita de alguma contribuição do instinto de domínio, para que obtenha a posse desse objeto. A dificuldade de isolar as duas espécies de instinto em suas manifestações reais, é, na verdade, o que até agora nos impedia de reconhecê-los.

Se o senhor quiser acompanhar-me um pouco mais, verá que as ações humanas estão sujeitas a uma outra complicação de natureza diferente. Muito raramente uma ação é obra de um impulso instintivo único (que deve estar composto de Eros e destrutividade). A fim de tornar possível uma ação, há de existir, via de regra, uma combinação desses motivos compostos.

Isto, há muito tempo, foi percebido por um especialista na sua matéria, o professor G. C. Lichtenberg, que ensinava física em Göttingen, durante o nosso classicismo, embora, talvez, ele fosse ainda mais notável como psicólogo do que como físico. Ele inventou uma bússola de motivos, pois escreveu: Os motivos que nos levam a fazer algo poderiam ser dispostos à maneira dos 32 rumos da rosa-dos-ventos e receber nomes de uma forma parecida: por exemplo, "pão-pão-fama. ou fama-famapão".De forma que,quando os seres humanos são incitados à guerra, podem ter toda uma gama de motivos para se deixarem levar uns nobres, outros vis, alguns francamente declarados, outros jamais mencionados. Não há por que enumerá-los todos. Entre eles está certamente o desejo da agressão e destruição: as incontáveis crueldades que encontramos na história e em nossa vida de todos os dias atestam a sua existência e a sua força. A satisfação desses impulsos destrutivos naturalmente é facilitada por sua mistura com outros motivos de natureza erótica e idealista.

Quando lemos sobre as atrocidades do passado, amiúde é como se os motivos idealistas servissem apenas de desculpa para os desejos destrutivos; e, às vezes, por exemplo, no caso das crueldades da Inquisição é como se os motivos idealistas tivessem assomado a um primeiro plano na consciência, enquanto os destrutivos lhes emprestassem um reforço inconsciente. Ambos podem ser verdadeiros.

Receio que eu possa estar abusando do seu interesse, que, afinal, se volta para a prevenção da guerra e não para nossas teorias. Gostaria, não obstante, de deter-me um pouco mais em nosso instinto destrutivo, cuja popularidade não é de modo algum igual à sua importância. 
Como consequiência de um pouco de especulação, pudemos supor que esse instinto está em atividade em toda criatura viva e procura levá-la ao aniquilamento, reduzir a vida à condição original de matéria inanimada. Portanto, merece, com toda seriedade, ser denominado instinto de morte, ao passo que os instintos eróticos representam o esforço de viver. $O$ instinto de morte torna-se instinto destrutivo quando, com o auxílio de órgãos especiais, é dirigido para fora, para objetos. $\mathbf{O}$ organismo preserva sua própria vida, por assim dizer, destruindo uma vida alheia. Uma parte do instinto de morte, contudo, continua atuante dentro do organismo, e temos procurado atribuir numerosos fenômenos normais e patológicos a essa internalização do instinto de destruição. Até cometemos a heresia de atribuir a origem de nossa consciência moral à essa orientação para dentro da agressão.Como o senhor adverte o fato desse processo adquirir magnitude excessiva é um motivo para nos preocuparmos.

Por outro lado, se essas forças se voltam para a destruição no mundo externo, o organismo se aliviará e o efeito deve ser benéfico. Isto serviria de justificação biológica para todos os impulsos condenáveis e perigosos contra os quais lutamos. Deve-se admitir que eles se situam mais perto da Natureza do que a nossa resistência, para a qual também é necessário encontrar uma explicação.

Talvez ao senhor possa parecer serem nossas teorias uma espécie de mitologia e, no presente caso, mitologia nada agradável. Todas as ciências, porém, não chegam, afinal, a uma espécie de mitologia como esta? Não se pode dizer o mesmo, atualmente, a respeito da sua física?

Para nosso propósito imediato, portanto, isto é tudo o que resulta daquilo que ficou dito: de nada vale tentar eliminar as inclinações agressivas dos homens. Segundo se nos conta, em determinadas regiões privilegiadas da Terra, onde a natureza provê em abundância tudo o que é necessário ao homem, existem povos cuja vida transcorre em meio à tranqüilidade, povos que não conhecem nem a coerção nem a agressão. Dificilmente posso acreditar nisso, e me agradaria saber mais a respeito de coisas tão afortunadas. Também os bolchevistas esperam ser capazes de fazer a agressividade humana desaparecer mediante a garantia de satisfação de todas as necessidades materiais e o estabelecimento da igualdade, em outros aspectos, entre todos os membros da comunidade. Isto, na minha opinião, é uma ilusão. Eles próprios, hoje em dia, estão armados da maneira mais cautelosa, e o método não menos importante que empregam 
para manter juntos os seus adeptos é o ódio contra qualquer pessoa além das suas fronteiras.

Em todo caso, como o senhor mesmo observou, não há maneira de eliminar totalmente os impulsos agressivos do homem; pode-se tentar desviá-los num grau tal que não necessitem encontrar expressão na guerra.

Nossa teoria mitológica dos instintos facilita-nos encontrar a fórmula para métodos indiretos de combater a guerra. Se o desejo de aderir à guerra é um efeito do instinto destrutivo, a recomendação mais evidente será contrapor-lhe o seu antagonista, Eros. Tudo o que favorece o estreitamento dos vínculos afetivos entre os homens deve atuar contra a guerra. Esses vínculos podem ser de dois tipos.

Em primeiro lugar, podem ser relações semelhantes àquelas relativas a um objeto amado, embora não tenham uma finalidade sexual. A psicanálise não tem motivo porque se envergonhar se nesse ponto fala de amor, pois a própria religião emprega as mesmas palavras : Ama a teu próximo como a ti mesmo.Isto, todavia, é mais facilmente dito do que praticado. O segundo vínculo afetivo é o que utiliza a identificação. Tudo o que leva os homens a compartilhar de interesses importantes produz essa comunhão de sentimento, essas identificações. E a estrutura da sociedade humana se baseia nelas, em grande escala.

Uma queixa que o senhor formulou acerca do abuso de autoridade leva-me a outra sugestão para o combate indireto à propensão à guerra. Um exemplo da desigualdade inata e irremovível dos homens é sua tendência a se classificarem em dois tipos, o dos líderes e o dos seguidores. Esses últimos constituem a vasta maioria; têm necessidade de uma autoridade que tome decisões por eles e à qual, na sua maioria devotam uma submissão ilimitada. Isto sugere que se deva dar mais atenção, do que até hoje se tem dado, à educação da camada superior dos homens dotados de mentalidade independente, não suscetível de intimidação e desejosa de manter-se fiel à verdade, cuja preocupação seja a de dirigir as massas dependentes.

É desnecessário dizer que as usurpações cometidas pelo poder executivo do Estado e a proibição estabelecida pela Igreja contra a liberdade de pensamento não são nada favoráveis à formação de uma classe desse tipo. A situação ideal, naturalmente, seria a comunidade humana que tivesse subordinado sua vida instintual ao domínio da razão. Nada mais poderia unir os homens de forma tão completa 
e firme, ainda que entre eles não houvesse vínculos emocionais. No entanto, com toda a probabilidade isto é uma expectativa utópica.

Não há dúvida de que os outros métodos indiretos de evitar a guerra são mais exequíveis, embora não prometam êxito imediato. Vale lembrar aquela imagem inquietante do moinho que mói tão devagar, que as pessoas podem morrer de fome antes de ele poder fornecer sua farinha.

O resultado, como o senhor vê, não é muito frutífero quando um teórico desinteressado é chamado a opinar sobre um problema prático urgente. É melhor a pessoa, em qualquer caso especial, dedicar-se a enfrentar o perigo com todos os meios à mão. Eu gostaria, porém, de discutir mais uma questão que o senhor não menciona em sua carta, a qual me interessa em especial.

Por que o senhor, eu e tantas outras pessoas nos revoltamos tão violentamente contra a guerra? Por que não a aceitamos como mais uma das muitas calamidades da vida? Afinal, parece ser coisa muito natural, parece ter uma base biológica e ser dificilmente evitável na prática.

Não há motivo para se surpreender com o fato de eu levantar essa questão. Para o propósito de uma investigação como esta, poder-se-ia, talvez, permitir-se usar uma máscara de suposto alheamento. A resposta à minha pergunta será a de que reagimos à guerra dessa maneira, porque toda pessoa tem o direito à sua própria vida, porque a guerra põe um término a vidas plenas de esperanças, porque conduz os homens individualmente a situações humilhantes, porque os compele, contra a sua vontade, a matar outros homens e porque destrói objetos materiais preciosos, produzidos pelo trabalho da humanidade.

Outras razões mais poderiam ser apresentadas, como a de que, na sua forma atual, a guerra já não é mais uma oportunidade de atingir os velhos ideais de heroísmo, e a de que, devido ao aperfeiçoamento dos instrumentos de destruição, uma guerra futura poderia envolver o extermínio de um dos antagonistas ou, quem sabe, de ambos.

Tudo isso é verdadeiro, e tão incontestavelmente verdadeiro, que não se pode senão sentir perplexidade ante o fato de a guerra ainda não ter sido unanimemente repudiada. Sem dúvida, é possível o debate em torno de alguns desses pontos. Pode-se indagar, se uma comunidade não deveria ter o direito de dispor da vida dos indivíduos; nem toda guerra é passível de condenação em igual medida; de vez que existem países 
e nações que estão preparados para a destruição impiedosa de outros, esses outros devem ser armados para a guerra. Mas não me deterei em nenhum desses aspectos; não constituem aquilo que o senhor deseja examinar comigo, e tenho em mente algo diverso.

Penso que a principal razão por que nos rebelamos contra a guerra é que não podemos fazer outra coisa. Somos pacifistas porque somos obrigados a sê-lo, por motivos orgânicos, básicos. E sendo assim, temos dificuldade em encontrar argumentos que justifiquem nossa atitude. Sem dúvida, isto exige alguma explicação.

Creio que se trata do seguinte.

Durante períodos de tempo incalculáveis, a humanidade tem passado por um processo de evolução cultural (sei que alguns preferem empregar o termo civilização.). É a esse processo que devemos o melhor daquilo em que nos tornamos, bem como uma boa parte daquilo de que padecemos. Embora suas causas e seus começos sejam obscuros e incertos, sua solução duvidosa, algumas de suas características são de fácil percepção. Talvez esse processo esteja levando à extinção a raça humana, pois, em mais de um sentido, ele inibe a função sexual; povos incultos e camadas atrasadas da população já se multiplicam mais rapidamente do que as camadas superiormente instruídas.

Talvez se possa comparar o processo à domesticação de determinadas espécies animais, e ele se acompanha, indubitavelmente, de modificações físicas; mas ainda não nos familiarizamos com a idéia de que a evolução da civilização é um processo orgânico dessa ordem.

As modificações psíquicas que acompanham o processo de civilização são notórias e inequívocas. Consistem num progressivo deslocamento dos fins instintivos e numa limitação imposta aos impulsos instintivos. Sensações que para os nossos ancestrais eram agradáveis, tornaram-se indiferentes ou até mesmo intoleráveis para nós; há motivos orgânicos para as modificações em nossos ideais éticos e estéticos.

Dentre as características psicológicas da civilização, duas aparecem como as mais importantes: o fortalecimento do intelecto, que está começando a governar a vida do instinto, e a internalização dos impulsos agressivos com todas as suas consequientes vantagens e perigos. 
Ora, a guerra constitui-se na mais óbvia oposição à atitude psíquica que nos foi incutida pelo processo de civilização, e, por esse motivo, não podemos evitar rebelarmo-nos contra ela; simplesmente não podemos mais nos conformar com ela. Isto não é apenas um repúdio intelectual e emocional. Nós, os pacifistas, temos uma intolerância constitucional à guerra, digamos, uma idiossincrasia exacerbada no mais alto grau.

Realmente, parece que o rebaixamento dos padrões estéticos na guerra desempenha um papel dificilmente menor em nossa revolta do que as suas crueldades.

E quanto tempo teremos de esperar até que o restante da humanidade também se torne pacifista? Não há como dizê-lo.

Mas pode não ser utópico esperar que esses dois fatores, a atitude cultural e o justificado medo das consequiências de uma guerra futura, venham a resultar, dentro de um tempo previsível, em que se ponha um término à ameaça de guerra. Por quais caminhos ou por que atalhos isto se realizará, não podemos adivinhar. Mas uma coisa podemos dizer : tudo o que estimula o crescimento da civilização trabalha simultaneamente contra a guerra.

Espero que o senhor me perdoe se o que eu disse o desapontou, e com a expressão de toda estima, subscrevo-me.

Cordialmente,

Sigmund Freud 


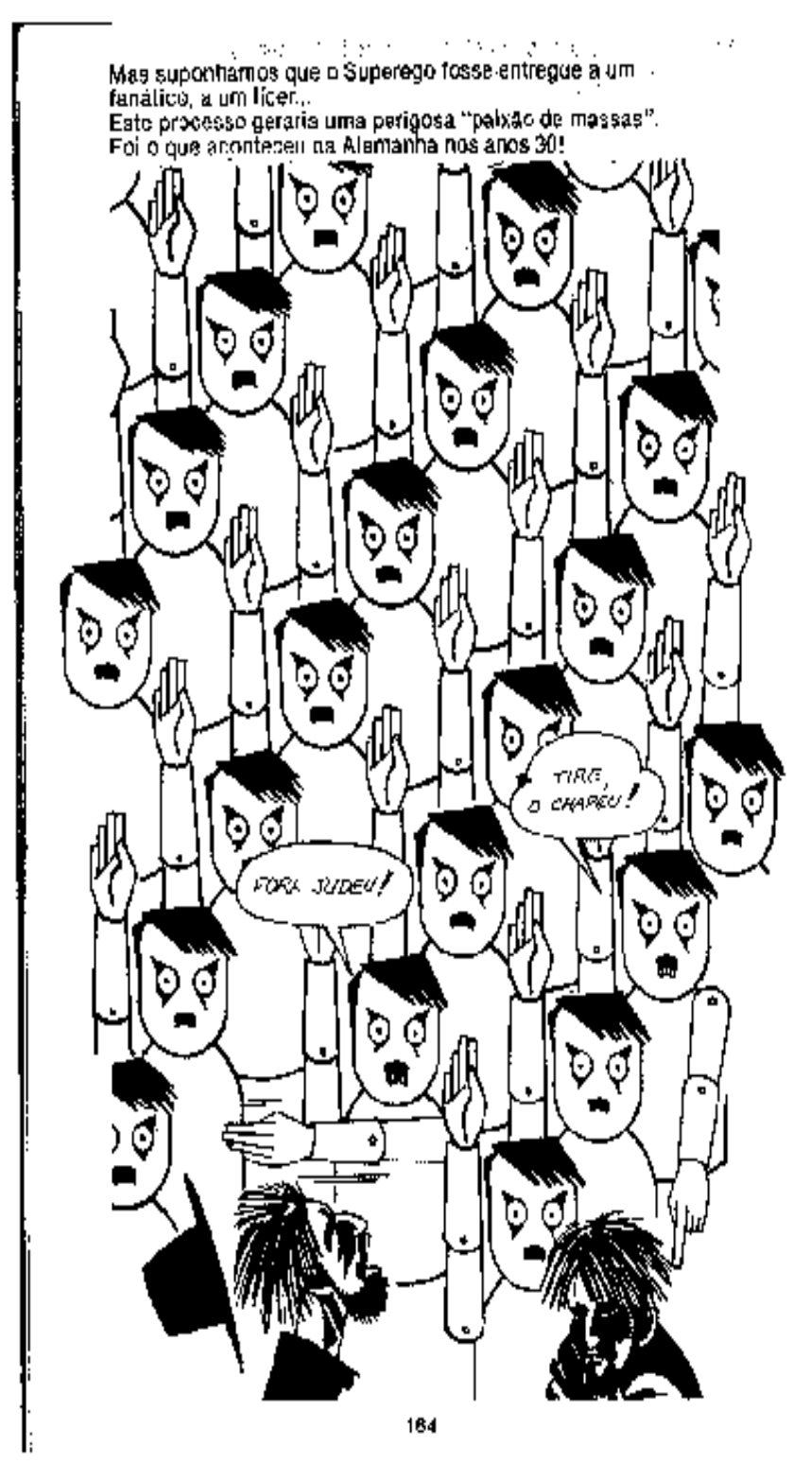




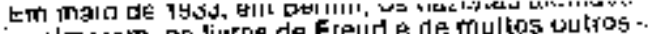

quelmararn os yros de Frevd e de multo

pensadotes mádernch.

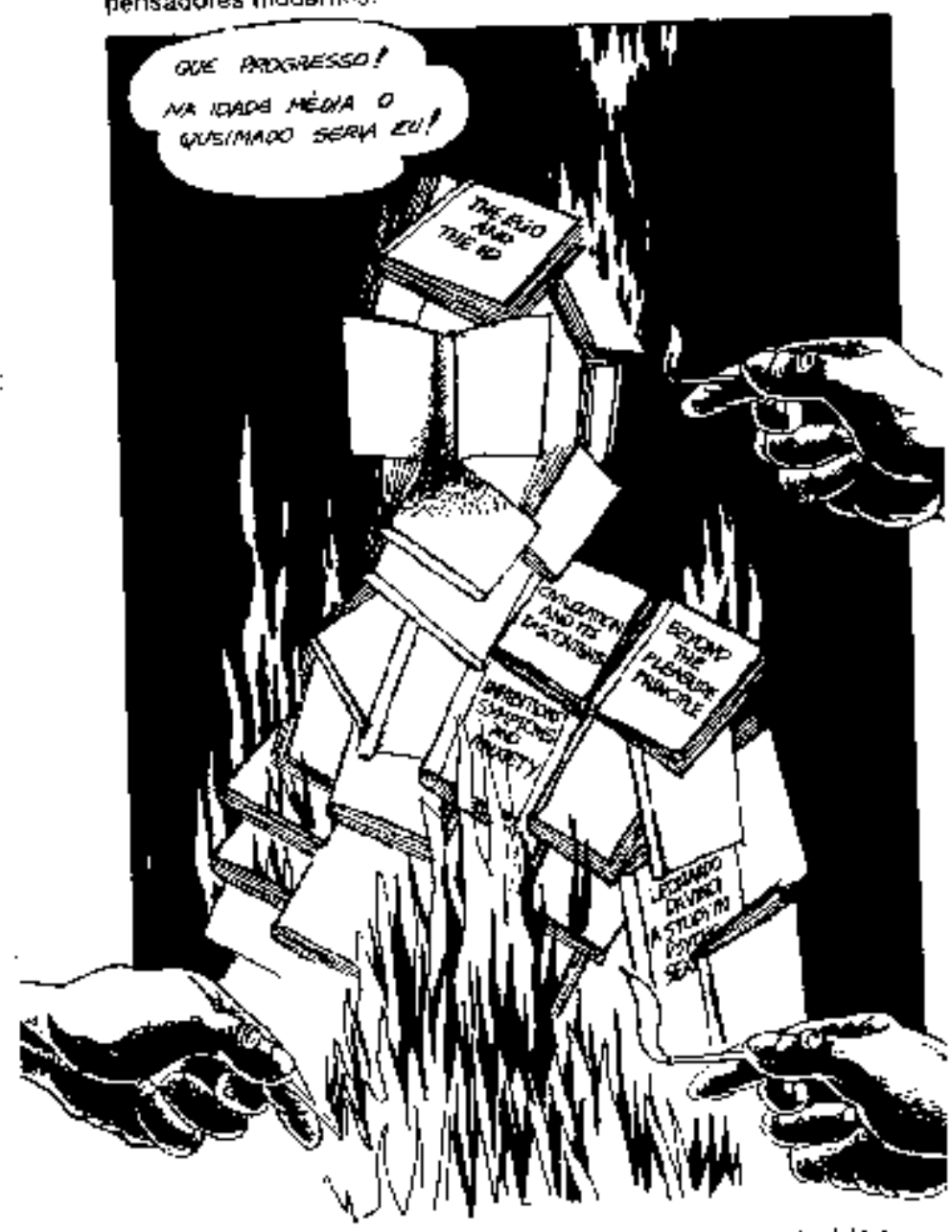

Freud so engalla! Os lis Freudse engalirat os outros judeus. entre elas as irmás de Fredd.

$$
135
$$


Marco de 1936: os nazistas irwadlram a Augtria. Os exldacos Mazls hes invadram a GAsa de Frewd para roubar obje:os de

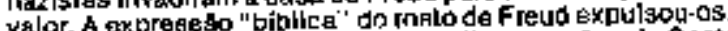

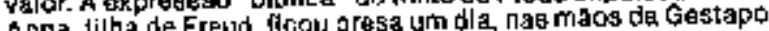

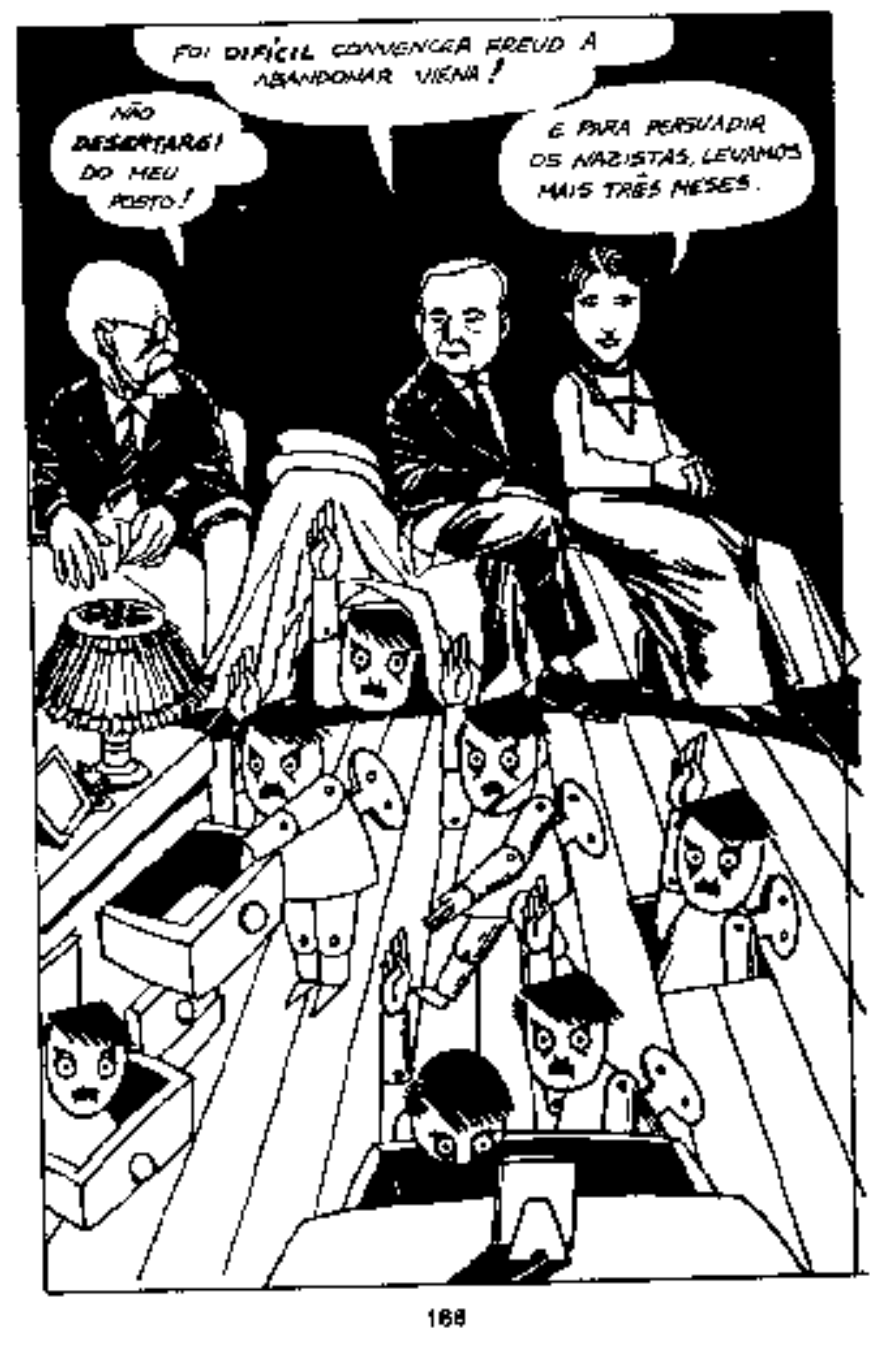


No mesmo mess, astil de 1923, Froud tol operadr de céncer no maxilar e 10 céd ua boca. Fol a prlmelra de 33 operaços:

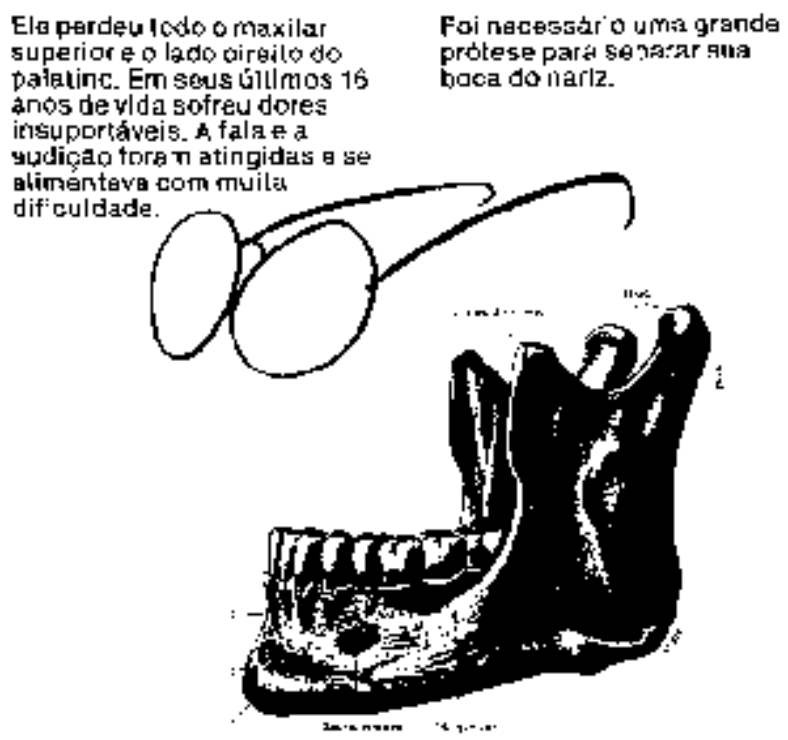

Anna. Gilha de Freud, cuidel: dfele ate a sua morte.

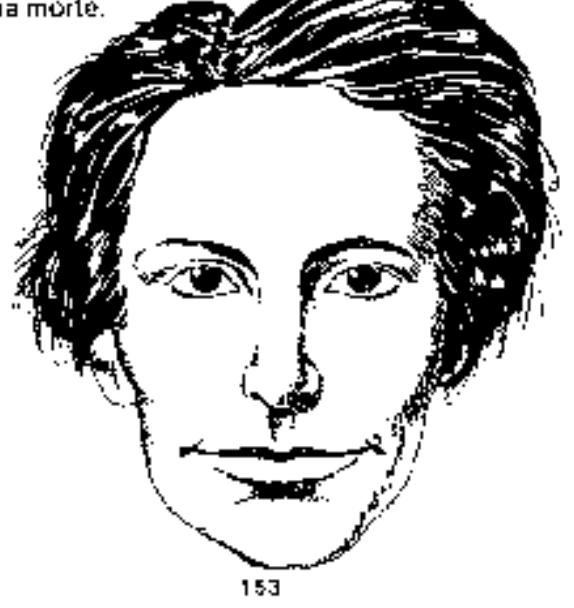




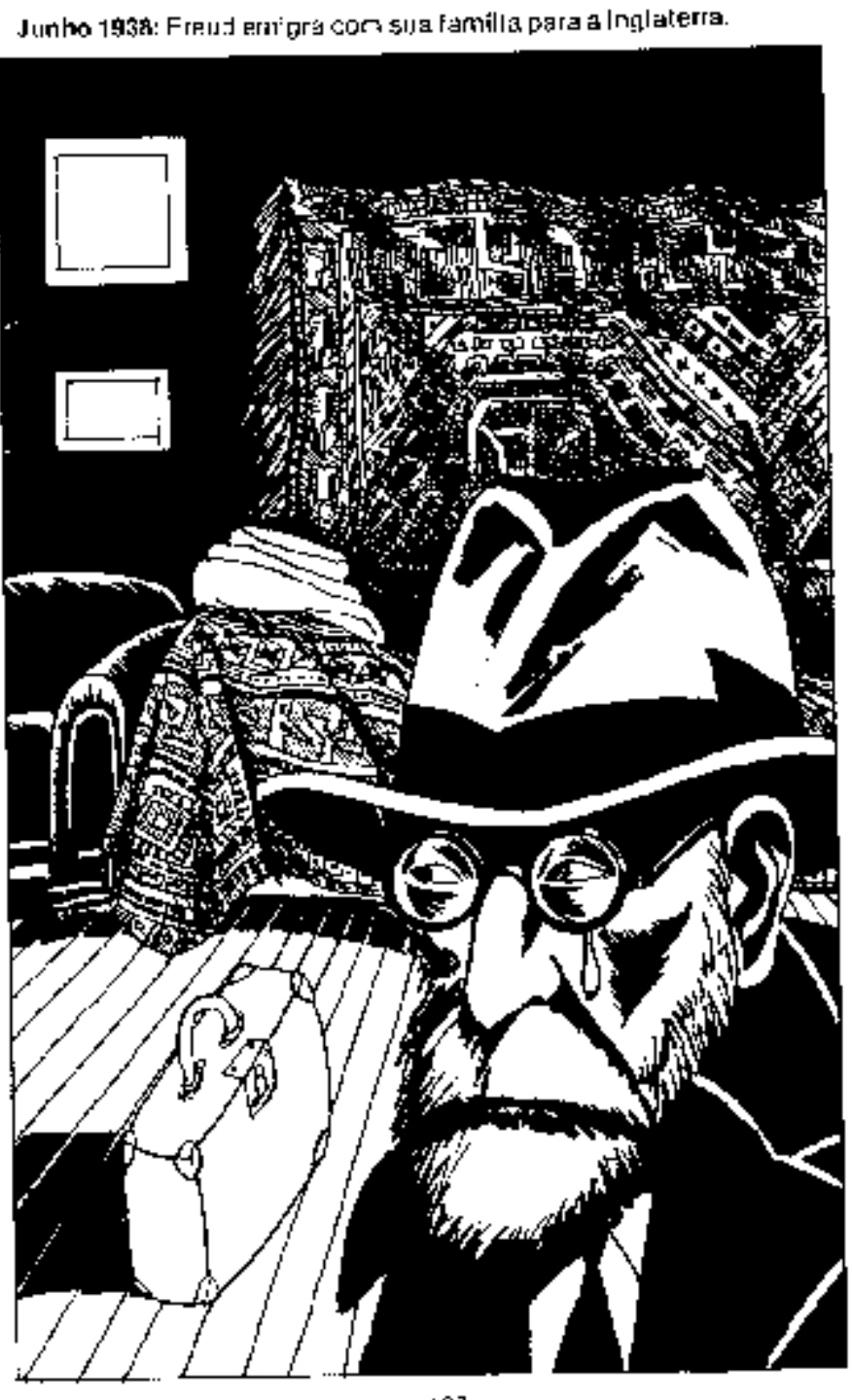

167 
Freud continuou trabalhando ate a sua morte, em 23 de seiembro d. 1939 .

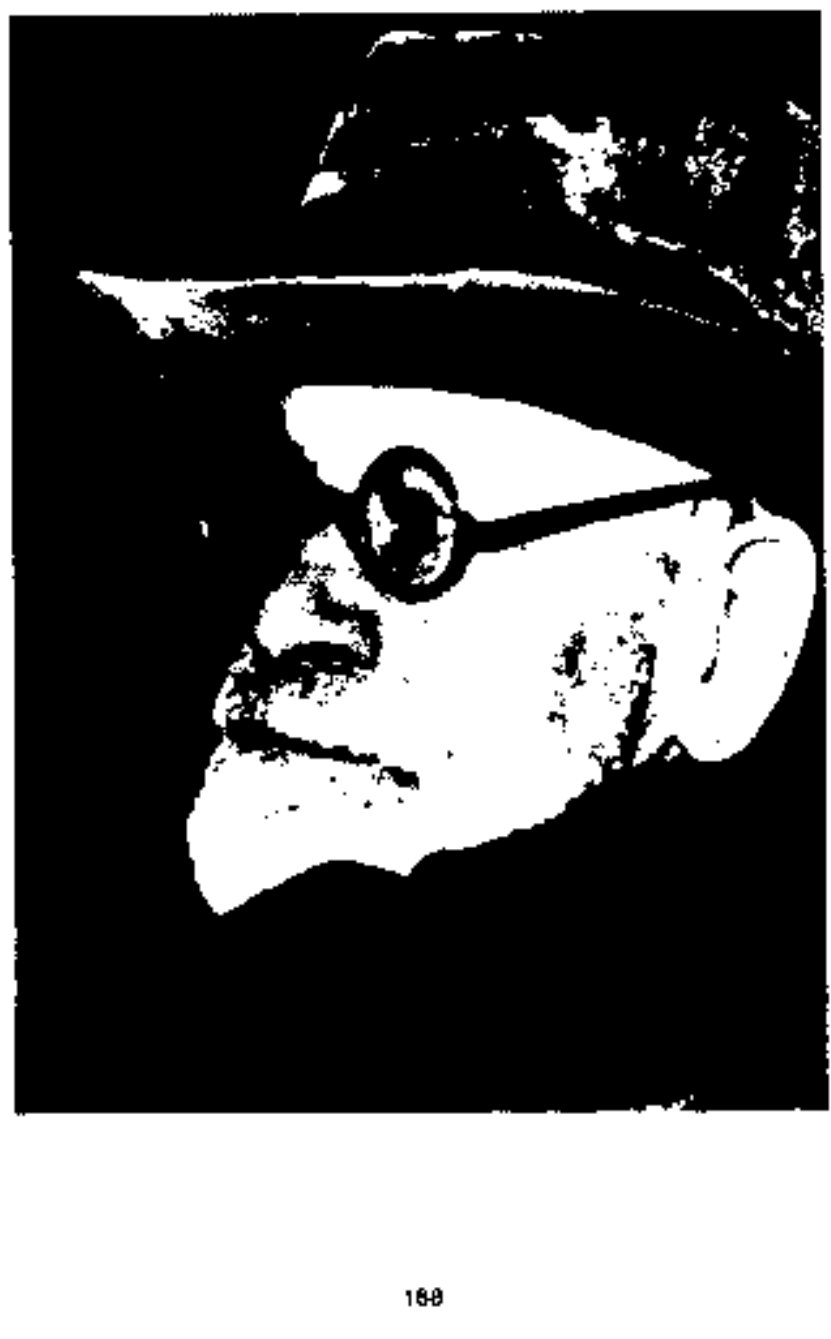




\section{1 - BIBLIOGRAFIA CIENTÍFICA-LITERÁRIA}

ALTO COMISSARIADO das NAÇÔES UNIDAS para OS DIREITOS HUMANOS. PERIÓDICO Da Divisão de Tratados de Direitos Humanos \#18 Out-Dez.2012. Entrevista com Eide Ridel (CDESC) sobre procedimentos de comunicações individuais. in http://www.ohchr.org/EN/HRBodies/HRTD\%20Newsletter/No.18,\%20October\%20to\%20December \%202012.pdf

AMARAL JÚNIOR, Alberto; PERRONE-MOISÉS, Cláudia (orgs). O Cinquentenário da Declaração Universal dos Direitos do Homem. São Paulo.Edusp.1999.

Curso de Direito Internacional Público, 3. Ed., São Paulo: Atlas, 2012.

APPIGNANESI, Richard(texto), ZARATE, Oscar (ilustração). Conheça Freud.Proposta Editorial Ltda, 1979, São Paulo

ARAUJO, Ruy Magalhães de. Expressões Jurídicas Latinas Aplicadas ao Cotidiano Forense.

ARAÚJO de, J.C.; COSTA de, M.A. A Margem - Estudos Uberlândia, MG, p.26-36, 2008

BANCO MUNDIAL. Overcoming Global Hunger. Washington.1993.

BANCO MUNDIAL. Pobreza e Fome: Problemas e Opções para a Segurança Alimentar em Países em Desenvolvimento. Washington, DC.1986

BUDA, Gotama. Loka Sutta (o Mundo). Udana III.10 in http://www.acessoaoinsight.net/sutta/udana.php

BUDA, Gotama. Dana Sutta (Generosidade). Itivuttaka 26 in http://www.acessoaoinsight.net/sutta/itivuttaka.php

CARVALHO de, A.M.P. Critérios Estruturantes para o ensino de ciências. São Paulo, Pioneira Thomsom Learning, 2004

CARUSO, F.; SILVEIRA,C. Quadrinhos para a cidadania. História, Ciências, Saúde - Manguinhos, Rio de Janeiro, v.16,n1,jan-mar,2009.

CHERN, Wu Jhy. I Ching, A Alquimia dos Números, Mauad X, 2009.

Committee on Food Security Information Note. http://www.fao.org/fileadmin/templates/cfs/Docs0910/InfoNote/CFS_General_Info_Note_EN.pdf

Comitê DESC, Observação Geral \#12. E/C.12/1999/5

COURTIS, Christian. The right to Food as a Justiciable Right: Challenges and Strategies. Max Planck Yearbook of United Nations Law, Volume 11, 2007.p.317-337.

Discurso do Santo Padre de abertura da Cúpula Mundial de Segurança Alimentar (2009) in http://www.vatican.va/holy_father/benedict_xvi/speeches/2009/november/documents/hf_benxvi_spe_20091116_fao_po.html 
Discurso da Alta Comissária para a celebração de primeiro aniversário da vigência do Protocolo Facultativo do Pacto Internacional de Direitos Econômicos, Sociais e Culturais. 9 abril de 2014. in http://www.ohchr.org/EN/NewsEvents/Pages/DisplayNews.aspx?NewsID=14493\&LangID=E

EINSTEIN, Albert; FREUD, Sigmund. O Por que da Guerra?

E/CN.4/2003/53 - Os Direitos Econômicos, Sociais e Culturais - Situação dos Pactos Internacionais de Direitos Humanos - Informe do sr. Hatem Kotrane, especialista independente encarregado de examinar a questão do projeto de protocolo facultativo do PIDESC. p.71

E/CN.4/2003/53 - Os Direitos Econômicos, Sociais e Culturais - Situação dos Pactos Internacionais de Direitos Humanos - Informe do sr. Hatem Kotrane, especialista independente encarregado de examinar a questão do projeto de protocolo facultativo do PIDESC.

EIDE, Asbjorn. E/CN.4/Sub.2/1999/12 - O direito a uma alimentação adequada e a não padecer de fome.Estudo atualizado sobre o direito à alimentação apresentado pelo sr. Asbjorn Eide em cumprimento da decisão 1998/106 da Subcomissão de Prevenção de Discriminações e Proteção da Minorias.

FAO, Diretrizes Voluntárias em Apoio à Realização Progressiva do Direito à uma Alimentação Adequada no Contexto de Segurança Alimentar Nacional.Roma, 2005.ISBN 978-92-5-305336-0.

FAO, 1997.Investindo em Segurança Alimentar.Roma.p.3

FAO, Cuaderno de Trabajo sobre el derecho a la alimentación 1. El derecho a la alimentación en el marco internacional de los derechos humanos y en las constituciones. 2013. p.1

FAO, Cuaderno de Trabajo sobre el derecho a la alimentación.Evaluación del derecho a la alimentación.2013.

FAO, Cuaderno de Trabajo sobre el derecho a la alimentación 9. Quien es quien en el derecho a la alimentación. 2013

FAO, Guide on Legislating for the Right to Food.2009

FAO, WFP and IFAD. 2012. The State of Food Insecurity in the World 2012.

Economic growth is necessary but not sufficient to accelerate reduction of hunger and malnutrition. Rome, FAO. ISBN 978-92-5-107316-2

HOUAISS, Antônio e VILLAR, Mauro de Salles, Minidicionário Houaiss da língua portuguesa - 2 ed. rev. e aum - Rio de Janeiro : Objetiva, 2004. ISBN 85-7302-623-5 (DHou)

KEYNES, John Maynard (1883-1946). As Consequências Econômicas da Paz(1919), tradução de Sérgio Bath; prefácio Marcelo de Paiva Abreu. São Paulo, Imprensa Oficial do Estado, Brasília, Editora Universidade de Brasília, 2002. Coleção Clássicos IPRI, v.3.

KUHN, T.S. A Estrutura das Revoluções Científicas. São Paulo, Perspectiva, 2003

LINSINGEN, L. Mangás e sua utilização pedagógica no ensino das ciências sob a perspectiva Ciência Tecnologia e Sociededa (CTS). Ciência \& Ensino, Campinas,v.1., número especial,p.1/9, novembro,2007 
LUYTEN, S.M.B. História em Quadrinhos. Um recurso de aprendizagem. Introdução; in História em Quadrinhos.Um recurso de aprendizagem. MELLO de Souza, M.C. (Orgs) Brasília:MEC, 2011

MARLEY, Bob, The Wailers. Natty Dread, 1974

MORSINK, Johannes, The Universal Declaration of Human Rights : Origins, Drafting and Intent, University of Pennsylvania Press, 1999. ISBN 08122-3474-X (cloth)

OLIVEIRA, Silvia Menicucci de. Direito ao Desenvolvimento: teorias e estratégias de implementação.USP, Sâo Paulo,2006.

PEDUZZI, L.O.Q.; KOHNLEIN, J.F.K. Sobre a Concepção Empirista-Indutivista no Ensino de Ciências. in VIII Encontro Nacional de Pesquisa em Ensino de Física, São Paulo, 5-8 Junho de 2002, p.18.

PEREIRA, Bruno Yepes, Curso de direito internacional público.

PERRONE-MOISÉS, Cláudia. Direito ao Desenvolvimento e Investimentos Estrangeiros. ed.Oliveira Mendes.1998.

POPPER, K.L. A Lógica da Pesquisa Científica. São Paulo, Cultrix, 2003.

PRAHLAD, Anand. Reggae Wisdom, Proverbs in Jamaican Music, 2001

RAMA,A; VERGUEIRO, W. Como usar as histórias em quadrinhos na sala de aula. São Paulo, Contexto, 2004.

REALE, Miguel. Teoria Tridimensional do Direito, situação atual, 5 ed. rev. e aum. - São Paulo: Saraiva, 1994.

SARAIVA, José Flávio Sombra. História das relações internacionais contemporâneas : da sociedade internacional do Século XIX à era da globalização, (Sombra organizador) São Paulo, Saraiva, 2008

SEITENFUS, Ricardo. Introdução ao direito internacional público

SHANIK,R.C. O que saber e como aprendê-lo. in As coisas são assim, BROCKMAN, J; MATSON, K. (Orgs), São Paulo, Cia das Letras, 2008

SHUE,Henry Basic Rights: Subsistence, Affluence, and U.S. Foreign Policy (Princeton, N.J.: Princeton University Press, 1980), 19 and 25.

TRAVASSOS, Lubélia. Kali Yuga e a Leis dos ciclos

VIGOTSKY, Lev Semenovich.1896-1934. A formação social da mente : do desenvolvimento dos processos psicológicos superiores.7ª̣ed - São Paulo: Martins Fontes, 2007. (Psicologia e Pedagogia) 
VILLAGRA, Soledad. Protocolo Facultativo ao PIDESC: uma ferramenta para exigir os DESC. Assunção.2008.INESC.Plataforma Dhesca Brasil ISBN-978 85-87386-20-5.

WITTMAN, Hannah. Food Sovereignty: reconnecting food, nature and community. ISBN 979-155266-374-5.p.20

ZIEGLER, Jean. The fight for the Right to Food: Lessons Learned, Palgrave Macmillan, 2011. ISBN:978-0-230-28464-7.p.4. Cf. G. Abi-Saab, 'Les sources du droit international: essai de déconstruction', In M. Rama-Montaldo, Liber Amicorum en hommage au Professeur Eduardo Jimenez de Aréchaga, Montevideo, Fundación de Cultura Universitaria, 1994, pp. 29-49

ZIEGLER, Jean. Destruição Massiva- Geopolítica da Fome. éditions du Seuil, Paris, 2011 